\title{
An Assessment of the Methods Used to Teach Content Skill Sets Required for the Introduction to Agriculture, Food, and Natural Resource Course
}

\author{
Lee I. Wright \\ liwright@mix.wvu.edu
}

Follow this and additional works at: https://researchrepository.wvu.edu/etd

Part of the Vocational Education Commons

\section{Recommended Citation \\ Wright, Lee I., "An Assessment of the Methods Used to Teach Content Skill Sets Required for the Introduction to Agriculture, Food, and Natural Resource Course" (2019). Graduate Theses, Dissertations, and Problem Reports. 3894. \\ https://researchrepository.wvu.edu/etd/3894}

This Thesis is protected by copyright and/or related rights. It has been brought to you by the The Research Repository @ WVU with permission from the rights-holder(s). You are free to use this Thesis in any way that is permitted by the copyright and related rights legislation that applies to your use. For other uses you must obtain permission from the rights-holder(s) directly, unless additional rights are indicated by a Creative Commons license in the record and/ or on the work itself. This Thesis has been accepted for inclusion in WVU Graduate Theses, Dissertations, and Problem Reports collection by an authorized administrator of The Research Repository @ WVU. For more information, please contact researchrepository@mail.wvu.edu. 
An Assessment of the Methods Used to Teach Content Skill Sets

Required for the Introduction to Agriculture, Food, and Natural Resource Course

\title{
Lee Wright
}

\author{
Thesis submitted to the \\ Davis College of Agriculture, Natural Resources, and Design \\ West Virginia University \\ in partial fulfillment of the requirements for the Degree of \\ Master of Science \\ in \\ Agricultural and Extension Education
}

Harry N. Boone, Jr., Ph.D., Chair

Deborah A. Boone, Ph.D.

Stacy A. Gartin, Ph.D.

School of Design and Community Development
Morgantown, West Virginia

2019

Key Words: Agricultural Education, Experiential Learning, Hands-on Learning, Supervised Agricultural Experience

Copyright 2019 Lee Wright 


\section{ABSTRACT \\ An Assessment of the Methods Used to Teach Content Skill Sets \\ Required for the Introduction to Agriculture, Food, and Natural Resource Course \\ Lee Wright}

Numerous studies have shown that students learn best when theory is applied to hands-on experiences. Traditionally, vocational agriculture, which evolved into agricultural education, has incorporated hands-on learning. For example, students typically raise livestock and crops as part of supervised agricultural experiences; learn to use chain saws, tractors, hay rakes, balers and other equipment found on farms; and basic metal working skills. They also sample soil and water to test for mineral levels and types of pollution that might affect agricultural practices. The purpose of this study, which incorporates a survey of agricultural education teachers in West Virginia, is to determine the extent to which those teachers incorporate experiential, i.e., hands-on, learning in an introductory level course. Thirty one of West Virginia's 104 agricultural education teachers responded to the survey, but 15 of those teacher's surveys could not be used because they do not teach Introduction to Agriculture. The results of the study concluded that hands-on learning is occurring in the Introduction to Agriculture, Food, and Natural Resource class. Of the respondents who taught the course, some did not teach all of the skill sets required for the course, which leads one to ask why. Each survey question permitted respondents to mark multiple ways in which he or she is teaching each skill, but further investigation is needed to discover why a surprising number of respondents marked "Do Not Teach" on skill sets and to discover more accurately how learning is occurring in the Introduction to Agriculture course. 


\section{DEDICATION}

I dedicate this work to my maternal grandfather, Wilford Chambers, who knew a great deal about hands-on learning and who allowed me to learn by letting me experience life on his 115-acre farm in Greene County, Pennsylvania. Working beside my grandfather, I learned about raising sheep and beef cattle. I learned about the hard work involved in running a dairy, "putting in" hay, and growing potatoes and corn. I learned to endure long hours for little profit and the struggle required during years when all odds seemed to be against us.

When my Grandpa Chambers reached the age that he was no longer able to live on his farm, he deeded it to me. After his death, I named it Chambers Farm in his honor. I earned a college degree, hoping for a teaching job that would allow me to earn a living and continue agricultural activities. After the school board for which I worked eliminated my first teaching position, I drove buses, tanker trucks, and construction equipment. On the last day of 2008, I met someone who became almost as big an influence in my life as my Grandpa Chambers had been. In time, he came to live with me on Chambers Farm and loved it as much as I. He persuaded me to return to college to earn a graduate degree. I earned an MBA, but the job for which I earned the degree did not materialize. I then earned a Master's Degree in Education. The Randolph County Board of Education hired me to teach agricultural education, a job I love; however, accepting a job in West Virginia meant selling Chambers Farm.

Completion of my thesis marks the end of my studies for a Master's Degree in Agricultural Education. I hope to earn a doctorate and to teach for many years. I now live 
on Chambers Farm West Virginia, where I can indulge my love for both teaching and agriculture. Grandpa Chambers would be proud. 


\section{ACKNOWLEDGEMENTS}

My life has changed greatly in the last ten years. First on my list of people to

thank is Dr. Harry N. Boone, Jr., my committee chair. Dr. Boone has hounded, scolded, cajoled, and encouraged me on the long road to this degree. He drove three hours to the school where I teach to be guest speaker at an annual FFA banquet, and he has sent emails on a regular basis to remind me to make time in my schedule to research and to write. He makes me learn; and for that, I am thankful.

Next, I thank my spouse, Dr. Lonnie Brewster. He is the person above all others who has encouraged me. He is my "prodder-in-chief" and the best proofreader anyone could want. He has no reservations about reading a passage I have written and pointing out its many flaws. He is also an effective teacher. He has sat beside me, coaching, explaining writing rules, and encouraging me as I have laboriously written many assignments.

I am thankful for my friend and professor, the late Patricia Obenauf, who taught me to deal with stress by becoming a more spiritual person and who instilled in me the concepts of the multiple ways in which we learn. I miss her calm demeanor, her quiet smile, her warm hugs, and her consistent words of encouragement. I am also grateful to Dr. Ron Iannone, a professor who actually helped me understand philosophy. Like Pat, he was encouraging as I struggled to work full time and finish my second master's degree. Without my experiences in his classes, I would never have attempted another degree. 
Last, I acknowledge my mother, Cherry Chambers-Wright-Ellsworth. With the death of her mother, my mother had to assume many family and farm duties at a young age. She taught me perseverance, the value of hard work, and love for the land, which sustains us. 


\section{TABLE OF CONTENTS}

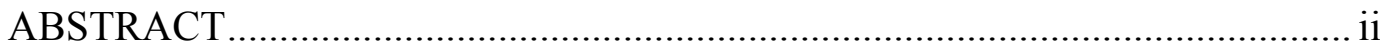

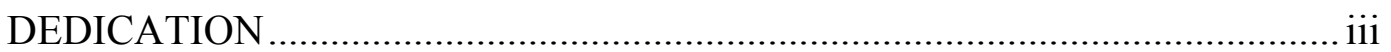

ACKNOWLEDGEMENTS ..................................................................

LIST OF TABLES ................................................................................... xii

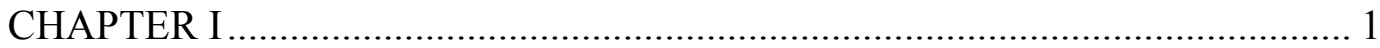

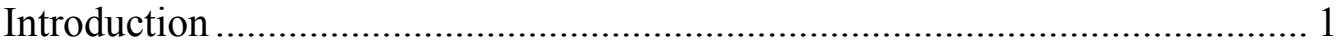

Rationale for Experiential Learning in Agricultural Education: .................... 1

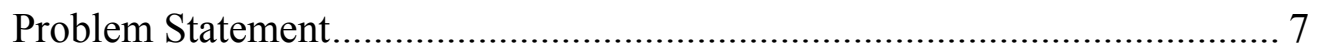

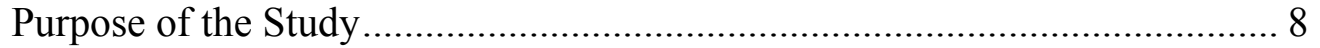

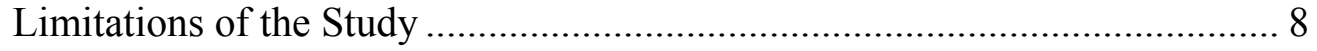

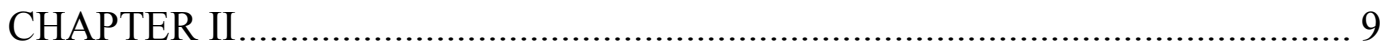

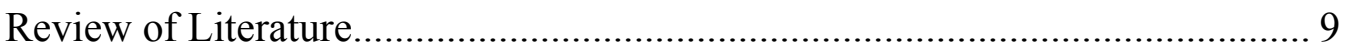

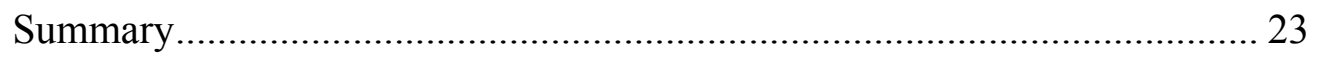

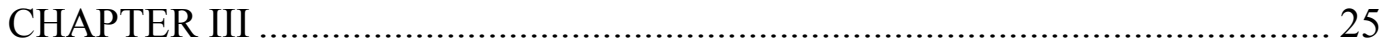

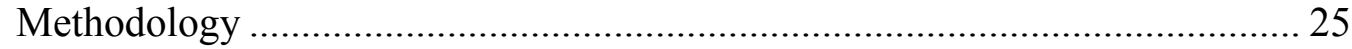

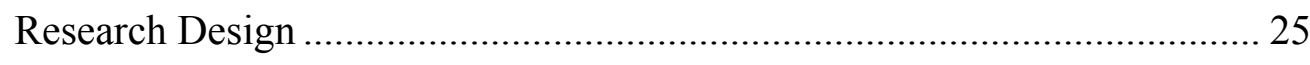

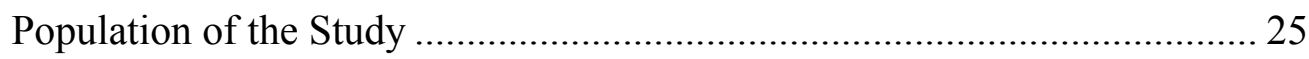

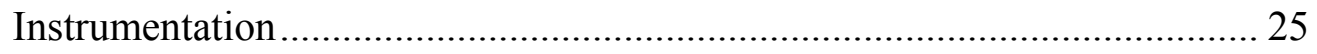

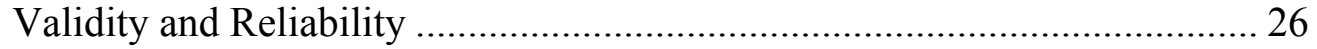

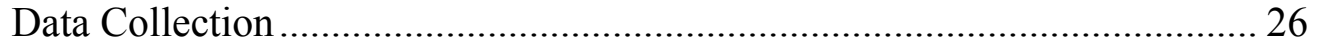

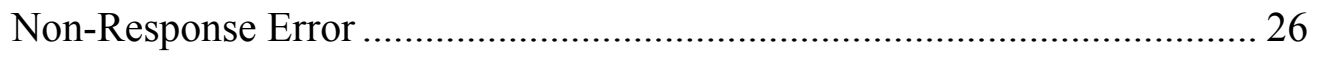

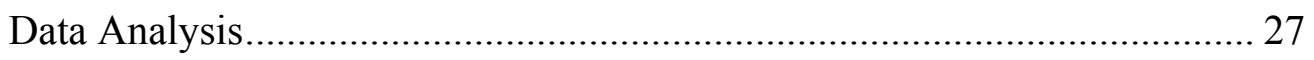

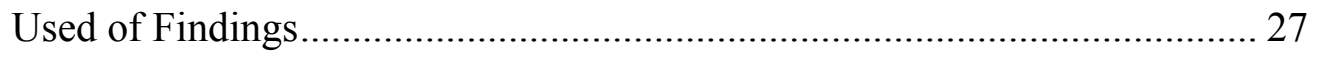

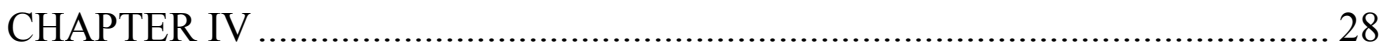

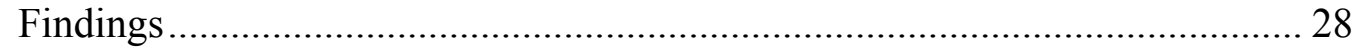

Demographic Characteristics of Respondents ...................................... 28

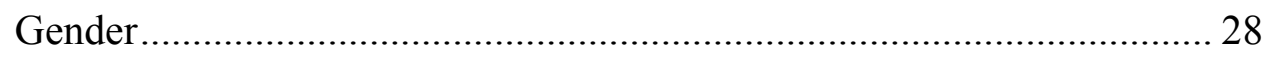

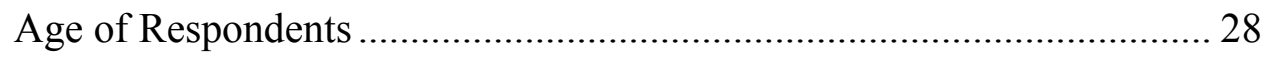

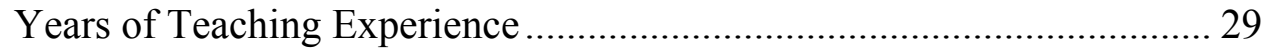

Level of Education of Respondents ...................................................... 30 
Methods Used to Teach Introduction to Agriculture, Food and Natural

Resources.

Basic Finance - Personal Inventory, Net Worth, Income, and Expense .. 31

Create a Plan for Their Own Agricultural Enterprise............................... 33

Create an Advertisement for an Agricultural Product. .............................. 34

Methods of Marketing Agricultural Commodities, Products, and Services in the Domestic and International Markets................................................ 36

Researching Local Supply and Demand of Agricultural Products........... 37

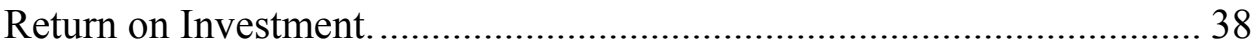

Supervised Agricultural Experience (SAE)............................................... 40

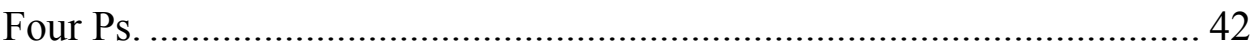

Types of Agribusiness Ownership.......................................................... 43

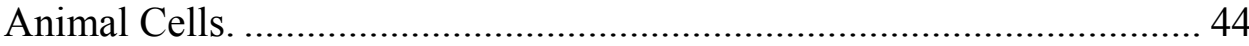

Animal Health Disorders. ........................................................................ 46

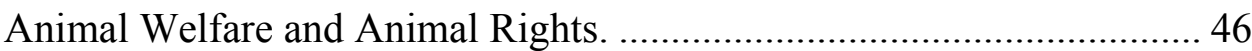

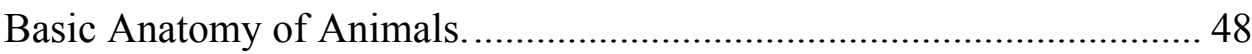

Bio-Security in The Animal Industry. ..................................................... 50

Breeds of Livestock. …………………................................................ 51

Common and Scientific Names of Major Animal Species....................... 52

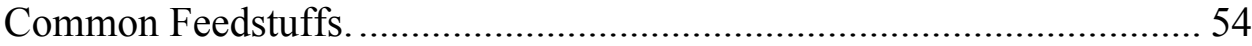

Issues of Animal Welfare and Animal Rights. .......................................... 54

Diagram the Typical Animal Cell........................................................... 56

Effects of Animal Agriculture on the Environment................................... 58

Facilities Needed to House and Produce Animal Species Safely and

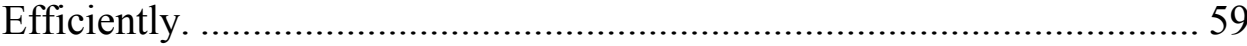

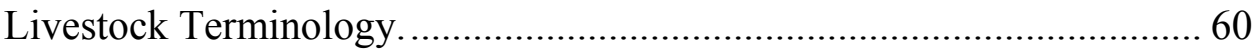

Perform a Basic Health Exam on a Live Animal...................................... 62

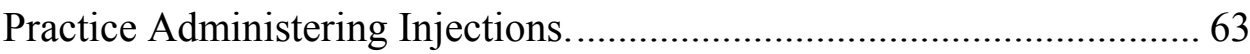

Origin, Significance, Distribution and Domestication of Animals............ 64

Agricultural Innovations in Agricultural Biotechnology ............................ 66

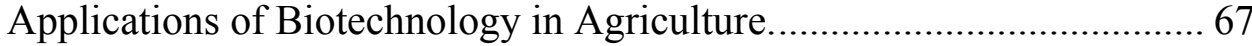

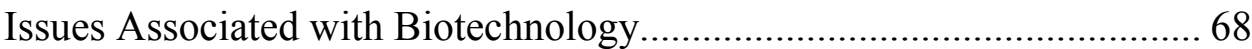

Current Agricultural Products Impacted by Biotechnology Practices...... 70 


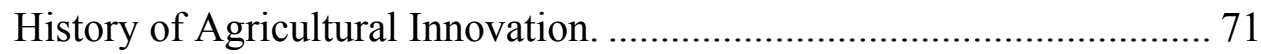

Major Agriculture Inventions and Their Impact on the Industry.............. 73

Agricultural Related Technology and Equipment. ..................................... 74

Common Weights and Measures Used in the Food Products and

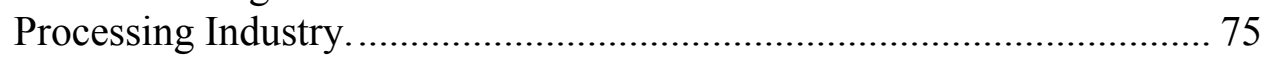

Compare and Contrast Various Food Labels.............................................. 77

Conducting a Food Preservation Experiment. ......................................... 78

Foods Derived from Meat, Egg, Poultry, Fish, and Dairy Products......... 80

Methods of Food Preservations. ............................................................... 81

Produce a Food Product Such As Cheese, Sausage, or Sauerkraut.......... 83

Products Derived From Fruits and Vegetables.......................................... 84

Products Derived From Grains, Legumes, and Oilseeds.......................... 86

Quality and Yield Grades of Food Products........................................... 87

History of the Animal Processing Industry................................................ 89

Importance of Food Labeling to the Consumer. ........................................ 90

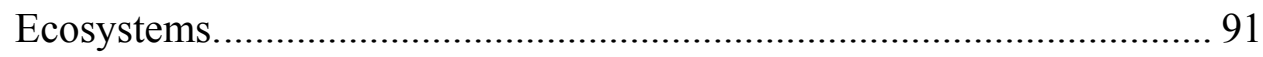

Identify Alternative Energy Sources..................................................... 93

Identify Healthy Ecosystem Characteristics............................................ 94

Identify Nonrenewable Resources........................................................ 95

Identify Renewable Resources................................................................. 97

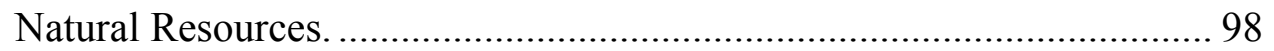

Nonrenewable Resources.................................................................. 99

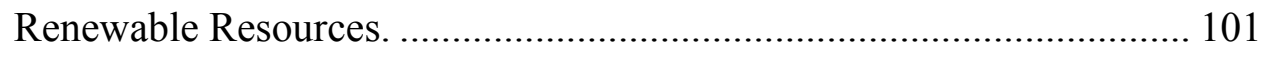

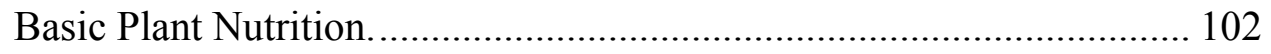

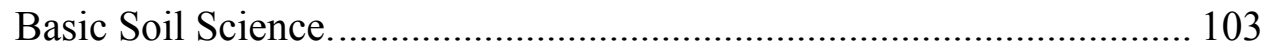

Conduct Soil Sampling and Testing. .................................................... 105

Diagram a Typical Plant Cell and Identify Cell Organelles and Their

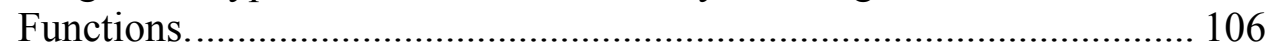

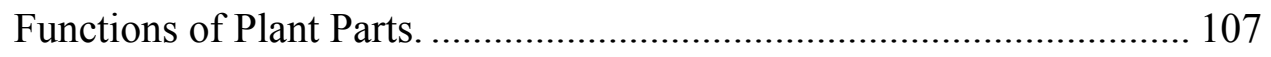

Identify Agriculturally Important Plants by Common Names................. 109

Identify The Components and Functions of Plant Roots......................... 110

Components and Functions of Plant Flowers. ...................................... 112

Components and Functions of Plant Leaves.......................................... 113 
Identify the Components and Functions of Plant Stems..................... 115

Interpret Soil Results to Determine Fertilizer Application Needs......... 116

Parts of a Plant. .......................................................................... 118

Plant Physiology - Photosynthesis, Reproduction, Respiration, and

Transpiration. .............................................................................. 119

Teach Adding, Subtracting, Multiplying, and Dividing Decimals........ 120

Adding, Subtracting, Multiplying, and Dividing Fractions. ................. 122

Adding, Subtracting, Multiplying, and Dividing Whole Numbers........ 123

Basic Math Practices Used in the Power, Structural, and Technical

Systems. ................................................................................. 125

Construct a Project Using Hand Tools............................................... 127

Convert Decimals to Percentages and Percentages to Decimals........... 128

Convert Fractions to Decimals and Decimals to Fractions.................... 130

Proper and Safe Used of Hand Tools.................................................... 131

Basic Hand Tools and Their Proper Use in an Agricultural Setting...... 132

Units of Weight, Volume, and Temperature........................................ 134

Use of a Ruler, a Metric Ruler, and a Measuring Tape to Measure. ..... 135

Recite the FFA Creed.................................................................. 137

Recite the FFA Motto. .................................................................. 138

Research the Important Dates and Events in the History of FFA and Agricultural Education.................................................................. 140

Demonstrate Knowledge of FFA History, Code of Ethics, and Official Dress.

Percentage of Teachers Using Various Teaching Strategies ..................... 142

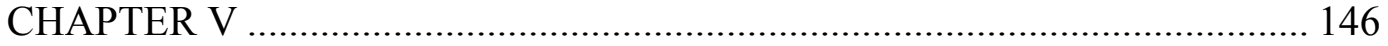

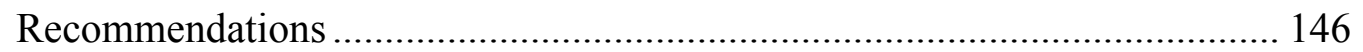

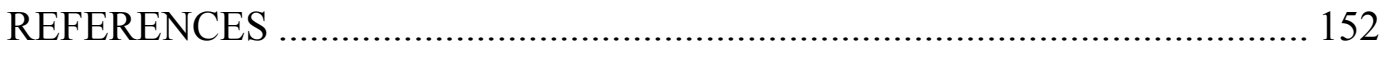

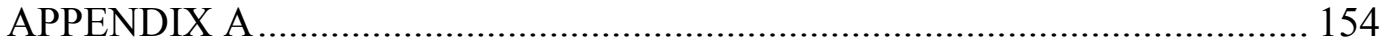

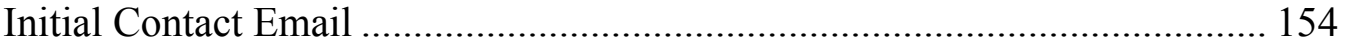

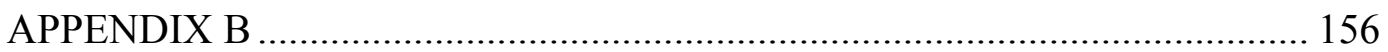

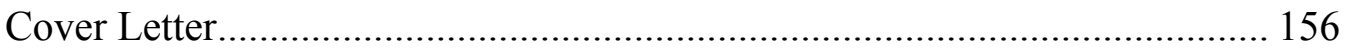

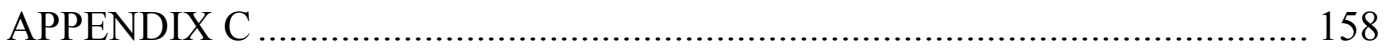

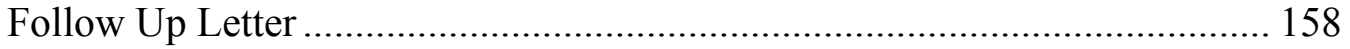

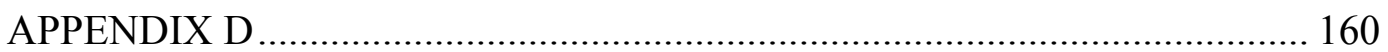




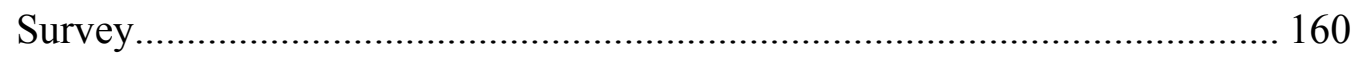

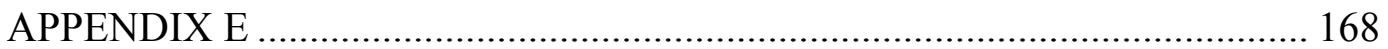

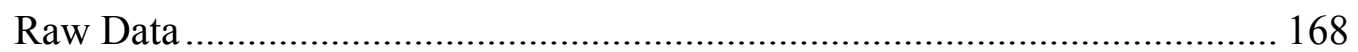

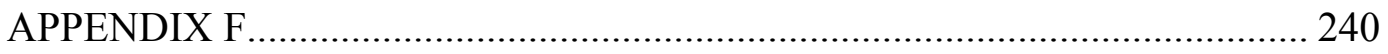

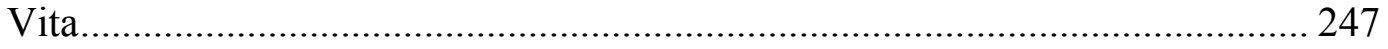




\section{LIST OF TABLES}

1 Gender of Respondents and Teaching of Introduction to Agriculture, Food, and Natural Resources

2 Age of Respondents Compared to Teaching the Introduction to Agriculture, Food and Natural Resources (WVEIS 0101) Course ……………………….......29

3 Years of Teaching Experience Compared to Teaching the Introduction to Agriculture, Food and Natural Resources (WVEIS 0101) Course ........................30

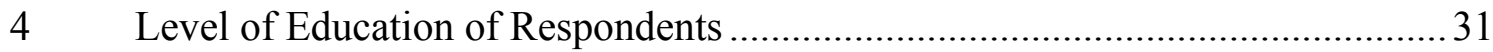

$5 \quad$ Methods Used to Teach Agribusiness CSS: Basic Finance - Personal Inventory, Net Worth, Income, Expenses............................................................ 32

6 Methods Used to Teach Agribusiness CSS: Create a Plan for Their Own

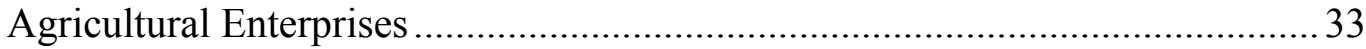

7 Methods Used to Teach Agribusiness CSS: Create an Advertisement for an

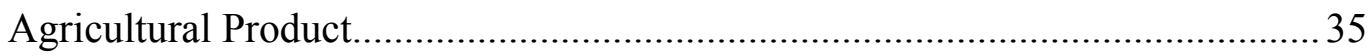

8 Methods Used to Teach Agribusiness CSS: Methods of Marketing Agricultural Commodities, Products, Services in Domestic and International Markets

9 Methods Used to Teach Agribusiness CSS: Research Local Supply and Demand of Agricultural Products .......................................................................... 39

10 Methods Used to Teach Agribusiness CSS: Return on Investment.....................40

11 Methods Used to Teach Agribusiness CSS: Supervised Agricultural Experience (SAE)

12 Methods Used to Teach Agribusiness CSS: The Four Ps (product, place, price, and promotion).

13 Methods Used to Teach Agribusiness CSS: Types of Agribusiness Ownership 44

14 Methods Used to Teach Animal Systems CSS: Animal Cells.............................45

15 Methods Used to Teach Animal Systems CSS: Animal Health Disorders

16 Methods Used to Teach Animal Systems CSS: Animal Welfare and Animal rights 48

17 Methods Used to Teach Animal Systems CSS: Basic Anatomy of Animals

18 Methods Used to Teach Animal Systems CSS: Bio-security in the Animal Industry 50

19 Methods Used to Teach Animal Systems CSS: Breeds of Livestock .52

20 Methods Used to Teach Animal Systems CSS: Common and Scientific Names of Major Animal Species. 
21 Methods Used to Teach Animal Systems CSS: Common Types of

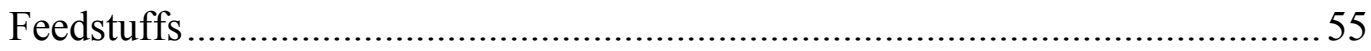

22 Methods Used to Teach Animal Systems CSS: Debate the Issues Associated with Animal Welfare and Animal Rights .........................................................56

23 Methods Used to Teach Animal Systems CSS: Diagram a Typical Animal Cell and Identify the Organelles.

24 Methods of Teaching Animal Systems CSS: Effects of Animal Agriculture on the Environment

25 Methods Used to Teach Animal Systems CSS: Facilities Needed to House and Produce Animal Species Safely and Efficiently .............................................6 60

26 Methods Used to Teach Animal Systems CSS: Livestock Terminology

27 Methods Used to Teach Animal Systems CSS: Perform a Basic Health Exam on a Live Animal

28 Methods Used to Teach Animal Systems CSS: Practice Administering Injections

29 Methods Used to Teach Animal Systems CSS: The Origin, Significance, distribution, and domestication of animals

30 Methods Used to Teach Agriculture Innovations: Agricultural

Biotechnology

31 Methods Used to Teach Agricultural Innovations: Applications of Biotechnology in Agriculture

32 Methods Used to Teach Agricultural Innovations CSS: Debate the Issues Associated with Biotechnology .....

33 Methods Used to Teach Agricultural Innovations CSS: Research Current Agricultural Products Impacted by Biotechnology Practices ..... 70

34 Methods Used to Teach Agricultural Innovations CSS: The History of Agriculture Innovation.

35 Methods Used to Teach Agriculture Innovations CSS: The Major Agriculture Inventions and Their Impact on the Industry

36 Methods Used to Teach Agriculture Innovations CSS: Used Agricultural Related Technology and Equipment.

37 Methods Used to Teach Food Products and Processing CSS: Common Weights and Measures in the Food Products and Processing Industry 76

38 Methods Used to Teach Food Products and Processing CSS: Compare and Contrast Various Food Labels

39 Methods Used to Teach Food Products and Processing CSS: Conduct a Food Preservation Experiment. 
40 Methods Used to Teach Food Products and Processing CSS: Foods Derived from Meat. Egg, Poultry, Fish and Dairy Products........................................... 81

41 Methods Used to Teach Food Products and Processing CSS: Methods of Food Preservation

42 Methods Used to Teach Food Products and Processing CSS: Produce a Food Product (cheese, sausage, sauerkraut, etc.)

43 Methods Used to Teach Food Products and Processing CSS: Products

Derived from Fruits and Vegetables

44 Methods Used to Teach Food Products and Processing CSS: Products

Derived from Grains, Legumes, and Oilseeds

45 Methods Used to Teach Food Products and Processing CSS: Quality and Yield Grades of Food Products.

46 Methods Used to Teach Food Products and Processing CSS: The History of the Animal Processing Industry....

47 Methods Used to Teach Food Products and Processing: The Importance of Food Labeling to the Consumer............................................................................. 91

48 Methods Used to Teach Natural Resource CSS: Ecosystems .92

49 Methods Used to Natural Resources CSS: Identify Alternative Energy Sources

50 Methods Used to Teach Natural Resource CSS: Identify Healthy Ecosystem Characteristics.

51 Methods Used to Teach Natural Resource CSS: Identify Nonrenewable Resources .96

52 Methods Used to Teach Natural Resource CSS: Identify Renewable Resources

53 Methods Used to Teach Natural Resource CSS: Natural Resources....

54 Methods Used to Teach Natural Resource CSS: Nonrenewable Resources

Methods Used to Teach Natural Resource CSS: Renewable Resources

Methods Used to Teach Plant Systems CSS: Basic Plant Nutrition....

Methods Used to Teach Plant Systems CSS: Basic Soil Science.

58 Methods Used to Teach Plant Systems CSS: Conduct Soil Sampling and Testing.

59 Methods Used to Teach Plant Systems CSS: Diagram a Typical Plant Cell and Identify Cell Organelles and their Functions

60 Methods Used to Teach Plant Systems CSS: Functions of Plant Parts 108 
61 Methods Used to Teach Plant Systems CSS: Identify Agriculturally Important Plants by Common Names

62 Methods Used to Teach Plant System CSS: Identify the Components and Functions of Plant Roots

63 Methods Used to Teach Plant Systems CSS: Identify the Components and the Functions of Plant Flowers

64 Methods Used to Teach Plant System CSS: Identify the Components and the Functions of Plant Leaves

65 Methods Used to Teach Plant System CSS: Identify the Components and the Functions of Plant Stems

66 Methods Used to Teach Plant System CSS: Interpret Soil Results to Determine Fertilizer Application Needs

67 Methods Used to Teach Plant System CSS: Parts of a Plant

68 Methods Used to Teach Plant System CSS: Plant Physiology Photosynthesis, Reproduction, Respiration, and Transpiration .....

69 Methods Used to Teach Power, Structural, and Technical CSS: Add, Subtract, Multiply, and Divide Decimals, with and without a Calculator

70 Methods Used to Teach Power, Structural, and Technical CSS: Add, Subtract, Multiply, and Divide Fractions

71 Methods Used to Teach Power. Structural and Technical CSS: Add, Subtract, Multiply, and Divide Whole Numbers, with and without a Calculator 124

72 Methods Used to Teach Power, Structural, and Technical CSS: Basic Math Practices used in Power, Structural, and Technical Systems...

73 Methods Used to Teach Power, Structural, and Technical CSS: Construct a Project Using Hand Tools

74 Methods Used to Teach Power, Structural, and Technical CSS: Convert Decimals to Percentages and Percentages to Decimals.

75 Methods Used to Teach Power, Structural, and Technical CSS: Convert Fractions to Decimals and Decimals to Fractions.

76 Methods Used to Teach Power, Structural, and Technical CSS: Properly and Safely Used Hand Tools

77 Methods Used to Teach Power, Structural, and Technical CSS: The Basic Hand Tools and their Proper Used in an Agricultural Setting....

78 Methods Used to Teach Power, Structural, and Technical CSS: Units of Weight, Volume, and Temperature 
79 Methods Used to Teach Power, Structural, and Technical CSS: Used a Ruler, a Metric Ruler, and a Measuring Tape to Measure.................................... 136

80 Methods Used to Teach Leadership CSS: Recite the FFA Creed ...................... 138

81 Methods Used to Teach Leadership CSS: Recite the FFA Moto …………........ 139

82 Methods Used to Teach Leadership CSS: Research the Important Dates and Events in the History of FFA and Agricultural Education ................................. 140

83 Methods Used to Teach Leadership CSS: Students will Demonstrate Knowledge of FFA History, Code of Ethics, and Official Dress. 142

84 Percentage of Teachers Using Various Teaching Strategies Across All CSSs . 145 


\section{CHAPTER I}

\section{Introduction}

Informal discussions with agricultural education students at local, regional, state, and national events seem to indicate that many students desire hands-on learning experiences as part of their agricultural education courses. Informal discussions with agricultural education teachers seem to indicate that the number of hands-on experiences differ widely from teacher to teacher, with some focusing primarily on bookwork and theory. Others incorporate only the supervised agricultural experience (SAE) as part of the agricultural education courses. Some incorporate a significant amount of hands-on experience by engaging students in shop projects; repair and maintenance of agricultural equipment; production of greenhouse, raised beds, and field produce; involvement in aquaponics; and a myriad of other types of hands-on experiences. Now, as in the past, the degree to which students are involved in agricultural experiences beyond the traditional classroom setting, seems to vary, despite the fact that opportunities to engage students in hands-on agricultural experiences have been available to teachers for well over one hundred years.

\section{Rationale for Experiential Learning in Agricultural Education:}

The Congressional District Schools were the forerunners of government supported vocational agriculture schools. These schools included both elementary and secondary schools. "Between 1901 and 1905, 33 public high schools included agriculture in their curriculum" (Hillison, 1989, p. 7). "By 1915, 4,665 public high schools and 253 private high schools incorporated agriculture as a part of their curricular offerings" (Hillison, 1989, p.7). The facilities at these schools were usually a main building, 
dormitories, laboratories, and a school farm. There was an emphasis on hands-on learning through the late $19^{\text {th }}$ century and early $20^{\text {th }}$ century. For example, "Alabama school students were given laboratory work in soils, farm crops, and horticulture" (Hillison, 1989, p.8). "The thirty-ninth annual report [of the U.S. Department of Education] 1917 reported that only about one-fifth of study and recitation time was spent on agricultural topics; in reality, the course work was broad-based, crossing several disciplines and competencies" (Hillison, 1989, p.10). The curriculum for the agricultural schools consisted of four years of education in the following areas: English, mathematics, history, science, agriculture, and farm mechanics. "The farm mechanics laboratory had instruction, for boys, in free-hand drawing, wood working, forge work, mechanical drawing, and elementary surveying" (Hillison, 1995, p. 11).

The Smith-Hughes Act of 1917 emphasized the importance of agricultural education and stipulated the following purposes:

1. To provide for the promotion of vocational education,

2. To provide for cooperation with the states in the promotion of vocational education in agriculture and industry,

3. To provide for cooperation with the states in the preparation of teachers of vocational education,

4. To appropriate money and regulate its expenditures

(Early Congressional Efforts, an Early Philosophy of Agricultural Education, 2016 p. 1).

The act became law to provide an education to students for employment on a farm or in a farm home. The education strategies centered on problem solving instruction and 
hands-on learning. Students today also need the hands-on experiences to help them decide on a career or to prepare for further training at a technical school or college (Early Congressional Efforts, an Early Philosophy of Agricultural Education, 2016).

Research has established a link between experiential instruction strategies and improvement in science skills. Ramsey and Edwards (2004) state that "Historically, agricultural education has been an appealing and robust authentic context in which students learned and then applied the scientific laws, concepts, and principles" (p. 87). Agricultural education programs used a curriculum that is student centered and engages students in hands-on learning. The Supervised Agricultural Experience promotes handson application of concepts and theories learned in the classroom and agricultural shop (National FFA Organization, 2014, p. 2). The SAE projects provide opportunities for real-life problem solving. According to Burris and Garton (2007), "the problem based learning $(\mathrm{PBL})$ is a constructivist approach to instruction that revolves around real-world and ill-structured problems" (p. 107).

SAE's provide numerous opportunities for students to apply knowledge and skills learned in the classroom through contextual learning and to make real-world connections through experience-based activities (Ramsey \& Edwards, 2004). The SAE provides real world situations in which the students can apply agriculture, business, and scientific knowledge to solving problems in informal settings. "Researchers have asserted that enriched informal activities outside the classroom correspond to higher scientific reasoning abilities among students" (Ramsey \& Edwards, 2004, p. 89). Informal learning experiences that can improve the students' scientific reasoning ability include a wide variety of activities in the school and community such as the SAE, 4-H, FFA, scouting, 
and partnership activities with businesses, industries, museums, and agricultural and natural resource organizations.

Ramsey and Edwards (2004) note, "Researchers in science education have suggested that students' informal learning experiences play a significant role in their learning of science and in their science achievement" (p. 89). The SAE and involvement in FFA promote the informal learning and application of scientific concepts and theories. Many agricultural education programs have a wide variety of laboratories that teachers can utilize to provide hands-on experiences to students. Shoulders and Meyers (2012) state the following:

Trends in the agriculture industry signal a need for agricultural education to teach scientific problem solving, spurring the United States Department of Agriculture to recommend that students seeking future employment in the agriculture industry have basic science skills and the ability to solve problems with scientific applications. (p. 124)

Agricultural education is an area of studies in which students can learn scientific principles through the agricultural curriculum. "Agriculture laboratories, which can include mechanics laboratories, greenhouses, livestock facilities, land laboratories, and aquaculture laboratories are currently understood [to be] a means for providing students practice in the application of theories taught in the classroom" (Shoulders \& Meyers, 2012, p. 124). Teachers should be utilizing a variety of laboratories that are available to them to engage students in problem solving and scientific learning.

Hands-on learning experiences improve students' interest in the subject and result in better grades and higher retention rates. "People crave experiences requiring 
engagement and promising challenging opportunities to used personal skills" (DeLay \& Swan, 2014, p. 106). Students need to be actively engaged in the application of knowledge learned in the classroom setting through practical application. "The program model for agricultural education provides students with integrated opportunities of coursework, leadership development, and supervised experiences" (DeLay \& Swan, 2014, p. 106). The three components of agricultural education--FFA, the SAE, and classroom/laboratory learning-- tie together all of the theories learned in the classroom to help students develop real world problem solving abilities. The students' interests in class material and motivation provided by the teacher increase the students' chances for a better grade. According to a study conducted by DeLay and Swan (2014), "students struggled with the impersonal, purposeless, teacher-centered focus of the core academic programs but felt they thrived in the personal, purposeful, student-centered focus of the agriculture programs" (p. 115). Agriculture teachers must work to keep students in their classes active and engaged.

One might ask whether teachers are effectively utilizing available laboratories and hands-on activities to enhance the instruction in high school agriculture education classes. Shoulders and Meyers (2012) state, "The presence and usage of agricultural laboratories to some degree is included in the basic philosophy of secondary agricultural education" (p. 125). The used of laboratories and hands-on learning are the basic principles of agricultural education; "however, little research has been conducted on the current used of agricultural laboratories" (Shoulders \& Meyers, 2012, p. 126). “A strong agri-science curriculum was listed as the fifth most effective strategy for retention" (Myers, Dyer, \& Breja, 2014, p. 13). The agricultural education curriculum should have a strong, active 
laboratory program for practical learning to occur. The active used of the laboratories allows the students to demonstrate what they have learned and to achieve success in class and school. "Active strategies like the SAE, project based learning, whole class discussion, and laboratories engage students in actions like exploration and discovery" (DeLay \& Swan, 2014, p. 107).

The agriculture teacher is an important component in experiential learning. “Kolb's Theory of Experiential Learning was a holistic integrative perspective on learning that combines experience, perception, cognition and behavior" (Arnold, Warner, \& Osborne, 2006, p. 32). Kolb's theory has four components for the learning cycle: concrete experience, reflective observations, abstract conceptualization, and active experimentation. The concrete experiences are the "here and now" experiences, which are used to test and validate concepts and provide a main point for learning and testing (Arnold et al., 2006, p. 32). “The reflective observations component encourages students to critically examine a concrete experience" (Arnold et al., 2006, p. 32). The reflection allows students to take ownership of their success or failure and to understand and apply the concrete material. The third stage is abstract conceptualization, which allows the students to generalize about their experiences and strive for improvement. "The fourth stage is active experimentation, which requires the transfer and application of principles to a new situation" (Arnold et al., 2006, p. 32). An agricultural education class should utilize as many opportunities as possible to provide the students the information they need to become actively engaged in learning.

Gilakjani and Ahmadi (2011) believe that "Students learn best by seeing the value and importance of the information presented in the classroom" (p. 469). The SAE 
component of agricultural education provides the experiential learning opportunity for solving problems. Most students are capable of learning through a variety of styles or preferences. The most common styles are visual, auditory, tactile, and kinesthetic. The visual learners easily understand written material, and they will take notes. They will later use these notes to complete assignments or tests. The auditory learners want to hear the information and discuss new ideas to understand material. They will listen intently to lectures and will attend conferences, but noise easily distracts this type of learner. Tactile leaners prefer to touch objects to feel their shape or texture. These students prefer to work with their hands and want to hold the objects. The kinesthetic learners learn best through physical activity. They need to be moving around during lab activities, working in the agricultural mechanics shop or greenhouse, or engaging in other activities that allow them to get up and move around. The movement helps the student to process the information more effectively.

\section{Problem Statement}

In Pedagogy of the Oppressed, Friere (1997) stated that education is "suffering from narration sickness" (pp. 52-53) and that to change the system, the teacher must, in a sense, become a student to help other students pursue inquiry. In Psychological Foundations of Learning, Walls (1999) states that teachers should limit the amount of time they lecture. He emphasizes that "People learn what they DO" (p. 36). "Doing" is an integral part of agricultural education, and "doing to learn" is part of the FFA motto. Why is it, then, that in some agricultural education classes, students are not engaged in activities that help them learn? Listening to lectures, watching films, completing worksheets, and focusing almost exclusively on theory is not "doing." The extent to 
which agricultural teachers engage students in experiential learning seems to vary across the state of West Virginia. The following questions arise:

1. To what extent are West Virginia agricultural education students working actively?

2. To what extent are West Virginia agricultural education students engaged in agricultural laboratory settings?

3. To what extent are West Virginia agricultural education students developing the skills needed to become problem solvers through inquiry and experiential learning practices?

\section{Purpose of the Study}

The purpose of the research study is to determine the method(s) agricultural education teachers used to teach the content skill sets for the Introduction to Agriculture, Food, and Natural Resources course in West Virginia. This study places special emphasis on the extent to which laboratories (and hands-on learning activities) are utilized.

\section{Limitations of the Study}

The study is limited to agricultural education teachers employed in West Virginia during the 2018-2019 school year. The number of teachers who respond to the survey, the degree to which they are willing to share their teaching practices and the honesty of their responses also limit the study. 


\section{CHAPTER II}

\section{Review of Literature}

Agriculture education has always been a strong force behind the growth and development of new ideas and ways to teach and learn the material. "Beginning in the early 1880 's, strong support was increasing nationally for more agricultural instruction in the educational system" (Hillison, 1989, p. 7). The Federal government was getting involved in agricultural education with the passing of several acts that provided support for agricultural education. "A central focus of these efforts was to include agricultural instruction as part of the public school system in order to involve persons in the field at an earlier age" (Hillison, 1989, p. 7). The acts proposed that both elementary and secondary education attempt to incorporate agricultural education. In the late 1800 s, only 19 public high schools had agriculture as part of the curricula. "Between 1901 and 1905, 33 public high schools included agriculture in their curricula, and in five years following, 413 more schools added agriculture to their curricula" (Hillison, 1989, p. 7). By 1915, there were approximately 5,000 public high schools and 250 private schools that offered agriculture as part of their school day offerings (Hillison, 1989, p. 10). "Instruction at that time was for both sexes, 95,148 students of whom 40,892 were girls" (Hillison, 1989, p. 7). "In 1908, the Country Life Commission was appointed by President Roosevelt" (Agricultural Education- Early Congressional Efforts, An Early Philosophy of Agricultural Education, 2016, p. 6). The main goal of the commission was to make educational improvements.

The original colleges in America taught the classics and modeled curricula on that found in English Universities. The colleges designed curricula to educate the students in 
the areas of religion, medicine, and law. Very few schools offered an agriculture program. "The development of agricultural societies was the first systematic attempt to improve agriculture" (Place, 2015, p. 5). These societies, established after the Revolutionary War, grew to about 900 at the national level. "The first organized society and one of the most notable was the Philadelphia Society for Promoting Agriculture, established in 1785 by Benjamin Franklin" (Place, 2015, p. 5). The societies published journals, had education programs, and offered rewards for agricultural innovations. The societies provided a wealth of new information about crop and livestock production for farmers, who were slow to accept the information. To promote changes needed to improve America's agricultural production, the societies pushed for colleges and programs to educate students about agriculture.

Jonathan Turner and Thomas Clemson were two of the early supporters of agriculture education. Turner was a Yale graduate who became a farmer, newspaper editor, and professor at Illinois College. He developed a "Plan for a State University for the Industrial Classes in 1850 that contained many of the ideas that became the Morrill Act of 1862" (Place, 2015, p. 5). Clemson advocated for science and agriculture education and helped to establish colleges along the eastern coast of the United States.

"The first school that was devoted to the study of agriculture was Gardiner Lyceum in Maine, established in 1823" (Place, 2015, p. 5). After the establishment of the school in Maine, other schools such as Kings College (Columbia University) and Harvard College soon started programs in agriculture. Pennsylvania, Michigan, and Maryland became the first states to establish schools, which taught agriculture and the mechanical arts (Place, 2015, p. 5). 
"Pennsylvania established the first agricultural high school in 1855, which in 1862 became the state's Land-Grant College and eventually Pennsylvania State University" (Place, 2015, p. 5). Evan Pugh, the first president, envisioned a school that would not only train farmers but also research specialists and rural schoolteachers, who would be professionally scientific in the combination of agriculture and mechanic arts. The Michigan Agricultural Society pressured Michigan into opening the first college of agriculture in 1855, while Maryland opened a college of agriculture in 1856 (Place, 2015, p. 5).

Colleges developed agricultural education prior to the Smith- Hughes Act under the Morrill Land Act of 1862, signed by President Abraham Lincoln. The act provided the donation of public lands to several states to sell. The finances raised from the sales provided for the endowment, support, and maintenance of one college, which should teach scientific, classical studies, military tactics, agriculture, and mechanic arts. (The $125^{\text {th }}$ Second Morrill Act Anniversary Celebration at North Carolina A\&T State University, 2016).

In 1887, the Hatch Act provided for federal funding for agricultural experiment stations. Agricultural experiment stations conduct research that includes the difficulty and improvements to food production and agricultural business. The stations work with farmers, suppliers, processors, and teachers. The stations study how agriculture affects the environment, society, and the economics of an area. The scientists research a variety of issues such as crop varieties, different types of soil, livestock and animal technology. For example, at the West Virginia University Research Station, "the first scientific study of West Virginia insects was started, research into the oak wilt disease and a blight 
resistant tomato was developed" (150 ${ }^{\text {th }}$ Anniversary Celebrating Research, 2017, p. 1). "The act asserts that in any state with two land grant colleges, the funds must be split equally, unless the legislature says otherwise" (The $125^{\text {th }}$ Anniversary Celebration at North Carolina A\&T State University, 2016, p. 1).

Many farmers expressed interest in vocational education through the National Grange, which strongly supported The Paige-Wilson Vocational Bill, one of the early vocational bills, provided funding for agricultural education. The National Grange has been supporting education since the early 1870s (Hillison, 1989). "The National Grange encouraged every state Grange to assist with the enactment of the Paige-Wilson Vocational Bill and to make [the Grange's] influence rigorous and continuous" (Hillison, 1989, p.9).

The Association of American Agricultural Colleges and Experiment Stations expressed two concerns about the federal funding of vocational education: "One concern was with the location of experiment stations, which the organizations feared would be attached to the Congressional District Agriculture Schools. The second concern had to do with the merging of co-operative extension service and vocational education" (Hillison, 1989, p.9). The writers of the bill assured the Association of American Agricultural Colleges and Experiment Stations that the experiment stations would be separate from schools, nor would the extension service be part of vocational education in the SmithLevers Act of 1914, which was a forerunner of the Smith-Hughes Bill (Hillison, 1995).

"The Congressional district agricultural schools- because of how they were established, their facilities, and their curricula — are, when taken together as a group, an important early example of vocational agriculture" (Hillison, 1989, p.12). Public and 
political influences of the time did have an impact on the agricultural education, but the Congressional district schools helped to bring agricultural education into the public schools through adaptation of the curricula, administrational procedures, and the types of students in the schools. The increase in the growth in agricultural education was inspired through high school curriculum in three states: Alabama, Georgia, and Virginia (Hillison, 1989).

"The Alabama legislature passed the first Congressional district school legislation on February 28, 1889" (Hillison, 1989, p. 8). The act established two branch experiment stations and agriculture schools. The Alabama State Grange and farmers were instrumental in passage of the act. "The Alabama legislation called the schools agricultural schools and appropriated six thousand dollars to be split evenly between two locations in north Alabama and southeast Alabama" (Hillison, 1989, p. 8). The act also authorized more funds and the purchase of lands for the schools.

"Georgia was the second state to establish Congressional district high schools, which were conceived and patterned after the Alabama schools. In 1905, Governor Joseph Terrell endorsed the concept of agricultural education in his address to the General Assembly" (Hillison, 1989, p. 8). The Georgia legislature passed the law on August 18, 1906, establishing and maintaining the schools of agriculture and mechanic arts. The agriculture schools were to be branches of University of Georgia (Hillison, 1989).

Virginia was the third state to establish Congressional district schools. S.W. Fletcher, Director of the Virginia Agriculture Experiment Station, encouraged the addition of agricultural education in public schools. In 1908, Virginia passed a bill to 
permit the inclusion of agricultural education in public schools. In 1910, the legislature expanded the act to mandate at least one school in each congressional district, be selected by the state board of education to offer a course in agriculture, domestic arts, sciences, and manual training. The act also authorized the purchase, lease or acceptance through donations of five acres of land to provide practical experience and demonstration of agricultural science (Hillison, 1989).

The facilities of the Congressional district schools differed from each other, based on legislative specification, local contributions and conditions. A basic school had a main building, two dormitories, several laboratories, and a school farm. One school in Elk Creek, Virginia had a three story brick building, eleven large classrooms, office, library, two music rooms, auditorium, and three laboratories. Its purpose was "To emphasize the importance of experiential learning, most schools contained several laboratories" (Hillison, 1989, p. 9).

"The Thirty-ninth Annual Report of 1911 noted that the name agricultural school was misleading because the schools taught broad-based coursework, crossing several disciplines and competencies" (Hillison, 1989, p. 10). The schools in Georgia recommended a curriculum of four years with courses in English, mathematics, history, science, agriculture, farm mechanics, and domestic arts and science (Hillison, 1989). In Alabama, the southern schools included botany, and practical work as part of the curriculum. The school farm was a major part of the curriculum, and the students were encouraged to do experiments and investigations on plots on the farm. They also learned about farm mechanics, mechanical drawing and elementary surveying. The life 
experiences helped to make the classroom theory more applicable to the real world for the students (Hillison, 1989).

The Congressional District Schools existed in only three states for a limited amount of time, but they proved that agricultural education could be taught in the high schools as part of the curriculum. The Congressional District Schools set a precedent for the passage of the Smith-Hughes Act of 1917. The schools demonstrated a curriculum that included classical educational curriculum along with agricultural curriculum. The schools, also, helped in the design of the facilities, administration, instructors, and curriculum (Hillison, 1989).

The Hatch Act of 1887 provided an opportunity for young people who grew up in rural areas to attend the land grant colleges. This did not happen as planned, so educators designed other programs. The first was the establishment of the experimental stations by the act. The second was the creation of the extension service by the Smith Levers Act of 1914. Third, the Smith-Hughes Act of 1917 created and funded vocational programs at the secondary level (Agricultural Education- Early Congressional Efforts, An Early Philosophy of Agricultural Education, 2016).

The Nelson Amendment to Agricultural Appropriations Bill in March of 1907 authorized the expenditure of federal funds to colleges of agriculture for courses in the preparation of teachers in agriculture and mechanic arts. "By 1908, $\$ 25,000$ was appropriated annually to each state for such purposes" (Hillison, 1989, p. 2). This amendment came as Georgia, Alabama, and Virginia developed the Congressional district schools. The amendment gave a large boost to agricultural education for teachers. 
During this time, the Department of Agriculture was also promoting training for agriculture teachers and providing materials for the classes (Hillison, 1989).

Many organizations throughout the country supported The Smith-Hughes Act of 1917. The National Society for the Promotion of Industrial Education (NSPIE) was founded to bring together the organizations interested in supporting the passage of federal legislation supporting the vocational education bill. The members were men of affairs, employers, representatives of labor, social students, and educators. The American Federation of Labor (AFL) supported a vocational program that was in the public education system and not private. The AFL wanted a system of education that would provide skilled training for their children. The National Association of Manufactures (NAM) was concerned with the quality and ability level of new employees graduating from school. NAM and its members viewed vocational education as a way of educating and training new employees to accomplish the skilled jobs (Hillison, 1989).

The United States Chamber of Commerce was interested in having a prepared workforce that would improve the efficiency of the industrial areas. In 1913, the organization passed a resolution supporting vocational education, which emphasized the following vocational areas: manufacturing, commerce, agriculture, and home economics. In a survey of its members in 1916, the chamber determined that two-thirds of members, who returned the surveys, supported vocational education. The National Democratic Party supported the vocational act for agriculture. Party members at the 1912 and 1916 conventions passed a declaration for national grants for agricultural education, household arts, and industrial training. Wallace's Farmer, a prominent rural magazine, was part of an influential form of media. The magazine was quoted as saying if the director could get 
the teacher to lay down the book and present problems that might occur in real farming, then a better farmer would be produced (Hillison, 1995). W. D. Hoard, a former governor of Wisconsin and trustee of University of Wisconsin, in 1895, stated that in agriculture, many farmers had not had any special training in the field, but they were guided by providence (Hillison, 1995). No other business would permit this to happen, so there should be a specialized field of study for them. Most of the farmers did not understand the ideas of proteins, carbohydrates, or free nitrogen in the soil. A number of prominent education advocates believed that farmers should be like craftsmen in other industries, thoroughly trained in the aspects of their jobs and the needs of the livestock and crop plants (Hillison, 1995).

"The National Grange claimed a degree of credit for the passage of the SmithHughes Act when it stated that the Grange fathered legislation creating the Vo-Ag programs and consistently supported advancement of the work since it was established" (Hillison, 1995, p. 9). The Grange had been a supporter of education for rural America since its conception and still fights for agricultural education.

The Smith-Hughes Act of 1914 required that agricultural education include the directed or supervised practice of agriculture. The Act specified that students had to participate in a work experience outside of the classroom. The experience had to focus on livestock and crop projects. The Act provided federal money for the funding of the agricultural programs along with matching state and local financing. The funding was to provide for the training and salaries of teachers, supervisors, and directors of agriculture, and for programs focusing on home economics, agricultural economics, and industrial subjects. The states had to submit plans that detailed the used of the money for the 
programs. The Smith-Hughes Act encouraged the students and schools to learn through hands-on applications and experiential learning, using world problems (Agricultural Education-Early Congressional Efforts, An Early Philosophy of Agricultural Education, 2016).

The report, "Transforming Agricultural Education for a Changing World" (2014), published by The National Academies, states that “today's global agricultural enterprise stretches beyond the farm to encompass hundreds of entities involved in the production and distribution of food and other agricultural products worldwide" (p. 4). "A link has been established between experiential learning and improvement in science skills: Historically, agricultural education has been an appealing and robust authentic context in which students learned and applied the scientific laws, concepts, and principles" (Ramsey \& Edwards, 2004, p. 87). The agricultural education programs used a curriculum that is student centered and engages students in hands-on learning. The Supervised Agricultural Experience (SAE) promotes hands-on application of concepts and theories learned in the classroom and agricultural shop (National FFA, 2004). According to "Experiential Learning: Supervised Agricultural Experience Program," the SAE involves more than the student and the teacher:

The supervised agricultural experience is defined as programs that consist of all practical agriculture activities of educational value, conducted by students outside the classroom, and laboratory instructional time, or on school-released time for which systematic instruction and supervision are provided by teacher, parents, employers, and others (Missouri Program Planning Handbook, 2003, p.5). 
The SAE program should help students select and prepare for successful careers, and to make informed life-long choices about their food, fiber, and natural resource usage. The SAE programs are individual projects that involve the supervision from their instructor and parents or others, depending the project. The major areas of study in the SAE program are entrepreneurship, exploratory, placement, research/experimental, and analytical. The SAE allows the students the ability to apply knowledge learned in class to practical applications through the various phases of their project. The students have the opportunity to apply their knowledge of scientific, agricultural, and business to solving problems and issues occurring in their SAE. Research has shown that informal activities outside the classroom help the students to develop stronger scientific reasoning abilities. This informal education can be through an agricultural education programs SAE, 4-H, scouting, or other types of partnerships within the community (Arnold et al., 2006, pp. 31-32).

The problem based learning (PBL) is a constructivist approach to instruction that revolves around real-world issues (Burris \& Garton, 2007). The used of this method continues to allow the students the opportunities for practical application of concepts learned in the classroom setting. PBL promotes the both acquisition of content knowledge and the development of thinking skills and strategies" (Burris \& Garton, 2007, p. 107). The agricultural education programs should be promoting the used of PBL through student completion of SAEs. In West Virginia, students are required to complete two years of SAE credit before graduation to be vocational completers.

Many of the agricultural education programs have a wide variety of laboratory and hands-on learning facilities for the student's use. Laboratories are an important 
component of the agricultural education program for providing the experiential opportunity for the students (Saucier \& McKim, 2011). The trends in today's agriculture industry from production to research indicate a need for more laboratory used in the programs. The United States Department of Agriculture has recommended that students seeking employment in the industry have the basic scientific skills and the ability to solve problems with those skills. Agricultural education laboratories can include mechanics shop, greenhouses, livestock facilities, land laboratories, and aquaculture for the students to used as method of practical application of knowledge learned in the classroom. The laboratory (shop) Content Standards Objectives of the West Virginia Department of Education are a major part of the agriculture programs in secondary schools. The teachers who are using these laboratories have a more positive prospective of student learning. The used of the laboratories and agricultural education learning areas produce students who have less apathy toward learning (www.wvde.gov, 2017).

Laboratories employ a wide variety of learning techniques and strategies from the visual to hands-on learning. According to Gilakjani (2011), "students learn best by seeing the value and importance of the information presented in the classroom." (p. 469). The agricultural education instructors have an opportunity to engage students in a wide variety of activities from the shop and class laboratory to the SAE and community service projects. The activities caused the student to develop the thinking skills needed to apply theoretical knowledge to real world situations.

Kolb's experiential learning theory "develops a holistic model of the experiential learning process and multilinear model for adult development." (Kolb \& Kolb, 2005, p.194). Experiential learning is the application of classroom knowledge to real problems. 
The SAE, laboratory, and shop activities are the most useful for the application of the knowledge.

The SAE allows the student the opportunity to apply their knowledge to a specific project of interest, which can range from raising livestock for breeding, showing, or marketing to placement and research. The activities allow the students to pursue areas of interest based on their knowledge gained from classroom instruction. According to Kolb and Kolb (2005), "learning styles describe the individual difference in learning based on the learner's preference to employing different phases of the learning cycle" (pp. 194195).

The learning cycle has two levels:

The first level is concrete experience and abstract conceptualization and active experimentation and reflective observation. The second level is broken down into four types of learning, which are as follow:

1. Diverger: Type 1

2. Assimilator: Type 2

3. Converger: Type 3

4. Accommodator: Type 4. (Felder \& Brent, 2005, pp. 59-60).

Students who want the concrete experience or abstract conceptualization differ in how they acquire new information. The active experimentation or reflective observations differ in how the information is processed. At the second level, the divergers are concrete and reflective learners. They want to know how the information will affect their experience, interests, and future. They want to be able to apply the information to real issues. 
The assimilator is abstract and reflective. This type of student wants the information in a well-organized and logical manner but needs time to reflect on how this information will affect them.

The convergers are abstract and active learners who want the opportunity to participate in well-defined tasks and learn from their mistakes. They want the opportunity to prove an idea or theory and learn from their mistakes.

The accommodators are concrete and active in their learning style. This type of learner wants to apply their knowledge to new situations to solve real issues and problems. They want to discover things for themselves and work on problem solving (Felder \& Brent, 2005).

How teachers present information and how students receive information determine the extent to which experiential learning benefits students. According to Miller (2001), "there are three styles of learning; these are visual, auditory, and kinesthetic" (p. 1). The visual and verbal learner processes the information better when teachers present it visually and in a written format. This type of learner would rather read and reflect at his/her leisure. The visual non-verbal learner assimilates the information best when teachers present information in the form of a picture or design format. The learner benefits from posters, charts, and videos. The more visual a presentation is, the easier it will be for the students to process the information.

The auditory learner learns best when the material is presented verbally. These students learn best in the classroom through lecture and group discussion, i.e. listening and speaking formats work best (Miller, 2001). 
The kinesthetic learner is hands-on and enjoys being physically active in the class. These students benefit most and acquire information better through labs, shop projects, and SAEs. They learn better by being physically active and manipulating the materials. These students need to experience the material and stay actively engaged (Miller, 2001).

\section{Summary}

Agricultural education has a long history in our country. The programs started before the civil war with agricultural societies providing instruction and research to farmers.

For over a century, the federal government has provided funding for agricultural programs. Passage of federal laws has helped to create schools for agricultural education, hands-on learning and the practical application of theory learned in the classroom. One might conclude that a combination of lectures, labs, shop, FFA and SAE's in agricultural education programs can provide learning experiences for all students.

Many organizations have provided support for the agricultural education programs, and many still do. The organizations help to lobby for laws that provide the materials needed for the hands-on learning and an educated agricultural labor force. As time has changed, so have students, who do not all learn in the same manner. The instructor must determine the best learning style or employ a variety of learning styles for the students to encourage them to be active participants in learning. Students that are in the agricultural programs work with problem-based learning, think critically and apply their knowledge to real world problems.

Because agricultural education employs multiple methods of teaching and learning, students are better able to solve problems. Experiential learning in agricultural 
education programs contributes significantly to the success of those programs and the success of students who complete those programs. 


\section{CHAPTER III}

\section{Methodology}

\section{Research Design}

The researcher used an electronic descriptive survey to collect data from high school agricultural education instructors in West Virginia. According to Ary, Jacobs, Sorenson and Walker (2014), "Surveys permit the researcher to summarize the characteristics of different groups to measure their attitudes and opinions toward some issue" (p. 399). Each teacher survey will have the opportunity to explain hands-on methods used and his or her philosophy of agricultural education.

\section{Population of the Study}

The population of the study was 104 agricultural education instructors employed in West Virginia during the 2018-2019 school year. The population was determined using the official directory maintained by the Agricultural and Extension Education Department at West Virginia University. The researcher used a census because of the small target population: therefore, the target and accessible populations were the same.

\section{Instrumentation}

The researcher developed a survey using the content skills sets approved for the Introduction to Agriculture, Food, and Natural Resources course. The survey consisted of two sections:

- Section 1 asked the respondents to indicate the way(s) each content skill sets approved for the course was taught.

- Section 2 included demographic information about the participants, including highest degree earned and years of experience. 


\section{Validity and Reliability}

A panel of experts in the Davis College of Agriculture, Natural Resources, and Design at West Virginia University reviewed the instrument to establish content and face validity. The reliability of the instrument was found to be extensive (Robinson, Shaver, \& Wrightsman, 1991).

\section{Data Collection}

Dillman's Total Design Survey Method procedures were used to guide the data collection procedures. An introduction email (see Appendix A) was sent to all participants introducing the survey and asking for their participation. On October 16, 2018 all participants were emailed a cover letter (see Appendix B) explaining the research and a link to the Qualtrics survey (see Appendix D). A deadline for completing the survey was established. A follow-up letter (see Appendix C) was sent with the link to non-respondents 10 days later and a second letter was sent seven days later. The last responses were recorded on December 6, 2018 prior to the survey being closed. A personal phone call to the non-responders and a phone interview was conducted.

\section{Non-Response Error}

Ary et al. (2014) state that if the "response rate remains below 75\%, try to learn something about the characteristics of the non-respondents" (p. 434). The group of respondents were divided into two groups based on the time of their response. Individuals who responded to the survey on or before the original deadline were considered as "early respondents.” Because late respondents are most like non-respondents (Miller \& Smith, 1983) the analysis provided an estimate of non-response error. 


\section{Data Analysis}

Quantitative data was analyzed utilizing the SPSS 23.0 for Windows. The level of significance was set a priori at $\alpha \leq 0.05$ for all statistical tests. Descriptive analyses appropriate for the respective scales of measurement were performed on the data including measures of central tendency (mean, median, or mode) and variability (frequencies or standard deviation). The results were represented as frequencies and percentages as well as mean, median, and mode in both table and narrative form.

\section{Used of Findings}

The findings/results will be published. The results may help agricultural education teachers retain current students and increase enrollment of future students. Once West Virginia agricultural education teachers receive results of the study and see the number and types of laboratories, supervised practices, library and computer activities, field trips, and classroom activities that are incorporated in introductory agricultural education courses across the state, they may reinforce activities they are already using to engage students; or teachers may decide to incorporate more practices used by their colleagues. 


\section{CHAPTER IV}

\section{Findings}

The accessible population consisted of 104 secondary agricultural educators in West Virginia. Thirty-one educators returned surveys (29.8\%). Of the surveys returned, fifteen could not be used for data collection because these respondents do not teach introduction to agriculture, food, and natural resources. The final set of useable surveys number sixteen.

\section{Demographic Characteristics of Respondents}

\section{Gender}

Respondents identified their gender. The mode for gender was male. Nine of the respondents $(56.25 \%)$ were male, while seven $(43.75 \%)$ were female (see Table 1$)$. Sixteen of the respondents teach Introduction to Agriculture, Food, and Natural Resources, while 15 do not teach the class.

Table 1

Gender of Respondents and Teaching of Introduction to Agriculture, Food, and Natural Resources

\begin{tabular}{lcccc}
\hline & \multicolumn{2}{c}{ Yes } & \multicolumn{2}{c}{ No } \\
\hline Male & $f$ & $\%$ & $f$ & $\%$ \\
Female & 9 & 56.25 & 12 & 80.00 \\
\hline
\end{tabular}

\section{Age of Respondents}

Respondents indicated their age, using 10-year categories. The median age for respondents that teach introduction to agriculture, food, and natural resources fell within 
the 20-29 years of age category. Six respondents (37.50\%) identified their age in the 2029 year category. Four respondents $(25.00 \%)$ listed $30-39$ years as their age category, and another three respondents (18.75\%) indicated their age was in the $40-49$ year category. The 50-59 year category included two (12.50\%), and one (6.25\%) indicated their age category was 60-69 years (see Table 2).

Table 2

Age of Respondents Compared to Teaching the Introduction to Agriculture, Food and Natural Resources (WVEIS 0101) Course

\begin{tabular}{lcccc}
\hline & \multicolumn{2}{c}{ Yes } & \multicolumn{2}{c}{ No } \\
\cline { 2 - 5 } & $\mathrm{f}$ & $\%$ & $\mathrm{f}$ & $\%$ \\
\hline $20-29$ years & 6 & 37.50 & 1 & 6.67 \\
$30-39$ years & 4 & 25.00 & 5 & 33.33 \\
$40-49$ years & 3 & 18.75 & 6 & 40.00 \\
$50-59$ years & 2 & 12.50 & 3 & 20.00 \\
$60-69$ years & 1 & 6.25 & 0 & .00 \\
70 years or older & 0 & .00 & 0 & .00 \\
\hline
\end{tabular}

\section{Years of Teaching Experience}

Using five-year categories, the participants indicated their years of teaching experience. The median level of experience was 5-10 years. Six participants (37.50\%) indicated teaching experience of 5-10 years. The 0-4 year category, $11-15$ year category, $21-25$ year category and the Over 30 year category each had two participants $(12.50 \%)$, while the 16-20 year category and 26-30 year each had one participant (6.25\%) who teaches Introduction to Agriculture, Food, and Natural Resources (see Table 3). 
Table 3

Years of Teaching Experience Compared to Teaching the Introduction to Agriculture, Food and Natural Resources (WVEIS 0101) Course

\begin{tabular}{lcccc}
\hline & \multicolumn{2}{c}{$\begin{array}{c}\text { Do you teach the Introduction to Agriculture, Food and Natural } \\
\text { Resources (WVEIS 0101) course? }\end{array}$} \\
\cline { 2 - 5 } & $\mathrm{f}$ & $\%$ & $\mathrm{f}$ & No \\
\hline $0-4$ years & 2 & 12.50 & 0 & .00 \\
$5-10$ years & 6 & 37.50 & 5 & 33.33 \\
$11-15$ years & 2 & 12.50 & 1 & 6.67 \\
$16-20$ years & 1 & 6.25 & 4 & 26.67 \\
$21-25$ years & 2 & 12.50 & 1 & 6.67 \\
$26-30$ years & 1 & 6.25 & 2 & 13.33 \\
Over 30 years & 2 & 12.50 & 2 & 13.33 \\
\hline
\end{tabular}

\section{Level of Education of Respondents}

The participants indicated their level of education. The median level of education for participants who teach Introduction to Agriculture was Master of Science/Arts. Nine participants (56.25\%) indicated that their education level was Master of Science/Arts, while seven (43.75\%) indicated that their level of education was Bachelor of Science/Arts. None of the participants indicted that their level of education was Doctor of Education or Doctor of Philosophy (see Table 4). 
Table 4

Level of Education of Respondents

\begin{tabular}{lcccc}
\hline & \multicolumn{2}{c}{ Yes } & \multicolumn{3}{c}{ No } \\
\cline { 2 - 5 } & $\mathrm{f}$ & $\%$ & $\mathrm{f}$ & $\%$ \\
\hline $\begin{array}{l}\text { Bachelor of Science/Arts } \\
\text { (BS/BA) }\end{array}$ & 7 & 43.75 & 5 & 33.33 \\
$\begin{array}{l}\text { Master of Science/Arts } \\
\text { (MS/MA) e }\end{array}$ & 9 & 56.25 & 10 & 66.67 \\
$\begin{array}{l}\text { Doctor of Education } \\
\text { (EdD) }\end{array}$ & 0 & .00 & 0 & .00 \\
$\begin{array}{l}\text { Doctor of Philosophy } \\
\text { (PhD) }\end{array}$ & 0 & .00 & 0 & .00 \\
\hline
\end{tabular}

\section{Methods Used to Teach Introduction to Agriculture, Food and Natural Resources. Basic Finance - Personal Inventory, Net Worth, Income, and Expense}

Fifty percent of the respondents $(\mathrm{f}=13)$ used discussion to teach Basic Finance Personal Inventory, Net Worth, Income, and Expense. Twelve of the respondents (46.15\%) used project-based methods to teach Basic Finance - Personal Inventory, Net Worth, Income, and Expense. Eleven respondents (42.31\%) used the library and 11 respondents $(42.31 \%)$ used a computer lab to teach the concept of basic finance. Nine of the respondents $(34.62 \%)$ used lecture to teach Basic Finance - Personal Inventory, Net Worth, Income, and Expense. Seven of the respondents (26.92\%) used inquiry while another seven respondents $(26.92 \%)$ used the greenhouse to teach the concept. Six of the respondents (23.08\%) used classroom demonstration and six other teachers $(23.08 \%)$ used textbooks and handouts. Three of the respondents (11.54\%) used other methods in the laboratory to teach the concept, while two of respondents $(7.69 \%)$ used a meats 
laboratory to teach the concept. One respondent (3.85\%) used forestry, one used land laboratory, and one used mechanics laboratory to teach the concept. None of the respondents indicated the use of biotechnology laboratory or field trip to teach the concept, and none indicated that they do not teach the concept (see Table 5).

Table 5

Methods Used to Teach Agribusiness CSS: Basic Finance - Personal Inventory, Net Worth, Income, Expenses

\begin{tabular}{|c|c|c|c|}
\hline Location & Delivery & $\mathrm{f}$ & $\%$ \\
\hline Classroom & Discussion & 13 & 50.00 \\
\hline Classroom & Project Based & 12 & 46.15 \\
\hline Other & Library/ computer lab & 11 & 42.31 \\
\hline Classroom & Lecture & 9 & 34.62 \\
\hline Classroom & Inquiry & 7 & 26.92 \\
\hline Laboratory & Greenhouse & 7 & 26.92 \\
\hline Classroom & Demonstration & 6 & 23.08 \\
\hline Classroom & Textbooks/ Handouts & 6 & 23.08 \\
\hline Laboratory & Other & 3 & 11.54 \\
\hline Laboratory & Meats laboratory & 2 & 7.69 \\
\hline Laboratory & Forestry & 1 & 3.85 \\
\hline Laboratory & Land laboratory & 1 & 3.85 \\
\hline Laboratory & Mechanics laboratory & 1 & 3.85 \\
\hline Laboratory & Biotechnology laboratory & 0 & 0.00 \\
\hline Other & Do not Teach & 0 & 0.00 \\
\hline Other & Field Trip & 0 & 0.00 \\
\hline
\end{tabular}




\section{Create a Plan for Their Own Agricultural Enterprise.}

Twenty-two respondents (84.62\%) used project-based learning to teach Create a Plan for Their Own Agricultural Enterprise. Eleven individuals (42.31\%) used classroom discussion and eleven respondents (42.31\%) used library and computer labs to teach the concept of creating a plan. Eight (30.77\%) respondents used inquiry to teach the concept, while six (23.08\%) used classroom lecture. Five of the respondents (19.23\%) used the laboratory greenhouse to teach the concept. Four of the respondents (15.38\%) used textbooks and handouts to teach the concept. Three of the respondents (11.54\%) used a meats laboratory, and another three (11.54\%) used mechanics laboratories to teach the concept. Two of the respondents (7.69\%) used demonstration, other, or field trips, while one respondent (3.85\%) used biotechnology laboratory to teach creating a plan. None of the respondents used either forestry or land laboratory to teach the concept of creating a plan for agricultural enterprises (see Table 6).

Table 6

Methods Used to Teach Agribusiness CSS: Create a Plan for Their Own Agricultural Enterprises

\begin{tabular}{llcc}
\hline Location & Delivery & $\mathrm{f}$ & $\%$ \\
\hline Classroom & Project Based & 22 & 84.62 \\
Classroom & Discussion & 11 & 42.31 \\
Other & Library/computer lab & 11 & 42.31 \\
Classroom & Inquiry & 8 & 30.77 \\
Classroom & Lecture & 6 & 23.08 \\
Laboratory & Greenhouse & 5 & 19.23 \\
\hline
\end{tabular}


Table 6 (continued)

Methods Used to Teach Agribusiness CSS: Create a Plan for Their Own Agricultural Enterprises

\begin{tabular}{lllc}
\hline Location & Delivery & $\mathrm{f}$ & $\%$ \\
\hline Classroom & Textbooks/Handouts & 4 & 15.38 \\
Laboratory & Meats laboratory & 3 & 11.54 \\
Laboratory & Mechanics laboratory & 3 & 11.54 \\
Classroom & Demonstration & 2 & 7.69 \\
Laboratory & Other & 2 & 7.69 \\
Other & Field Trip & 2 & 7.69 \\
Laboratory & Biotechnology laboratory & 1 & 3.85 \\
Laboratory & Forestry & 0 & 0.00 \\
\hline
\end{tabular}

\section{Create an Advertisement for an Agricultural Product.}

Nineteen respondents (73.08\%) used project- based learning to teach Create an Advertisement for an Agricultural Product. Nine individuals (34.62\%) used the library or computer lab to teach the concept. Eight respondents $(30.77 \%)$ used one of the following methods to teach the concept either discussion or greenhouse. Inquiry is the method of teaching the concept for five of the respondents (19.23\%). Four respondents $(15.38 \%)$ used demonstration, four (15.38\%) used textbooks or handouts, and another four $(15.38 \%)$ used the meats laboratory. Three respondents used classroom lecture $(11.54 \%)$, and three respondents used the mechanics laboratory $(11.54 \%)$ to teach the concept. Two respondents $(7.69 \%)$ used other laboratory methods to teach the concept, while one respondent (3.85\%) used forestry, and another one (3.85\%) used land laboratory. None 
of the respondents used biotechnology laboratory or do not teach the concept (see Table 7).

Table 7

Methods Used to Teach Agribusiness CSS: Create an Advertisement for an Agricultural Product.

\begin{tabular}{|c|c|c|c|}
\hline Location & Delivery & $\mathrm{f}$ & $\%$ \\
\hline Classroom & Project Based & 19 & 73.08 \\
\hline Other & Library/computer lab & 9 & 34.62 \\
\hline Classroom & Discussion & 8 & 30.77 \\
\hline Laboratory & Greenhouse & 8 & 30.77 \\
\hline Classroom & Inquiry & 5 & 19.23 \\
\hline Classroom & Demonstration & 4 & 15.38 \\
\hline Classroom & Textbooks/handouts & 4 & 15.38 \\
\hline Laboratory & Meats laboratory & 4 & 15.38 \\
\hline Classroom & Lecture & 3 & 11.54 \\
\hline Laboratory & Mechanics laboratory & 3 & 11.54 \\
\hline Laboratory & Other & 2 & 7.69 \\
\hline Laboratory & Forestry & 1 & 3.85 \\
\hline Laboratory & Land laboratory & 1 & 3.85 \\
\hline Laboratory & Biotechnology laboratory & 0 & 0.00 \\
\hline Other & Do not Teach & 0 & 0.00 \\
\hline
\end{tabular}


Methods of Marketing Agricultural Commodities, Products, and Services in the Domestic and International Markets.

Fifteen of the respondents (57.69\%) used project-based learning to teach the concept of Methods of Marketing Agricultural Commodities, Products, and Services in the Domestic and International Markets. Eleven of the respondents used discussion (42.31\%), and eleven of the respondents (42.31\%) used lecture to teach the concept. Seven of the respondents (26.92\%) used the library or computer lab to cover the concept, while six of the respondents (23.08\%) used inquiry, and another six respondents (23.08\%) used the greenhouse to teach the concept. Three of the respondents $(11.54 \%)$ used classroom demonstration, three (11.54\%) used textbooks and handouts, and three (11.54\%) used meats laboratory to teach marketing in domestic and international markets. Two of the respondents $(7.69 \%)$ do not teach the concept. One respondent (3.85\%) used mechanics laboratory, one respondent (3.85\%) used other, and one respondent (3.85\%) used field trips to teach the concept. None of the respondents used biotechnology laboratory, forestry or land laboratory to teach the concept (see Table 8). 
Table 8

Methods Used to Teach Agribusiness CSS: Methods of Marketing Agricultural Commodities, Products, Services in Domestic and International Markets

\begin{tabular}{|c|c|c|c|}
\hline Location & Delivery & $\mathrm{f}$ & $\%$ \\
\hline Classroom & Project Based & 15 & 57.69 \\
\hline Classroom & Discussion & 11 & 42.31 \\
\hline Classroom & Lecture & 11 & 42.31 \\
\hline Other & Library/computer lab & 7 & 26.92 \\
\hline Classroom & Inquiry & 6 & 23.08 \\
\hline Laboratory & Greenhouse & 6 & 23.08 \\
\hline Classroom & Demonstration & 3 & 11.54 \\
\hline Classroom & Textbooks/handouts & 3 & 11.54 \\
\hline Laboratory & Meats laboratory & 3 & 11.54 \\
\hline Other & Do not Teach & 2 & 7.69 \\
\hline Laboratory & Mechanics laboratory & 1 & 3.85 \\
\hline Laboratory & Other & 1 & 3.85 \\
\hline Laboratory & Field Trip & 1 & 3.85 \\
\hline Laboratory & Biotechnology laboratory & 0 & 0.00 \\
\hline Laboratory & Forestry & 0 & 0.00 \\
\hline Laboratory & Land laboratory & 0 & 0.00 \\
\hline
\end{tabular}

\section{Researching Local Supply and Demand of Agricultural Products.}

Twelve respondents (46.15\%) cover the concept of Researching Local Supply and Demand of Agricultural Products using project-based methods. Nine of the respondents (34.62\%) used classroom discussion of the CSS for research local supply and demand of 
agricultural products. Seven of the respondents (26.92\%) used inquiry, and seven respondents $(26.92 \%)$ used the library or computer lab. Six respondents $(23.08 \%)$ used the greenhouse to teach the concept. Five respondents (19.23\%) used classroom lecture. Three respondents $(11.54 \%)$ used textbooks and handouts, three (11.54\%) used meats laboratory, and three (11.54\%) do not teach the concept. Two of the respondents $(7.69 \%)$ used classroom demonstration. One respondent (3.85\%) used mechanics laboratory, one (3.85\%) used other methods, and one (3.85\%) used field trips to teach the concept. None of the respondents used biotechnology laboratory, forestry or land laboratory to teach the concept (see Table 9).

\section{Return on Investment.}

Ten of the respondents (38.46\%) used classroom discussion and another ten (38.46\%) used classroom lecture to cover the Return on Investment component of agribusiness. Nine of the respondents $(34.62 \%)$ used the project-based method for return on investment. Six of the respondents $(23.08 \%)$ used textbooks, six more respondents $(23.08 \%)$ used the laboratory greenhouse, and six others $(23.08 \%)$ used the library or computer lab as their preferred method. Five (19.23\%) used classroom inquiry, and five (19.23\%) used classroom demonstration for their method. Three of the respondents $(11.54 \%)$ used the meats laboratory. Two respondents $(7.69 \%)$ used the mechanics laboratory, and two $(7.69 \%)$ used field trips to cover return on investment. One $(3.85 \%)$ used forestry, one (3.85\%) used land laboratory, and one (3.85\%) used laboratory/other. One $(3.85 \%)$ did not teach the CSS. None of the respondents used biotechnology laboratory to teach the standard (see Table 10). 
Table 9

Methods Used to Teach Agribusiness CSS: Research Local Supply and Demand of Agricultural Products

\begin{tabular}{|c|c|c|c|}
\hline Location & Delivery & $\mathrm{f}$ & $\%$ \\
\hline Classroom & Project Based & 12 & 46.15 \\
\hline Classroom & Discussion & 9 & 34.62 \\
\hline Classroom & Inquiry & 7 & 26.92 \\
\hline Other & Library/computer lab & 7 & 26.92 \\
\hline Laboratory & Greenhouse & 6 & 23.08 \\
\hline Classroom & Lecture & 5 & 19.23 \\
\hline Classroom & Textbooks/handouts & 3 & 11.54 \\
\hline Laboratory & Meats laboratory & 3 & 11.54 \\
\hline Other & Do not Teach & 3 & 11.54 \\
\hline Classroom & Demonstration & 2 & 7.69 \\
\hline Laboratory & Mechanics laboratory & 1 & 3.85 \\
\hline Laboratory & Other & 1 & 3.85 \\
\hline Other & Field Trip & 1 & 3.85 \\
\hline Laboratory & Biotechnology laboratory & 0 & 0.00 \\
\hline Laboratory & Forestry & 0 & 0.00 \\
\hline Laboratory & Land laboratory & 0 & 0.00 \\
\hline
\end{tabular}


Table 10

Methods Used to Teach Agribusiness CSS: Return on Investment

\begin{tabular}{llll}
\hline Location & Delivery & $\mathrm{f}$ & $\%$ \\
\hline Classroom & Discussion & 10 & 38.46 \\
Classroom & Lecture & 10 & 38.46 \\
Classroom & Project Based & 9 & 34.62 \\
Classroom & Textbooks/handouts & 6 & 23.08 \\
Laboratory & Greenhouse & 6 & 23.08 \\
Other & Library/computer lab & 6 & 23.08 \\
Classroom & Inquiry & 5 & 19.23 \\
Classroom & Demonstration & 5 & 19.23 \\
Laboratory & Meats laboratory & 3 & 11.54 \\
Laboratory & Mechanics laboratory & 2 & 7.69 \\
Other & Field trip & 2 & 7.69 \\
Laboratory & Forestry & 1 & 3.85 \\
Laboratory & Land laboratory & 1 & 3.85 \\
Laboratory & Other & 1 & 3.85 \\
Other & Do not Teach & 1 & 3.85 \\
Laboratory & Biotechnology laboratory & 0 & 0.00 \\
\hline
\end{tabular}

\section{Supervised Agricultural Experience (SAE).}

Fourteen of the respondents $(53.85 \%)$ used the project-based method to teach the CSS: Supervised Agricultural Experience. Twelve (46.15\%) used classroom discussion, and $12(46.15 \%)$ used laboratory greenhouse to teach the CSS. Twelve (46.15\%) more used the library or computer lab to teach SAE. Ten of the respondents $(38.46 \%)$ used 
classroom inquiry, while six $(23.08 \%)$ used textbooks and/or handouts. Five respondents (19.23\%) used laboratory mechanics, and five (19.23\%) used field trips to teach the CSS. Four $(15.38 \%)$ used the meats laboratory and four (15.38\%) used other laboratory to teach. Three (11.54\%) used classroom demonstration, three (11.54\%) used land laboratory to teach the concept. Two respondents $(7.69 \%)$ used forestry in the laboratory to teach. One (3.85\%) used laboratory biotechnology, and one (3.85\%) does not teach the CSS (see Table 11).

Table 11

Methods Used to Teach Agribusiness CSS: Supervised Agricultural Experience (SAE)

\begin{tabular}{llll}
\hline Location & Method & $\mathrm{f}$ & $\%$ \\
\hline Classroom & Project Based & 14 & 53.85 \\
Classroom & Discussion & 12 & 46.15 \\
Laboratory & Greenhouse & 12 & 46.15 \\
Other & Library/computer lab & 12 & 46.15 \\
Classroom & Inquiry & 10 & 38.46 \\
Classroom & Textbooks/handouts & 6 & 23.08 \\
Laboratory & Mechanics laboratory & 5 & 19.23 \\
Other & Field trip & 5 & 19.23 \\
Laboratory & Meats laboratory & 4 & 15.38 \\
Laboratory & Other & 4 & 15.38 \\
Classroom & Demonstration & 3 & 11.54 \\
Laboratory & Land laboratory & 3 & 11.54 \\
Laboratory & Forestry & 2 & 7.69 \\
Laboratory & Biotechnology laboratory & 1 & 3.85 \\
Other & Do not Teach & 1 & 3.85 \\
\hline & & 5 & \\
\hline
\end{tabular}




\section{Four Ps.}

Thirteen of the respondents (50\%) used the lecture method to teach the Four Ps, while 12 of the respondents $(46.15 \%)$ used project-based method to teach the CSS. Eleven of the respondents (42.31\%) used discussion method. Six $(23.08 \%)$ used laboratory greenhouse while six (23.08\%) used classroom inquiry. Five (19.23\%) used classroom textbooks/handouts and five (19.23\%) used library or computer lab. Three (11.54\%) used classroom demonstration, and three (11.54\%) used mechanics laboratory to teach the CSS. Two (7.69\%) used a meats laboratory. One (3.85\%) used laboratory/other, and one $(3.85 \%)$ does not teach the CSS. None of the respondents used biotechnology laboratory, forestry, land laboratory or field trip to teach the CSS (see Table 12).

Table 12

Methods Used to Teach Agribusiness CSS: The Four Ps (product, place, price, and promotion)

\begin{tabular}{lllc}
\hline Location & Method & $\mathrm{f}$ & $\%$ \\
\hline Classroom & Lecture & 13 & 50 \\
Classroom & Project Based & 12 & 46.15 \\
Classroom & Discussion & 11 & 42.31 \\
Classroom & Inquiry & 6 & 23.08 \\
Laboratory & Greenhouse & 6 & 23.08 \\
Classroom & Textbooks/handouts & 5 & 19.23 \\
Other & Library/computer lab & 5 & 19.23 \\
Classroom & Demonstration & 3 & 11.54 \\
Laboratory & Mechanics laboratory & 3 & 11.54 \\
\hline
\end{tabular}


Table 12 (continued)

Methods Used to Teach Agribusiness CSS: The Four Ps (product, place, price, and promotion)

\begin{tabular}{llll}
\hline Location & Method & $\mathrm{f}$ & $\%$ \\
\hline Laboratory & Meats laboratory & 2 & 7.69 \\
Laboratory & Other & 1 & 3.85 \\
Other & Do not Teach & 1 & 3.85 \\
Laboratory & Biotechnology laboratory & 0 & 0.00 \\
Laboratory & Forestry & 0 & 0.00 \\
Laboratory & Land laboratory & 0 & 0.00 \\
Other & Field Trip & 0 & 0.00 \\
\hline
\end{tabular}

\section{Types of Agribusiness Ownership.}

Seventeen of the respondents (65.38\%) used project-based method of teaching to cover the CSS Types of Agribusiness Ownership. Fifteen of the respondents (57.69\%) used classroom discussion, while 12 (46.15\%) used classroom lecture. Nine of the respondents (34.62\%) used classroom textbooks/handouts. Eight (30.77\%) used a laboratory greenhouse, and eight (30.77\%) used a library or computer lab to teach the CSS. Seven of the respondents (26.92\%) used classroom inquiry as their preferred method, while six (23.08\%) used classroom demonstration. Four respondents (15.38\%) used a meats laboratory, and four (15.38\%) used a mechanics laboratory to teach the concept of types of agribusiness ownership. Three (11.54\%) used laboratory/other methods, and three (11.54\%) used field trips. Two respondents (7.69\%) used biotechnology laboratory, and two (7.69\%) used forestry. One respondent (3.85\%) used 
laboratory land, and one respondent (3.85\%) does not teach the concept of types of agribusiness ownership (see Table 13).

Table 13

Methods Used to Teach Agribusiness CSS: Types of Agribusiness Ownership

\begin{tabular}{|c|c|c|c|}
\hline Location & Method & $\mathrm{f}$ & $\%$ \\
\hline Classroom & Project Based & 17 & 65.38 \\
\hline Classroom & Discussion & 15 & 57.69 \\
\hline Classroom & Lecture & 12 & 46.15 \\
\hline Classroom & Textbooks/handouts & 9 & 34.62 \\
\hline Laboratory & Greenhouse & 8 & 30.77 \\
\hline Other & Library/computer lab & 8 & 30.77 \\
\hline Classroom & Inquiry & 7 & 26.92 \\
\hline Classroom & Demonstration & 6 & 23.08 \\
\hline Laboratory & Meats laboratory & 4 & 15.38 \\
\hline Laboratory & Mechanics laboratory & 4 & 15.38 \\
\hline Laboratory & Other & 3 & 11.54 \\
\hline Other & Field Trip & 3 & 11.54 \\
\hline Laboratory & Biotechnology laboratory & 2 & 7.69 \\
\hline Laboratory & Forestry & 2 & 7.69 \\
\hline Laboratory & Land laboratory & 1 & 3.85 \\
\hline Other & Do not Teach & 1 & 3.85 \\
\hline
\end{tabular}

Animal Cells.

Eight respondents (30.77\%) used textbooks/handouts to teach the CSS for Animal Cells. Seven of the respondents $(26.92 \%)$ used lecture. Six of the respondents $(23.06 \%)$ 
used inquiry, while five (19.23\%) used project-based learning experiences. Two of the respondents $(7.69 \%)$ used classroom demonstration for animal cells. One respondent $(3.85 \%)$ used Laboratory in a biotechnology laboratory, one $(3.85 \%)$ used library or computer lab, and one (3.85\%) used Laboratory in a meats lab to teach the CSS. None of the respondents identified used field trip, forestry, greenhouse, land laboratory, mechanics laboratory or other methods to teach about animal cells (see Table 14).

Table 14

Methods Used to Teach Animal Systems CSS: Animal Cells

\begin{tabular}{|c|c|c|c|}
\hline Location & Method & $\mathrm{f}$ & $\%$ \\
\hline Classroom & Textbooks/handouts & 8 & 30.77 \\
\hline Classroom & Lecture & 7 & 26.92 \\
\hline Classroom & Inquiry & 6 & 23.06 \\
\hline Classroom & Project Based & 5 & 19.23 \\
\hline Classroom & Demonstration & 2 & 7.69 \\
\hline Laboratory & Biotechnology laboratory & 1 & 3.85 \\
\hline Other & Library/computer lab & 1 & 3.85 \\
\hline Laboratory & Meats laboratory & 1 & 3.85 \\
\hline Other & Do not Teach & 0 & 0.00 \\
\hline Other & Field Trip & 0 & 0.00 \\
\hline Laboratory & Forestry & 0 & 0.00 \\
\hline Laboratory & Greenhouse & 0 & 0.00 \\
\hline Laboratory & Land laboratory & 0 & 0.00 \\
\hline Laboratory & Mechanics laboratory & 0 & 0.00 \\
\hline Laboratory & Other & 0 & 0.00 \\
\hline
\end{tabular}




\section{Animal Health Disorders.}

Ten respondents (38.46\%) used project-based methods to teach about Animal Health Disorders. Nine of the respondents (34.62\%) used textbooks and/or handouts. Eight of the respondents (30.77\%) used classroom discussion, and eight $(30.77 \%)$ used classroom lecture. Seven (26.92\%) used classroom inquiry, while five (19.23\%) used library and/or computer lab. One respondent (3.85\%) used classroom demonstration. None of the respondents used biotechnology laboratory, field trip, forestry, greenhouse, land laboratory, meats laboratory, mechanics laboratory, or other methods to teach about animal health disorders (see Table 15).

\section{Animal Welfare and Animal Rights.}

Thirteen of the respondents $(50 \%)$ used classroom discussion to teach about Animal Welfare and Animal Rights. Eight (30.77\%) used classroom lecture. Six of the respondents (23.08\%) used classroom inquiry, six (23.08\%) used project-based learning, and six (23.08\%) used textbooks/handouts to teach the CSS. Two (7.69\%) used demonstration, and two (7.69\%) used a meats laboratory to teach about animal welfare and animal rights. One (3.85\%) used field trips, and one $(3.85 \%)$ used library and/or computer lab. None of the respondents identified biotechnology laboratory, do not teach, forestry, greenhouse, land laboratory, mechanics laboratory, or other methods to teach the CSS about animal welfare and animal rights (see Table 16). 
Table 15

Methods Used to Teach Animal Systems CSS: Animal Health Disorders

\begin{tabular}{|c|c|c|c|}
\hline Location & Method & $\mathrm{f}$ & $\%$ \\
\hline Classroom & Project Based & 10 & 38.46 \\
\hline Classroom & Textbooks/handouts & 9 & 34.62 \\
\hline Classroom & Discussion & 8 & 30.77 \\
\hline Classroom & Lecture & 8 & 30.77 \\
\hline Classroom & Inquiry & 7 & 26.92 \\
\hline Other & Library/computer Lab & 5 & 19.23 \\
\hline Classroom & Demonstration & 1 & 3.85 \\
\hline Laboratory & Biotechnology laboratory & 0 & 0.00 \\
\hline Other & Do not Teach & 0 & 0.00 \\
\hline Other & Field Trip & 0 & 0.00 \\
\hline Laboratory & Forestry & 0 & 0.00 \\
\hline Laboratory & Greenhouse & 0 & 0.00 \\
\hline Laboratory & Land laboratory & 0 & 0.00 \\
\hline Laboratory & Meats laboratory & 0 & 0.00 \\
\hline Laboratory & Mechanics laboratory & 0 & 0.00 \\
\hline Laboratory & Other & 0 & 0.00 \\
\hline
\end{tabular}


Table 16

Methods Used to Teach Animal Systems CSS: Animal Welfare and Animal Rights

\begin{tabular}{|c|c|c|c|}
\hline Location & Method & $\mathrm{f}$ & $\%$ \\
\hline Classroom & Discussion & 13 & 50 \\
\hline Classroom & Lecture & 8 & 30.77 \\
\hline Classroom & Inquiry & 6 & 23.08 \\
\hline Classroom & Project Based & 6 & 23.08 \\
\hline Classroom & Textbooks/handouts & 6 & 23.08 \\
\hline Classroom & Demonstration & 2 & 7.69 \\
\hline Laboratory & Meats laboratory & 2 & 7.69 \\
\hline Other & Field Trip & 1 & 3.85 \\
\hline Other & Library/computer lab & 1 & 3.85 \\
\hline Laboratory & Biotechnology laboratory & 0 & 0.00 \\
\hline Other & Do not Teach & 0 & 0.00 \\
\hline Laboratory & Forestry & 0 & 0.00 \\
\hline Laboratory & Greenhouse & 0 & 0.00 \\
\hline Laboratory & Land laboratory & 0 & 0.00 \\
\hline Laboratory & Mechanics laboratory & 0 & 0.00 \\
\hline Laboratory & Other & 0 & 0.00 \\
\hline
\end{tabular}

\section{Basic Anatomy of Animals.}

Eight of the respondents (30.77\%) used discussion to cover the Basic Anatomy of Animals. Six respondents (23.08\%) used inquiry, six (23.08) used lecture, six (23.08\%) used project-based assignments, and six (23.08\%) used textbooks and/or handouts to cover the CSS. Five respondents (19.23\%) used demonstration, while four (15.38\%) used 
the meats lab. One respondent (3.85\%) used field trips to cover basic anatomy of animals. None of the respondents used the following methods to teach basic animal anatomy: biotechnology laboratory, forestry, greenhouse, land laboratory, library and/or computer lab, mechanics laboratory or other methods (see Table 17).

Table 17

Methods Used to Teach Animal Systems CSS: Basic Anatomy of Animals

\begin{tabular}{|c|c|c|c|}
\hline Location & Method & $\mathrm{f}$ & $\%$ \\
\hline Classroom & Discussion & 8 & 30.77 \\
\hline Classroom & Inquiry & 6 & 23.08 \\
\hline Classroom & Lecture & 6 & 23.08 \\
\hline Classroom & Project Based & 6 & 23.08 \\
\hline Classroom & Textbooks/handouts & 6 & 23.08 \\
\hline Classroom & Demonstration & 5 & 19.23 \\
\hline Laboratory & Meats laboratory & 4 & 15.38 \\
\hline Other & Field Trip & 1 & 3.85 \\
\hline Laboratory & Biotechnology laboratory & 0 & 0.00 \\
\hline Other & Do not teach & 0 & 0.00 \\
\hline Laboratory & Forestry & 0 & 0.00 \\
\hline Laboratory & Greenhouse & 0 & 0.00 \\
\hline Laboratory & Land laboratory & 0 & 0.00 \\
\hline Other & Library/Computer Lab & 0 & 0.00 \\
\hline Laboratory & Mechanics laboratory & 0 & 0.00 \\
\hline Laboratory & Other & 0 & 0.00 \\
\hline
\end{tabular}




\section{Bio-Security in the Animal Industry.}

Nine of the respondents (34.62\%) used classroom lecture to cover Bio-Security in the Animal Industry. Eight (30.77\%) used discussion, and eight (30.77\%) used textbooks and/or handouts to meet the requirements of the CSS. Five (19.23\%) used inquiry, while four $(15.38 \%)$ used project-based methods. Two $(7.69 \%)$ used demonstration, and two (7.69\%) used library and/or computer lab. One (3.85\%) used biotechnology laboratory, one (3.85\%) used a meats lab, and one (3.85\%) used other laboratory methods. None of the respondents used any of the following methods: field trip, forestry, greenhouse, land laboratory, or mechanics laboratory (see Table 18).

Table 18

Methods Used to Teach Animal Systems CSS: Bio-security in the Animal Industry

\begin{tabular}{llll}
\hline Location & Method & $\mathrm{f}$ & $\%$ \\
\hline Classroom & Lecture & 9 & 34.62 \\
Classroom & Discussion & 8 & 30.77 \\
Classroom & Textbooks/handouts & 8 & 30.77 \\
Classroom & Inquiry & 5 & 19.23 \\
Classroom & Project Based & 4 & 15.38 \\
Classroom & Demonstration & 2 & 7.69 \\
Other & Library/computer lab & 2 & 7.69 \\
Laboratory & Biotechnology laboratory & 1 & 3.85 \\
Laboratory & Meats laboratory & 1 & 3.85 \\
Laboratory & Other & 1 & 3.85 \\
\hline
\end{tabular}


Table 18 (continued)

Methods Used to Teach Animal Systems CSS: Bio-security in the Animal Industry

\begin{tabular}{llll}
\hline Location & Method & $\mathrm{f}$ & $\%$ \\
\hline Other & Do not Teach & 0 & 0.00 \\
Other & Field Trip & 0 & 0.00 \\
Laboratory & Forestry & 0 & 0.00 \\
Laboratory & Greenhouse & 0 & 0.00 \\
Laboratory & Land laboratory & 0 & 0.00 \\
Laboratory & Mechanics laboratory & 0 & 0.00 \\
\hline
\end{tabular}

\section{Breeds of Livestock.}

Ten of the respondents (38.46\%) used discussion as their preferred method to cover Breeds of Livestock. Nine (34.62\%) used project based learning. Eight (30.77\%) used lecture, and eight others (30.77\%) used textbooks and/or handouts for teaching breeds of livestock. Seven respondents (26.92\%) used library and/or computer lab. Six (23.08\%) used inquiry, while two (7.69\%) used field trips. One (3.85\%) used demonstration, and one (3.85\%) used a meats lab to teach the breeds of livestock. None of the respondents used biotechnology laboratory, forestry, greenhouse, land laboratory, mechanics laboratory, or other methods (see Table 19). 
Table 19

Methods Used to Teach Animal Systems CSS: Breeds of Livestock

\begin{tabular}{|c|c|c|c|}
\hline Location & Method & $\mathrm{f}$ & $\%$ \\
\hline Classroom & Discussion & 10 & 38.46 \\
\hline Classroom & Project Based & 9 & 34.62 \\
\hline Classroom & Lecture & 8 & 30.77 \\
\hline Classroom & Textbooks/handouts & 8 & 30.77 \\
\hline Other & Library/computer lab & 7 & 26.92 \\
\hline Classroom & Inquiry & 6 & 23.08 \\
\hline Other & Field Trip & 2 & 7.69 \\
\hline Classroom & Demonstration & 1 & 3.85 \\
\hline Laboratory & Meats laboratory & 1 & 3.85 \\
\hline Laboratory & Biotechnology laboratory & 0 & 0.00 \\
\hline Other & Do not Teach & 0 & 0.00 \\
\hline Laboratory & Forestry & 0 & 0.00 \\
\hline Laboratory & Greenhouse & 0 & 0.00 \\
\hline Laboratory & Land laboratory & 0 & 0.00 \\
\hline Laboratory & Mechanics laboratory & 0 & 0.00 \\
\hline Laboratory & Other & 0 & 0.00 \\
\hline
\end{tabular}

\section{Common and Scientific Names of Major Animal Species.}

Thirteen of the respondents $(50 \%)$ used the lecture method to teach the Common and Scientific Names of Major Animal Species. Eight (30.77\%) used textbooks and/or handouts. Six (23.08\%) used discussion, while five (19.23\%) used inquiry. Four (15.38\%) used project-based learning. Three (11.54\%) used library and/or computer lab 
as their method of instruction. One respondent (3.85\%) does not teach common and scientific names of major animal species and one (3.85\%) used field trip. None of the respondents used biotechnology laboratory, demonstration, forestry, greenhouse, meats laboratory, mechanics laboratory, or other types of methods to teach common and scientific names (see Table 20).

Table 20

Methods Used to Teach Animal Systems CSS: Common and Scientific Names of Major Animal Species.

\begin{tabular}{|c|c|c|c|}
\hline Location & Method & $\mathrm{f}$ & $\%$ \\
\hline Classroom & Lecture & 13 & 50 \\
\hline Classroom & Textbooks/handouts & 8 & 30.77 \\
\hline Classroom & Discussion & 6 & 23.08 \\
\hline Classroom & Inquiry & 5 & 19.23 \\
\hline Classroom & Project Based & 4 & 15.38 \\
\hline Other & Library/computer lab & 3 & 11.54 \\
\hline Other & Do not Teach & 1 & 3.85 \\
\hline Other & Field Trip & 1 & 3.85 \\
\hline Laboratory & Biotechnology laboratory & 0 & 0.00 \\
\hline Classroom & Demonstration & 0 & 0.00 \\
\hline Laboratory & Forestry & 0 & 0.00 \\
\hline Laboratory & Greenhouse & 0 & 0.00 \\
\hline Laboratory & Meats laboratory & 0 & 0.00 \\
\hline Laboratory & Mechanics laboratory & 0 & 0.00 \\
\hline Laboratory & Other & 0 & 0.00 \\
\hline
\end{tabular}




\section{Common Feedstuffs.}

Nine of the respondents (34.62\%) used lecture, nine (34.62\%) used project-based learning, and nine (34.62\%) used textbooks and/or handouts to teach Common Feedstuffs. Seven $(26.92 \%)$ used discussion, and seven more $(26.92 \%)$ used inquiry to teach the CSS. Six of the respondents (23.08\%) used demonstration. Two of the respondents (7.69\%) used library and/or computer lab, while one (3.85\%) used a meats lab to teach

common types of feedstuffs. None of the respondents used biotechnology laboratory, field trip, forestry, greenhouse, land laboratory, mechanics laboratory, or other methods (see Table 21).

\section{Issues of Animal Welfare and Animal Rights.}

Thirteen of the respondents $(50 \%)$ used classroom discussion to debate the Issues of Animal Welfare and Animal Rights. Six of the respondents $(23.08 \%)$ used classroom project-based learning. Five (19.23\%) used classroom inquiry, and five (19.23\%) used classroom textbooks and/or handouts. Four (15.38\%) used classroom lecture. Three (11.54\%) used the library and/or computer lab. Two (7.69\%) used classroom demonstration. One respondent (3.85\%) used laboratory biotechnology laboratory, and one $(3.85 \%)$ used a meats lab. One respondent $(3.85 \%)$ does not teach the concept, and one $(3.85 \%)$ used the mechanics laboratory to teach. None of the respondents used field trip, forestry, greenhouse, land laboratory, or other methods to teach animal welfare and animal rights (see Table 22). 
Table 21

Methods Used to Teach Animal Systems CSS: Common Types of Feedstuffs

\begin{tabular}{|c|c|c|c|}
\hline Location & Method & $\mathrm{f}$ & $\%$ \\
\hline Classroom & Lecture & 9 & 34.62 \\
\hline Classroom & Project Based & 9 & 34.62 \\
\hline Classroom & Textbooks/handouts & 9 & 34.62 \\
\hline Classroom & Discussion & 7 & 26.92 \\
\hline Classroom & Inquiry & 7 & 26.92 \\
\hline Classroom & Demonstration & 6 & 23.08 \\
\hline Other & Library/computer lab & 2 & 7.69 \\
\hline Laboratory & Meats laboratory & 1 & 3.85 \\
\hline Laboratory & Biotechnology laboratory & 0 & 0.00 \\
\hline Other & Do not Teach & 0 & 0.00 \\
\hline Other & Field Trip & 0 & 0.00 \\
\hline Laboratory & Forestry & 0 & 0.00 \\
\hline Laboratory & Greenhouse & 0 & 0.00 \\
\hline Laboratory & Land laboratory & 0 & 0.00 \\
\hline Laboratory & Mechanics laboratory & 0 & 0.00 \\
\hline Laboratory & Other & 0 & 0.00 \\
\hline
\end{tabular}


Table 22

Methods Used to Teach Animal Systems CSS: Debate the Issues Associated with Animal Welfare and Animal Rights

\begin{tabular}{|c|c|c|c|}
\hline Location & Method & $\mathrm{f}$ & $\%$ \\
\hline Classroom & Discussion & 13 & 50 \\
\hline Classroom & Project based & 6 & 23.08 \\
\hline Classroom & Inquiry & 5 & 19.23 \\
\hline Classroom & Textbooks/handouts & 5 & 19.23 \\
\hline Classroom & Lecture & 4 & 15.38 \\
\hline Other & Library/computer lab & 3 & 11.54 \\
\hline Classroom & Demonstration & 2 & 7.69 \\
\hline Laboratory & Biotechnology laboratory & 1 & 3.85 \\
\hline Other & Do not Teach & 1 & 3.85 \\
\hline Laboratory & Meats laboratory & 1 & 3.85 \\
\hline Laboratory & Mechanics laboratory & 1 & 3.85 \\
\hline Other & Field Trip & 0 & 0.00 \\
\hline Laboratory & Forestry & 0 & 0.00 \\
\hline Laboratory & Greenhouse & 0 & 0.00 \\
\hline Laboratory & Land laboratory & 0 & 0.00 \\
\hline Laboratory & Other & 0 & 0.00 \\
\hline
\end{tabular}

\section{Diagram the Typical Animal Cell.}

Eleven of the respondents (42.31\%) used classroom textbooks and/or handouts to Diagram the Typical Animal Cell. Eight of the respondents (30.77\%) used classroom project-based learning. Six of the respondents (23.08\%) used classroom lecture, five 
(19.23\%) used classroom inquiry, and four (15.38\%) used classroom discussion to diagram an animal cell. Two of the respondents (7.69\%) do not teach the concept of diagraming a typical animal cell. One respondent (3.85\%) used classroom demonstration, and one (3.85\%) used library and/or computer lab. None of the respondents used biotechnology laboratory, field trips, forestry, greenhouse, land laboratory, meats laboratory, mechanics laboratory, or other methods to diagram the typical animal cell (see Table 23).

Table 23

Methods Used to Teach Animal Systems CSS: Diagram a Typical Animal Cell and Identify the Organelles.

\begin{tabular}{llcc}
\hline Location & Method & $\mathrm{f}$ & $\%$ \\
\hline Classroom & Textbooks/handouts & 11 & 42.31 \\
Classroom & Project Based & 8 & 30.77 \\
Classroom & Lecture & 6 & 23.08 \\
Classroom & Inquiry & 5 & 19.23 \\
Classroom & Discussion & 4 & 15.38 \\
Other & Do not Teach & 2 & 7.69 \\
Classroom & Demonstration & 1 & 3.85 \\
Other & Library/computer lab & 1 & 3.85 \\
Laboratory & Biotechnology laboratory & 0 & 0.00 \\
Other & Field Trip & 0 & 0.00 \\
Laboratory & Forestry & 0 & 0.00 \\
Laboratory & Greenhouse & 0 & 0.00 \\
Laboratory & Land laboratory & 0 & 0.00 \\
Laboratory & Meats laboratory & 0 & 0.00 \\
Laboratory & Mechanics laboratory & 0 & 0.00 \\
Laboratory & Other & 0 & 0.00 \\
\hline
\end{tabular}




\section{Effects of Animal Agriculture on the Environment.}

Nine of the respondents (34.62\%) used classroom discussion to teach the Effects of Animal Agriculture on the Environment. Eight (30.77\%) used classroom lecture, and eight $(30.77 \%)$ used classroom project-based learning. Six of the respondents $(23.08 \%)$ used classroom textbooks and/or handouts, while five (19.23\%) used classroom inquiry. Two (7.69\%) used meats laboratory and one (3.85\%) used classroom demonstration. None of the respondents identified biotechnology laboratory, field trip, forestry, greenhouse, land laboratory, library/computer lab, mechanics laboratory, or other methods to teach the effects of animal agriculture on the environment (see Table 24).

Table 24

Methods of Teaching Animal Systems CSS: Effects of Animal Agriculture on the Environment

\begin{tabular}{llll}
\hline \multicolumn{1}{c}{ Location } & \multicolumn{1}{c}{ Method } & f & $\%$ \\
\hline Classroom & Discussion & 9 & 34.62 \\
Classroom & Lecture & 8 & 30.77 \\
Classroom & Project Based & 8 & 30.77 \\
Classroom & Textbooks/handouts & 6 & 23.08 \\
Classroom & Inquiry & 5 & 19.23 \\
Laboratory & Meats laboratory & 2 & 7.69 \\
Classroom & Demonstration & 1 & 3.85 \\
Laboratory & Biotechnology laboratory & 0 & 0.00 \\
Other & Do not Teach & 0 & 0.00 \\
Other & Field Trip & 0 & 0.00 \\
\hline
\end{tabular}


Table 24 (continued)

Methods of Teaching Animal Systems CSS: Effects of Animal Agriculture on the Environment

\begin{tabular}{llll}
\hline \multicolumn{1}{c}{ Location } & \multicolumn{1}{c}{ Method } & $\mathrm{f}$ & $\%$ \\
\hline Laboratory & Forestry & 0 & 0.00 \\
Laboratory & Greenhouse & 0 & 0.00 \\
Laboratory & Land laboratory & 0 & 0.00 \\
Other & Library/computer lab & 0 & 0.00 \\
Laboratory & Mechanics laboratory & 0 & 0.00 \\
Laboratory & Other & 0 & 0.00 \\
\hline
\end{tabular}

\section{Facilities Needed to House and Produce Animal Species Safely and}

\section{Efficiently.}

Nine $(34.62 \%)$ of the respondents used the classroom project-based learning method to teach Facilities Needed to House and Produce Animal Species Safely and Efficiently. Eight of the respondents (30.77\%) used classroom lecture. Six $(23.08 \%)$ of the respondents used classroom discussion, and another six (23.08\%) used classroom textbooks and/or handouts. Five (19.23\%) used classroom inquiry. Four respondents $(15.38 \%)$ used classroom demonstration while another four $(15.38 \%)$ used field trips to teach the CSS. One respondent (3.85\%) does not teach the CSS, one (3.85\%) used library and/or computer lab, and one (3.85\%) used a mechanics laboratory. None of the respondents used biotechnology laboratory, forestry, greenhouse, land laboratory, meats laboratory, or other methods to teach facilities needed to housed and produce animal species safely and efficiently (see Table 25). 
Table 25

Methods Used to Teach Animal Systems CSS: Facilities Needed to House and Produce Animal Species Safely and Efficiently

\begin{tabular}{|c|c|c|c|}
\hline Location & Method & $\mathrm{f}$ & $\%$ \\
\hline Classroom & Project Based & 9 & 34.62 \\
\hline Classroom & Lecture & 8 & 30.77 \\
\hline Classroom & Discussion & 6 & 23.08 \\
\hline Classroom & Textbooks/handouts & 6 & 23.08 \\
\hline Classroom & Inquiry & 5 & 19.23 \\
\hline Classroom & Demonstration & 4 & 15.38 \\
\hline Other & Field Trip & 4 & 15.38 \\
\hline Other & Do not Teach & 1 & 3.85 \\
\hline Other & Library/computer lab & 1 & 3.85 \\
\hline Laboratory & Mechanics laboratory & 1 & 3.85 \\
\hline Laboratory & Biotechnology laboratory & 0 & 0.00 \\
\hline Laboratory & Forestry & 0 & 0.00 \\
\hline Laboratory & Greenhouse & 0 & 0.00 \\
\hline Laboratory & Land laboratory & 0 & 0.00 \\
\hline Laboratory & Meats laboratory & 0 & 0.00 \\
\hline Laboratory & Other & 0 & 0.00 \\
\hline
\end{tabular}

\section{Livestock Terminology.}

Eleven respondents (42.31\%) used classroom lecture to teach Livestock

Terminology. Ten respondents (38.46\%) used classroom discussion. Eight respondents (30.77\%) used classroom textbooks and/or handouts, while seven respondents $(26.92 \%)$ 
used classroom project-based learning. Four (15.38\%) used classroom inquiry. One (3.85\%) used classroom demonstration, one (3.85\%) used field trips, and one $(3.85 \%)$ used library and/or computer lab. None of the respondents identified biotechnology laboratory, forestry, greenhouse, land laboratory, meats laboratory, mechanics laboratory, or other methods to teach livestock terminology (see Table 26).

Table 26

Methods Used to Teach Animal Systems CSS: Livestock Terminology

\begin{tabular}{llll}
\hline Location & Method & $\mathrm{f}$ & $\%$ \\
\hline Classroom & Lecture & 11 & 42.31 \\
Classroom & Discussion & 10 & 38.46 \\
Classroom & Textbooks/handouts & 8 & 30.77 \\
Classroom & Project Based & 7 & 26.92 \\
Classroom & Inquiry & 4 & 15.38 \\
Classroom & Demonstration & 1 & 3.85 \\
Other & Field Trip & 1 & 3.85 \\
Other & Library/computer lab & 1 & 3.85 \\
Laboratory & Biotechnology laboratory & 0 & 0.00 \\
Other & Do not Teach & 0 & 0.00 \\
Laboratory & Forestry & 0 & 0.00 \\
Laboratory & Greenhouse & 0 & 0.00 \\
Laboratory & Land laboratory & 0 & 0.00 \\
\hline Laboratory & Meats laboratory & 0 & 0.00 \\
\hline Laboratory & Other & 0 & 0.00 \\
\hline
\end{tabular}




\section{Perform a Basic Health Exam on a Live Animal.}

Eight respondents (30.77\%) used classroom demonstration to Perform a Basic Health Exam on a Live Animal. Six respondents (23.08\%) do not teach the basic health exam. Five respondents (19.23) used classroom project-based learning, and five (19.23\%) used classroom textbooks and/or handouts. Four respondents (15.38\%) used classroom lecture, and three (11.54\%) used classroom discussion. Two respondents (7.69\%) used field trips, and two (7.69\%) used classroom inquiry. One respondent (3.85\%) used library and/or computer lab, one (3.85\%) used mechanics laboratory, and one (3.85\%) used other laboratory methods. None of the respondents used biotechnology laboratory, forestry, greenhouse, land laboratory or meats labs to perform basic health exam on live animal (see Table 27).

Table 27

Methods Used to Teach Animal Systems CSS: Perform a Basic Health Exam on a Live Animal

\begin{tabular}{llll}
\hline Location & Method & $\mathrm{f}$ & $\%$ \\
\hline Classroom & Demonstration & 8 & 30.77 \\
Other & Do not Teach & 6 & 23.08 \\
Classroom & Project Based & 5 & 19.23 \\
Classroom & Textbooks/handouts & 5 & 19.23 \\
Classroom & Lecture & 4 & 15.38 \\
Classroom & Discussion & 3 & 11.54 \\
Other & Field Trip & 2 & 7.69 \\
Classroom & Inquiry & 2 & 7.69 \\
\hline
\end{tabular}


Table 27 (continued)

Methods Used to Teach Animal Systems CSS: Perform a Basic Health Exam on a Live Animal

\begin{tabular}{llll}
\hline Location & Method & $\mathrm{f}$ & $\%$ \\
\hline Other & Library/computer lab & 1 & 3.85 \\
Laboratory & Mechanics laboratory & 1 & 3.85 \\
Laboratory & Other & 1 & 3.85 \\
Laboratory & Biotechnology laboratory & 0 & 0.00 \\
Laboratory & Forestry & 0 & 0.00 \\
Laboratory & Greenhouse & 0 & 0.00 \\
Laboratory & Land laboratory & 0 & 0.00 \\
Laboratory & Meats laboratory & 0 & 0.00 \\
\hline
\end{tabular}

\section{Practice Administering Injections.}

Nine respondents (34.62\%) used classroom project-based learning to Practice Administering Injections. Six respondents (23.08\%) used demonstration. Four respondents (15.38\%) do not teach administering injections, and four (15.38\%) used classroom textbooks and/or handouts. Three respondents (11.54\%) used classroom discussion, and three (11.54\%) used classroom inquiry. Two respondents $(7.69 \%)$ used classroom lecture. One respondent (3.85\%) used field trips, one (3.85\%) used meats lab, and one (3.85\%) used other laboratory methods. None of the respondents used biotechnology laboratory, forestry, greenhouse, land laboratory, library and/or computer lab, or mechanics laboratory to practice administering injections (see Table 28). 
Table 28

Methods Used to Teach Animal Systems CSS: Practice Administering Injections

\begin{tabular}{llll}
\hline Location & Method & $\mathrm{f}$ & $\%$ \\
\hline Classroom & Project Based & 9 & 34.62 \\
Classroom & Demonstration & 6 & 23.08 \\
Other & Do not Teach & 4 & 15.38 \\
Classroom & Textbooks/handouts & 4 & 15.38 \\
Classroom & Discussion & 3 & 11.54 \\
Classroom & Inquiry & 3 & 11.54 \\
Classroom & Lecture & 2 & 7.69 \\
Other & Field Trip & 1 & 3.85 \\
Laboratory & Meats laboratory & 1 & 3.85 \\
Laboratory & Other & 1 & 3.85 \\
Laboratory & Biotechnology laboratory & 0 & 0.00 \\
Laboratory & Forestry & 0 & 0.00 \\
Laboratory & Greenhouse & 0 & 0.00 \\
Laboratory & Land laboratory & 0 & 0.00 \\
Other & Library/computer lab & 0 & \\
\hline Laboratory & & 0 & 0.00 \\
\hline
\end{tabular}

Origin, Significance, Distribution and Domestication of Animals.

Twelve respondents (46.15\%) used classroom lecture to teach the Origin, Significance, Distribution and Domestication of Animals. Nine respondents (34.62\%) used classroom discussion and nine (34.62\%) used classroom project based learning. Six respondents $(23.08 \%)$ used classroom textbooks and/or handouts. Three respondents 
(11.54\%) used classroom inquiry. Two respondents (7.69\%) used field trips and two (7.69\%) used library and/or computer lab. One respondent (3.85\%) used the meats laboratory. None of the respondents used biotechnology laboratory, demonstration, do not teach, forestry, greenhouse, land laboratory, mechanics laboratory, or other methods to teach the origin, significance, distribution, and domestication of animals (see Table 29).

Table 29

Methods Used to Teach Animal Systems CSS: The Origin, Significance, Distribution, and Domestication of Animals

\begin{tabular}{llcc}
\hline Location & Method & $\mathrm{f}$ & $\%$ \\
\hline Classroom & Lecture & 12 & 46.15 \\
Classroom & Discussion & 9 & 34.62 \\
Classroom & Project Based & 9 & 34.62 \\
Classroom & Textbooks/handouts & 6 & 23.08 \\
Classroom & Inquiry & 3 & 11.54 \\
Other & Field Trip & 2 & 7.69 \\
Other & Library/computer lab & 2 & 7.69 \\
Laboratory & Meats laboratory & 1 & 3.85 \\
Laboratory & Biotechnology laboratory & 0 & 0.00 \\
Classroom & Demonstration & 0 & 0.00 \\
Other & Do not Teach & 0 & 0.00 \\
Laboratory & Forestry & 0 & 0.00 \\
Laboratory & Greenhouse & 0 & 0.00 \\
Laboratory & Land laboratory & 0 & 0.00 \\
Laboratory & Mechanics laboratory & 0 & 0.00 \\
Laboratory & Other & 0 & 0.00 \\
\hline
\end{tabular}




\section{Agricultural Innovations in Agricultural Biotechnology.}

Eight respondents $(30.77 \%)$ used the discussion method in the classroom to teach Agricultural Innovations in Agricultural Biotechnology. Seven (26.92\%) used textbooks and handouts. Five respondents (19.23\%) used classroom inquiry, five (19.23\%) used classroom lecture, and five (19.23\%) used classroom project-based learning. Four (15.38\%) used the library and/or computer lab to teach the CSS. Three (11.54\%) used biotechnology laboratory or supervised practice, while two respondents $(7.69 \%)$ do not teach the concept. One respondent (3.85\%) used classroom demonstration, one $(3.85 \%)$ used the greenhouse laboratory, one (3.85\%) used the meats laboratory and one $(3.85 \%)$ used other methods in the laboratory or supervised practice. None of the respondents used field trips, forestry, land laboratory, or mechanics laboratory to teach the concept (see Table 30).

Table 30

Methods Used to Teach Agriculture Innovations: Agricultural Biotechnology

\begin{tabular}{lllc}
\hline Location & Method & $\mathrm{f}$ & $\%$ \\
\hline Classroom & Discussion & 8 & 30.77 \\
Classroom & Textbooks/handouts & 7 & 26.92 \\
Classroom & Inquiry & 5 & 19.23 \\
Classroom & Lecture & 5 & 19.23 \\
Classroom & Project Based & 5 & 19.23 \\
Other & Library/computer lab & 4 & 15.38 \\
Laboratory & Biotechnology laboratory & 3 & 11.54 \\
Other & Do not Tech & 2 & 7.69 \\
\hline
\end{tabular}


Table 30 (continued)

Methods Used to Teach Agriculture Innovations: Agricultural Biotechnology

\begin{tabular}{llll}
\hline Location & Method & $\mathrm{f}$ & $\%$ \\
\hline Classroom & Demonstration & 1 & 3.85 \\
Laboratory & Greenhouse & 1 & 3.85 \\
Laboratory & Meats laboratory & 1 & 3.85 \\
Laboratory & Other & 1 & 3.85 \\
Other & Field Trip & 0 & 0.00 \\
Laboratory & Forestry & 0 & 0.00 \\
Laboratory & Land laboratory & 0 & 0.00 \\
Laboratory & Mechanics laboratory & 0 & 0.00 \\
\hline
\end{tabular}

\section{Applications of Biotechnology in Agriculture.}

Eleven respondents (42.31\%) used classroom discussion to teach Applications of Biotechnology in Agriculture. Five respondents (19.23\%) used classroom textbooks and/or handouts. Four respondents (15.38\%) used classroom inquiry, four (15.38\%) used classroom lecture, and four (15.38\%) used classroom project based learning. Three respondents (11.54\%) used laboratory and/or supervised practice in biotechnology and three (11.54\%) used library and/or computer lab. Two respondents (7.69\%) do not teach the concept and one respondent (3.85\%) used classroom demonstration. None of the respondents used forestry, field trip, greenhouse, land laboratory, meats laboratory, mechanics laboratory or other Laboratory methods (see Table 31). 
Table 31

Methods Used to Teach Agricultural Innovations: Applications of Biotechnology in Agriculture

\begin{tabular}{|c|c|c|c|}
\hline Location & Method & $\mathrm{f}$ & $\%$ \\
\hline Classroom & Discussion & 11 & 42.31 \\
\hline Classroom & Textbooks/handouts & 5 & 19.23 \\
\hline Classroom & Inquiry & 4 & 15.38 \\
\hline Classroom & Lecture & 4 & 15.38 \\
\hline Classroom & Project Based & 4 & 15.38 \\
\hline Laboratory & Biotechnology laboratory & 3 & 11.54 \\
\hline Other & Library/computer lab & 3 & 11.54 \\
\hline Other & Do not Teach & 2 & 7.69 \\
\hline Classroom & Demonstration & 1 & 3.85 \\
\hline Other & Field Trip & 0 & 0.00 \\
\hline Laboratory & Forestry & 0 & 0.00 \\
\hline Laboratory & Greenhouse & 0 & 0.00 \\
\hline Laboratory & Land laboratory & 0 & 0.00 \\
\hline Laboratory & Meats laboratory & 0 & 0.00 \\
\hline Laboratory & Mechanics laboratory & 0 & 0.00 \\
\hline
\end{tabular}

\section{Issues Associated with Biotechnology.}

Thirteen respondents (50\%) used classroom discussion to debate the Issues Associated with Biotechnology. Six respondents (23.08\%) used classroom textbooks and/or handouts. Five respondents (19.23\%) used classroom lecture. Three respondents (11.54\%) used classroom project based learning. Two respondents $(7.69 \%)$ used 
classroom demonstration, two (7.69\%) do not have students debate issues associated with biotechnology, and two (7.69\%) used classroom inquiry. One respondent $(3.85 \%)$ used biotechnology in a laboratory and/or supervised practice, and one $(3.85 \%)$ used the library and/or computer lab to debate the issues associated with biotechnology. None of the respondents used field trip, forestry, greenhouse, land laboratory, meats laboratory, mechanics laboratory or other laboratory and/or supervised practice methods (see Table $32)$.

Table 32

Methods Used to Teach Agricultural Innovations CSS: Debate the Issues Associated with Biotechnology

\begin{tabular}{llcc}
\hline Location & Method & $\mathrm{f}$ & $\%$ \\
\hline Classroom & Discussion & 13 & 50 \\
Classroom & Textbooks/handouts & 6 & 23.08 \\
Classroom & Lecture & 5 & 19.23 \\
Classroom & Project Based & 3 & 11.54 \\
Classroom & Demonstration & 2 & 7.69 \\
Other & Do not Teach & 2 & 7.69 \\
Classroom & Inquiry & 2 & 7.69 \\
Laboratory & Biotechnology laboratory & 1 & 3.85 \\
Other & Library/computer lab & 1 & 3.85 \\
Other & Field Trip & 0 & 0.00 \\
Laboratory & Forestry & 0 & 0.00 \\
Laboratory & Greenhouse & 0 & 0.00 \\
Laboratory & Land laboratory & 0 & 0.00 \\
Laboratory & Meats laboratory & 0 & 0.00 \\
Laboratory & Mechanics laboratory & 0 & 0.00 \\
Laboratory & Other & 0 & 0.00 \\
\hline
\end{tabular}




\section{Current Agricultural Products Impacted by Biotechnology Practices.}

Six respondents (23.08\%) used the library and/or computer lab, and six (23.08\%) used classroom project-based learning to research Current Agricultural Products Impacted by Biotechnology Practices. Five respondents (19.23\%) used classroom discussion, and five (19.23\%) used classroom textbooks and/or handouts. Four respondents $(15.38 \%)$ used classroom inquiry. Three respondents $(11.54 \%)$ do not teach how current agricultural practices are impacted by biotechnology practices, and three (11.54\%) used classroom lecture. One respondent (3.85\%) used the greenhouse laboratory and/or supervised practice to research current agricultural products impacted by biotechnology practices. None of the respondents used biotechnology laboratory, classroom demonstration, field trip, forestry, land laboratory, meats laboratory or mechanics laboratory to teach the concept (see Table 33).

Table 33

Methods Used to Teach Agricultural Innovations CSS: Research Current Agricultural Products Impacted by Biotechnology Practices

\begin{tabular}{lllc}
\hline Location & Method & $\mathrm{f}$ & $\%$ \\
\hline Other & Library/computer lab & 6 & 23.08 \\
Classroom & Project Based & 6 & 23.08 \\
Classroom & Discussion & 5 & 19.23 \\
Classroom & Textbooks/handouts & 5 & 19.23 \\
Classroom & Inquiry & 4 & 15.38 \\
Other & Do not teach & 3 & 11.54 \\
Classroom & Lecture & 3 & 11.54 \\
Laboratory & Greenhouse & 1 & 3.85 \\
\hline
\end{tabular}


Table 33 (continued)

Methods Used to Teach Agricultural Innovations CSS: Research Current Agricultural Products Impacted by Biotechnology Practices

\begin{tabular}{llll}
\hline Location & Method & $\mathrm{f}$ & $\%$ \\
\hline Laboratory & Biotechnology laboratory & 0 & 0.00 \\
Classroom & Demonstration & 0 & 0.00 \\
Other & Field Trip & 0 & 0.00 \\
Laboratory & Forestry & 0 & 0.00 \\
Laboratory & Land laboratory & 0 & 0.00 \\
Laboratory & Meats laboratory & 0 & 0.00 \\
Laboratory & Mechanics laboratory & 0 & 0.00 \\
Laboratory & Other & 0 & 0.00 \\
\hline
\end{tabular}

\section{History of Agricultural Innovation.}

Ten respondents (38.46\%) used classroom textbooks and/or handouts to teach the History of Agricultural Innovation. Nine respondents (34.62\%) used classroom discussion. Eight respondents (30.77\%) used classroom lecture. Four respondents (15.38\%) used classroom inquiry. Three respondents (11.54\%) used classroom projectbased learning, and three (11.54\%) used library and/or computer lab. One respondent (3.85\%) used biotechnology in the laboratory and/or supervised practice, one $(3.85 \%)$ does not teach the history of agricultural innovation, one $(3.85 \%)$ used laboratory and/or supervised practice in the greenhouse, and one $(3.85 \%)$ used the meats lab. None of the respondents used classroom demonstration, field trip, forestry, land laboratory, 
mechanics laboratory, other laboratory and/or supervised practice methods (see Table $34)$.

Table 34

Methods Used to Teach Agricultural Innovations CSS: The History of Agriculture Innovation

\begin{tabular}{|c|c|c|c|}
\hline Location & Method & $\mathrm{f}$ & $\%$ \\
\hline Classroom & Textbooks/handouts & 10 & 38.46 \\
\hline Classroom & Discussion & 9 & 34.62 \\
\hline Classroom & Lecture & 8 & 30.77 \\
\hline Classroom & Inquiry & 4 & 15.38 \\
\hline Other & Library/computer lab & 3 & 11.54 \\
\hline Classroom & Project Based & 3 & 11.54 \\
\hline Laboratory & Biotechnology laboratory & 1 & 3.85 \\
\hline Other & Do not Teach & 1 & 3.85 \\
\hline Laboratory & Greenhouse & 1 & 3.85 \\
\hline Laboratory & Meats laboratory & 1 & 3.85 \\
\hline Classroom & Demonstration & 0 & 0.00 \\
\hline Other & Field Trip & 0 & 0.00 \\
\hline Laboratory & Forestry & 0 & 0.00 \\
\hline Laboratory & Land laboratory & 0 & 0.00 \\
\hline Laboratory & Mechanics laboratory & 0 & 0.00 \\
\hline Laboratory & Other & 0 & 0.00 \\
\hline
\end{tabular}




\section{Major Agriculture Inventions and Their Impact on the Industry.}

Eleven respondents (42.31\%) used classroom discussion to teach Major Agriculture Inventions and Their Impact on the Industry. Eight respondents (30.77\%) used classroom textbooks and/or handouts. Six respondents (23.08\%) used classroom lecture. Five respondents (19.23\%) used classroom inquiry. Three respondents $(11.54 \%)$ used library and/or computer lab, and three (11.54\%) used classroom project-based learning. One respondent $(3.85 \%)$ does not teach about inventions and their impact, and one $(3.85 \%)$ used the mechanics laboratory. None of the respondents used biotechnology laboratory, demonstration, field trip, forestry, greenhouse, land laboratory, meats laboratory or other laboratory methods.

Table 35

Methods Used to Teach Agriculture Innovations CSS: The Major Agriculture Inventions and Their Impact on the Industry

\begin{tabular}{llll}
\hline Location & Method & $\mathrm{f}$ & $\%$ \\
\hline Classroom & Discussion & 11 & 42.31 \\
Classroom & Textbooks/handouts & 8 & 30.77 \\
Classroom & Lecture & 6 & 23.08 \\
Classroom & Inquiry & 5 & 19.23 \\
Other & Library/computer lab & 3 & 11.54 \\
Classroom & Project Based & 3 & 11.54 \\
Other & Do not Teach & 1 & 3.85 \\
Laboratory & Mechanics laboratory & 1 & 3.85 \\
Laboratory & Biotechnology laboratory & 0 & 0.00 \\
\hline
\end{tabular}


Table 35 (continued)

Methods Used to Teach Agriculture Innovations CSS: The Major Agriculture Inventions and Their Impact on the Industry

\begin{tabular}{llll}
\hline Location & Method & $\mathrm{f}$ & $\%$ \\
\hline Classroom & Demonstration & 0 & 0.00 \\
Other & Field Trip & 0 & 0.00 \\
Laboratory & Forestry & 0 & 0.00 \\
Laboratory & Greenhouse & 0 & 0.00 \\
Laboratory & Land laboratory & 0 & 0.00 \\
Laboratory & Meats laboratory & 0 & 0.00 \\
Laboratory & Other & 0 & 0.00 \\
\hline
\end{tabular}

\section{Agricultural Related Technology and Equipment.}

Seven respondents (26.92\%) used classroom discussion to teach about Agricultural Related Technology and Equipment. Six respondents (23.08\%) used classroom project-based learning, and six (23.08\%) used classroom textbooks and/or handouts. Three respondents (11.54\%) used classroom lecture and three (11.54\%) used a library and/or computer lab. Two respondents (7.69\%) do not teach about agricultural related technology and equipment, two (7.69\%) used laboratory and/or supervised practice in a greenhouse, two (7.69\%) used classroom inquiry, and two (7.69\%) used a mechanics laboratory. One respondent (3.85\%) used a biotechnology laboratory, one (3.85\%) used classroom demonstration, and one (3.85\%) used field trip. None of the respondents used forestry, land laboratory, or other laboratory and/or supervised practice methods (see Table 36). 
Table 36

Methods Used to Teach Agriculture Innovations CSS: Used Agricultural Related Technology and Equipment

\begin{tabular}{|c|c|c|c|}
\hline Location & Method & $\mathrm{f}$ & $\%$ \\
\hline Classroom & Discussion & 7 & 26.92 \\
\hline Classroom & Project Based & 6 & 23.08 \\
\hline Classroom & Textbooks/handouts & 6 & 23.08 \\
\hline Classroom & Lecture & 3 & 11.54 \\
\hline Classroom & Library/computer lab & 3 & 11.54 \\
\hline Other & Do not Teach & 2 & 7.69 \\
\hline Laboratory & Greenhouse & 2 & 7.69 \\
\hline Classroom & Inquiry & 2 & 7.69 \\
\hline Laboratory & Mechanics laboratory & 2 & 7.69 \\
\hline Laboratory & Biotechnology laboratory & 1 & 3.85 \\
\hline Classroom & Demonstration & 1 & 3.85 \\
\hline Other & Field trip & 1 & 3.85 \\
\hline Laboratory & Meats laboratory & 1 & 3.85 \\
\hline Laboratory & Forestry & 0 & 0.00 \\
\hline Laboratory & Land laboratory & 0 & 0.00 \\
\hline Laboratory & Other & 0 & 0.00 \\
\hline
\end{tabular}

\section{Common Weights and Measures Used in the Food Products and Processing}

Industry.

Eight respondents (30.77\%) used classroom discussion and eight respondents $(30.77 \%)$ classroom lecture to teach the Common Weights and Measures Used in the 
Food Products and Processing Industry. Six respondents (23.08\%) used classroom textbooks and/or handouts. Four respondents (15.38\%) used classroom demonstration while three respondents (11.54\%) do not teach weights and measures. Two respondents (7.69\%) used classroom project based learning, two (7.69\%) used classroom inquiry and two (7.69\%) used the meats laboratory and/or supervised practice. One respondent (3.85\%) used laboratory and/or supervised practice in the greenhouse, one respondent (3.85\%) used other laboratory and/or supervised practice using other methods, and one (3.85\%) used library and/or computer lab. None of the respondents used biotechnology laboratory, forestry, land laboratory, mechanics laboratory, or field trips to teach common weights and measures in the food products and processing industry (see Table 37).

Table 37

Methods Used to Teach Food Products and Processing CSS: Common Weights and Measures in the Food Products and Processing Industry

\begin{tabular}{llll}
\hline Location & Method & $\mathrm{f}$ & $\%$ \\
\hline Classroom & Discussion & 8 & 30.77 \\
Classroom & Lecture & 8 & 30.77 \\
Classroom & Textbooks/handouts & 6 & 23.08 \\
Classroom & Demonstration & 4 & 15.38 \\
Other & Do not Teach & 3 & 11.54 \\
Classroom & Project Based & 2 & 7.69 \\
Classroom & Inquiry & 2 & 7.69 \\
Laboratory & Meats laboratory & 2 & 7.69 \\
Laboratory & Greenhouse & 1 & 3.85 \\
Laboratory & Other & 1 & 3.85 \\
\hline
\end{tabular}


Table 37 (continued)

Methods Used to Teach Food Products and Processing CSS: Common Weights and Measures in the Food Products and Processing Industry

\begin{tabular}{llll}
\hline Location & Method & $\mathrm{f}$ & $\%$ \\
\hline Other & Library/computer lab & 1 & 3.85 \\
Laboratory & Biotechnology laboratory & 0 & 0.00 \\
Laboratory & Forestry & 0 & 0.00 \\
Laboratory & Land laboratory & 0 & 0.00 \\
Laboratory & Mechanics laboratory & 0 & 0.00 \\
Other & Field Trip & 0 & 0.00 \\
\hline
\end{tabular}

\section{Compare and Contrast Various Food Labels.}

Seven respondents $(26.92 \%)$ used classroom discussion to Compare and Contrast Various Food Labels. Four respondents (15.38\%) used classroom project-based learning. Four respondents (15.38\%) used classroom inquiry. Four respondents (15.38\%) used classroom demonstration. Four respondents (15.38\%) used classroom lecture. Four respondents (15.38\%) used classroom textbooks and/or handouts. Four respondents (15.38\%) used the meats laboratory and/or supervised practice. Three respondents $(11.54 \%)$ do not teach about food labels. One respondent $(3.85 \%)$ used other methods in the laboratory and/or supervised practice, and one respondent $(3.85 \%)$ used the library and/or computer lab. None of the respondents used mechanics laboratory, greenhouse, biotechnology laboratory, land laboratory, forestry or field trip to compare and contrast various food labels (see Table 38). 
Table 38

Methods Used to Teach Food Products and Processing CSS: Compare and Contrast Various Food Labels

\begin{tabular}{|c|c|c|c|}
\hline Location & Method & $\mathrm{f}$ & $\%$ \\
\hline Classroom & Discussion & 7 & 26.92 \\
\hline Classroom & Project based & 4 & 15.38 \\
\hline Classroom & Inquiry & 4 & 15.38 \\
\hline Classroom & Demonstration & 4 & 15.38 \\
\hline Classroom & Lecture & 4 & 15.38 \\
\hline Classroom & Textbooks/handouts & 4 & 15.38 \\
\hline Laboratory & Meats laboratory & 4 & 15.38 \\
\hline Other & Do not Teach & 3 & 11.54 \\
\hline Laboratory & Other & 1 & 3.85 \\
\hline Other & Library/computer lab & 1 & 3.85 \\
\hline Laboratory & Mechanics laboratory & 0 & 0.00 \\
\hline Laboratory & Greenhouse & 0 & 0.00 \\
\hline Laboratory & Biotechnology laboratory & 0 & 0.00 \\
\hline Laboratory & Land laboratory & 0 & 0.00 \\
\hline Laboratory & Forestry & 0 & 0.00 \\
\hline Other & Field Trip & 0 & 0.00 \\
\hline
\end{tabular}

\section{Conducting a Food Preservation Experiment.}

Eight respondents (30.77\%) do not teach the concept of Conducting a Food Preservation Experiment. Seven respondents (26.92\%) used classroom project-based learning. Two respondents $(7.69 \%)$ used classroom demonstration. Two respondents 
(7.69\%) used classroom lecture. Two respondents $(7.69 \%)$ used the meats laboratory and/or supervised practice. One respondent (3.85\%) used classroom inquiry. One respondent (3.85\%) used classroom discussion. One respondent (3.85\%) used classroom textbooks and/or handouts. One respondent (3.85\%) used other laboratory methods and/or supervised practice. None of the respondents used mechanics laboratory, greenhouse, biotechnology laboratory, land laboratory, forestry, library and/or computer lab or field trip to conduct a food preservation experiment (see Table 39).

Table 39

Methods Used to Teach Food Products and Processing CSS: Conduct a Food Preservation Experiment

\begin{tabular}{llll}
\hline Location & Method & $\mathrm{f}$ & $\%$ \\
\hline Other & Do not Teach & 8 & 30.77 \\
Classroom & Project Based & 7 & 26.92 \\
Classroom & Demonstration & 2 & 7.69 \\
Classroom & Lecture & 2 & 7.69 \\
Laboratory & Meats laboratory & 2 & 7.69 \\
Classroom & Inquiry & 1 & 3.85 \\
Classroom & Discussion & 1 & 3.85 \\
Classroom & Textbooks/handouts & 1 & 3.85 \\
Laboratory & Other & 1 & 3.85 \\
Laboratory & Mechanics laboratory & 0 & 0.00 \\
Laboratory & Greenhouse & 0 & 0.00 \\
Laboratory & Biotechnology laboratory & 0 & 0.00 \\
\hline
\end{tabular}


Table 39 (continued)

Methods Used to Teach Food Products and Processing CSS: Conduct a Food Preservation Experiment

\begin{tabular}{llll}
\hline Location & Method & $\mathrm{f}$ & $\%$ \\
\hline Laboratory & Land laboratory & 0 & 0.00 \\
Laboratory & Forestry & 0 & 0.00 \\
Other & Library/computer lab & 0 & 0.00 \\
Other & Field trip & 0 & 0.00 \\
\hline
\end{tabular}

Foods Derived from Meat, Egg, Poultry, Fish, and Dairy Products.

Nine respondents $(34.62 \%)$ used classroom discussion to teach the concept of Foods Derived from Meat, Egg, Poultry, Fish, and Dairy Products. Seven respondents (26.92\%) used classroom lecture, and seven (26.92\%) used classroom textbooks and/or handouts. Six respondents (23.08\%) used classroom project based learning. Four respondents (15.38\%) used classroom inquiry. Three respondents $(11.54 \%)$ used meats laboratories and/or supervised practice. One respondent (3.85\%) used classroom demonstration. One respondent $(3.85 \%)$ used other methods in the laboratory and/or supervised practice. None of the respondents used mechanics laboratory, greenhouse, biotechnology laboratory, land laboratory, forestry, library and/or computer lab (see Table 40). 
Table 40

Methods Used to Teach Food Products and Processing CSS: Foods Derived from Meat. Egg, Poultry, Fish and Dairy Products

\begin{tabular}{llll}
\hline Location & Method & $\mathrm{f}$ & $\%$ \\
\hline Classroom & Discussion & 9 & 34.62 \\
Classroom & Lecture & 7 & 26.92 \\
Classroom & Textbooks & 7 & 26.92 \\
Classroom & Project Based & 6 & 23.08 \\
Classroom & Inquiry & 4 & 15.38 \\
Laboratory & Meats laboratory & 3 & 11.54 \\
Classroom & Demonstration & 1 & 3.85 \\
Laboratory & Other & 1 & 3.85 \\
Laboratory & Mechanics laboratory & 0 & 0.00 \\
Laboratory & Greenhouse & 0 & 0.00 \\
Laboratory & Biotechnology laboratory & 0 & 0.00 \\
Laboratory & Land laboratory & 0 & 0.00 \\
Laboratory & Forestry & 0 & 0.00 \\
Other & Library/computer lab & 0 & 0.00 \\
\hline Other & Do neach & 0 & 0.00 \\
\hline
\end{tabular}

Methods of Food Preservations.

Eight respondents (30.77\%) used classroom project-based learning and eight (30.77\%) used classroom lecture to teach Methods of Food Preservation. Five respondents (19.23\%) used classroom discussion. Five respondents (19.23\%) used 
classroom demonstration. Five respondents (19.23\%) used the meats laboratory and/or supervised practice. Three respondents (11.54\%) used classroom inquiry. Three respondents (11.54\%) used classroom textbooks and/or handouts. Three respondents $(11.54 \%)$ do not teach methods of food preservation. One respondent $(3.85 \%)$ used other methods in the laboratory and/or supervised practice. None of the respondents used mechanics laboratory, greenhouse, biotechnology laboratory, land laboratory, forestry, library and/or computer lab, or field trip (see table 41).

Table 41

Methods Used to Teach Food Products and Processing CSS: Methods of Food Preservation

\begin{tabular}{llll}
\hline Location & Methods & $\mathrm{f}$ & $\%$ \\
\hline Classroom & Project Based & 8 & 30.77 \\
Classroom & Lecture & 8 & 30.77 \\
Classroom & Discussion & 5 & 19.23 \\
Classroom & Demonstration & 5 & 19.23 \\
Laboratory & Meats laboratory & 5 & 19.23 \\
Classroom & Inquiry & 3 & 11.54 \\
Classroom & Textbooks/handouts & 3 & 11.54 \\
Other & Do not Teach & 3 & 11.54 \\
Laboratory & Other & 1 & 3.85 \\
Laboratory & Mechanics laboratory & 0 & 0.00 \\
Laboratory & Greenhouse & 0 & 0.00 \\
Laboratory & Biotechnology laboratory & 0 & 0.00 \\
Laboratory & Land laboratory & 0 & 0.00 \\
Laboratory & Forestry & 0 & 0.00 \\
Other & Library/computer lab & 0 & 0.00 \\
Other & Field Trip & 0 & 0.00 \\
\hline
\end{tabular}




\section{Produce a Food Product Such As Cheese, Sausage, or Sauerkraut.}

Ten respondents (38.46\%) used classroom project-based learning to Produce a Food Product such as Cheese, Sausage, or Sauerkraut. Seven respondents (26.92\%) used classroom demonstration. Six respondents $(23.08 \%)$ used the meats laboratory and/or supervised practice. Five respondents (19.23\%) used classroom lecture. Four respondents $(15.38 \%)$ used classroom textbooks and/or handouts. Three respondents $(11.54 \%)$ used classroom discussion and three (11.54\%) do not teach producing a food product. One respondent $(3.85 \%)$ used classroom inquiry. One respondent $(3.85 \%)$ used other methods in the laboratory and/or supervised practice. None of the respondents used mechanics laboratory, greenhouse, biotechnology laboratory, land laboratory, forestry, library and/or computer lab or field trips (see Table 42).

Table 42

Methods Used to Teach Food Products and Processing CSS: Produce a Food Product (Cheese, Sausage, Sauerkraut, etc.)

\begin{tabular}{lllc}
\hline Location & Method & $\mathrm{f}$ & $\%$ \\
\hline Classroom & Project Based & 10 & 38.46 \\
Classroom & Demonstration & 7 & 26.92 \\
Laboratory & Meats laboratory & 6 & 23.08 \\
Classroom & Lecture & 5 & 19.23 \\
Classroom & Textbooks/handouts & 4 & 15.38 \\
Classroom & Discussion & 3 & 11.54 \\
Other & Do not Teach & 3 & 11.54 \\
Classroom & Inquiry & 1 & 3.85 \\
Laboratory & Other & 1 & 3.85 \\
\hline
\end{tabular}


Table 42 (continued)

Methods Used to Teach Food Products and Processing CSS: Produce a Food Product (Cheese, Sausage, Sauerkraut, etc.)

\begin{tabular}{llll}
\hline Location & Method & $\mathrm{f}$ & $\%$ \\
\hline Laboratory & Mechanics laboratory & 0 & 0.00 \\
Laboratory & Greenhouse & 0 & 0.00 \\
Laboratory & Biotechnology laboratory & 0 & 0.00 \\
Laboratory & Land laboratory & 0 & 0.00 \\
Laboratory & Forestry & 0 & 0.00 \\
Other & Library/computer lab & 0 & 0.00 \\
Other & Field Trip & 0 & 0.00 \\
\hline
\end{tabular}

\section{Products Derived From Fruits and Vegetables.}

Ten respondents (38.46\%) used classroom discussion to teach Products Derived from Fruits and Vegetables. Nine respondents (34.62\%) used classroom lecture. Seven respondents $(26.92 \%)$ used classroom textbooks and/or handouts. Five respondents (19.23\%) used classroom project based learning. Four respondents (15.38\%) used classroom inquiry. One respondent (3.85\%) used classroom demonstration. One respondent (3.85\%) used the greenhouse laboratory and/or supervised practice. One respondent $(3.85 \%)$ used the meats laboratory and/or supervised practice. One respondent (3.85\%) used other methods in the laboratory and/or supervised practice. One respondent $(3.85 \%)$ used the library and/or computer lab. One respondent $(3.85 \%)$ does not teach about products derived from fruits and vegetables. None of the respondents used 
mechanics laboratory, biotechnology laboratory, land laboratory, forestry, or field trip to teach products derived from fruits and vegetables (see Table 43).

Table 43

Methods Used to Teach Food Products and Processing CSS: Products Derived from Fruits and Vegetables

\begin{tabular}{|c|c|c|c|}
\hline Location & Method & $\mathrm{f}$ & $\%$ \\
\hline Classroom & Discussion & 10 & 38.46 \\
\hline Classroom & Lecture & 9 & 34.62 \\
\hline Classroom & Textbooks/handouts & 7 & 26.92 \\
\hline Classroom & Project Based & 5 & 19.23 \\
\hline Classroom & Inquiry & 4 & 15.38 \\
\hline Classroom & Demonstration & 1 & 3.85 \\
\hline Laboratory & Greenhouse & 1 & 3.85 \\
\hline Laboratory & Meats laboratory & 1 & 3.85 \\
\hline Laboratory & Other & 1 & 3.85 \\
\hline Other & Library/computer lab & 1 & 3.85 \\
\hline Other & Do not Teach & 1 & 3.85 \\
\hline Laboratory & Mechanics laboratory & 0 & 0.00 \\
\hline Laboratory & Biotechnology laboratory & 0 & 0.00 \\
\hline Laboratory & Land laboratory & 0 & 0.00 \\
\hline Laboratory & Forestry & 0 & 0.00 \\
\hline Other & Field Trip & 0 & 0.00 \\
\hline
\end{tabular}




\section{Products Derived From Grains, Legumes, and Oilseeds.}

Nine respondents (34.62\%) used classroom lecture to teach Products Derived from Grains, Legumes, and Oilseeds. Eight respondents (30.77\%) used classroom discussion. Seven respondents (26.92\%) used classroom textbooks and/or handouts. Four respondents (15.38\%) used classroom project-based learning. Four respondents $(15.38 \%)$ used classroom inquiry. One respondent (3.85\%) used classroom demonstration. One respondent (3.85\%) used classroom demonstration. One respondent $(3.85 \%)$ used greenhouse laboratory and/or supervised practice. One respondent (3.85\%) used the meats laboratory and/or supervised practice. One respondent $(3.85 \%)$ used other methods in the laboratory and/or supervised practice. One respondent $(3.85 \%)$ does not teach about products derived from grains, legumes, and oilseeds. None of the respondents used mechanics laboratory, biotechnology laboratory, land laboratory, forestry, library and/or computer lab or field trip to teach products derived from grains, legumes and oilseeds (see Table 44). 
Table 44

Methods Used to Teach Food Products and Processing CSS: Products Derived from Grains, Legumes, and Oilseeds

\begin{tabular}{|c|c|c|c|}
\hline Location & Method & $\mathrm{f}$ & $\%$ \\
\hline Classroom & Lecture & 9 & 34.62 \\
\hline Classroom & Discussion & 8 & 30.77 \\
\hline Classroom & Textbooks/handouts & 7 & 26.92 \\
\hline Classroom & Project Based & 4 & 15.38 \\
\hline Classroom & Inquiry & 4 & 15.38 \\
\hline Classroom & Demonstration & 1 & 3.85 \\
\hline Laboratory & Greenhouse & 1 & 3.85 \\
\hline Laboratory & Meats laboratory & 1 & 3.85 \\
\hline Laboratory & Other & 1 & 3.85 \\
\hline Other & Do not Teach & 1 & 3.85 \\
\hline Laboratory & Mechanics laboratory & 0 & 0.00 \\
\hline Laboratory & Biotechnology laboratory & 0 & 0.00 \\
\hline Laboratory & Land laboratory & 0 & 0.00 \\
\hline Laboratory & Forestry & 0 & 0.00 \\
\hline Other & Library/computer lab & 0 & 0.00 \\
\hline Other & Field Trip & 0 & 0.00 \\
\hline
\end{tabular}

\section{Quality and Yield Grades of Food Products.}

Ten respondents (38.46\%) used the classroom lecture to teach Quality and Yield Grades of Food Products. Seven respondents (26.92\%) used classroom discussion, and seven respondents $(26.92 \%)$ used classroom textbooks and/or handouts. Five respondents 
(19.23\%) used classroom project-based learning. Four respondents (15.38\%) used the meats laboratory and/or supervised practice. Three respondents (11.54\%) used classroom inquiry. Two respondents (7.69\%) do not teach quality and yield grades of food products. One respondent (3.85\%) used other methods in the laboratory and/or supervised practice. One respondent (3.85\%) used library and/or computer lab. None of the respondents used mechanics laboratory, greenhouse, biotechnology laboratory, land laboratory, forestry, or field trip to teach quality and yield grades of food products (see Table 45).

Table 45

Methods Used to Teach Food Products and Processing CSS: Quality and Yield Grades of Food Products

\begin{tabular}{llcc}
\hline Location & Method & $\mathrm{f}$ & $\%$ \\
\hline Classroom & Lecture & 10 & 38.46 \\
Classroom & Discussion & 7 & 26.92 \\
Classroom & Textbooks/handout & 7 & 26.92 \\
Classroom & Project Based & 5 & 19.23 \\
Classroom & Demonstration & 4 & 15.38 \\
Laboratory & Meats laboratory & 4 & 15.38 \\
Classroom & Inquiry & 3 & 11.54 \\
Other & Do not Teach & 2 & 7.69 \\
Laboratory & Other & 1 & 3.85 \\
Other & Library/computer lab & 1 & 3.85 \\
Laboratory & Mechanics laboratory & 0 & 0.00 \\
Laboratory & Greenhouse & 0 & 0.00 \\
Laboratory & Biotechnology laboratory & 0 & 0.00 \\
Laboratory & Land laboratory & 0 & 0.00 \\
Laboratory & Forestry & 0 & 0.00 \\
Other & Field Trip & 0 & 0.00 \\
\hline & & & \\
\hline
\end{tabular}




\section{History of the Animal Processing Industry.}

Ten respondents (38.46\%) used classroom lecture to teach the History of the Animal Processing Industry. Five respondents (19.23\%) do not teach the history of animal processing. Four respondents (15.38\%) used classroom discussion. Four respondents (19.23\%) used the meats laboratory and/or supervised practice. Three respondents used classroom textbooks and/or handouts. Two respondents $(7.69 \%)$ used classroom demonstration. One respondent (3.85\%) used classroom project-based learning. One respondent (3.85\%) used classroom inquiry. One respondent (3.85\%) used other methods in the laboratory and/or supervised practice. None of the respondents used mechanics laboratory, greenhouse, biotechnology laboratory, land laboratory, forestry, library and/or computer lab, or field trip to teach the history of the animal processing industry (see Table 46).

Table 46

Methods Used to Teach Food Products and Processing CSS: The History of the Animal Processing Industry

\begin{tabular}{llcc}
\hline Location & Method & $\mathrm{f}$ & $\%$ \\
\hline Classroom & Lecture & 10 & 38.46 \\
Other & Do not Teach & 5 & 19.23 \\
Classroom & Discussion & 4 & 15.38 \\
Laboratory & Meats laboratory & 4 & 15.38 \\
Classroom & Textbooks/handouts & 3 & 11.54 \\
Classroom & Demonstration & 2 & 7.69 \\
Classroom & Project Based & 1 & 3.85 \\
Classroom & Inquiry & 1 & 3.85 \\
\hline
\end{tabular}


Table 46 (continued)

Methods Used to Teach Food Products and Processing CSS: The History of the Animal Processing Industry

\begin{tabular}{llll}
\hline Location & Method & $\mathrm{f}$ & $\%$ \\
\hline Laboratory & Other & 1 & 3.85 \\
Laboratory & Mechanics laboratory & 0 & 0.00 \\
Laboratory & Greenhouse & 0 & 0.00 \\
Laboratory & Biotechnology laboratory & 0 & 0.00 \\
Laboratory & Land laboratory & 0 & 0.00 \\
Laboratory & Forestry & 0 & 0.00 \\
Other & Library/computer lab & 0 & 0.00 \\
Other & Field Trip & 0 & 0.00 \\
\hline
\end{tabular}

\section{Importance of Food Labeling to the Consumer.}

Ten respondents $(38.46 \%)$ used classroom discussion to teach the Importance of Food Labeling to the Consumer. Eight respondents (30.77\%) used classroom discussion. Four respondents (15.38\%) used classroom inquiry. Three respondents (11.54\%) used the meats laboratory and/or supervised practice. Two respondents $(7.69 \%)$ do not teach the importance of food labeling. One respondent (3.85\%) used classroom demonstration. One respondent (3.85\%) used other methods in the laboratory and/or supervised practice.

None of the respondents used project based learning, mechanics laboratory, greenhouse, biotechnology laboratory, land laboratory, forestry, library and/or computer lab or field trip to teach the importance of food labeling to the consumer (see Table 47). 
Table 47

Methods Used to Teach Food Products and Processing: The Importance of Food Labeling to the Consumer

\begin{tabular}{|c|c|c|c|}
\hline Location & Method & $\mathrm{f}$ & $\%$ \\
\hline Classroom & Discussion & 10 & 38.46 \\
\hline Classroom & Lecture & 8 & 30.77 \\
\hline Classroom & Inquiry & 4 & 15.38 \\
\hline Classroom & Textbooks/handouts & 3 & 11.54 \\
\hline Laboratory & Meats laboratory & 3 & 11.54 \\
\hline Other & Do not Teach & 2 & 7.69 \\
\hline Classroom & Demonstration & 1 & 3.85 \\
\hline Laboratory & Other & 1 & 3.85 \\
\hline Classroom & Project Based & 0 & 0.00 \\
\hline Laboratory & Mechanics laboratory & 0 & 0.00 \\
\hline Laboratory & Greenhouse & 0 & 0.00 \\
\hline Laboratory & Biotechnology laboratory & 0 & 0.00 \\
\hline Laboratory & Land laboratory & 0 & 0.00 \\
\hline Laboratory & Forestry & 0 & 0.00 \\
\hline Other & Library/computer lab & 0 & 0.00 \\
\hline Other & Field Trip & 0 & 0.00 \\
\hline
\end{tabular}

\section{Ecosystems.}

Ten respondents (38.46\%) used the classroom discussion to teach Ecosystems. Nine respondents (34.62\%) used classroom lecture. Eight respondents (30.77\%) used classroom lecture. Four respondents (15.38\%) used classroom inquiry. Three respondents 
(11.54\%) used classroom project-based learning. Two respondents (7.69\%) used library and/or computer lab. One respondent (3.85\%) used field trip. None of the respondents used demonstration, mechanics laboratory, greenhouse, meats laboratory, biotechnology laboratory, land laboratory, forestry, or other laboratory methods; and none listed do not teach for ecosystems (see Table 48).

Table 48

Methods Used to Teach Natural Resource CSS: Ecosystems

\begin{tabular}{llll}
\hline Location & Method & $\mathrm{f}$ & $\%$ \\
\hline Classroom & Discussion & 10 & 38.46 \\
Classroom & Lecture & 9 & 34.62 \\
Classroom & Textbooks/handouts & 8 & 30.77 \\
Classroom & Inquiry & 4 & 15.38 \\
Classroom & Project Based & 3 & 11.54 \\
Other & Library/computer lab & 2 & 7.69 \\
Other & Field Trip & 1 & 3.85 \\
Classroom & Demonstration & 0 & 0.00 \\
Laboratory & Mechanics laboratory & 0 & 0.00 \\
Laboratory & Greenhouse & 0 & 0.00 \\
Laboratory & Meats laboratory & 0 & 0.00 \\
Laboratory & Biotechnology laboratory & 0 & 0.00 \\
Laboratory & Land laboratory & 0 & 0.00 \\
Laboratory & Forestry & 0 & 0.00 \\
Laboratory & Other & 0 & 0.00 \\
Other & Do not Teach & 0 & 0.00 \\
\hline
\end{tabular}




\section{Identify Alternative Energy Sources.}

Eleven respondents (42.31\%) used classroom discussion to Identify Alternative Energy Sources. Eight respondents (30.77\%) used classroom lecture. Seven respondents (26.92\%) used classroom textbooks and/or handouts. Four respondents (15.38\%) used classroom project-based learning. Two respondents (7.69\%) used library and/or computer lab. Two respondents (7.69\%) do not teach identity of alternative energy sources. One respondent (3.85\%) used classroom demonstration. One respondent (3.85\%) used laboratory and/or supervised practice with the greenhouse. None of the respondents used mechanics laboratory, meats laboratory, biotechnology laboratory, land laboratory, forestry, other laboratory and/or supervised practice methods, or field trips to identify alternative energy sources (see Table 49).

Table 49

Methods Used to Natural Resources CSS: Identify Alternative Energy Sources

\begin{tabular}{llcc}
\hline Location & Method & $\mathrm{f}$ & $\%$ \\
\hline Classroom & Discussion & 11 & 42.31 \\
Classroom & Lecture & 8 & 30.77 \\
Classroom & Textbooks/handouts & 7 & 26.92 \\
Classroom & Inquiry & 5 & 19.23 \\
Classroom & Project Based & 4 & 15.38 \\
Other & Library/computer lab & 2 & 7.69 \\
Other & Do not Teach & 2 & 7.69 \\
Classroom & Demonstration & 1 & 3.85 \\
Laboratory & Greenhouse & 1 & 3.85 \\
\hline
\end{tabular}


Table 49 (continued)

Methods Used to Natural Resources CSS: Identify Alternative Energy Sources

\begin{tabular}{llll}
\hline Location & Method & $\mathrm{f}$ & $\%$ \\
\hline Laboratory & Mechanics laboratory & 0 & 0.00 \\
Laboratory & Meats laboratory & 0 & 0.00 \\
Laboratory & Biotechnology laboratory & 0 & 0.00 \\
Laboratory & Land laboratory & 0 & 0.00 \\
Laboratory & Forestry & 0 & 0.00 \\
Laboratory & Other & 0 & 0.00 \\
Other & Field Trip & 0 & $0 . .0$ \\
\hline
\end{tabular}

\section{Identify Healthy Ecosystem Characteristics.}

Ten respondents $(38.46 \%)$ used the classroom discussion to Identify Healthy Ecosystem Characteristics. Nine respondents (34.62\%) used classroom textbooks and/or handouts. Eight respondents (30.77\%) used classroom lecture. Four respondents $(15.38 \%)$ used classroom inquiry. Two respondents $(7.69 \%)$ used classroom projectbased learning. Two respondents $(7.69 \%)$ used a library and/or computer lab. One respondent (3.85\%) used land laboratory. One respondent $(3.85 \%)$ used forestry. One respondent $(3.85 \%)$ does not teach identity of healthy ecosystem characteristics. None of the respondents used demonstration, mechanics laboratory, greenhouse, meats laboratory, biotechnology laboratory, other laboratory and/or supervised practice methods or field trips to identify healthy ecosystem characteristics (see Table 50). 
Table 50

Methods Used to Teach Natural Resource CSS: Identify Healthy Ecosystem

Characteristics

\begin{tabular}{llll}
\hline Location & Method & $\mathrm{f}$ & $\%$ \\
Classroom & Discussion & 10 & 38.46 \\
Classroom & Textbooks & 9 & 34.62 \\
Classroom & Lecture & 8 & 30.77 \\
Classroom & Inquiry & 4 & 15.38 \\
Classroom & Project Based & 2 & 7.69 \\
Other & Library/computer lab & 2 & 7.69 \\
Laboratory & Land laboratory & 1 & 3.85 \\
Laboratory & Forestry & 1 & 3.85 \\
Other & Do not Teach & 1 & 3.85 \\
Classroom & Demonstration & 0 & 0.00 \\
Laboratory & Mechanics laboratory & 0 & 0.00 \\
Laboratory & Greenhouse & 0 & 0.00 \\
Laboratory & Meats laboratory & 0 & 0.00 \\
Laboratory & Field Trip & 0 & 0.00 \\
\hline Other & Maboratory & 0 & 0 \\
\hline
\end{tabular}

\section{Identify Nonrenewable Resources.}

Ten respondents (38.46\%) used classroom discussion to identify Nonrenewable Resources. Seven respondents (26.92\%) used classroom textbooks and/or handouts. Six respondents $(23.08 \%)$ used classroom lecture. Four respondents $(15.38 \%)$ used classroom 
inquiry. Three respondents (11.54) used classroom project-based learning. Three respondents (11.54\%) used library and/or computer lab. Two respondents $(7.69 \%)$ do not teach identity of nonrenewable resources. None of the respondents used demonstration, mechanics laboratory, greenhouse, meats laboratory, biotechnology laboratory, land laboratory, forestry, other laboratory methods or field trip to identify nonrenewable resources (see Table 51).

Table 51

Methods Used to Teach Natural Resource CSS: Identify Nonrenewable Resources

\begin{tabular}{llcc}
\hline Location & Method & $\mathrm{f}$ & $\%$ \\
Classroom & Discussion & 10 & 38.46 \\
Classroom & Textbooks/handouts & 7 & 26.92 \\
Classroom & Lecture & 6 & 23.08 \\
Classroom & Inquiry & 4 & 15.38 \\
Classroom & Project Based & 3 & 11.54 \\
Other & Library/computer lab & 3 & 11.54 \\
Other & Do not Teach & 2 & 7.69 \\
Classroom & Demonstration & 0 & 0.00 \\
Laboratory & Mechanics laboratory & 0 & 0.00 \\
Laboratory & Greenhouse & 0 & 0.00 \\
Laboratory & Meats laboratory & 0 & 0.00 \\
Laboratory & Biotechnology laboratory & 0 & 0.00 \\
Laboratory & Land laboratory & 0 & 0.00 \\
Laboratory & Forestry & 0 & 0.00 \\
Laboratory & Other & 0 & 0.00 \\
Other & Field trip & 0 & 0.00 \\
\hline
\end{tabular}




\section{Identify Renewable Resources.}

Eleven respondents (42.31\%) used classroom discussion to Identify Renewable Resources. Eight respondents (30.77\%) used classroom textbooks and/or handouts. Seven respondents $(26.92 \%)$ used classroom lecture. Five respondents $(19.23 \%)$ used classroom inquiry. Four respondents (15.38\%) used classroom project based learning. One respondent (3.85\%) used classroom demonstration. One respondent (3.85\%) used land laboratory and/or supervised practice. One respondent $(3.85 \%)$ used forestry laboratory and/or supervised practice. One (3.85\%) used library and/or supervised practice. One individual (3.85\%) does not teach identity of renewable resources. None of the respondents used mechanics laboratory, greenhouse, meats laboratory, biotechnology laboratory, other laboratory methods, or field trips to identify renewable resources (see Table 52).

Table 52

Methods Used to Teach Natural Resource CSS: Identify Renewable Resources

\begin{tabular}{llcc}
\hline Location & Method & $\mathrm{f}$ & $\%$ \\
\hline Classroom & Discussion & 11 & 42.31 \\
Classroom & Textbooks/handouts & 8 & 30.77 \\
Classroom & Lecture & 7 & 26.92 \\
Classroom & Inquiry & 5 & 19.23 \\
Classroom & Project Based & 4 & 15.38 \\
Classroom & Demonstration & 1 & 3.85 \\
Laboratory & Land laboratory & 1 & 3.85 \\
Laboratory & Forestry & 1 & 3.85 \\
\hline
\end{tabular}


Table 52 (continued)

Methods Used to Teach Natural Resource CSS: Identify Renewable Resources

\begin{tabular}{llll}
\hline Location & Method & $\mathrm{f}$ & $\%$ \\
\hline Other & Library/computer lab & 1 & 3.85 \\
Other & Do not Teach & 1 & 3.85 \\
Laboratory & Mechanics laboratory & 0 & 0.00 \\
Laboratory & Greenhouse & 0 & 0.00 \\
Laboratory & Meats laboratory & 0 & 0.00 \\
Laboratory & Biotechnology laboratory & 0 & 0.00 \\
Laboratory & Other & 0 & 0.00 \\
Other & Field Trip & 0 & 0.00 \\
\hline
\end{tabular}

\section{Natural Resources.}

Twelve respondents (46.15\%) used classroom lecture to teach Natural Resources. Ten respondents (38.46\%) used classroom discussion. Eight respondents (30.77\%) used classroom textbooks and/or handouts. Six respondents (23.08\%) used classroom projectbased learning. Four respondents (15.38\%) used classroom inquiry. Three respondents (11.54\%) used a library and/or computer lab. One respondent (3.85\%) used classroom demonstration. One respondent (3.85\%) used a greenhouse laboratory and/or supervised practice. One respondent (3.85\%) used a land laboratory and/or supervised practice. One respondent (3.85\%) used a forestry laboratory and/or supervised practice. None of the respondents used mechanics laboratory, meats laboratory, biotechnology laboratory, other laboratory methods, or field trip. None indicated that he or she does not teach natural resources (see table 53). 
Table 53

Methods Used to Teach Natural Resource CSS: Natural Resources

\begin{tabular}{|c|c|c|c|}
\hline Location & Method & $\mathrm{f}$ & $\%$ \\
\hline Classroom & Lecture & 12 & 46.15 \\
\hline Classroom & Discussion & 10 & 38.46 \\
\hline Classroom & Textbooks & 8 & 30.77 \\
\hline Classroom & Project Based & 6 & 23.08 \\
\hline Classroom & Inquiry & 4 & 15.38 \\
\hline Other & Library/computer lab & 3 & 11.54 \\
\hline Classroom & Demonstration & 1 & 3.85 \\
\hline Laboratory & Greenhouse & 1 & 3.85 \\
\hline Laboratory & Land laboratory & 1 & 3.85 \\
\hline Laboratory & Forestry & 1 & 3.85 \\
\hline Laboratory & Mechanics laboratory & 0 & 0.00 \\
\hline Laboratory & Meats laboratory & 0 & 0.00 \\
\hline Laboratory & Biotechnology laboratory & 0 & 0.00 \\
\hline Laboratory & Other & 0 & 0.00 \\
\hline Other & Do not Teach & 0 & 0.00 \\
\hline Other & Field Trip & 0 & 0.00 \\
\hline
\end{tabular}

\section{Nonrenewable Resources.}

Ten respondents $(38.46 \%)$ used classroom discussion to teach Nonrenewable Resources. Nine respondents (34.62\%) used classroom textbooks and/or handouts. Eight respondents $(30.77 \%)$ used classroom lecture. Five respondents $(19.23 \%)$ used classroom project-based learning. Five respondents (19.23\%) used classroom inquiry. Three 
respondents (11.54\%) used a library and/or computer lab. One respondent $(3.85 \%)$ used classroom demonstration. One respondent (3.85\%) used a biotechnology laboratory and/or supervised practice. One respondent (3.85\%) does not teach the concept. None of the respondents used mechanics laboratory, greenhouse, meats laboratory, land laboratory, forestry, other laboratory methods or field trips (see Table 54).

Table 54

Methods Used to Teach Natural Resource CSS: Nonrenewable Resources

\begin{tabular}{|c|c|c|c|}
\hline Location & Method & $\mathrm{f}$ & $\%$ \\
\hline Classroom & Discussion & 10 & 38.46 \\
\hline Classroom & Textbooks/handouts & 9 & 34.62 \\
\hline Classroom & Lecture & 8 & 30.77 \\
\hline Classroom & Project based & 5 & 19.23 \\
\hline Classroom & Inquiry & 5 & 19.23 \\
\hline Other & Library/computer lab & 3 & 11.54 \\
\hline Classroom & Demonstration & 1 & 3.85 \\
\hline Laboratory & Biotechnology laboratory & 1 & 3.85 \\
\hline Other & Do not Teach & 1 & 3.85 \\
\hline Laboratory & Mechanics laboratory & 0 & 0.00 \\
\hline Laboratory & Greenhouse & 0 & 0.00 \\
\hline Laboratory & Meats laboratory & 0 & 0.00 \\
\hline Laboratory & Land laboratory & 0 & 0.00 \\
\hline Laboratory & Forestry & 0 & 0.00 \\
\hline Laboratory & Other & 0 & 0.00 \\
\hline Other & Field Trip & 0 & 0.00 \\
\hline
\end{tabular}




\section{Renewable Resources.}

Ten respondents (38.46\%) used classroom discussion to teach Renewable Resources. Ten respondents (38.46\%) used classroom textbooks and/or handouts. Eight respondents (30.77\%) used classroom lecture. Four respondents (15.38\%) used classroom project-based learning. Four respondents (15.38\%) used classroom inquiry. One respondent (3.85\%) used a greenhouse laboratory and/or supervised practice in the greenhouse. One respondent (3.85\%) used a biotechnology laboratory and/or supervised practice. One respondent (3.85\%) used the forestry laboratory and/or supervised practice. One respondent (3.85\%) used the library and/or computer lab. One respondent $(3.85 \%)$ does not teach renewable resources. None of the respondents used demonstration, mechanics laboratory, meats laboratory, land laboratory, other laboratory methods, or field trip (see Table 55).

Table 55

Methods Used to Teach Natural Resource CSS: Renewable Resources

\begin{tabular}{llcc}
\hline Location & Method & $\mathrm{f}$ & $\%$ \\
\hline Classroom & Discussion & 10 & 38.46 \\
Classroom & Textbooks/handouts & 10 & 38.46 \\
Classroom & Lecture & 8 & 30.77 \\
Classroom & Project Based & 4 & 15.38 \\
Classroom & Inquiry & 4 & 15.38 \\
Laboratory & Greenhouse & 1 & 3.85 \\
Laboratory & Biotechnology laboratory & 1 & 3.85 \\
Laboratory & Forestry & 1 & 3.85 \\
Other & Library/computer lab & 1 & 3.85 \\
\hline
\end{tabular}


Table 55 (continued)

Methods Used to Teach Natural Resource CSS: Renewable Resources

\begin{tabular}{llll}
\hline Location & Method & $\mathrm{f}$ & $\%$ \\
\hline Other & Do not Teach & 1 & 3.85 \\
Classroom & Demonstration & 0 & 0.00 \\
Laboratory & Mechanics laboratory & 0 & 0.00 \\
Laboratory & Meats laboratory & 0 & 0.00 \\
Laboratory & Land laboratory & 0 & 0.00 \\
Laboratory & Other & 0 & 0.00 \\
Other & Field trip & 0 & 0.00 \\
\hline
\end{tabular}

\section{Basic Plant Nutrition.}

Ten respondents (38.46\%) used classroom lecture to teach Basic Plant Nutrition. Nine respondents $(34.62 \%)$ used classroom textbooks and/or handouts. Eight respondents (30.77\%) used classroom project-based learning. Eight respondents $(30.77 \%)$ used the laboratory and/or supervised practice in the greenhouse. Seven respondents $(26.92 \%)$ used classroom discussion. Four respondents (15.38\%) used classroom inquiry. Three respondents (11.54\%) used classroom demonstration. Two respondents $(7.69 \%)$ used a biotechnology laboratory and/or supervised practice. None of the respondents used mechanics laboratory, meats laboratory, land laboratory, forestry, other laboratory methods, library and/or computer lab, or field trip. None indicated that he/she does not teach basic plant nutrition (see Table 56). 
Table 56

Methods Used to Teach Plant Systems CSS: Basic Plant Nutrition

\begin{tabular}{|c|c|c|c|}
\hline Location & Method & $\mathrm{f}$ & $\%$ \\
\hline Classroom & Lecture & 10 & 38.46 \\
\hline Classroom & Textbooks/handouts & 9 & 34.62 \\
\hline Classroom & Project Based & 8 & 30.77 \\
\hline Laboratory & Greenhouse & 8 & 30.77 \\
\hline Classroom & Discussion & 7 & 26.92 \\
\hline Classroom & Inquiry & 4 & 15.38 \\
\hline Classroom & Demonstration & 3 & 11.54 \\
\hline Laboratory & Biotechnology laboratory & 2 & 7.69 \\
\hline Laboratory & Mechanics laboratory & 0 & 0.00 \\
\hline Laboratory & Meats laboratory & 0 & 0.00 \\
\hline Laboratory & Land laboratory & 0 & 0.00 \\
\hline Laboratory & Forestry & 0 & 0.00 \\
\hline Laboratory & Other & 0 & 0.00 \\
\hline Other & Library/computer lab & 0 & 0.00 \\
\hline Other & Field Trip & 0 & 0.00 \\
\hline Other & Do not Teach & 0 & 0.00 \\
\hline
\end{tabular}

Basic Soil Science.

Eleven respondents $(42.31 \%)$ used classroom textbooks and/or handouts to teach Basic Soil Science. Nine respondents (34.62\%) used classroom project based learning. Nine respondents (34.62\%) used classroom lecture. Six respondents $(23.08 \%)$ used classroom discussion. Six respondents (23.08\%) used classroom demonstration. Five 
respondents (19.23\%) used greenhouse laboratory and/or supervised practice. Four respondents $(15.38 \%)$ used land laboratory and/or supervised practice. Three respondents (11.54\%) used classroom inquiry. Two respondents (7.69\%) used a biotechnology laboratory and/or supervised practice. None of the respondents used mechanics laboratory, meats laboratory, forestry, other laboratory methods, field trip, or library and/or computer lab to teach basic soil science; and none indicated that he/she does not teach basic soil science (see Table 57).

Table 57

Methods Used to Teach Plant Systems CSS: Basic Soil Science

\begin{tabular}{llcc}
\hline Location & Method & $\mathrm{f}$ & $\%$ \\
\hline Classroom & Textbooks/handouts & 11 & 42.31 \\
Classroom & Project Based & 9 & 34.62 \\
Classroom & Lecture & 9 & 34.62 \\
Classroom & Discussion & 6 & 23.08 \\
Classroom & Demonstration & 6 & 23.08 \\
Laboratory & Greenhouse & 5 & 19.23 \\
Laboratory & Land laboratory & 4 & 15.38 \\
Classroom & Inquiry & 3 & 11.54 \\
Laboratory & Biotechnology laboratory & 2 & 7.69 \\
Laboratory & Mechanics laboratory & 0 & 0.00 \\
Laboratory & Meats laboratory & 0 & 0.00 \\
Laboratory & Forestry & 0 & 0.00 \\
Laboratory & Other & 0 & 0.00 \\
Other & Field Trip & 0 & 0.00 \\
Other & Do not Teach & 0 & 0.00 \\
Other & Library/computer lab & 0.00 \\
\hline
\end{tabular}




\section{Conduct Soil Sampling and Testing.}

Ten respondents (38.46\%) used classroom project-based learning to Conduct Soil Sampling and Testing. Seven respondents (26.92\%) used greenhouse laboratory and/or supervised practice. Six respondents (23.08\%) used classroom textbooks and/or handouts. Five respondents (19.23\%) used classroom discussion. Five respondents (19.23\%) used classroom lecture. Four respondents (15.38\%) used classroom demonstration. Four respondents (15.38\%) used land laboratory and/or supervised practice. Three respondents (11.54\%) used classroom inquiry. Two respondents (7.69\%) used field trip. One respondent (3.85\%) used a biotechnology laboratory and/or supervised practice. None of the respondents used mechanics laboratory, meats laboratory, forestry, other laboratory methods, or library and/or computer lab; and none indicated that he/she does not teach conducting soil sampling and testing (see Table 58).

Table 58

Methods Used to Teach Plant Systems CSS: Conduct Soil Sampling and Testing

\begin{tabular}{llcc}
\hline Location & Method & $\mathrm{f}$ & $\%$ \\
\hline Classroom & Project Based & 10 & 38.46 \\
Laboratory & Greenhouse & 7 & 26.92 \\
Classroom & Textbooks/handouts & 6 & 23.08 \\
Classroom & Discussion & 5 & 19.23 \\
Classroom & Lecture & 5 & 19.23 \\
Classroom & Demonstration & 4 & 15.38 \\
Laboratory & Land laboratory & 4 & 15.38 \\
Classroom & Inquiry & 3 & 11.54 \\
Other & Field Trip & 2 & 7.69 \\
\hline
\end{tabular}


Table 58 (continued)

Methods Used to Teach Plant Systems CSS: Conduct Soil Sampling and Testing

\begin{tabular}{llll}
\hline Location & Method & $\mathrm{f}$ & $\%$ \\
\hline Laboratory & Biotechnology laboratory & 1 & 3.85 \\
Laboratory & Mechanics laboratory & 0 & 0.00 \\
Laboratory & Meats laboratory & 0 & 0.00 \\
Laboratory & Forestry & 0 & 0.00 \\
Laboratory & Other & 0 & 0.00 \\
Other & Library/computer lab & 0 & 0.00 \\
Other & Do not Teach & 0 & 0.00 \\
\hline
\end{tabular}

Diagram a Typical Plant Cell and Identify Cell Organelles and Their

Functions.

Nine respondents (34.62\%) used classroom textbooks and/or handouts to Diagram a Typical Plant Cell and Identify Cell Organelles and Their Functions. Eight respondents $(30.77 \%)$ used classroom lecture. Seven respondents $(26.92 \%)$ used classroom discussion. Seven respondents (26.92\%) used greenhouse laboratory and/or supervised practice. Four respondents (15.38\%) used classroom project-based learning. Three respondents (11.54\%) used classroom inquiry. One respondent (3.85\%) used a biotechnology laboratory and/or supervised practice. One respondent (3.85\%) used a library and/or computer lab. None of the respondents used demonstration, mechanics laboratory, meats laboratory, land laboratory, forestry, other laboratory methods, or field trip; and none indicated that he/she does not teach students to diagram typical plant cells and to identify cell organelles and their functions (see Table 59). 
Table 59

Methods Used to Teach Plant Systems CSS: Diagram a Typical Plant Cell and Identify Cell Organelles and their Functions

\begin{tabular}{|c|c|c|c|}
\hline Location & Method & $\mathrm{f}$ & $\%$ \\
\hline Classroom & Textbooks/handouts & 9 & 34.62 \\
\hline Classroom & Lecture & 8 & 30.77 \\
\hline Classroom & Discussion & 7 & 26.92 \\
\hline Laboratory & Greenhouse & 7 & 26.92 \\
\hline Classroom & Project Based & 4 & 15.38 \\
\hline Classroom & Inquiry & 3 & 11.54 \\
\hline Laboratory & Biotechnology laboratory & 1 & 3.85 \\
\hline Other & Library/computer lab & 1 & 3.85 \\
\hline Classroom & Demonstration & 0 & 0.00 \\
\hline Laboratory & Mechanics laboratory & 0 & 0.00 \\
\hline Laboratory & Meats laboratory & 0 & 0.00 \\
\hline Laboratory & Land laboratory & 0 & 0.00 \\
\hline Laboratory & Forestry & 0 & 0.00 \\
\hline Laboratory & Other & 0 & 0.00 \\
\hline Other & Field Trip & 0 & 0.00 \\
\hline Other & Do not Teach & 0 & 0.00 \\
\hline
\end{tabular}

\section{Functions of Plant Parts.}

Ten respondents $(38.46 \%)$ used classroom textbooks and/or handouts to teach the Functions of Plant Parts. Nine respondents (34.62\%) used classroom lecture. Nine respondents (34.62\%) used greenhouse laboratory and/or supervised practice. Eight 
respondents (30.77\%) used classroom discussion. Six respondents $(23.08 \%)$ used classroom project-based learning. Three respondents (11.54\%) used classroom demonstration. Two respondents (7.69\%) used classroom inquiry. One respondent (3.85\%) used a biotechnology laboratory and/or supervised practice. One respondent (3.85\%) used a land laboratory and/or supervised practice. One respondent $(3.85 \%)$ used a forestry laboratory and/or supervised practice. None of the respondents used mechanics laboratory, meats laboratory, other laboratory methods, library and/or computer lab, or field trip to teach the functions of plant parts; and none indicated that he/she does not teach functions of plant parts (see Table 60).

Table 60

Methods Used to Teach Plant Systems CSS: Functions of Plant Parts

\begin{tabular}{llcc}
\hline Location & Method & $\mathrm{f}$ & $\%$ \\
\hline Classroom & Textbooks/handouts & 10 & 38.46 \\
Classroom & Lecture & 9 & 34.62 \\
Laboratory & Greenhouse & 9 & 34.62 \\
Classroom & Discussion & 8 & 30.77 \\
Classroom & Project Based & 6 & 23.08 \\
Classroom & Demonstration & 3 & 11.54 \\
Classroom & Inquiry & 2 & 7.69 \\
Laboratory & Biotechnology laboratory & 1 & 3.85 \\
Laboratory & Land laboratory & 1 & 3.85 \\
Laboratory & Forestry & 1 & 3.85 \\
Laboratory & Mechanics laboratory & 0 & 0.00 \\
Laboratory & Meats laboratory & 0 & 0.00 \\
Laboratory & Other & 0 & 0.00 \\
Other & Library/computer lab & 0 & 0.00 \\
Other & Field Trip & 0 & 0.00 \\
\hline
\end{tabular}




\section{Identify Agriculturally Important Plants by Common Names.}

Nine respondents $(34.62 \%)$ used classroom project-based learning to Identify Agriculturally Important Plants by Common Names. Eight respondents (30.77\%) used classroom discussion. Eight respondents (30.77\%) used classroom lecture. Eight respondents (30.77\%) used classroom textbooks and/or handouts. Seven respondents $(26.92 \%)$ used a greenhouse laboratory and/or supervised practice. Three respondents (11.54\%) used classroom inquiry. Three respondents (11.54\%) used a library and/or computer lab. Two respondents (7.69\%) used a land laboratory and/or supervised practice. One respondent $(3.85 \%)$ used a classroom demonstration. One respondent (3.85\%) used s a biotechnology laboratory and/or supervised practice. One respondent $(3.85 \%)$ used a forestry laboratory and/or supervised practice. One respondent $(3.85 \%)$ used field trip. One respondent (3.85\%) does not teach students to identify agriculturally important plants by common names. None of the respondents used mechanics laboratory, meats laboratory or other laboratory and/or supervised practice to identify agriculturally important plants by common names (see Table 61). 
Table 61

Methods Used to Teach Plant Systems CSS: Identify Agriculturally Important Plants by Common Names

\begin{tabular}{|c|c|c|c|}
\hline Location & Method & $\mathrm{f}$ & $\%$ \\
\hline Classroom & Project Based & 9 & 34.62 \\
\hline Classroom & Discussion & 8 & 30.77 \\
\hline Classroom & Lecture & 8 & 30.77 \\
\hline Classroom & Textbooks/handouts & 8 & 30.77 \\
\hline Laboratory & Greenhouse & 7 & 26.92 \\
\hline Classroom & Inquiry & 3 & 11.54 \\
\hline Other & Library/computer lab & 3 & 11.54 \\
\hline Laboratory & Land laboratory & 2 & 7.69 \\
\hline Classroom & Demonstration & 1 & 3.85 \\
\hline Laboratory & Biotechnology laboratory & 1 & 3.85 \\
\hline Laboratory & Forestry & 1 & 3.85 \\
\hline Other & Field Trip & 1 & 3.85 \\
\hline Other & Do not Teach & 1 & 3.85 \\
\hline Laboratory & Mechanics laboratory & 0 & 0.00 \\
\hline Laboratory & Meats laboratory & 0 & 0.00 \\
\hline Laboratory & Other & 0 & 0.00 \\
\hline
\end{tabular}

\section{Identify The Components and Functions of Plant Roots.}

Ten respondents $(38.46 \%)$ used classroom textbooks and/or handouts to Identify The Components and Functions of Plant Roots. Nine respondents (34.62\%) used classroom lecture. Eight respondents (30.77\%) used classroom discussion. Eight 
respondents (30.77\%) used greenhouse laboratory and/or supervised practice. Six respondents $(23.08 \%)$ used classroom project based learning. Three respondents (11.54\%) used classroom inquiry. Two respondents (7.69\%) used biotechnology laboratory and/or supervised practice. None of the respondents used demonstration, mechanics laboratory, meats laboratory, land laboratory, forestry, other laboratory methods, library and/or computer lab, or field trip; and none marked do not teach to identify the components and functions of plant roots (see Table 62).

Table 62

Methods Used to Teach Plant System CSS: Identify the Components and Functions of Plant Roots

\begin{tabular}{llcc}
\hline Location & Method & $\mathrm{f}$ & $\%$ \\
\hline Classroom & Textbooks/handouts & 10 & 38.46 \\
Classroom & Lecture & 9 & 34.62 \\
Classroom & Discussion & 8 & 30.77 \\
Laboratory & Greenhouse & 8 & 30.77 \\
Classroom & Project Based & 6 & 23.08 \\
Classroom & Inquiry & 3 & 11.54 \\
Laboratory & Biotechnology laboratory & 2 & 7.69 \\
Classroom & Demonstration & 0 & 0.00 \\
Laboratory & Mechanics laboratory & 0 & 0.00 \\
Laboratory & Meats laboratory & 0 & 0.00 \\
Laboratory & Land laboratory & 0 & 0.00 \\
Laboratory & Forestry & 0 & 0.00 \\
Laboratory & Other & 0 & 0.00 \\
Other & Library/computer lab & 0 & 0.00 \\
Other & Field Trip & 0 & 0.00 \\
Other & Do not Teach & 0.00 \\
\hline
\end{tabular}




\section{Components and Functions of Plant Flowers.}

Ten respondents (38.46\%) used classroom textbooks and/or handouts to identify the Components and Functions of Plant Flowers. Eight respondents (30.77\%) used classroom discussion. Eight respondents (30.77\%) used classroom lecture. Eight (30.77\%) used a greenhouse laboratory and/or supervised practice. Five respondents (19.23\%) used classroom project-based learning. Two respondents (7.69\%) used classroom inquiry. Two respondents (7.69\%) used a biotechnology laboratory and/or supervised practice. One respondent (3.85\%) used classroom demonstration. One respondent (3.85\%) used a forestry laboratory and/or supervised practice. None of the respondents used mechanics laboratory, meats laboratory, land laboratory, other laboratory methods, library and/or computer lab, or field trip; nor does any indicate that he/she does not teach students to identify the components and functions of plant flowers (see Table 63).

Table 63

Methods Used to Teach Plant Systems CSS: Identify the Components and the Functions of Plant Flowers

\begin{tabular}{llcc}
\hline Location & Method & $\mathrm{f}$ & $\%$ \\
\hline Classroom & Textbooks/handouts & 10 & 38.46 \\
Classroom & Discussion & 8 & 30.77 \\
Classroom & Lecture & 8 & 30.77 \\
Laboratory & Greenhouse & 8 & 30.77 \\
Classroom & Project Based & 5 & 19.23 \\
Classroom & Inquiry & 2 & 7.69 \\
\hline
\end{tabular}


Table 63 (continued)

Methods Used to Teach Plant Systems CSS: Identify the Components and the Functions of Plant Flowers

\begin{tabular}{llll}
\hline Location & Method & $\mathrm{f}$ & $\%$ \\
\hline Laboratory & Biotechnology laboratory & 2 & 7.69 \\
Classroom & Demonstration & 1 & 3.85 \\
Laboratory & Forestry & 1 & 3.85 \\
Laboratory & Mechanics laboratory & 0 & 0.00 \\
Laboratory & Meats laboratory & 0 & 0.00 \\
Laboratory & Land laboratory & 0 & 0.00 \\
Laboratory & Other & 0 & 0.00 \\
Other & Library/computer lab & 0 & 0.00 \\
Other & Field Trip & 0 & 0.00 \\
Other & Do not Teach & 0 & 0.00 \\
\hline
\end{tabular}

\section{Components and Functions of Plant Leaves.}

Ten respondents $(38.46 \%)$ used classroom textbooks and/or handouts to identify the Components and Functions of Plant Leaves. Eight respondents (30.77\%) used classroom discussion. Eight respondents (30.77\%) used greenhouse laboratory and/or supervised practice. Seven respondents $(26.92 \%)$ used classroom lecture. Six respondents (23.08\%) used classroom project-based learning. Three respondents (11.54\%) used classroom inquiry. Two respondents (7.69\%) used a biotechnology laboratory and/or supervised practice. One respondent (3.85\%) used a forestry laboratory and/or supervised practice. None of the respondents used demonstration, mechanics laboratory, meats 
laboratory, land laboratory, other laboratory methods, library and/or computer lab, or field trip; and all teach students to identify the components and functions of plant leaves (see Table 64).

Table 64

Methods Used to Teach Plant System CSS: Identify the Components and the Functions of Plant Leaves

\begin{tabular}{llcl}
\hline Location & Method & $\mathrm{f}$ & $\%$ \\
\hline Classroom & Textbooks/handouts & 10 & 38.46 \\
Classroom & Discussion & 8 & 30.77 \\
Laboratory & Greenhouse & 8 & 30.77 \\
Classroom & Lecture & 7 & 26.92 \\
Classroom & Project Based & 6 & 23.08 \\
Classroom & Inquiry & 3 & 11.54 \\
Laboratory & Biotechnology laboratory & 2 & 7.69 \\
Laboratory & Forestry & 1 & 3.85 \\
Classroom & Demonstration & 0 & 0.00 \\
Laboratory & Mechanics laboratory & 0 & 0.00 \\
Laboratory & Meats laboratory & 0 & 0.00 \\
Laboratory & Land laboratory & 0 & 0.00 \\
Laboratory & Other & 0 & 0.00 \\
Other & Library/computer lab & 0 & 0.00 \\
Other & Field Trip & 0 & 0.00 \\
Other & Do not Teach & 0 & 0.00 \\
\hline
\end{tabular}




\section{Identify the Components and Functions of Plant Stems.}

Ten respondents $(38.46 \%)$ used classroom textbooks and/or handouts to Identify the Components and Functions of Plant Stems. Eight respondents (30.77\%) used classroom discussion. Eight respondents (30.77\%) used classroom lecture. Seven respondents (26.92\%) used the greenhouse laboratory and/or supervised practice. Six respondents $(23.08 \%)$ used classroom project-based learning. Two respondents $(7.69 \%)$ used classroom inquiry. Two respondents (7.69\%) used a biotechnology laboratory and/or supervised practice. None of the respondents used demonstration, mechanics laboratory, meats laboratory, land laboratory, forestry, other laboratory methods, library and/or computer lab, or field trip. Every respondent teaches students to identify the components and functions of plant stems (see Table 65).

Table 65

Methods Used to Teach Plant System CSS: Identify the Components and the Functions of Plant Stems

\begin{tabular}{llll}
\hline Location & Method & $\mathrm{f}$ & $\%$ \\
\hline Classroom & Textbooks/handouts & 10 & 38.46 \\
Classroom & Discussion & 8 & 30.77 \\
Classroom & Lecture & 8 & 30.77 \\
Laboratory & Greenhouse & 7 & 26.92 \\
Classroom & Project Based & 6 & 23.08 \\
Classroom & Inquiry & 2 & 7.69 \\
Laboratory & Biotechnology laboratory & 2 & 7.69 \\
Classroom & Demonstration & 0 & 0.00 \\
Laboratory & Mechanics laboratory & 0 & 0.00 \\
\hline
\end{tabular}


Table 65 (continued)

Methods Used to Teach Plant System CSS: Identify the Components and the Functions of Plant Stems

\begin{tabular}{llll}
\hline Location & Method & $\mathrm{f}$ & $\%$ \\
\hline Laboratory & Meats laboratory & 0 & 0.00 \\
Laboratory & Land laboratory & 0 & 0.00 \\
Laboratory & Forestry & 0 & 0.00 \\
Laboratory & Other & 0 & 0.00 \\
Other & Library/computer lab & 0 & 0.00 \\
Other & Field Trip & 0 & 0.00 \\
Other & Do not Teach & 0 & 0.00 \\
\hline
\end{tabular}

\section{Interpret Soil Results to Determine Fertilizer Application Needs.}

Nine respondents $(34.62 \%)$ used the greenhouse laboratory and/or supervised practice to Interpret Soil Results to Determine Fertilizer Application Needs. Seven respondents $(26.92 \%)$ used classroom project based learning. Seven respondents (26.92\%) used classroom discussion. Seven respondents (26.92\%) used classroom lecture. Six respondents (23.08\%) used classroom textbooks and/or handouts. Four respondents (15.38\%) used classroom inquiry. Four respondents (15.38\%) used classroom demonstration. One respondent (3.85\%) used biotechnology laboratory and/or supervised practice. One respondent (3.85\%) used a land laboratory and/or supervised practice. One respondent (3.85\%) used a library and/or computer lab. One respondent $(3.85 \%)$ used field trips. One respondent (3.85\%) does not teach interpretation and 
application. None of the respondents used mechanics laboratory, meats laboratory, forestry, or other laboratory methods (see Table 66).

Table 66

Methods Used to Teach Plant System CSS: Interpret Soil Results to Determine Fertilizer Application Needs

\begin{tabular}{|c|c|c|c|}
\hline Location & Method & $\mathrm{f}$ & $\%$ \\
\hline Laboratory & Greenhouse & 9 & 34.62 \\
\hline Classroom & Project Based & 7 & 26.92 \\
\hline Classroom & Discussion & 7 & 26.92 \\
\hline Classroom & Lecture & 7 & 26.92 \\
\hline Classroom & Textbooks/handouts & 6 & 23.08 \\
\hline Classroom & Inquiry & 4 & 15.38 \\
\hline Classroom & Demonstration & 4 & 15.38 \\
\hline Laboratory & Biotechnology laboratory & 1 & 3.85 \\
\hline Laboratory & Land laboratory & 1 & 3.85 \\
\hline Other & Library/computer lab & 1 & 3.85 \\
\hline Other & Field Trip & 1 & 3.85 \\
\hline Other & Do not Teach & 1 & 3.85 \\
\hline Laboratory & Mechanics laboratory & 0 & 0.00 \\
\hline Laboratory & Meats laboratory & 0 & 0.00 \\
\hline Laboratory & Forestry & 0 & 0.00 \\
\hline Laboratory & Other & 0 & 0.00 \\
\hline
\end{tabular}




\section{Parts of a Plant.}

Ten respondents $(38.46 \%)$ used classroom textbooks and/or handouts to teach Parts of a Plant. Nine respondents (34.62\%) used the greenhouse laboratory and/or supervised practice. Seven respondents $(26.92 \%)$ used classroom project-based learning. Five respondents (19.23\%) used classroom discussion. Five respondents (19.23\%) used classroom demonstration. Three respondents (11.54\%) used classroom inquiry. One respondent $(3.85 \%)$ used a biotechnology laboratory and/or supervised practice. One respondent (38.5\%) used a forestry laboratory and/or supervised practice. None of the respondents used mechanics laboratory, meats laboratory, land laboratory, other laboratory methods, library and/or computer lab, or field trip. Everyone teaches students to identify the parts of a plant (see Table 67).

Table 67

Methods Used to Teach Plant System CSS: Parts of a Plant

\begin{tabular}{llll}
\hline Location & Method & $\mathrm{f}$ & $\%$ \\
\hline Classroom & Textbooks/handouts & 10 & 38.46 \\
Laboratory & Greenhouse & 9 & 34.62 \\
Classroom & Lecture & 8 & 30.77 \\
Classroom & Project Based & 7 & 26.92 \\
Classroom & Discussion & 5 & 19.23 \\
Classroom & Demonstration & 5 & 19.23 \\
Classroom & Inquiry & 3 & 11.54 \\
Laboratory & Biotechnology laboratory & 1 & 3.85 \\
Laboratory & Forestry & 1 & 3.85 \\
Laboratory & Mechanics laboratory & 0 & 0.00 \\
\hline
\end{tabular}


Table 67 (continued)

Methods Used to Teach Plant System CSS: Parts of a Plant

\begin{tabular}{llll}
\hline Location & Method & $\mathrm{f}$ & $\%$ \\
\hline Laboratory & Meats laboratory & 0 & 0.00 \\
Laboratory & Land laboratory & 0 & 0.00 \\
Laboratory & Other & 0 & 0.00 \\
Other & Library/computer lab & 0 & 0.00 \\
Other & Field Trip & 0 & 0.00 \\
Other & Do not Teach & 0 & 0.00 \\
\hline
\end{tabular}

Plant Physiology - Photosynthesis, Reproduction, Respiration, and

\section{Transpiration.}

Eleven respondents (42.31\%) used the classroom lecture to teach Plant Physiology - Photosynthesis, Reproduction, Respiration, and Transpiration. Ten respondents (38.46\%) used classroom textbooks and/or handouts. Seven respondents (26.92\%) used classroom discussion. Six respondents $(23.08 \%)$ used the greenhouse laboratory and/or supervised practice. Five respondents (19.23\%) used classroom projectbased learning. Four respondents (15.38\%) used classroom inquiry. Two respondents (7.69\%) used a biotechnology laboratory and/or supervised practice. One respondent (3.85\%) used classroom demonstration. None of the respondents used mechanics laboratory, meats laboratory, land laboratory, forestry, other laboratory methods, library and/or computer lab, or field trip; and all teach plant physiology (see Table 68). 
Table 68

Methods Used to Teach Plant System CSS: Plant Physiology - Photosynthesis, Reproduction, Respiration, and Transpiration

\begin{tabular}{|c|c|c|c|}
\hline Location & Method & $\mathrm{f}$ & $\%$ \\
\hline Classroom & Lecture & 11 & 42.31 \\
\hline Classroom & Textbooks/handouts & 10 & 38.46 \\
\hline Classroom & Discussion & 7 & 26.92 \\
\hline Laboratory & Greenhouse & 6 & 23.08 \\
\hline Classroom & Project Based & 5 & 19.23 \\
\hline Classroom & Inquiry & 4 & 15.38 \\
\hline Laboratory & Biotechnology laboratory & 2 & 7.69 \\
\hline Classroom & Demonstration & 1 & 3.85 \\
\hline Laboratory & Mechanics laboratory & 0 & 0.0 \\
\hline Laboratory & Meats laboratory & 0 & 0.00 \\
\hline Laboratory & Land laboratory & 0 & 0.00 \\
\hline Laboratory & Forestry & 0 & 0.00 \\
\hline Laboratory & Other & 0 & 0.00 \\
\hline Other & Library/computer lab & 0 & 0.00 \\
\hline Other & Field Trip & 0 & 0.00 \\
\hline Other & Do not Teach & 0 & 0.00 \\
\hline
\end{tabular}

\section{Teach Adding, Subtracting, Multiplying, and Dividing Decimals.}

Six respondents $(23.08 \%)$ used classroom textbooks and/or handouts to Teach Adding, Subtracting, Multiplying, and Dividing Decimals, with and without a calculator. Six respondents $(23.08 \%)$ used a mechanics laboratory and/or supervised practice. Five 
respondents (19.23\%) used classroom discussion. Five respondents (19.23\%) used classroom demonstration. Five respondents (19.23\%) used classroom lecture. Three respondents (11.54\%) used classroom project-based learning. Three respondents (11.54\%) used classroom inquiry. Three respondents $(11.54 \%)$ used the greenhouse laboratory and/or supervised practice. Three respondents (11.54\%) do not teach math skills listed in table 69 . One respondent $(3.85 \%)$ used the meats laboratory and/or supervised practice. None of the respondents used biotechnology laboratory, land laboratory, forestry, other laboratory methods, library and/or computer lab or field trip to teach adding, subtracting, multiplying, and dividing decimals, with and without a calculator (see Table 69).

Table 69

Methods Used to Teach Power, Structural, and Technical CSS: Add, Subtract, Multiply, and Divide Decimals, with and without a Calculator

\begin{tabular}{llll}
\hline Location & Method & $\mathrm{f}$ & $\%$ \\
\hline Classroom & Textbooks/handouts & 6 & 23.08 \\
Laboratory & Mechanics laboratory & 6 & 23.08 \\
Classroom & Discussion & 5 & 19.23 \\
Classroom & Demonstration & 5 & 19.23 \\
Classroom & Lecture & 5 & 19.23 \\
Classroom & Project Based & 3 & 11.54 \\
Classroom & Inquiry & 3 & 11.54 \\
Laboratory & Greenhouse & 3 & 11.54 \\
Other & Do not Teach & 3 & 11.54 \\
Laboratory & Meats laboratory & 1 & 3.85 \\
\hline
\end{tabular}


Table 69 (continued)

Methods Used to Teach Power, Structural, and Technical CSS: Add, Subtract, Multiply, and Divide Decimals, with and without a Calculator

\begin{tabular}{llll}
\hline Location & Method & $\mathrm{f}$ & $\%$ \\
\hline Laboratory & Biotechnology laboratory & 0 & 0.00 \\
Laboratory & Land laboratory & 0 & 0.00 \\
Laboratory & Forestry & 0 & 0.00 \\
Laboratory & Other & 0 & 0.00 \\
Other & Library/computer lab & 0 & 0.00 \\
Other & Field Trip & 0 & 0.00 \\
\hline
\end{tabular}

\section{Adding, Subtracting, Multiplying, and Dividing Fractions.}

Six respondents $(23.08 \%)$ used classroom textbooks and/or handouts to teach Adding, Subtracting, Multiplying, and Dividing Fractions. Six respondents (23.08\%) used mechanics laboratory and/or supervised practice. Five respondents (19.23\%) used classroom discussion. Five respondents (19.23\%) used classroom lecture. Four respondents (15.38\%) used classroom demonstration. Three respondents $(11.54 \%)$ used classroom project based learning. Three respondents (11.54\%) used classroom inquiry. Three respondents (11.54\%) used the greenhouse laboratory and/or supervised practice. Three respondents $(11.54 \%)$ do not teach these math skills. One respondent $(3.85 \%)$ used the meats laboratory and/or supervised practice. None of the respondents used biotechnology laboratory, land laboratory, forestry, other laboratory methods, library and/or computer lab or field trip to teach adding, subtracting, multiplying, and dividing fractions (see Table 70). 
Table 70

Methods Used to Teach Power, Structural, and Technical CSS: Add, Subtract, Multiply, and Divide Fractions

\begin{tabular}{|c|c|c|c|}
\hline Location & Method & $\mathrm{f}$ & $\%$ \\
\hline Classroom & Textbooks/handouts & 6 & 23.08 \\
\hline Laboratory & Mechanics laboratory & 6 & 23.08 \\
\hline Classroom & Discussion & 5 & 19.23 \\
\hline Classroom & Lecture & 5 & 19.23 \\
\hline Classroom & Demonstration & 4 & 15.38 \\
\hline Classroom & Project Based & 3 & 11.54 \\
\hline Classroom & Inquiry & 3 & 11.54 \\
\hline Laboratory & Greenhouse & 3 & 11.54 \\
\hline Other & Do not Teach & 3 & 11.54 \\
\hline Laboratory & Meats laboratory & 1 & 3.85 \\
\hline Laboratory & Biotechnology laboratory & 0 & 0.00 \\
\hline Laboratory & Land laboratory & 0 & 0.00 \\
\hline Laboratory & Forestry & 0 & 0.00 \\
\hline Laboratory & Other & 0 & 0.00 \\
\hline Other & Library/computer lab & 0 & 0.00 \\
\hline Other & Field Trip & 0 & 0.00 \\
\hline
\end{tabular}

Adding, Subtracting, Multiplying, and Dividing Whole Numbers.

Eight respondents $(30.77 \%)$ used classroom textbooks and/or handouts to teach Adding, Subtracting, Multiplying, and Dividing Whole Numbers, with and without a calculator. Six respondents (23.08\%) used classroom lecture. Six respondents $(23.08 \%)$ 
used the mechanics laboratory and/or supervised practice. Five respondents $(19.23 \%)$ used classroom project-based learning. Five respondents (19.23\%) used classroom discussion. Five respondents (19.23\%) classroom demonstration. Three respondents (11.54\%) used classroom inquiry. Two respondents (7.69\%) used the greenhouse laboratory and/or supervised practice. One respondent $(3.85 \%)$ does not teach the math skills. None of the respondents used biotechnology laboratory, land laboratory, forestry, other laboratory methods, library and/or computer lab, or field trip to teach adding, subtracting, multiplying, and dividing whole numbers, with and without a calculator (see Table 71).

Table 71

Methods Used to Teach Power. Structural and Technical CSS: Add, Subtract, Multiply, and Divide Whole Numbers, with and without a Calculator

\begin{tabular}{llll}
\hline Location & Method & $\mathrm{f}$ & $\%$ \\
\hline Classroom & Textbooks/handouts & 8 & 30.77 \\
Classroom & Lecture & 6 & 23.08 \\
Laboratory & Mechanics laboratory & 6 & 23.08 \\
Classroom & Project Based & 5 & 19.23 \\
Classroom & Discussion & 5 & 19.23 \\
Classroom & Demonstration & 5 & 19.23 \\
Classroom & Inquiry & 3 & 11.54 \\
Laboratory & Greenhouse & 2 & 7.69 \\
Other & Do not Teach & 1 & 3.85 \\
\hline
\end{tabular}


Table 71 (continued)

Methods Used to Teach Power. Structural and Technical CSS: Add, Subtract, Multiply, and Divide Whole Numbers, with and without a Calculator

\begin{tabular}{llll}
\hline Location & Method & $\mathrm{f}$ & $\%$ \\
\hline Laboratory & Meats laboratory & 0 & 0.00 \\
Laboratory & Biotechnology laboratory & 0 & 0.00 \\
Laboratory & Land laboratory & 0 & 0.00 \\
Laboratory & Forestry & 0 & 0.00 \\
Laboratory & Other & 0 & 0.00 \\
Other & Library/computer lab & 0 & 0.00 \\
Other & Field Trip & 0 & 0.00 \\
\hline
\end{tabular}

Basic Math Practices Used in the Power, Structural, and Technical Systems.

Seven respondents (26.92\%) used classroom demonstration to teach Basic Math Practices Used in the Power, Structural, and Technical Systems. Seven respondents $(26.92 \%)$ used classroom textbooks and/or handouts. Six respondents $(23.08 \%)$ used classroom lecture. Six respondents (23.08\%) used mechanics laboratory and/or supervised practice. Five respondents (19.23\%) used classroom project-based learning. Four respondents (15.38\%) used classroom discussion. Two respondents $(7.69 \%)$ used classroom inquiry. One respondent (3.85\%) used a greenhouse laboratory and/or supervised practice. One respondent (3.85\%) used a forestry laboratory and/or supervised practice. One respondent (3.85\%) used a library and/or computer lab. One respondent $(3.85 \%)$ did not teach math skills for Power and Tech. None of the respondents used meats laboratory, biotechnology laboratory, land laboratory, other laboratory methods, or 
field trip to teach basic math practices used in power, structural, and technical systems (see Table 72).

Table 72

Methods Used to Teach Power, Structural, and Technical CSS: Basic Math Practices used in Power, Structural, and Technical Systems

\begin{tabular}{|c|c|c|c|}
\hline Location & Method & $\mathrm{f}$ & $\%$ \\
\hline Classroom & Demonstration & 7 & 26.92 \\
\hline Classroom & Textbooks/handouts & 7 & 26.92 \\
\hline Classroom & Lecture & 6 & 23.08 \\
\hline Laboratory & Mechanics laboratory & 6 & 23.08 \\
\hline Classroom & Project Based & 5 & 19.23 \\
\hline Classroom & Discussion & 4 & 15.38 \\
\hline Classroom & Inquiry & 2 & 7.69 \\
\hline Laboratory & Greenhouse & 1 & 3.85 \\
\hline Laboratory & Forestry & 1 & 3.85 \\
\hline Other & Library/computer lab & 1 & 3.85 \\
\hline Other & Do not Teach & 1 & 3.85 \\
\hline Laboratory & Meats laboratory & 0 & 0.00 \\
\hline Laboratory & Biotechnology laboratory & 0 & 0.00 \\
\hline Laboratory & Land laboratory & 0 & 0.00 \\
\hline Laboratory & Other & 0 & 0.00 \\
\hline Other & Field Trip & 0 & 0.00 \\
\hline
\end{tabular}




\section{Construct a Project Using Hand Tools.}

Nine respondents $(34.62 \%)$ used mechanics laboratory and/or supervised practice to Construct a Project Using Hand Tools. Seven respondents $(26.92 \%)$ used classroom project-based learning. Seven respondents $(26.92 \%)$ used classroom demonstration. Six respondents (23.08\%) used classroom discussion. Five respondents (19.23\%) used classroom lecture. Five respondents (19.23\%) used classroom textbooks and/or handouts. Four respondents (15.38\%) used classroom inquiry. Three respondents (1154\%) do not teach students to construct a project using hand tools. Two respondents $(7.69 \%)$ used a greenhouse laboratory and/or supervised practice. One respondent (3.85\%) used a forestry laboratory and/or supervised practice. None of the respondents used meats laboratory, biotechnology laboratory, land laboratory, other laboratory methods, library and/or computer lab, or field trip to construct a project using hand tools (see Table 73).

Table 73

Methods Used to Teach Power, Structural, and Technical CSS: Construct a Project Using Hand Tools

\begin{tabular}{llll}
\hline Location & Method & f & $\%$ \\
\hline Laboratory & Mechanics laboratory & 9 & 34.62 \\
Classroom & Project Based & 7 & 26.92 \\
Classroom & Demonstration & 7 & 26.92 \\
Classroom & Discussion & 6 & 23.08 \\
Classroom & Lecture & 5 & 19.23 \\
Classroom & Textbooks/handouts & 5 & 19.23 \\
Classroom & Inquiry & 4 & 15.38 \\
Other & Do not Teach & 3 & 11.54 \\
\hline
\end{tabular}


Table 73 (continued)

Methods Used to Teach Power, Structural, and Technical CSS: Construct a Project Using Hand Tools

\begin{tabular}{llll}
\hline Location & Method & $\mathrm{f}$ & $\%$ \\
\hline Laboratory & Greenhouse & 2 & 7.69 \\
Laboratory & Forestry & 1 & 3.85 \\
Laboratory & Meats laboratory & 0 & 0.00 \\
Laboratory & Biotechnology laboratory & 0 & 0.00 \\
Laboratory & Land laboratory & 0 & 0.00 \\
Laboratory & Other & 0 & 0.00 \\
Other & Library/computer lab & 0 & 0.00 \\
Other & Field Trip & 0 & 0.00 \\
\hline
\end{tabular}

\section{Convert Decimals to Percentages and Percentages to Decimals.}

Six respondents $(23.08 \%)$ used classroom textbooks and/or handouts to Convert Decimals to Percentages and Percentages to Decimals. Five respondents (19.23\%) used classroom discussion. Five respondents (19.23\%) used classroom demonstration. Five respondents (19.23\%) used classroom lecture. Five respondents $(19.23 \%)$ used a mechanics laboratory and/or supervised practice. Three respondents $(11.54 \%)$ used classroom project-based learning. Three respondents (11.54\%) used classroom inquiry. Three respondents (11.54\%) used a greenhouse laboratory and/or supervised practice. Three respondents (11.54\%) do not teach conversion of decimals and percentages. One respondent (3.85\%) used a meats laboratory and/or supervised practice. None of the respondents used biotechnology laboratory, land laboratory, forestry, other laboratory 
methods, library and/or computer lab, or field trip to convert decimals to percentages and percentages to decimals (see Table 74).

Table 74

Methods Used to Teach Power, Structural, and Technical CSS: Convert Decimals to Percentages and Percentages to Decimals.

\begin{tabular}{|c|c|c|c|}
\hline Location & Method & $\mathrm{f}$ & $\%$ \\
\hline Classroom & Textbooks/handouts & 6 & 23.08 \\
\hline Classroom & Discussion & 5 & 19.23 \\
\hline Classroom & Demonstration & 5 & 19.23 \\
\hline Classroom & Lecture & 5 & 19.23 \\
\hline Laboratory & Mechanics laboratory & 5 & 19.23 \\
\hline Classroom & Project Based & 3 & 11.54 \\
\hline Classroom & Inquiry & 3 & 11.54 \\
\hline Laboratory & Greenhouse & 3 & 11.54 \\
\hline Other & Do not Teach & 3 & 11.54 \\
\hline Laboratory & Meats laboratory & 1 & 3.85 \\
\hline Laboratory & Biotechnology laboratory & 0 & 0.00 \\
\hline Laboratory & Land laboratory & 0 & 0.00 \\
\hline Laboratory & Forestry & 0 & 0.00 \\
\hline Laboratory & Other & 0 & 0.00 \\
\hline Other & Library/computer lab & 0 & 0.00 \\
\hline Other & Field Trip & 0 & 0.00 \\
\hline
\end{tabular}




\section{Convert Fractions to Decimals and Decimals to Fractions.}

Six respondents $(23.08 \%)$ used classroom textbooks and/or handouts to Convert Fractions to Decimals and Decimals to Fractions. Five respondents (19.23\%) used classroom lecture. Four respondents (15.38\%) used classroom discussion. Four respondents (15.38\%) used mechanics laboratory and/or supervised practice. Four respondents (15.38\%) do not teach conversion of fractions and decimals. Three respondents (11.54\%) used classroom inquiry. Two respondents $(7.69 \%)$ used classroom project based learning. One respondent (3.85\%) used a greenhouse laboratory and/or supervised practice. None of the respondents used meats laboratory, biotechnology laboratory, land laboratory, forestry, other laboratory methods, library and/or computer lab, or field trip to convert fractions to decimals and decimals to fractions (see Table 75). Table 75

Methods Used to Teach Power, Structural, and Technical CSS: Convert Fractions to Decimals and Decimals to Fractions

\begin{tabular}{lllc}
\hline Location & Method & $\mathrm{f}$ & $\%$ \\
\hline Classroom & Textbooks/handouts & 6 & 23.08 \\
Classroom & Lecture & 5 & 19.23 \\
Classroom & Discussion & 4 & 15.38 \\
Laboratory & Mechanics laboratory & 4 & 15.38 \\
Other & Do not Teach & 4 & 15.38 \\
Classroom & Inquiry & 3 & 11.54 \\
Classroom & Project Based & 2 & 7.69 \\
Laboratory & Greenhouse & 1 & 3.85 \\
\hline
\end{tabular}


Table 75 (continued)

Methods Used to Teach Power, Structural, and Technical CSS: Convert Fractions to Decimals and Decimals to Fractions

\begin{tabular}{llll}
\hline Location & Method & $\mathrm{f}$ & $\%$ \\
\hline Laboratory & Meats laboratory & 0 & 0.00 \\
Laboratory & Biotechnology laboratory & 0 & 0.00 \\
Laboratory & Land laboratory & 0 & 0.00 \\
Laboratory & Forestry & 0 & 0.00 \\
Laboratory & Other & 0 & 0.00 \\
Other & Library/computer lab & 0 & 0.00 \\
Other & Field Trip & 0 & 0.00 \\
\hline
\end{tabular}

\section{Proper and Safe Use of Hand Tools.}

Nine respondents (34.62\%) used classroom discussion to teach Proper and Safe Use of Hand tools. Nine respondents (34.62\%) used classroom demonstration. Nine respondents (34.62\%) used mechanics laboratory and/or supervised practice. Six respondents (23.08\%) used classroom project-based learning. Five respondents (19.23\%) used classroom lecture. Five respondents (19.23\%) used classroom textbooks and/or handouts. Four respondents (15.38\%) used classroom inquiry. Two respondents $(7.69 \%)$ used greenhouse laboratory and/or supervised practice. Two respondents (7.69\%) do not teach hand tool safety. One respondent (3.85\%) used a forestry laboratory and/or supervised practice. None of the respondents used meats laboratory, biotechnology laboratory, land laboratory, other laboratory methods, library and/or computer lab or field trip to teach proper and safe used of hand tools (see Table 76). 
Table 76

Methods Used to Teach Power, Structural, and Technical CSS: Properly and Safely Used Hand Tools

\begin{tabular}{|c|c|c|c|}
\hline Location & Method & $\mathrm{f}$ & $\%$ \\
\hline Classroom & Discussion & 9 & 34.62 \\
\hline Classroom & Demonstration & 9 & 34.62 \\
\hline Laboratory & Mechanics laboratory & 9 & 34.62 \\
\hline Classroom & Project Based & 6 & 23.08 \\
\hline Classroom & Lecture & 5 & 19.23 \\
\hline Classroom & Textbooks/handouts & 5 & 19.23 \\
\hline Classroom & Inquiry & 4 & 15.38 \\
\hline Laboratory & Greenhouse & 2 & 7.69 \\
\hline Other & Do not Teach & 2 & 7.69 \\
\hline Laboratory & Forestry & 1 & 3.85 \\
\hline Laboratory & Meats laboratory & 0 & 0.00 \\
\hline Laboratory & Biotechnology laboratory & 0 & 0.00 \\
\hline Laboratory & Land laboratory & 0 & 0.00 \\
\hline Laboratory & Other & 0 & 0.00 \\
\hline Other & Library/computer lab & 0 & 0.00 \\
\hline Other & Field Trip & 0 & 0.00 \\
\hline
\end{tabular}

\section{Basic Hand Tools and Their Proper Use in an Agricultural Setting.}

Eight respondents $(30.77 \%)$ used a mechanics laboratory and/or supervised practice to teach the Basic Hand Tools and Their Proper Use in an Agricultural Setting. Six respondents $(23.08 \%)$ used classroom discussion. Six respondents $(23.08 \%)$ used 
classroom demonstration. Six respondents (23.08\%) used classroom textbooks and/or handouts. Five respondents (19.23\%) used classroom project-based learning. Five respondents (19.23\%) used classroom lecture. Three respondents (11.54\%) used classroom inquiry. One respondent (3.85\%) used a greenhouse laboratory and/or supervised practice. One respondent (3.85\%) used a forestry laboratory and/or supervised practice. One respondent (3.85\%) does not teach basic hand tools and their proper use. None of the respondents used meats laboratory, biotechnology laboratory, land laboratory, other laboratory methods, or field trips to teach the basic hand tools and their proper use in an agricultural setting (see Table 77).

Table 77

Methods Used to Teach Power, Structural, and Technical CSS: The Basic Hand Tools and their Proper Used in an Agricultural Setting

\begin{tabular}{llcc}
\hline Location & Method & $\mathrm{f}$ & $\%$ \\
\hline Laboratory & Mechanics laboratory & 8 & 30.77 \\
Classroom & Discussion & 6 & 23.08 \\
Classroom & Demonstration & 6 & 23.08 \\
Classroom & Textbooks/handouts & 6 & 23.08 \\
Classroom & Project Based & 5 & 19.23 \\
Classroom & Lecture & 5 & 19.23 \\
Classroom & Inquiry & 3 & 11.54 \\
Laboratory & Greenhouse & 1 & 3.85 \\
Laboratory & Forestry & 1 & 3.85 \\
Other & Do not Teach & 1 & 3.85 \\
\hline
\end{tabular}


Table 77 (continued)

Methods Used to Teach Power, Structural, and Technical CSS: The Basic Hand Tools and their Proper Used in an Agricultural Setting

\begin{tabular}{llll}
\hline Location & Method & $\mathrm{f}$ & $\%$ \\
\hline Laboratory & Meats laboratory & 0 & 0.00 \\
Laboratory & Biotechnology laboratory & 0 & 0.00 \\
Laboratory & Land laboratory & 0 & 0.00 \\
Laboratory & Other & 0 & 0.00 \\
Other & Library/computer lab & 0 & 0.00 \\
Other & Field Trip & 0 & 0.00 \\
\hline
\end{tabular}

\section{Units of Weight, Volume, and Temperature.}

Six respondents (23.08\%) used classroom lecture to teach Units of weight, volume, and temperature. Six respondents (23.08\%) used classroom textbooks and/or handouts. Five respondents (19.23\%) used classroom discussion. Five respondents (19.23\%) used a mechanics laboratory and/or supervised practice. Four respondents (15.38\%) used classroom project-based learning. Three respondents $(11.54 \%)$ do not teach units of weight, volume, and temperature. Two respondents (7.69\%) used classroom inquiry. Two respondents (7.69\%) used classroom demonstration. One respondent (3.85\%) used a meats laboratory and/or supervised practice. One respondent (3.85\%) used a biotechnology laboratory and/or supervised practice. None of the respondents used greenhouse, land laboratory, forestry, other laboratory methods, library and/or computer lab or field trip to teach units of weight, volume, and temperature (see Table 78). 
Table 78

Methods Used to Teach Power, Structural, and Technical CSS: Units of Weight, Volume, and Temperature

\begin{tabular}{|c|c|c|c|}
\hline Location & Method & $\mathrm{f}$ & $\%$ \\
\hline Classroom & Lecture & 6 & 23.08 \\
\hline Classroom & Textbooks/handouts & 6 & 23.08 \\
\hline Classroom & Discussion & 5 & 19.23 \\
\hline Laboratory & Mechanics laboratory & 5 & 19.23 \\
\hline Classroom & Project Based & 4 & 15.38 \\
\hline Other & Do not Teach & 3 & 11.54 \\
\hline Classroom & Inquiry & 2 & 7.69 \\
\hline Classroom & Demonstration & 2 & 7.69 \\
\hline Laboratory & Meats laboratory & 1 & 3.85 \\
\hline Laboratory & $\begin{array}{l}\text { Biotechnology } \\
\text { laboratory }\end{array}$ & 1 & 3.85 \\
\hline Laboratory & Greenhouse & 0 & 0.00 \\
\hline Laboratory & Land laboratory & 0 & 0.00 \\
\hline Laboratory & Forestry & 0 & 0.00 \\
\hline Laboratory & Other & 0 & 0.00 \\
\hline Other & Library/computer lab & 0 & 0.00 \\
\hline Other & Field Trip & 0 & 0.00 \\
\hline
\end{tabular}

Use of a Ruler, a Metric Ruler, and a Measuring Tape to Measure.

Eight respondents $(30.77 \%)$ used classroom demonstration to the Use of a Ruler, a Metric Ruler, and a Measuring Tape to Measure. Seven respondents (26.92\%) used a 
mechanics laboratory and/or supervised practice. Six respondents (23.08\%) used classroom project-based learning. Six respondents (23.08\%) used classroom discussion. Six respondents (23.08\%) used classroom lecture. Six respondents $(23.08 \%)$ classroom textbooks and/or handouts. Three respondents (11.54\%) used classroom inquiry. Two respondents (7.69\%) used greenhouse laboratory and/or supervised practice. One respondent (3.85\%) used a meats laboratory and/or supervised practice. One respondent (3.85\%) used a forestry laboratory and/or supervised practice. One respondent (3.85\%) does not teach used of a ruler and measuring tape. None of the respondents used biotechnology laboratory, land laboratory, other laboratory methods, library and/or computer lab or field trip to teach the use of a ruler, a metric ruler, and a measuring tape to measure (see Table 79).

Table 79

Methods Used to Teach Power, Structural, and Technical CSS: Used a Ruler, a Metric Ruler, and a Measuring Tape to Measure

\begin{tabular}{llll}
\hline Location & Method & $\mathrm{f}$ & $\%$ \\
\hline Classroom & Demonstration & 8 & 30.77 \\
Laboratory & Mechanics laboratory & 7 & 26.92 \\
Classroom & Project Based & 6 & 23.08 \\
Classroom & Discussion & 6 & 23.08 \\
Classroom & Lecture & 6 & 23.08 \\
Classroom & Textbooks/handouts & 6 & 23.08 \\
Classroom & Inquiry & 3 & 11.54 \\
Laboratory & Greenhouse & 2 & 7.69 \\
Laboratory & Meats laboratory & 1 & 3.85 \\
\hline
\end{tabular}


Table 79 (continued)

Methods Used to Teach Power, Structural, and Technical CSS: Used a Ruler, a Metric Ruler, and a Measuring Tape to Measure

\begin{tabular}{llll}
\hline Location & Method & $\mathrm{f}$ & $\%$ \\
\hline Laboratory & Forestry & 1 & 3.85 \\
Other & Do not Teach & 1 & 3.85 \\
Laboratory & Biotechnology laboratory & 0 & 0.00 \\
Laboratory & Land laboratory & 0 & 0.00 \\
Laboratory & Other & 0 & 0.00 \\
Other & Library/computer lab & 0 & 0.00 \\
Other & Field Trip & 0 & 0.00 \\
\hline
\end{tabular}

\section{Recite the FFA Creed.}

Twelve respondents (46.15\%) used the classroom project-based learning to Recite the FFA Creed. Eight respondents (30.77\%) used classroom discussion. Seven respondents $(26.92 \%)$ used classroom lecture. Six respondents $(23.08 \%)$ used classroom demonstration. Six respondents $(23.08 \%)$ used classroom demonstration. Two respondents $(7.69 \%)$ used classroom inquiry. One respondent $(3.85 \%)$ used a library and/or computer lab. One respondent (3.85\%) used field trip. None of the respondents used mechanics laboratory, greenhouse, meats laboratory, biotechnology laboratory, land laboratory, forestry, or other laboratory methods. All respondents teach recitation of the FFA Creed (see Table 80). 
Table 80

Methods Used to Teach Leadership CSS: Recite the FFA Creed

\begin{tabular}{llcc}
\hline Location & Method & $\mathrm{f}$ & $\%$ \\
Classroom & Project Based & 12 & 46.15 \\
Classroom & Discussion & 8 & 30.77 \\
Classroom & Lecture & 7 & 26.92 \\
Classroom & Demonstration & 6 & 23.08 \\
Classroom & Textbooks/handouts & 6 & 23.08 \\
Classroom & Inquiry & 2 & 7.69 \\
Other & Library/computer lab & 1 & 3.85 \\
Other & Field Trip & 1 & 3.85 \\
Laboratory & Mechanics laboratory & 0 & 0.00 \\
Laboratory & Greenhouse & 0 & 0.00 \\
Laboratory & Meats laboratory & 0 & 0.00 \\
Laboratory & Biotechnology laboratory & 0 & 0.00 \\
Laboratory & Land laboratory & 0 & 0.00 \\
Laboratory & Forestry & 0 & 0.00 \\
Laboratory & Other & 0 & 0.00 \\
Other & Do not Teach & 0 & 0.00 \\
\hline
\end{tabular}

\section{Recite the FFA Motto.}

Twelve respondents (46.15\%) used classroom project based learning to Recite the FFA Motto. Eight respondents (30.77\%) used classroom lecture. Seven respondents (26.92\%) used classroom discussion. Six respondents $(23.08 \%)$ used classroom demonstration. Five respondents (19.23\%) used classroom inquiry. One respondent 
(3.85\%) used a library and/or computer lab. None of the respondents used mechanics laboratory, greenhouse, meats laboratory, biotechnology laboratory, land laboratory, forestry, other laboratory methods, or field trip. All respondents teach students to recite the FFA Motto (see Table 81).

Table 81

Methods Used to Teach Leadership CSS: Recite the FFA Moto

\begin{tabular}{llcl}
\hline Location & Method & $\mathrm{f}$ & $\%$ \\
\hline Classroom & Project Based & 12 & 46.15 \\
Classroom & Lecture & 8 & 30.77 \\
Classroom & Discussion & 7 & 26.92 \\
Classroom & Demonstration & 6 & 23.08 \\
Classroom & Textbooks/handouts & 5 & 19.23 \\
Classroom & Inquiry & 2 & 7.69 \\
Other & Library/computer lab & 1 & 3.85 \\
Laboratory & Mechanics laboratory & 0 & 0.00 \\
Laboratory & Greenhouse & 0 & 0.00 \\
Laboratory & Meats laboratory & 0 & 0.00 \\
Laboratory & Biotechnology laboratory & 0 & 0.00 \\
Laboratory & Land laboratory & 0 & 0.00 \\
Laboratory & Forestry & 0 & 0.00 \\
Laboratory & Other & 0 & 0.00 \\
Other & Field Trip & 0 & 0.00 \\
Other & Do not Teach & 0 & 0.00 \\
\hline
\end{tabular}




\section{Research the Important Dates and Events in the History of FFA and}

\section{Agricultural Education.}

Ten respondents (38.46\%) used classroom project based learning to Research the Important Dates and Events in the History of FFA and Agricultural Education. Eight respondents (30.77\%) used classroom discussion. Eight respondents (30.77\%) used classroom lecture. Six respondents (23.08\%) used classroom textbooks and/or handouts. Five respondents (19.23\%) used classroom inquiry. Three respondents (11.54\%) used library and/or computer lab. None of the respondents used mechanics laboratory, greenhouse, meats laboratory, biotechnology laboratory, land laboratory, forestry, other laboratory methods, or field trip; and none indicated that he/she does not teach important dates and events in FFA and agricultural education history (see Table 82).

Table 82

Methods Used to Teach Leadership CSS: Research the Important Dates and Events in the History of FFA and Agricultural Education

\begin{tabular}{llll}
\hline Location & Method & $\mathrm{f}$ & $\%$ \\
\hline Classroom & Project Based & 10 & 38.46 \\
Classroom & Discussion & 8 & 30.77 \\
Classroom & Lecture & 8 & 30.77 \\
Classroom & Textbooks/handouts & 6 & 23.08 \\
Classroom & Inquiry & 5 & 19.23 \\
Other & Library/computer lab & 3 & 11.54 \\
Laboratory & Mechanics laboratory & 0 & 0.00 \\
Laboratory & Greenhouse & 0 & 0.00 \\
Laboratory & Meats laboratory & 0 & 0.00 \\
\hline
\end{tabular}


Table 82 (continued)

Methods Used to Teach Leadership CSS: Research the Important Dates and Events in the History of FFA and Agricultural Education

\begin{tabular}{llll}
\hline Location & Method & $\mathrm{f}$ & $\%$ \\
\hline Laboratory & Biotechnology laboratory & 0 & 0.00 \\
Laboratory & Land laboratory & 0 & 0.00 \\
Laboratory & Forestry & 0 & 0.00 \\
Laboratory & Other & 0 & 0.00 \\
Other & Field Trip & 0 & 0.00 \\
Other & Do not Teach & 0 & 0.00 \\
\hline
\end{tabular}

Demonstrate Knowledge of FFA History, Code of Ethics, and Official Dress.

Eleven respondents (42.31\%) used classroom lecture to Demonstrate Knowledge of FFA history, Code of Ethics, and Official Dress. Ten respondents (38.46\%) used classroom discussion. Nine respondents (34.62\%) used classroom project-based learning. Nine respondents (34.62\%) used classroom textbooks and/or handouts. Five respondents (19.23\%) used classroom demonstration. One respondent (3.85\%) used classroom inquiry. One respondent (3.85\%) used other laboratory and/or supervised practice. One respondent (3.85\%) used a library and/or computer lab. One respondent (3.85\%) used field trip. None of the respondents used mechanics laboratory, greenhouse, meats laboratory, biotechnology laboratory, land laboratory, or forestry; and none indicates that he/she does not teach FFA history, Code of Ethics, and official dress (see Table 83). 
Table 83

Methods Used to Teach Leadership CSS: Students will Demonstrate Knowledge of FFA History, Code of Ethics, and Official Dress.

\begin{tabular}{|c|c|c|c|}
\hline Location & Methods & $f$ & $\%$ \\
\hline Classroom & Lecture & 11 & 42.31 \\
\hline Classroom & Discussion & 10 & 38.46 \\
\hline Classroom & Project Based & 9 & 34.62 \\
\hline Classroom & Textbooks/handouts & 9 & 34.62 \\
\hline Classroom & Demonstration & 5 & 19.23 \\
\hline Classroom & Inquiry & 1 & 3.85 \\
\hline Laboratory & Other & 1 & 3.85 \\
\hline Other & Library/computer lab & 1 & 3.85 \\
\hline Other & Field Trip & 1 & 3.85 \\
\hline Laboratory & Mechanics laboratory & 0 & 0.00 \\
\hline Laboratory & Greenhouse & 0 & 0.00 \\
\hline Laboratory & Meats laboratory & 0 & 0.00 \\
\hline Laboratory & Biotechnology laboratory & 0 & 0.00 \\
\hline Laboratory & Land laboratory & 0 & 0.00 \\
\hline Laboratory & Forestry & 0 & 0.00 \\
\hline Other & Do not Teach & 0 & 0.00 \\
\hline
\end{tabular}

\section{Percentage of Teachers Using Various Teaching Strategies}

The percentage of respondents using each teaching strategy on individual content skill sets was reported in the previous narrative and tables. In an attempt to determine the overall use of each teaching strategy by the respondents an overall average was 
calculated. The average percentage of respondents using the strategy, as well as the range of percentages are reported.

Project based learning had an average percentage of respondents using the strategy of $26.53 \%(\mathrm{SD}=15.93)$ with a range of use between $0.00 \%$ and $84.62 \%$. The average percentage of respondents using inquiry based instruction was $15.33 \%$ (SD = 6.65) with a range of use between $3.85 \%$ and $38.46 \%$. The use of discussions as a teaching technique ranged from $3.85 \%$ to $57.69 \%$ with an average of $30.48(\mathrm{SD}=10.84)$. Demonstrations had an average percentage of respondents using the strategy of $10.91 \%$ $(\mathrm{SD}=9.31)$ with a range of use between $0.00 \%$ and $34.62 \%$. The average percentage of respondents using lecture was $28.43 \%$ ( $\mathrm{SD}=9.80$ ) with a range of use between $7.69 \%$ and $50.00 \%$. The use of textbooks/handouts as a teaching technique ranged from $3.85 \%$ to $42.31 \%$ with an average of $26.10(\mathrm{SD}=8.35)$.

Mechanics laboratory had an average percentage of respondents using the strategy of $4.87 \%(\mathrm{SD}=9.15)$ with a range of use between $0.00 \%$ and $34.62 \%$. The average percentage of respondents using a greenhouse was $9.40 \%(\mathrm{SD}=12.57)$ with a range of use between $0.00 \%$ and $12.57 \%$. The use of a meats laboratory as a teaching technique ranged from $0.00 \%$ to $23.08 \%$ with an average of $4.19 \%(\mathrm{SD}=5.75)$. Biotechnology laboratory had an average percentage of respondents using the strategy of $1.90 \%$ ( $\mathrm{SD}=$ 3.01 ) with a range of use between $0.00 \%$ and $11.54 \%$. The average percentage of respondents using a land laboratory was $1.07 \%(\mathrm{SD}=3.01)$ with a range of use between $0.00 \%$ and $15.38 \%$. The use of a forestry laboratory as a teaching technique ranged from $0.00 \%$ to $7.69 \%$ with an average of $1.02 \%(\mathrm{SD}=1.92)$. Other laboratory had an average 
percentage of respondents using the strategy of $1.66 \%(\mathrm{SD}=3.00)$ with a range of use between $0.00 \%$ and $15.38 \%$.

Library/computer laboratory had an average percentage of respondents using the strategy of $7.89 \%(\mathrm{SD}=10.89)$ with a range of use between $0.00 \%$ and $46.15 \%$. The average percentage of respondents using field trips was $1.80 \%(\mathrm{SD}=3.63)$ with a range of use between $0.00 \%$ and $19.23 \%$. The percentage of respondents who did not teach the content skill set ranged from $0.00 \%$ to $30.77 \%$ with an average of $5.02 \%(\mathrm{SD}=5.95)$.

The data shows that some agricultural education teachers are incorporating some experiential learning into their classes with laboratories and project-based learning. Some teachers are still using classroom lecture, worksheets, and handouts to teach some aspects of agricultural education, such as the majority of the CSS for Introduction to Agriculture, Food and Natural Resources. The students must be able to tie theory to practical application. A classroom discussion about hand tool safety is not the same as the students' actually using the tools to learn the feel of them and their proper uses in agriculture. From the time it was first taught in public schools, agricultural education was intended to be a hands-on learning experience Teachers who are actively teaching, using the facilities available, are more likely to encourage students to become active learners and problem solvers. 
Table 84

Percentage of Teachers Using Various Teaching Strategies Across All CSSs

\begin{tabular}{|c|c|c|c|c|}
\hline & \multicolumn{4}{|c|}{ Percent Used } \\
\hline & M & SD & Min & Max \\
\hline Project Based & 26.53 & 15.93 & .00 & 84.62 \\
\hline Inquiry & 15.33 & 6.65 & 3.85 & 38.46 \\
\hline Discussion & 30.48 & 10.84 & 3.85 & 57.69 \\
\hline Demonstration & 10.91 & 9.31 & .00 & 34.62 \\
\hline Lecture & 28.43 & 9.80 & 7.69 & 50.00 \\
\hline Textbooks Handouts & 26.10 & 8.35 & 3.85 & 42.31 \\
\hline Mechanics & 4.87 & 9.15 & .00 & 34.62 \\
\hline Greenhouse & 9.40 & 12.57 & .00 & 46.15 \\
\hline Meats & 4.19 & 5.75 & .00 & 23.08 \\
\hline Biotechnology & 1.90 & 3.01 & .00 & 11.54 \\
\hline Land & 1.07 & 3.01 & .00 & 15.38 \\
\hline Forestry & 1.02 & 1.92 & .00 & 7.69 \\
\hline Other & 1.66 & 3.00 & .00 & 15.38 \\
\hline Library computer lab & 7.89 & 10.89 & .00 & 46.15 \\
\hline Field Trip & 1.80 & 3.63 & .00 & 19.23 \\
\hline Do not Teach & 5.02 & 5.95 & .00 & 30.77 \\
\hline
\end{tabular}




\section{CHAPTER V}

\section{Summary, Conclusions, and Recommendations}

\section{Summary}

Survey results show that respondents seem to employ a variety of hands-on experiences for students, as well as continuing to make use of traditional techniques such as lecture, library research, and work sheets, as indicated in a number of responses to the survey conducted for this thesis. The most worrisome response to the survey, however, is the number of times that "Do Not Teach" was marked as an answer to a question. This response seems to indicate that, far too often, state mandated CSS's are not being taught. Why? Is it because teachers do not have time, because they feel ill-prepared to teach all CSS's, or because they choose not to teach all CSS's?

While the number of surveys returned for this research project was smaller than the researcher had expected, informal discussions with agricultural educators at regional and state meetings lead the researcher to believe that answers provided by respondents are representative of many teachers in the state. For example, many tend to talk about projects their students complete in greenhouses and agricultural mechanics shops; and many help their students prepare for competitions in public speaking, parliamentary procedure, tractor driving, and FFA Creed. Some state that agricultural biotechnology allows for in-depth learning of scientific principles; and others note that team building, a critical component of scientific problem solving, is an integral part of agricultural education and of agri-business. Agricultural educators seem to indicate that students have opportunities to develop skills in many of these areas, and respondents' answers to questions asked on the survey seem to support such impressions. It is important to 
emphasize that respondents could mark multiple answers, indicating that they use multiple approaches to teaching CSS's; so someone who utilizes lecture or the textbook part of the time might also use multiple types of hands-on approaches to learning.

For example, to teach agribusiness, nearly $59 \%$ of agricultural education respondents used project based learning, 26\% used inquiry, almost 44\% employed discussion, nearly $28 \%$ made use of a greenhouse, and about $33 \%$ used the library, while nearly $35 \%$ still made use of classroom lecture. To teach animal systems, about $27 \%$ used project-based learning and $29 \%$ used classroom discussion while just over $29 \%$ used lecture and $27 \%$ used textbooks and handouts. Teachers used discussion $(35.17 \%)$ to teach agriculture innovation, almost $26 \%$ used textbooks and handouts, and a little more than $14 \%$ used inquiry. To teach about food products and processing, agriculture teachers used classroom lecture (27.97\%), classroom discussion (25.17\%), and textbooks/handouts $(18.18 \%)$, but only $12.24 \%$ used the meats laboratory.

Teachers used classroom discussion (39.42\%) to instruct about natural resources, while approximately $31 \%$ used classroom lecture and textbooks/handouts. To teach the plant systems, about $35 \%$ used textbooks/handouts, $28 \%$ of the teachers used the greenhouse laboratory, and about $27 \%$ used classroom discussion. Nearly $24 \%$ of teachers used a mechanics laboratory to teach the power, structural, and technical CSS's; $23.43 \%$ used classroom textbooks/handouts; and 20.63\% used classroom lecture as a preferred method of instruction. $41.35 \%$ used project-based learning to teach leadership, 32.69\% used classroom lecture, and 31.73\% used classroom discussion (see Appendix F). 


\section{Conclusions}

Greenhouses, crop fields, raised beds, agricultural mechanics projects that utilize wood and metal, equipment repair, meat labs, grounds maintenance, biotechnology learning, and many other types of educational experiences occur in agricultural education programs in middle and high schools across West Virginia. The degree to which experiential learning opportunities are made available to students and the types of learning opportunities vary from teacher to teacher, as shown in survey responses. The number of respondents with 5 to 10 years' teaching experience was $33.33 \%$, and the number with 16 to 20 years' experience was $26.67 \%$; therefore, the majority of respondents should have an impressive number of experiential opportunities to offer students. Returns on the study indicated that about half of the respondents did not teach introduction to agriculture, food, and natural resources, which might lead one to ask, "To what degree is there consistency in course offerings and in agricultural programs in West Virginia? Should there be? Or are the needs of students, community, and the agricultural industry in Randolph County so different from those in Wood County or Kanawha County that there is no need for consistency?"

Responses to the survey may also indicate indirectly that facilities vary widely from county to county, thereby affecting teachers' abilities to offer as many experiential learning opportunities as they might otherwise offer. The survey did not include questions about facilities, but perhaps it should have. Every school may not have a greenhouse or high tunnel. Every school may not have a shop with tools that are safe to use. Every school does not have a meat lab or equipment for biotechnology studies. Every school may not have a library as some librarians have gotten rid of books in favor 
of technology, and librarians have been replaced by directors of technology. Every school does not have access to tractors, land, and harvesting equipment to be used for growing crops. There seems to be no consistency in what courses are offered or in how courses are taught because there is no consistency in facilities or curriculum; however, regardless of limitations and challenges, agricultural educators seem to be finding ways to make their courses interesting and challenging, as indicated by answers provided by survey respondents.

The frequency with which teachers employ problem-based learning or any variety of types of hands-on learning versus lecture, worksheets, or textbook might be another question to explore in a more complex study that could employ multiple classroom observations. If anything, this study has illustrated the need for additional research to further explore the types, frequency, and effectiveness of hands-on learning in agricultural education classrooms.

\section{Recommendations}

More research is needed in how the CSS's in the agricultural education program are taught. Ideally, faculty and graduate students from universities, mentor teachers, and school administrators, could conduct multiple observations in agricultural education classrooms. A doctoral student and/or the College of Agriculture at West Virginia University could conduct such a study, not necessarily at every high school in the state, but at select schools. Key questions for the study might include, "Are the students actively learning about real world situations? If so, how? What are students doing, and what is the classroom teacher doing?" The response "Do Not Teach" should be addressed by the WVDE. If CSS's are not being taught, why not? In some cases, there might be a 
need for an additional agricultural education teacher. If the Introduction to Agriculture, Food, and Natural Resource Course is not being taught, why? Has the school moved to a CASE curriculum (Curriculum for Agricultural Science Education)? If so, are CSS's still being incorporated? Are there other reasons the course is not being taught?

Other questions might be, "Describe the facilities and equipment. If facilities and equipment seem inadequate, what makes them inadequate? How are the teachers and students compensating for inadequate facilities and equipment?" Feedback from trained observers on such questions could provide more valid information when coupled with feedback from teachers themselves.

The West Virginia Department of Education (WVDE) should make sure that all programs have the facilities to permit teachers to actively engage students, and make sure that facilities are kept up to date. Every school should have a library and a trained librarian to ensure that students and teachers have access to resources, print and nonprint, to research information about developments in professional, technical, and career fields. The WVDE should offer professional development programs to help the teachers develop curriculums and lessons that allow students "hands-on" learning that can be applied to real world situations. The current simulated workplace program is a good start, but should be expanded.

As answers to survey questions show, teachers used project-based learning more often than any other teaching approach. Teachers in the agricultural education programs were engaging the students. Teachers should find more ways to actively engage the students and to avoid too much reliance on textbook/handouts and classroom lectures. This researcher has become aware of some agricultural education teachers who are new 
to their positions, have gotten rid of facilities or equipment because they did not wish to teach a particular component of the agricultural education curriculum. A teacher should never be permitted to get rid of a greenhouse, a high tunnel, aqua-culture equipment, shop equipment, scientific research equipment, or any facility or equipment that can be used to actively engage students. If such equipment and facilities are available at a school, they should be incorporated into teaching the CSS's. Every school and county administration should be pro-active in securing and caring for needed equipment and facilities, and in accounting for equipment and facilities from year to year in order to benefit not only current students and teachers, but future students and teachers as well. 


\section{REFERENCES}

$150^{\text {th }}$ Anniversary - Celebrating Research (2017).

www.davis.wvu.edu/news/2017/02/14/150th-anniversary-celebrating-research.

Agricultural Education - Early Congressional Efforts: An Early Philosophy of Agricultural Education. (2016).

http://educationstateuniversity.com/pages/1740/agricultural-education.html

Arnold, S., Warner, W. J. \& Osborne, E. J. (2006). Experiential learning in secondary agricultural education classrooms. Journal of Southern Agricultural Education Research, 56(1), 30-39.

Ary, D., Jacobs, L., Sorensen, C. and Walker, D. (2014). Introduction to Research in Education, $9^{\text {th }}$ ed. Belmont, CA: Wadsworth Cengage Learning.

Burris, S. \& Garton, B. L. (2007). Effect of instructional strategy on critical thinking and content knowledge: Using problem-based learning in the secondary classroom. Journal of Agricultural Education, 49(1), 110-120.

Delay, A. M. \& Swan, B. G. (2014). Student apathy as defined by secondary agricultural education students. Journal of Agricultural Education. 55(1). 106-119.

Felder, R. M. \& Brent, D. (2005) Understanding student differences. Journal of Engineering Education. 94(1). 57-72. Retrieved from www.4ncsu.edu/unity/lockers/users/f/felder/public/papers/understandingdifferences.pdf.

Friere, P. (1997). Pedagogy of the oppressed. New York: Continuum Publishing.

Gilakjani, A. P. \& Ahmadi, S. M. (2011). The effect of visual, auditory, and kinesthetic learning styles on language teaching. IPEDR, 5 469-472.

Hillison, J. (1989).Congressional district schools: Forerunner of federally funded vocational agriculture. Journal of Agricultural Education, 7-13.

Hillison, J. (1995). The coalition that supported the Smith-Hughes Act or a case for strange bedfellows. Journal of Vocational and Technical Education, 11(2), 4-11

Kolb, A. \& Kolb, D. (2005). Learning styles and learning spaces: Enhancing experiential learning in higher education. Academy of Management Learning \& Education, 4(2), 193-212. Retrieved from www.learningfromexperience.com/media/2011/03/learning-styles-and-learningspace.pdf.

Miller, S. C. (2001). Learning styles. 4 Faculty.org. Retrieved from www.4faculty.org/includes/digdeeper/lessons4/learning styles. 
Myers, B. E., Dryer, J. E. \& Breja, L. M. (2014). Recruitment strategies and activities used by agriculture teacher. Journal of Agricultural Education, 44(4), 94-105.

National Academics. (2009). Transforming agricultural education for a changing world. Ncseonline.org.sites/default/files/.ag_education_final\%20(2).pdf.

National FFA Organization. (2014). Statistics. http://www.ask.com/wiki/NationalFFAOrganization.

North Carolina A\&T State University. (n. d.) The $125^{\text {th }}$ Second Morrill Act Anniversary Celebration at North Carolina A\&T State University/ Retrieved from http://morrill1890.ag.ncat.edu.

Place, N. T. (2015). Land Grant and Sea Grant: Events leading to the establishment of Land Grant Universities. University of Florida, Dept. of Agricultural Education and Communications. Retrieved from http://ifas.ufl.edu/events-leading-to-theestablishment-of-land-grant.pdf.

Ramsey, J. \& Edwards, M. C. (2004). Informal learning in science: Does agricultural education have a role? Journal of Southern Agricultural Education Research, 54(1), 86-99.

Saucier, P. R. \& McKine, B. R. (2011). Assessing the learning needs of student teachers in Texas regarding management of the agricultural mechanics laboratory: implications for the professional development of early career teachers in agricultural education. Journal of Agricultural Education, 52(4). 24-34.

Shoulders, C. \& Myers, B. (2012). Teachers' Used of Agricultural Laboratories in Secondary Agricultural Education. Journal of Agricultural Education, 53(2), 124138.

Walls, R. T. (1999). Effective teaching: Psychological Foundations of Learning. Morgantown: West Virginia University.

West Virginia Department of Education. (2015). Agriculture, food, and natural resource cluster. Retrieved from www.wvde.gov. 
APPENDIX A

Initial Contact Email 
November 14, 2017

Dear Fellow Agricultural Education Teachers:

In just a few days, you will receive a survey regarding agricultural education programs in West Virginia. I am conducting this research project as part of the requirements for the master's degree in agricultural education at West Virginia University. Your feedback could prove valuable to me and to many other teachers of agricultural education in West Virginia.

The survey concerns the recruitment and retention of students in agricultural education and focused specifically on the use of hand-on learning.

Thank you in advance for taking time to fill out the survey. It is only with your generous help and the help of other agricultural education teachers in the state that such a research project can succeed and that each of us can find ways to continue improving our programs and making involvement in agricultural education programs increasingly rewarding and meaningful for both teachers and students. I am especially excited to have the opportunity to learn from other teachers so that I can strengthen the program for which I am responsible.

According to research protocol and West Virginia University requirements, all information gathered from the survey will be kept strictly confidential,; and no school, county, or teacher will be referred to by name. In addition, if you like, I will gladly share research findings with you.

Sincerely,

Lee I. Wright

Graduate Student

Agricultural Education
Harry N. Boone, Jr. Ph.D.

Professor and Chair

Agricultural and Extension Education 
APPENDIX B

Cover Letter 
November 14, 2017

Dear Agricultural Education Teacher:

As an agricultural educator, you are an important part of the educational system and a vital contact for future young farmers in West Virginia. As an educator, you influence students in various aspects of agriculture, and your teaching is critical to their success, as well as to the success of the agricultural education program.

As you know from my initial contact letter, I am Lee I. Wright, a graduate student in the Agricultural and Extension Education program. Under the direction of Dr. Harry N. Boone, I am conducting a survey to determine the usefulness of hands-on learning in recruiting and retaining students in the agricultural education programs in West Virginia. The results of this study will be used to prepare a thesis to partially fulfill the requirements for a Master's of Science degree in Agricultural and Extension Education.

West Virginia secondary teachers of agricultural education are being asked to complete a survey for this study. The results will provide insight into recruiting and retaining students in secondary agricultural education programs. Please take a few moments to share your opinions.

Participation in this research study is completely voluntary, and all information provided will be kept confidential. The survey should take only about twenty minutes to complete. Your response to the survey is crucial to the success of the study. You may skip any question which you are not comfortable answering. You will notice a code number at the top left of the return envelope. This code will be used to identify nonrespondents for follow-up contact and will be destroyed before the details of the survey are analyzed. Survey results will be reported in a summary format, and individual responses will not be identifiable.

The Institutional Review Board (IRB) at West Virginia University has approved this study. If you have any questions or concerns about completing the survey or about being in this study, you may contact me at liwright@mix.wvu.edu, or you may phone 304-335-4575, extension 111.

Please return your completed survey prior to January 1, 2018. Thank you in advance for your assistance with this research effort. We sincerely appreciate your participation.

Sincerely,

Lee I. Wright

Graduate Student

Agricultural Education
Harry N. Boone, Jr, Ph.D.

Professor and Chair

Agricultural and Extension Education 
APPENDIX C

Follow Up Letter 
January 15, 2018

Dear Agricultural Education Teacher:

In November 2017, you received a survey regarding agricultural education programs in West Virginia. I am conducting this research project as part of the requirements for the master's degree in agricultural education at West Virginia University. Your feedback could prove valuable to me and to many other teachers of agricultural education in West Virginia.

As you know from my initial contact letter, I am Lee I. Wright, a graduate student in the Agricultural and Extension Education program; and under the direction of Dr. Harry N. Boone, Jr., we are conducting a survey to determine the usefulness of hands-on learning in recruiting and retaining students in the agricultural education programs in West Virginia. The results of this study will be used to prepare a thesis to partially fulfill the requirements for a Master's of Science degree in Agricultural and Extension Education.

West Virginia secondary teachers of agricultural education are being asked to complete a survey for this study. The results will provide insight into recruiting and retaining students in secondary agricultural education programs. Please take a few moments to share your opinions.

Participation in this research study is completely voluntary, and all information provided will be kept confidential. The survey should take only about twenty minutes to complete. Your response to the survey is crucial to the success of the study. You may skip any question which you are not comfortable answering. You will notice a code number at the top left of the return envelope. This code will be used to identify nonrespondents for follow-up contact and will be destroyed before the details of the survey are analyzed. Survey results will be reported in a summary format, and individual responses will not be identifiable.

The Institutional Review Board (IRB) at West Virginia University has approved this study. If you have any questions or concerns about completing the survey or about being in this study, you may contact me at liwright@mix.wvu.edu, or you may phone 304-335-4575, extension 111. Please place the completed survey in the enclosed, postage-paid, self-addressed return envelope and drop it in the mail. Please return your completed survey prior to January 15, 2018. Thank you in advance for your assistance with this research effort. We sincerely appreciate your participation.

Sincerely,

Lee I. Wright

Graduate Student
Harry N. Boone, Jr. Ph.D.

Professor and Chair 
APPENDIX D

Survey 
Default Question Block

Methods Used to

Teach Content Skill Sets Required for

Introduction to Agriculture, Food and Natural Resources

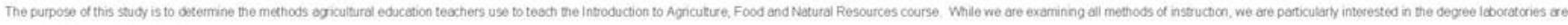
polized to instud studiants in the cours

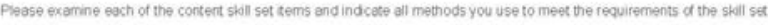

Do you teach the Introduction to Agriculture, Food and Natural Resources (WVEIS 0101) course?

Foundations of Agribusiness

\begin{tabular}{|c|c|c|c|c|c|c|c|c|c|c|c|c|c|c|c|c|}
\hline & \multicolumn{6}{|c|}{ Classroom } & \multicolumn{7}{|c|}{ Laboratory } & \multicolumn{3}{|c|}{ Other } \\
\hline & $\begin{array}{l}\text { Project } \\
\text { Based }\end{array}$ & Inquiry & Discussion & Demonstration & Lecture & $\begin{array}{l}\text { Textbooks/ } \\
\text { Handouts }\end{array}$ & Mechanies & Greenhouse & Meats & Biotechnology & Land & Forestry & Other & $\begin{array}{l}\text { Libranyl } \\
\text { computer } \\
\text { lab }\end{array}$ & $\underset{\text { Field }}{\text { Tip }}$ & $\begin{array}{c}\text { Do } \\
\text { not } \\
\text { Teach }\end{array}$ \\
\hline Types of agribusiness omnership & $\square$ & $\square$ & $\square$ & $\square$ & $\square$ & $\square$ & 口 & 口 & $\square$ & $\square$ & $\square$ & $\square$ & $\square$ & $\square$ & 口 & $\square$ \\
\hline Retum on investment & $\square$ & $\square$ & $\square$ & 口 & $\square$ & $\square$ & $\square$ & $\square$ & $\square$ & 口 & $\square$ & $\square$ & $\square$ & $\square$ & 口 & $\square$ \\
\hline $\begin{array}{l}\text { Methods of marketing agricultural } \\
\text { commosities, products and services in } \\
\text { domestic and intemational markets }\end{array}$ & $\square$ & $\square$ & $\square$ & $\square$ & $\square$ & $\square$ & $\square$ & $\square$ & $\square$ & $\square$ & $\square$ & $\square$ & $\square$ & $\square$ & 口 & $\square$ \\
\hline $\begin{array}{l}\text { Basic finance - personal inventory, net } \\
\text { worth, income, expense }\end{array}$ & $\square$ & $\square$ & $\square$ & $\square$ & $\square$ & $\square$ & $\square$ & $\square$ & $\square$ & $\square$ & $\square$ & $\square$ & $\square$ & $\square$ & $\square$ & $\square$ \\
\hline $\begin{array}{l}\text { Supervised Agnicultural Experience } \\
\text { Program (SAE) }\end{array}$ & $\square$ & $\square$ & $\square$ & $\square$ & $\square$ & $\square$ & $\square$ & $\square$ & $\square$ & $\square$ & $\square$ & $\square$ & $\square$ & $\square$ & $\square$ & $\square$ \\
\hline $\begin{array}{l}\text { The Four Ps (product, place, price and } \\
\text { promotion) }\end{array}$ & $\square$ & $\square$ & $\square$ & $\square$ & $\square$ & $\square$ & 口 & 口 & $\square$ & 口 & $\square$ & $\square$ & 口 & 口 & $\square$ & $\square$ \\
\hline $\begin{array}{l}\text { Create an advertisement for an } \\
\text { agricultural product }\end{array}$ & $\square$ & $\square$ & $\square$ & $\square$ & $\square$ & $\square$ & $\square$ & $\square$ & $\square$ & $\square$ & $\square$ & $\square$ & $\square$ & $\square$ & $\square$ & $\square$ \\
\hline $\begin{array}{l}\text { Research local supply and demand of } \\
\text { agricultural products }\end{array}$ & $\square$ & 口 & $\square$ & 口 & $\square$ & $\square$ & $\square$ & 口 & $\square$ & 口 & $\square$ & $\square$ & 口 & 口 & 口 & $\square$ \\
\hline $\begin{array}{l}\text { Create a plan for their own agricultural } \\
\text { enterprises }\end{array}$ & 口 & 口 & $\square$ & 口 & $\square$ & $\square$ & 口 & $\square$ & $\square$ & 口 & 口 & $\square$ & 口 & 口 & 口 & $\square$ \\
\hline
\end{tabular}




\begin{tabular}{|c|c|c|c|c|c|c|c|c|c|c|c|c|c|c|c|c|}
\hline & \multicolumn{6}{|c|}{ Classroom } & \multicolumn{7}{|c|}{ Laboratory/Supenvised Practice } & \multicolumn{3}{|c|}{ Other } \\
\hline & $\begin{array}{l}\text { Project } \\
\text { Based }\end{array}$ & Inquiry & Discussion & Demonstration & Lecture & $\begin{array}{l}\text { Textbooks/ } \\
\text { Handouts }\end{array}$ & Mechanics & Greenhouse & Meats & Biotechnology & Land & Forestry & Other & $\begin{array}{l}\text { Libranyl } \\
\text { computer } \\
\text { lab }\end{array}$ & $\begin{array}{l}\text { Field } \\
\text { Trip }\end{array}$ & $\begin{array}{l}\text { Do } \\
\text { not } \\
\text { Teach }\end{array}$ \\
\hline $\begin{array}{l}\text { The origin, significance, distribution } \\
\text { and domestication of animal systems }\end{array}$ & $\square$ & 口 & $\square$ & $\square$ & $\square$ & $\square$ & $\square$ & $\square$ & $\square$ & $\square$ & $\square$ & $\square$ & $\square$ & $\square$ & $\square$ & $\square$ \\
\hline $\begin{array}{l}\text { Common and scientific names of } \\
\text { major animal species }\end{array}$ & $\square$ & 口 & $\square$ & $\square$ & $\square$ & ㅁ & 口 & ㅁ & $\square$ & 口 & $\square$ & $\square$ & $\square$ & 口 & 口 & 口 \\
\hline Breeds of livestock & $\square$ & $\square$ & $\square$ & $\square$ & $\square$ & $\square$ & $\square$ & $\square$ & $\square$ & $\square$ & $\square$ & $\square$ & $\square$ & $\square$ & $\square$ & $\square$ \\
\hline Basic anatomy of animals & $\square$ & 口 & $\square$ & $\square$ & $\square$ & $\square$ & $\square$ & 口 & $\square$ & $\square$ & $\square$ & $\square$ & $\square$ & $\square$ & $\square$ & $\square$ \\
\hline $\begin{array}{l}\text { Livestock kemminology (steer, heifer, } \\
\text { barrow, gilt, etc.) }\end{array}$ & $\square$ & $\square$ & $\square$ & $\square$ & $\square$ & $\square$ & $\square$ & $\square$ & $\square$ & $\square$ & $\square$ & $\square$ & $\square$ & $\square$ & $\square$ & $\square$ \\
\hline Animal cells & 口 & 口 & $\square$ & $\square$ & $\square$ & 口 & 口 & 口 & $\square$ & 口 & $\square$ & $\square$ & 口 & 口 & 口 & 口 \\
\hline Animal health disorders & 口 & 口 & $\square$ & $\square$ & $\square$ & 口 & 口 & 口 & $\square$ & 口 & $\square$ & $\square$ & 口 & 口 & 口 & 口 \\
\hline Bio-security in the animal industry & $\square$ & $\square$ & $\square$ & $\square$ & $\square$ & $\square$ & $\square$ & $\square$ & $\square$ & $\square$ & $\square$ & $\square$ & $\square$ & $\square$ & $\square$ & $\square$ \\
\hline Common types of feedstuffs & $\square$ & 口 & $\square$ & $\square$ & $\square$ & $\square$ & $\square$ & $\square$ & $\square$ & 口 & $\square$ & $\square$ & $\square$ & $\square$ & $\square$ & $\square$ \\
\hline Animal welfare and animal rights & $\square$ & $\square$ & $\square$ & $\square$ & $\square$ & $\square$ & $\square$ & $\square$ & $\square$ & $\square$ & $\square$ & $\square$ & $\square$ & $\square$ & $\square$ & $\square$ \\
\hline $\begin{array}{l}\text { Facilities needed to house and } \\
\text { produce animal species safely and } \\
\text { efficiently }\end{array}$ & $\square$ & 口 & $\square$ & $\square$ & $\square$ & $\square$ & $\square$ & $\square$ & $\square$ & $\square$ & $\square$ & $\square$ & $\square$ & $\square$ & $\square$ & $\square$ \\
\hline $\begin{array}{l}\text { Effects of animal agriculture on the } \\
\text { environment }\end{array}$ & $\square$ & $\square$ & $\square$ & $\square$ & $\square$ & $\square$ & $\square$ & $\square$ & $\square$ & $\square$ & $\square$ & $\square$ & $\square$ & $\square$ & $\square$ & $\square$ \\
\hline $\begin{array}{l}\text { Diagram a typical animal cell and } \\
\text { identify the organelles }\end{array}$ & $\square$ & $\square$ & $\square$ & $\square$ & $\square$ & $\square$ & $\square$ & $\square$ & $\square$ & $\square$ & $\square$ & $\square$ & $\square$ & $\square$ & $\square$ & $\square$ \\
\hline Practice administering injections & $\square$ & $\square$ & $\square$ & $\square$ & $\square$ & $\square$ & $\square$ & $\square$ & $\square$ & $\square$ & $\square$ & $\square$ & $\square$ & $\square$ & $\square$ & $\square$ \\
\hline $\begin{array}{l}\text { Perform a basic health exam on a live } \\
\text { animal }\end{array}$ & $\square$ & $\square$ & $\square$ & $\square$ & $\square$ & $\square$ & $\square$ & $\square$ & $\square$ & $\square$ & $\square$ & $\square$ & $\square$ & $\square$ & $\square$ & $\square$ \\
\hline $\begin{array}{l}\text { Debate the issues associated with } \\
\text { animal welfare and animal rights }\end{array}$ & $\square$ & $\square$ & $\square$ & $\square$ & $\square$ & $\square$ & 口 & 口 & $\square$ & $\square$ & $\square$ & 口 & $\square$ & $\square$ & 口 & 口 \\
\hline
\end{tabular}

Agriculture Innovation and Technology

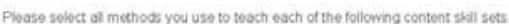

$$
\begin{aligned}
& \text { Classroom } \\
& \text { Laboratory/Supervised Practice }
\end{aligned}
$$

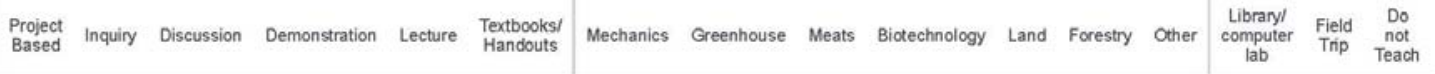

$$
\begin{aligned}
& \text { Agricultural biotechnology } \\
& \square \quad \square \quad \square \\
& \square \quad \square \\
& \text { 문 } \\
& \square \quad \square
\end{aligned}
$$




\begin{tabular}{|c|c|c|c|c|c|c|c|c|c|c|c|c|c|c|c|c|}
\hline \multirow[t]{3}{*}{$3 / 13 / 2019$} & \multicolumn{16}{|c|}{ Qualtrics Survey Software } \\
\hline & \multicolumn{6}{|c|}{ Classroom } & \multicolumn{7}{|c|}{ Laboratory/Supenised Practice } & \multicolumn{3}{|c|}{ Other } \\
\hline & $\begin{array}{l}\text { Project } \\
\text { Based }\end{array}$ & Inquiry & Discussion & Demonstration & Lecture & $\begin{array}{l}\text { Textbooks/ } \\
\text { Handouts }\end{array}$ & Mechanics & Greenhouse & Meats & Biotechnology & Land & Forestry & Other & $\begin{array}{c}\text { Libranyl } \\
\text { computer } \\
\text { lab }\end{array}$ & $\begin{array}{c}\text { Field } \\
\text { Trip }\end{array}$ & $\begin{array}{c}\text { Do } \\
\text { not } \\
\text { Teach }\end{array}$ \\
\hline $\begin{array}{l}\text { Applications of biotechnology in } \\
\text { agriculture }\end{array}$ & 口 & 口 & ㅁ & 口 & ㅁ & 口 & 口 & $\square$ & $\square$ & 口 & $\square$ & $\square$ & $\square$ & $\square$ & $\square$ & 口 \\
\hline The history of agriculture innovation & $\square$ & 口 & $\square$ & $\square$ & $\square$ & $\square$ & 口 & 口 & $\square$ & $\square$ & $\square$ & $\square$ & $\square$ & $\square$ & 口 & 口 \\
\hline $\begin{array}{l}\text { The major agriculture inventions and } \\
\text { their impact on the industry. }\end{array}$ & $\square$ & 口 & $\square$ & $\square$ & $\square$ & $\square$ & $\square$ & $\square$ & $\square$ & $\square$ & $\square$ & $\square$ & $\square$ & $\square$ & $\square$ & $\square$ \\
\hline $\begin{array}{l}\text { Use agricultural related technology } \\
\text { and equipment }\end{array}$ & $\square$ & $\square$ & $\square$ & $\square$ & $\square$ & $\square$ & $\square$ & $\square$ & $\square$ & $\square$ & $\square$ & $\square$ & $\square$ & $\square$ & $\square$ & $\square$ \\
\hline $\begin{array}{l}\text { Debate the issues associated with } \\
\text { biotechnology }\end{array}$ & $\square$ & 口 & $\square$ & $\square$ & $\square$ & $\square$ & 口 & 口 & $\square$ & 口 & $\square$ & $\square$ & $\square$ & $\square$ & $\square$ & $\square$ \\
\hline $\begin{array}{l}\text { Research current agricultural products } \\
\text { impacted by biotechnology practices }\end{array}$ & $\square$ & 口 & $\square$ & $\square$ & $\square$ & $\square$ & $\square$ & 口 & $\square$ & $\square$ & $\square$ & $\square$ & $\square$ & $\square$ & 口 & $\square$ \\
\hline
\end{tabular}

Foundations of Food Products and Processing

\begin{tabular}{|c|c|c|c|c|c|c|c|c|c|c|c|c|c|c|c|c|}
\hline & \multicolumn{6}{|c|}{ Classroom } & \multicolumn{7}{|c|}{ Laboratory/Supenvised Practice } & \multicolumn{3}{|c|}{ Other } \\
\hline & $\begin{array}{l}\text { Project } \\
\text { Based }\end{array}$ & Inquiry & Discussion & Demonstration & Lecture & $\begin{array}{l}\text { Textbooks/ } \\
\text { Handouts }\end{array}$ & Mechanics & Greenhouse & Meats & Biotechnology & Land & Forestry & Other & $\begin{array}{c}\text { Libraryl } \\
\text { computer } \\
\text { lab }\end{array}$ & $\begin{array}{l}\text { Field } \\
\text { Trip }\end{array}$ & $\begin{array}{c}\text { Do } \\
\text { not } \\
\text { Teach }\end{array}$ \\
\hline $\begin{array}{l}\text { The history of the animal processing } \\
\text { industry }\end{array}$ & $\square$ & $\square$ & $\square$ & $\square$ & $\square$ & $\square$ & $\square$ & 口 & $\square$ & $\square$ & $\square$ & $\square$ & $\square$ & $\square$ & $\square$ & $\square$ \\
\hline $\begin{array}{l}\text { The importance of food labeling to the } \\
\text { consumer }\end{array}$ & $\square$ & ם & $\square$ & $\square$ & $\square$ & $\square$ & $\square$ & $\square$ & $\square$ & $\square$ & $\square$ & $\square$ & $\square$ & $\square$ & $\square$ & $\square$ \\
\hline $\begin{array}{l}\text { Quality and yield grades of food } \\
\text { products }\end{array}$ & $\square$ & $\square$ & $\square$ & $\square$ & $\square$ & $\square$ & $\square$ & $\square$ & $\square$ & $\square$ & $\square$ & $\square$ & $\square$ & $\square$ & $\square$ & $\square$ \\
\hline $\begin{array}{l}\text { Foods derived from meat, egg, } \\
\text { poultry, fish and dairy products }\end{array}$ & $\square$ & 口 & $\square$ & $\square$ & $\square$ & $\square$ & 口 & $\square$ & $\square$ & $\square$ & $\square$ & $\square$ & $\square$ & $\square$ & $\square$ & $\square$ \\
\hline $\begin{array}{l}\text { Products derived from fruits and } \\
\text { vegtables }\end{array}$ & $\square$ & $\square$ & $\square$ & $\square$ & $\square$ & $\square$ & $\square$ & $\square$ & $\square$ & $\square$ & $\square$ & $\square$ & $\square$ & $\square$ & $\square$ & $\square$ \\
\hline $\begin{array}{l}\text { Products derived from grains. } \\
\text { legumes and oilseeds }\end{array}$ & $\square$ & 口 & $\square$ & $\square$ & $\square$ & $\square$ & $\square$ & $\square$ & $\square$ & $\square$ & $\square$ & $\square$ & $\square$ & $\square$ & 口 & $\square$ \\
\hline $\begin{array}{l}\text { Common weights and measures in the } \\
\text { food products and processing industry }\end{array}$ & $\square$ & $\square$ & $\square$ & $\square$ & $\square$ & $\square$ & $\square$ & $\square$ & $\square$ & $\square$ & $\square$ & $\square$ & $\square$ & $\square$ & $\square$ & $\square$ \\
\hline Methods of food preservations & $\square$ & 口 & $\square$ & $\square$ & $\square$ & $\square$ & $\square$ & $\square$ & $\square$ & $\square$ & $\square$ & $\square$ & $\square$ & $\square$ & $\square$ & $\square$ \\
\hline $\begin{array}{l}\text { Produce a food product (cheese, } \\
\text { sausage, sauerkraut, etc.) }\end{array}$ & $\square$ & $\square$ & $\square$ & $\square$ & $\square$ & $\square$ & $\square$ & 口 & $\square$ & $\square$ & $\square$ & $\square$ & $\square$ & $\square$ & $\square$ & $\square$ \\
\hline $\begin{array}{l}\text { Compare and contrast various food } \\
\text { labels }\end{array}$ & $\square$ & ם & $\square$ & $\square$ & $\square$ & $\square$ & $\square$ & 口 & $\square$ & $\square$ & $\square$ & 口 & 口 & 口 & 口 & 口 \\
\hline
\end{tabular}




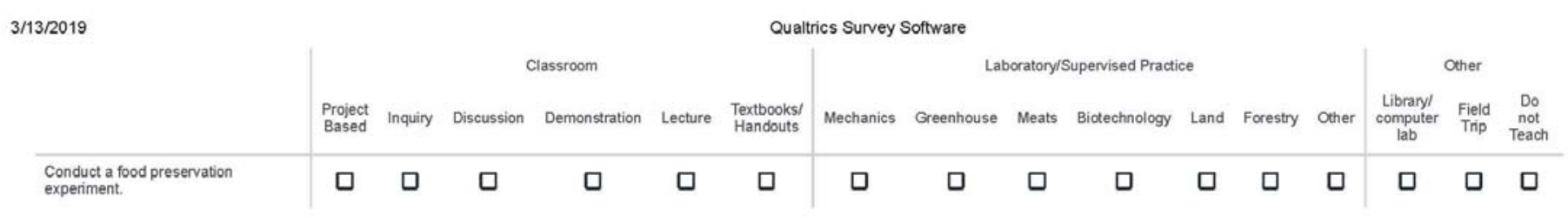

Foundations of Natural Resources

\begin{tabular}{|c|c|c|c|c|c|c|c|c|c|c|c|c|c|c|c|c|}
\hline & \multicolumn{6}{|c|}{ Classroom } & \multicolumn{7}{|c|}{ Laboratory/Supervised Practice } & \multicolumn{3}{|c|}{ Other } \\
\hline & $\begin{array}{l}\text { Project } \\
\text { Based }\end{array}$ & Inquiry & Discussion & Demonstration & Lecture & $\begin{array}{l}\text { Textbooks/ } \\
\text { Handouts }\end{array}$ & Mechanics & Greenhouse & Meats & Biotechnology & Land & Forestry & Other & $\begin{array}{c}\text { Libraryl } \\
\text { computer } \\
\text { lab }\end{array}$ & $\begin{array}{l}\text { Field } \\
\text { Trip }\end{array}$ & $\begin{array}{c}\text { Do } \\
\text { not } \\
\text { Teach }\end{array}$ \\
\hline Natural resources & $\square$ & $\square$ & $\square$ & $\square$ & $\square$ & $\square$ & $\square$ & $\square$ & $\square$ & $\square$ & $\square$ & $\square$ & $\square$ & 口 & $\square$ & $\square$ \\
\hline Ecosystems & $\square$ & $\square$ & $\square$ & $\square$ & $\square$ & $\square$ & $\square$ & $\square$ & $\square$ & $\square$ & $\square$ & $\square$ & $\square$ & $\square$ & $\square$ & $\square$ \\
\hline Renewable resources & $\square$ & 口 & $\square$ & $\square$ & $\square$ & $\square$ & $\square$ & 口 & $\square$ & 口 & $\square$ & $\square$ & $\square$ & $\square$ & $\square$ & $\square$ \\
\hline Norenewable resurces & $\square$ & $\square$ & $\square$ & $\square$ & $\square$ & $\square$ & $\square$ & $\square$ & $\square$ & $\square$ & $\square$ & $\square$ & $\square$ & $\square$ & $\square$ & $\square$ \\
\hline Identify renewable resources & $\square$ & 口 & $\square$ & $\square$ & $\square$ & $\square$ & 口 & 口 & $\square$ & 口 & $\square$ & $\square$ & 口 & $\square$ & 口 & $\square$ \\
\hline Identify nonrenewable resources & $\square$ & $\square$ & $\square$ & $\square$ & $\square$ & $\square$ & $\square$ & $\square$ & $\square$ & $\square$ & $\square$ & $\square$ & $\square$ & $\square$ & $\square$ & $\square$ \\
\hline Identify alternative energy sources & $\square$ & $\square$ & $\square$ & $\square$ & $\square$ & $\square$ & $\square$ & 口 & $\square$ & 口 & $\square$ & $\square$ & $\square$ & $\square$ & $\square$ & $\square$ \\
\hline $\begin{array}{l}\text { Identify healthy ecosystem } \\
\text { characteristics }\end{array}$ & $\square$ & 口 & $\square$ & $\square$ & $\square$ & $\square$ & $\square$ & 口 & $\square$ & $\square$ & $\square$ & $\square$ & $\square$ & $\square$ & $\square$ & $\square$ \\
\hline
\end{tabular}

Foundations of Plant Systems

\begin{tabular}{|c|c|c|c|c|c|c|c|c|c|c|c|c|c|c|c|c|}
\hline & \multicolumn{6}{|c|}{ Classroom } & \multicolumn{7}{|c|}{ Laboratory/Supervised Practice } & \multicolumn{3}{|c|}{ Other } \\
\hline & $\begin{array}{l}\text { Project } \\
\text { Based }\end{array}$ & Inquiry & Discussion & Demonstration & Lecture & $\begin{array}{l}\text { Textbooks/ } \\
\text { Handouts }\end{array}$ & Mechanies & Greenhouse & Meats & Biotechnology & Land & Forestry & Other & $\begin{array}{c}\text { Libraryl } \\
\text { computer } \\
\text { lab }\end{array}$ & $\underset{\substack{\text { Field } \\
\text { Trip }}}{\text { a }}$ & $\begin{array}{c}\text { Do } \\
\text { not } \\
\text { Teach }\end{array}$ \\
\hline Parts of a plant & $\square$ & $\square$ & $\square$ & $\square$ & $\square$ & $\square$ & $\square$ & $\square$ & $\square$ & $\square$ & $\square$ & $\square$ & $\square$ & $\square$ & $\square$ & $\square$ \\
\hline Functions of plant parts & $\square$ & 口 & $\square$ & $\square$ & ㅁ & $\square$ & 口 & 口 & $\square$ & 口 & $\square$ & $\square$ & 口 & 口 & $\square$ & $\square$ \\
\hline Basic soil science & $\square$ & $\square$ & $\square$ & $\square$ & $\square$ & $\square$ & $\square$ & $\square$ & $\square$ & $\square$ & $\square$ & $\square$ & $\square$ & $\square$ & $\square$ & $\square$ \\
\hline Basic plant nutrition & $\square$ & $\square$ & $\square$ & $\square$ & $\square$ & $\square$ & $\square$ & $\square$ & $\square$ & $\square$ & $\square$ & $\square$ & $\square$ & $\square$ & $\square$ & $\square$ \\
\hline $\begin{array}{l}\text { Plant physiology - photosynthesis, } \\
\text { reproduction, respiration, transpiration }\end{array}$ & $\square$ & $\square$ & $\square$ & $\square$ & $\square$ & $\square$ & $\square$ & $\square$ & $\square$ & $\square$ & $\square$ & $\square$ & $\square$ & $\square$ & $\square$ & $\square$ \\
\hline $\begin{array}{l}\text { Diagram a typical plant cell and } \\
\text { identify plant cell organelles and their } \\
\text { functions }\end{array}$ & $\square$ & 口 & $\square$ & $\square$ & $\square$ & $\square$ & $\square$ & 口 & $\square$ & $\square$ & $\square$ & $\square$ & 口 & $\square$ & 口 & 口 \\
\hline
\end{tabular}




\begin{tabular}{|c|c|c|c|c|c|c|c|c|c|c|c|c|c|c|c|c|}
\hline \multirow[t]{3}{*}{ 3/13/2019 } & \multicolumn{16}{|c|}{ Qualtrics Survey Software } \\
\hline & \multicolumn{6}{|c|}{ Classroom } & \multicolumn{7}{|c|}{ Laboratory/Supervised Practice } & \multicolumn{3}{|c|}{ Other } \\
\hline & $\begin{array}{l}\text { Project } \\
\text { Based }\end{array}$ & Inquiry & Discussion & Demonstration & Lecture & $\begin{array}{l}\text { Textbooksl } \\
\text { Handouts }\end{array}$ & Mechanics & Greenhouse & Meats & Biotechnology & Land & Forestry & Other & $\begin{array}{c}\text { Libranyl } \\
\text { computer } \\
\text { lab }\end{array}$ & $\begin{array}{c}\text { Field } \\
\text { Trip }\end{array}$ & $\begin{array}{c}\text { Do } \\
\text { not } \\
\text { Teach }\end{array}$ \\
\hline $\begin{array}{l}\text { Identify the components and functions } \\
\text { of plant roots }\end{array}$ & $\square$ & 口 & $\square$ & $\square$ & $\square$ & $\square$ & $\square$ & $\square$ & $\square$ & $\square$ & $\square$ & $\square$ & 口 & $\square$ & $\square$ & $\square$ \\
\hline $\begin{array}{l}\text { Identify the components and the } \\
\text { functions of plant stems }\end{array}$ & $\square$ & 口 & $\square$ & $\square$ & $\square$ & $\square$ & $\square$ & 口 & $\square$ & $\square$ & $\square$ & $\square$ & $\square$ & $\square$ & $\square$ & $\square$ \\
\hline $\begin{array}{l}\text { Identifit the components and the } \\
\text { functions of plant leaves }\end{array}$ & $\square$ & $\square$ & $\square$ & $\square$ & $\square$ & $\square$ & $\square$ & $\square$ & $\square$ & $\square$ & $\square$ & $\square$ & $\square$ & $\square$ & $\square$ & $\square$ \\
\hline $\begin{array}{l}\text { Identify the components and the } \\
\text { functions of plant flowers }\end{array}$ & $\square$ & 口 & $\square$ & $\square$ & $\square$ & $\square$ & 口 & 口 & $\square$ & 口 & $\square$ & $\square$ & $\square$ & $\square$ & $\square$ & 口 \\
\hline $\begin{array}{l}\text { Interpret soil results to determine } \\
\text { fertilizer application needs }\end{array}$ & $\square$ & 口 & $\square$ & $\square$ & 口 & $\square$ & $\square$ & 口 & $\square$ & 口 & $\square$ & $\square$ & $\square$ & 口 & 口 & $\square$ \\
\hline Conduct soil sampling and testing & $\square$ & $\square$ & $\square$ & $\square$ & $\square$ & $\square$ & $\square$ & $\square$ & $\square$ & $\square$ & $\square$ & $\square$ & $\square$ & $\square$ & 口 & $\square$ \\
\hline $\begin{array}{l}\text { Identify agriculturally important plants } \\
\text { by common names }\end{array}$ & $\square$ & ם & $\square$ & $\square$ & $\square$ & $\square$ & 口 & 口 & $\square$ & 口 & $\square$ & $\square$ & 口 & 口 & 口 & 口 \\
\hline
\end{tabular}

Foundations of Power. Structural and Technical Systems

\begin{tabular}{|c|c|c|c|c|c|c|c|c|c|c|c|c|c|c|c|c|}
\hline & \multicolumn{6}{|c|}{ Classroom } & \multicolumn{7}{|c|}{ Laboratory/Supervised Practice } & \multicolumn{3}{|c|}{ Other } \\
\hline & $\begin{array}{l}\text { Project } \\
\text { Based }\end{array}$ & Inquiry & Discussion & Demonstration & Lecture & $\begin{array}{l}\text { Textbooks/ } \\
\text { Handouts }\end{array}$ & Mechanics & Greenhouse & Meats & Biotechnology & Land & Forestry & Other & $\begin{array}{l}\text { Libraryl } \\
\text { computer } \\
\text { lab }\end{array}$ & $\begin{array}{l}\text { Field } \\
\text { Trip }\end{array}$ & $\begin{array}{c}\text { Do } \\
\text { not } \\
\text { Teach }\end{array}$ \\
\hline $\begin{array}{l}\text { Units of weight, volume, and } \\
\text { temperature }\end{array}$ & $\square$ & 口 & $\square$ & $\square$ & $\square$ & $\square$ & $\square$ & $\square$ & $\square$ & $\square$ & $\square$ & $\square$ & $\square$ & $\square$ & $\square$ & $\square$ \\
\hline $\begin{array}{l}\text { Basic math practices used in power, } \\
\text { structural and technical systems }\end{array}$ & $\square$ & $\square$ & $\square$ & $\square$ & $\square$ & $\square$ & $\square$ & $\square$ & $\square$ & $\square$ & $\square$ & $\square$ & $\square$ & $\square$ & $\square$ & $\square$ \\
\hline $\begin{array}{l}\text { The basic hand tools and their proper } \\
\text { uses in an agricultural setting }\end{array}$ & $\square$ & $\square$ & $\square$ & $\square$ & $\square$ & $\square$ & $\square$ & 口 & $\square$ & $\square$ & $\square$ & $\square$ & $\square$ & 口 & $\square$ & 口 \\
\hline $\begin{array}{l}\text { Add, subract, multiply, and divide } \\
\text { whole numbers, with and without a } \\
\text { calculatoror }\end{array}$ & $\square$ & $\square$ & $\square$ & $\square$ & $\square$ & $\square$ & $\square$ & $\square$ & $\square$ & $\square$ & $\square$ & $\square$ & $\square$ & $\square$ & $\square$ & $\square$ \\
\hline $\begin{array}{l}\text { Use a nuler, a metric nuler, and a } \\
\text { measuring tape to measure }\end{array}$ & $\square$ & $\square$ & $\square$ & $\square$ & $\square$ & $\square$ & $\square$ & $\square$ & $\square$ & $\square$ & $\square$ & $\square$ & $\square$ & $\square$ & $\square$ & $\square$ \\
\hline $\begin{array}{l}\text { Add, subtract, multiply, and divide } \\
\text { fractions }\end{array}$ & $\square$ & $\square$ & $\square$ & $\square$ & $\square$ & $\square$ & $\square$ & 口 & $\square$ & $\square$ & $\square$ & $\square$ & $\square$ & $\square$ & $\square$ & $\square$ \\
\hline $\begin{array}{l}\text { Add, subtract, multiply, and divide } \\
\text { decimals, with and wthout a } \\
\text { calculatator }\end{array}$ & $\square$ & $\square$ & $\square$ & $\square$ & $\square$ & $\square$ & $\square$ & $\square$ & $\square$ & $\square$ & $\square$ & $\square$ & $\square$ & $\square$ & $\square$ & 口 \\
\hline $\begin{array}{l}\text { Convert decimals to percentages and } \\
\text { percentages to decimals }\end{array}$ & $\square$ & $\square$ & $\square$ & $\square$ & $\square$ & $\square$ & $\square$ & $\square$ & $\square$ & $\square$ & $\square$ & $\square$ & $\square$ & $\square$ & $\square$ & $\square$ \\
\hline
\end{tabular}




\begin{tabular}{|c|c|c|c|c|c|c|c|c|c|c|c|c|c|c|c|c|}
\hline \multirow[t]{3}{*}{$3 / 13 / 2019$} & \multicolumn{16}{|c|}{ Qualtrics Survey Software } \\
\hline & \multicolumn{6}{|c|}{ Classroom } & \multicolumn{7}{|c|}{ Laboratory/Supenvised Practice } & \multicolumn{3}{|c|}{ Other } \\
\hline & $\begin{array}{l}\begin{array}{l}\text { Project } \\
\text { Based }\end{array} \\
\text { a }\end{array}$ & Inquiry & Discussion & Demonstration & Lecture & $\begin{array}{l}\text { Textbooks/ } \\
\text { Handouts }\end{array}$ & Mechanics & Greenhouse & Meats & Biotechnology & Land & Forestry & Other & $\begin{array}{c}\text { Libranyl } \\
\text { computer } \\
\text { lab }\end{array}$ & $\begin{array}{l}\text { Field } \\
\text { Trip }\end{array}$ & $\begin{array}{c}\text { Do } \\
\text { not } \\
\text { Teach }\end{array}$ \\
\hline $\begin{array}{l}\text { onvert fractions to decimal and } \\
\text { decimals to fractions }\end{array}$ & $\square$ & $\square$ & $\square$ & $\square$ & $\square$ & $\square$ & $\square$ & $\square$ & $\square$ & $\square$ & $\square$ & $\square$ & $\square$ & $\square$ & $\square$ & $\square$ \\
\hline Property and safely use hand tods & 口 & 口 & 口 & 口 & $\square$ & 口 & 口 & 口 & $\square$ & 口 & 口 & 口 & 口 & 口 & 口 & 口 \\
\hline Construct a project using hand tools & 口 & 口 & ㅁ & 口 & 口 & $\square$ & 口 & ם & $\square$ & 口 & $\square$ & $\square$ & $\square$ & $\square$ & 口 & 口 \\
\hline
\end{tabular}

Leadership Development through FFA

\begin{tabular}{|c|c|c|c|c|c|c|c|c|c|c|c|c|c|c|c|c|}
\hline & \multicolumn{6}{|c|}{ Classroom } & \multicolumn{7}{|c|}{ Laboratory/Supervised Practice } & \multicolumn{3}{|c|}{ Other } \\
\hline & $\begin{array}{l}\text { Project } \\
\text { Based }\end{array}$ & Inquiry & Discussion & Demonstration & Lecture & $\begin{array}{l}\text { Textbooks/ } \\
\text { Handouts }\end{array}$ & Mechanics & Greenhouse & Meats & Biotechnology & Land & Forestry & Other & $\begin{array}{l}\text { Libraryl } \\
\text { computer } \\
\text { lab }\end{array}$ & $\begin{array}{l}\text { Field } \\
\text { Trip }\end{array}$ & $\begin{array}{c}\text { Do } \\
\text { not } \\
\text { Teach }\end{array}$ \\
\hline $\begin{array}{l}\text { Students will demonstrate knowledge } \\
\text { of FFA history, Code of Ethics and } \\
\text { Official Dress }\end{array}$ & $\square$ & 口 & $\square$ & 口 & $\square$ & 口 & 口 & $\square$ & $\square$ & 口 & $\square$ & $\square$ & 口 & $\square$ & 口 & 口 \\
\hline Recite the FFA Creed & $\square$ & $\square$ & $\square$ & $\square$ & $\square$ & $\square$ & $\square$ & $\square$ & $\square$ & $\square$ & $\square$ & $\square$ & $\square$ & $\square$ & $\square$ & $\square$ \\
\hline Recite the FFA motto & $\square$ & $\square$ & $\square$ & $\square$ & $\square$ & $\square$ & $\square$ & $\square$ & $\square$ & $\square$ & $\square$ & $\square$ & $\square$ & $\square$ & $\square$ & $\square$ \\
\hline $\begin{array}{l}\text { Research the important dates and } \\
\text { events in the history of } F A \text { and } \\
\text { Agricultural Education }\end{array}$ & $\square$ & $\square$ & $\square$ & $\square$ & $\square$ & $\square$ & $\square$ & $\square$ & $\square$ & $\square$ & $\square$ & $\square$ & $\square$ & $\square$ & $\square$ & $\square$ \\
\hline
\end{tabular}

Thank you for taking the time to share the methods you use to deliver the Introduction to Agriculture, Food and Natural Resources course. Please proceed to the "demographic" section of the survey.

This survey deals with the methods teachers use to teach the Content Skill Sets associated with the Introduction to Agriculture, Food and Natural Resources course. Since you do not personally teach the course please proceed to the "demographic" section of the survey.

\section{Demographics}

What is your gender?

Male

Female

Using the categories listed below, please indicate the number of years you have been teaching?

$0-4$ years

https://wvu.ca1.qualtrics.com/NRQualtricsControlPanel/Ajax.php?action=GetSurveyPrintPreview 
$5-10$ years
11.15 years

$16-20$ years

21.25 years

26.30 years

over 30 vears

Using the categories listed below, please indicate your age?

$20-29$ years

30 - 39 years

$40-49$ years

50 - 59 years

60 - 69 years

70 years or older

What is the highest degree you have earned?

Bachelor of Science/Arts (BS/BA)

Master of Sciencel/Arts (MS/MA)

Doctor of Education (EdD)

Dootor of Philosophy (PhD)

Please provide your name.

This information will be used only to follow-up non-responders and will be removed from the data before it is analyzed. In other words this will prevent you from receiving multiple follow-up email messages after you respond to the survey

Thank you for your response.

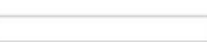


APPENDIX E

\section{Raw Data}


Table Appendix 5

Percent of Respondents Using Particular Delivery Method for Each Content Skill Sets

\begin{tabular}{|c|c|c|}
\hline Method & Content Skill Set & Mean \\
\hline \multirow[t]{19}{*}{ Project Based } & $\begin{array}{l}\text { Add, subtract, multiply, and divide decimals, with and } \\
\text { without a calculator }\end{array}$ & 11.54 \\
\hline & Add, subtract, multiply, and divide fractions & 11.54 \\
\hline & $\begin{array}{l}\text { Add, subtract, multiply, and divide whole numbers, } \\
\text { with and without a calculator }\end{array}$ & 19.23 \\
\hline & Agricultural biotechnology & 19.23 \\
\hline & Animal cells & 19.23 \\
\hline & Animal health disorders & 38.46 \\
\hline & Animal welfare and animal rights & 23.08 \\
\hline & Applications of biotechnology in agriculture & 15.38 \\
\hline & Basic anatomy of animals & 23.08 \\
\hline & $\begin{array}{l}\text { Basic finance - personal inventory, net worth, income, } \\
\text { expense }\end{array}$ & 46.15 \\
\hline & $\begin{array}{l}\text { Basic math practices used in power, structural and } \\
\text { technical systems }\end{array}$ & 19.23 \\
\hline & Basic plant nutrition & 30.77 \\
\hline & Basic soil science & 34.62 \\
\hline & Bio-security in the animal industry & 15.38 \\
\hline & Breeds of livestock & 34.62 \\
\hline & Common and scientific names of major animal species & 15.38 \\
\hline & Common types of feedstuffs & 34.62 \\
\hline & $\begin{array}{l}\text { Common weights and measures in the food products } \\
\text { and processing industry }\end{array}$ & 7.69 \\
\hline & Compare and contrast various food labels & 15.38 \\
\hline
\end{tabular}


Table Appendix 5

Percent of Respondents Using Particular Delivery Method for Each Content Skill Sets

\begin{tabular}{|c|c|c|}
\hline Method & Content Skill Set & Mean \\
\hline & Conduct a food preservation experiment. & 26.92 \\
\hline & Conduct soil sampling and testing & 38.46 \\
\hline & Construct a project using hand tools & 26.92 \\
\hline & $\begin{array}{l}\text { Convert decimals to percentages and percentages to } \\
\text { decimals }\end{array}$ & 11.54 \\
\hline & Convert fractions to decimal and decimals to fractions & 7.69 \\
\hline & Create a plan for their own agricultural enterprises & 84.62 \\
\hline & Create an advertisement for an agricultural product & 73.08 \\
\hline & $\begin{array}{l}\text { Debate the issues associated with animal welfare and } \\
\text { animal rights }\end{array}$ & 23.08 \\
\hline & Debate the issues associated with biotechnology & 11.54 \\
\hline & $\begin{array}{l}\text { Diagram a typical animal cell and identify the } \\
\text { organelles }\end{array}$ & 30.77 \\
\hline & $\begin{array}{l}\text { Diagram a typical plant cell and identify plant cell } \\
\text { organelles and their functions }\end{array}$ & 15.38 \\
\hline & Ecosystems & 11.54 \\
\hline & Effects of animal agriculture on the environment & 30.77 \\
\hline & $\begin{array}{l}\text { Facilities needed to housed and produce animal species } \\
\text { safely and efficiently }\end{array}$ & 34.62 \\
\hline & $\begin{array}{l}\text { Foods derived from meat, egg, poultry, fish and dairy } \\
\text { products }\end{array}$ & 23.08 \\
\hline & Functions of plant parts & 23.08 \\
\hline & $\begin{array}{l}\text { Identify agriculturally important plants by common } \\
\text { names }\end{array}$ & 34.62 \\
\hline & Identify alternative energy sources & 15.38 \\
\hline
\end{tabular}


Table Appendix 5

Percent of Respondents Using Particular Delivery Method for Each Content Skill Sets

\begin{tabular}{|c|c|c|}
\hline Method & Content Skill Set & Mean \\
\hline & Identify healthy ecosystem characteristics & 7.69 \\
\hline & Identify nonrenewable resources & 11.54 \\
\hline & Identify renewable resources & 15.38 \\
\hline & Identify the components and functions of plant roots & 23.08 \\
\hline & $\begin{array}{l}\text { Identify the components and the functions of plant } \\
\text { flowers }\end{array}$ & 19.23 \\
\hline & $\begin{array}{l}\text { Identify the components and the functions of plant } \\
\text { leaves }\end{array}$ & 23.08 \\
\hline & $\begin{array}{l}\text { Identify the components and the functions of plant } \\
\text { stems }\end{array}$ & 23.08 \\
\hline & $\begin{array}{l}\text { Interpret soil results to determine fertilizer application } \\
\text { needs }\end{array}$ & 26.92 \\
\hline & Livestock terminology (steer, heifer, barrow, gilt, etc.) & 26.92 \\
\hline & Methods of food preservations & 30.77 \\
\hline & $\begin{array}{l}\text { Methods of marketing agricultural commodities, } \\
\text { products and services in domestic and international } \\
\text { markets }\end{array}$ & 57.69 \\
\hline & Natural resources & 23.08 \\
\hline & Nonrenewable resources & 19.23 \\
\hline & Parts of a plant & 26.92 \\
\hline & Perform a basic health exam on a live animal & 19.23 \\
\hline & $\begin{array}{l}\text { Plant physiology - photosynthesis, reproduction, } \\
\text { respiration, transpiration }\end{array}$ & 19.23 \\
\hline & Practice administering injections & 34.62 \\
\hline
\end{tabular}


Table Appendix 5

Percent of Respondents Using Particular Delivery Method for Each Content Skill Sets

\begin{tabular}{|c|c|c|}
\hline Method & Content Skill Set & Mean \\
\hline & $\begin{array}{l}\text { Produce a food product (cheese, sausage, sauerkraut, } \\
\text { etc.) }\end{array}$ & 38.46 \\
\hline & Products derived from fruits and vegetables & 19.23 \\
\hline & Products derived from grains, legumes and oilseeds & 15.38 \\
\hline & Properly and safely used hand tools & 23.08 \\
\hline & Quality and yield grades of food products & 19.23 \\
\hline & Recite the FFA Creed & 46.15 \\
\hline & Recite the FFA motto & 46.15 \\
\hline & Renewable resources & 15.38 \\
\hline & $\begin{array}{l}\text { Research current agricultural products impacted by } \\
\text { biotechnology practices }\end{array}$ & 23.08 \\
\hline & $\begin{array}{l}\text { Research local supply and demand of agricultural } \\
\text { products }\end{array}$ & 46.15 \\
\hline & $\begin{array}{l}\text { Research the important dates and events in the history } \\
\text { of FFA and Agricultural Education }\end{array}$ & 38.46 \\
\hline & Return on investment & 34.62 \\
\hline & $\begin{array}{l}\text { Students will demonstrate knowledge of FFA history, } \\
\text { Code of Ethics and Official Dress }\end{array}$ & 34.62 \\
\hline & Supervised Agricultural Experience Program (SAE) & 76.92 \\
\hline & $\begin{array}{l}\text { The basic hand tools and their proper used in an } \\
\text { agricultural setting }\end{array}$ & 19.23 \\
\hline & The Four Ps (product, place, price and promotion) & 46.15 \\
\hline & The history of agriculture innovation & 11.54 \\
\hline & The history of the animal processing industry & 3.85 \\
\hline
\end{tabular}


Table Appendix 5

Percent of Respondents Using Particular Delivery Method for Each Content Skill Sets

\begin{tabular}{|c|c|c|}
\hline Method & Content Skill Set & Mean \\
\hline & The importance of food labeling to the consumer & .00 \\
\hline & $\begin{array}{l}\text { The major agriculture inventions and their impact on } \\
\text { the industry. }\end{array}$ & 11.54 \\
\hline & $\begin{array}{l}\text { The origin, significance, distribution and domestication } \\
\text { of animal systems }\end{array}$ & 34.62 \\
\hline & Types of agribusiness ownership & 65.38 \\
\hline & Units of weight, volume, and temperature & 15.38 \\
\hline & $\begin{array}{l}\text { Used a ruler, a metric ruler, and a measuring tape to } \\
\text { measure }\end{array}$ & 23.08 \\
\hline & Used agricultural related technology and equipment & 23.08 \\
\hline \multirow[t]{11}{*}{ Inquiry } & $\begin{array}{l}\text { Add, subtract, multiply, and divide decimals, with and } \\
\text { without a calculator }\end{array}$ & 11.54 \\
\hline & Add, subtract, multiply, and divide fractions & 11.54 \\
\hline & $\begin{array}{l}\text { Add, subtract, multiply, and divide whole numbers, } \\
\text { with and without a calculator }\end{array}$ & 11.54 \\
\hline & Agricultural biotechnology & 19.23 \\
\hline & Animal cells & 23.08 \\
\hline & Animal health disorders & 26.92 \\
\hline & Animal welfare and animal rights & 23.08 \\
\hline & Applications of biotechnology in agriculture & 15.38 \\
\hline & Basic anatomy of animals & 23.08 \\
\hline & $\begin{array}{l}\text { Basic finance - personal inventory, net worth, income, } \\
\text { expense }\end{array}$ & 26.92 \\
\hline & $\begin{array}{l}\text { Basic math practices used in power, structural and } \\
\text { technical systems }\end{array}$ & 7.69 \\
\hline
\end{tabular}


Table Appendix 5

Percent of Respondents Using Particular Delivery Method for Each Content Skill Sets

\begin{tabular}{|c|c|c|}
\hline Method & Content Skill Set & Mean \\
\hline & Basic plant nutrition & 15.38 \\
\hline & Basic soil science & 11.54 \\
\hline & Bio-security in the animal industry & 19.23 \\
\hline & Breeds of livestock & 23.08 \\
\hline & Common and scientific names of major animal species & 19.23 \\
\hline & Common types of feedstuffs & 26.92 \\
\hline & $\begin{array}{l}\text { Common weights and measures in the food products } \\
\text { and processing industry }\end{array}$ & 7.69 \\
\hline & Compare and contrast various food labels & 15.38 \\
\hline & Conduct a food preservation experiment. & 3.85 \\
\hline & Conduct soil sampling and testing & 11.54 \\
\hline & Construct a project using hand tools & 15.38 \\
\hline & $\begin{array}{l}\text { Convert decimals to percentages and percentages to } \\
\text { decimals }\end{array}$ & 11.54 \\
\hline & Convert fractions to decimal and decimals to fractions & 11.54 \\
\hline & Create a plan for their own agricultural enterprises & 30.77 \\
\hline & Create an advertisement for an agricultural product & 19.23 \\
\hline & $\begin{array}{l}\text { Debate the issues associated with animal welfare and } \\
\text { animal rights }\end{array}$ & 19.23 \\
\hline & Debate the issues associated with biotechnology & 7.69 \\
\hline & $\begin{array}{l}\text { Diagram a typical animal cell and identify the } \\
\text { organelles }\end{array}$ & 19.23 \\
\hline & $\begin{array}{l}\text { Diagram a typical plant cell and identify plant cell } \\
\text { organelles and their functions }\end{array}$ & 11.54 \\
\hline
\end{tabular}


Table Appendix 5

Percent of Respondents Using Particular Delivery Method for Each Content Skill Sets

\begin{tabular}{|c|c|c|}
\hline Method & Content Skill Set & Mean \\
\hline & Ecosystems & 15.38 \\
\hline & Effects of animal agriculture on the environment & 19.23 \\
\hline & $\begin{array}{l}\text { Facilities needed to housed and produce animal species } \\
\text { safely and efficiently }\end{array}$ & 19.23 \\
\hline & $\begin{array}{l}\text { Foods derived from meat, egg, poultry, fish and dairy } \\
\text { products }\end{array}$ & 15.38 \\
\hline & Functions of plant parts & 7.69 \\
\hline & $\begin{array}{l}\text { Identify agriculturally important plants by common } \\
\text { names }\end{array}$ & 11.54 \\
\hline & Identify alternative energy sources & 19.23 \\
\hline & Identify healthy ecosystem characteristics & 15.38 \\
\hline & Identify nonrenewable resources & 15.38 \\
\hline & Identify renewable resources & 19.23 \\
\hline & Identify the components and functions of plant roots & 11.54 \\
\hline & $\begin{array}{l}\text { Identify the components and the functions of plant } \\
\text { flowers }\end{array}$ & 7.69 \\
\hline & $\begin{array}{l}\text { Identify the components and the functions of plant } \\
\text { leaves }\end{array}$ & 11.54 \\
\hline & $\begin{array}{l}\text { Identify the components and the functions of plant } \\
\text { stems }\end{array}$ & 7.69 \\
\hline & $\begin{array}{l}\text { Interpret soil results to determine fertilizer application } \\
\text { needs }\end{array}$ & 15.38 \\
\hline & Livestock terminology (steer, heifer, barrow, gilt, etc.) & 15.38 \\
\hline & Methods of food preservations & 11.54 \\
\hline
\end{tabular}


Table Appendix 5

Percent of Respondents Using Particular Delivery Method for Each Content Skill Sets

\begin{tabular}{|c|c|c|}
\hline Method & Content Skill Set & Mean \\
\hline & $\begin{array}{l}\text { Methods of marketing agricultural commodities, } \\
\text { products and services in domestic and international } \\
\text { markets }\end{array}$ & 23.08 \\
\hline & Natural resources & 15.38 \\
\hline & Nonrenewable resources & 19.23 \\
\hline & Parts of a plant & 11.54 \\
\hline & Perform a basic health exam on a live animal & 7.69 \\
\hline & $\begin{array}{l}\text { Plant physiology - photosynthesis, reproduction, } \\
\text { respiration, transpiration }\end{array}$ & 15.38 \\
\hline & Practice administering injections & 11.54 \\
\hline & $\begin{array}{l}\text { Produce a food product (cheese, sausage, sauerkraut, } \\
\text { etc.) }\end{array}$ & 3.85 \\
\hline & Products derived from fruits and vegetables & 15.38 \\
\hline & Products derived from grains, legumes and oilseeds & 15.38 \\
\hline & Properly and safely used hand tools & 15.38 \\
\hline & Quality and yield grades of food products & 11.54 \\
\hline & Recite the FFA Creed & 7.69 \\
\hline & Recite the FFA motto & 7.69 \\
\hline & Renewable resources & 15.38 \\
\hline & $\begin{array}{l}\text { Research current agricultural products impacted by } \\
\text { biotechnology practices }\end{array}$ & 15.38 \\
\hline & $\begin{array}{l}\text { Research local supply and demand of agricultural } \\
\text { products }\end{array}$ & 26.92 \\
\hline & $\begin{array}{l}\text { Research the important dates and events in the history } \\
\text { of FFA and Agricultural Education }\end{array}$ & 19.23 \\
\hline
\end{tabular}


Table Appendix 5

Percent of Respondents Using Particular Delivery Method for Each Content Skill Sets

\begin{tabular}{|c|c|c|}
\hline Method & Content Skill Set & Mean \\
\hline & Return on investment & 19.23 \\
\hline & $\begin{array}{l}\text { Students will demonstrate knowledge of FFA history, } \\
\text { Code of Ethics and Official Dress }\end{array}$ & 3.85 \\
\hline & Supervised Agricultural Experience Program (SAE) & 38.46 \\
\hline & $\begin{array}{l}\text { The basic hand tools and their proper used in an } \\
\text { agricultural setting }\end{array}$ & 11.54 \\
\hline & The Four Ps (product, place, price and promotion) & 23.08 \\
\hline & The history of agriculture innovation & 15.38 \\
\hline & The history of the animal processing industry & 3.85 \\
\hline & The importance of food labeling to the consumer & 15.38 \\
\hline & $\begin{array}{l}\text { The major agriculture inventions and their impact on } \\
\text { the industry. }\end{array}$ & 19.23 \\
\hline & $\begin{array}{l}\text { The origin, significance, distribution and domestication } \\
\text { of animal systems }\end{array}$ & 11.54 \\
\hline & Types of agribusiness ownership & 26.92 \\
\hline & Units of weight, volume, and temperature & 7.69 \\
\hline & $\begin{array}{l}\text { Used a ruler, a metric ruler, and a measuring tape to } \\
\text { measure }\end{array}$ & 11.54 \\
\hline & Used agricultural related technology and equipment & 7.69 \\
\hline \multirow[t]{4}{*}{ Discussion } & $\begin{array}{l}\text { Add, subtract, multiply, and divide decimals, with and } \\
\text { without a calculator }\end{array}$ & 19.23 \\
\hline & Add, subtract, multiply, and divide fractions & 19.23 \\
\hline & $\begin{array}{l}\text { Add, subtract, multiply, and divide whole numbers, } \\
\text { with and without a calculator }\end{array}$ & 19.23 \\
\hline & Agricultural biotechnology & 30.77 \\
\hline
\end{tabular}


Table Appendix 5

Percent of Respondents Using Particular Delivery Method for Each Content Skill Sets

\begin{tabular}{|c|c|c|}
\hline Method & Content Skill Set & Mean \\
\hline & Animal cells & 15.38 \\
\hline & Animal health disorders & 30.77 \\
\hline & Animal welfare and animal rights & 50.00 \\
\hline & Applications of biotechnology in agriculture & 42.31 \\
\hline & Basic anatomy of animals & 30.77 \\
\hline & $\begin{array}{l}\text { Basic finance - personal inventory, net worth, income, } \\
\text { expense }\end{array}$ & 50.00 \\
\hline & $\begin{array}{l}\text { Basic math practices used in power, structural and } \\
\text { technical systems }\end{array}$ & 15.38 \\
\hline & Basic plant nutrition & 26.92 \\
\hline & Basic soil science & 23.08 \\
\hline & Bio-security in the animal industry & 30.77 \\
\hline & Breeds of livestock & 38.46 \\
\hline & Common and scientific names of major animal species & 23.08 \\
\hline & Common types of feedstuffs & 26.92 \\
\hline & $\begin{array}{l}\text { Common weights and measures in the food products } \\
\text { and processing industry }\end{array}$ & 30.77 \\
\hline & Compare and contrast various food labels & 26.92 \\
\hline & Conduct a food preservation experiment. & 3.85 \\
\hline & Conduct soil sampling and testing & 19.23 \\
\hline & Construct a project using hand tools & 23.08 \\
\hline & $\begin{array}{l}\text { Convert decimals to percentages and percentages to } \\
\text { decimals }\end{array}$ & 19.23 \\
\hline
\end{tabular}


Table Appendix 5

Percent of Respondents Using Particular Delivery Method for Each Content Skill Sets

\begin{tabular}{|c|c|c|}
\hline Method & Content Skill Set & Mean \\
\hline & Convert fractions to decimal and decimals to fractions & 15.38 \\
\hline & Create a plan for their own agricultural enterprises & 42.31 \\
\hline & Create an advertisement for an agricultural product & 30.77 \\
\hline & $\begin{array}{l}\text { Debate the issues associated with animal welfare and } \\
\text { animal rights }\end{array}$ & 50.00 \\
\hline & Debate the issues associated with biotechnology & 50.00 \\
\hline & $\begin{array}{l}\text { Diagram a typical animal cell and identify the } \\
\text { organelles }\end{array}$ & 15.38 \\
\hline & $\begin{array}{l}\text { Diagram a typical plant cell and identify plant cell } \\
\text { organelles and their functions }\end{array}$ & 26.92 \\
\hline & Ecosystems & 38.46 \\
\hline & Effects of animal agriculture on the environment & 34.62 \\
\hline & $\begin{array}{l}\text { Facilities needed to housed and produce animal species } \\
\text { safely and efficiently }\end{array}$ & 23.08 \\
\hline & $\begin{array}{l}\text { Foods derived from meat, egg, poultry, fish and dairy } \\
\text { products }\end{array}$ & 34.62 \\
\hline & Functions of plant parts & 30.77 \\
\hline & $\begin{array}{l}\text { Identify agriculturally important plants by common } \\
\text { names }\end{array}$ & 30.77 \\
\hline & Identify alternative energy sources & 42.31 \\
\hline & Identify healthy ecosystem characteristics & 38.46 \\
\hline & Identify nonrenewable resources & 38.46 \\
\hline & Identify renewable resources & 42.31 \\
\hline & Identify the components and functions of plant roots & 30.77 \\
\hline
\end{tabular}


Table Appendix 5

Percent of Respondents Using Particular Delivery Method for Each Content Skill Sets

\begin{tabular}{|c|c|c|}
\hline Method & Content Skill Set & Mean \\
\hline & $\begin{array}{l}\text { Identify the components and the functions of plant } \\
\text { flowers }\end{array}$ & 30.77 \\
\hline & $\begin{array}{l}\text { Identify the components and the functions of plant } \\
\text { leaves }\end{array}$ & 30.77 \\
\hline & $\begin{array}{l}\text { Identify the components and the functions of plant } \\
\text { stems }\end{array}$ & 30.77 \\
\hline & $\begin{array}{l}\text { Interpret soil results to determine fertilizer application } \\
\text { needs }\end{array}$ & 26.92 \\
\hline & Livestock terminology (steer, heifer, barrow, gilt, etc.) & 38.46 \\
\hline & Methods of food preservations & 19.23 \\
\hline & $\begin{array}{l}\text { Methods of marketing agricultural commodities, } \\
\text { products and services in domestic and international } \\
\text { markets }\end{array}$ & 42.31 \\
\hline & Natural resources & 38.46 \\
\hline & Nonrenewable resources & 38.46 \\
\hline & Parts of a plant & 19.23 \\
\hline & Perform a basic health exam on a live animal & 11.54 \\
\hline & $\begin{array}{l}\text { Plant physiology - photosynthesis, reproduction, } \\
\text { respiration, transpiration }\end{array}$ & 26.92 \\
\hline & Practice administering injections & 11.54 \\
\hline & $\begin{array}{l}\text { Produce a food product (cheese, sausage, sauerkraut, } \\
\text { etc.) }\end{array}$ & 11.54 \\
\hline & Products derived from fruits and vegetables & 38.46 \\
\hline & Products derived from grains, legumes and oilseeds & 30.77 \\
\hline & Properly and safely used hand tools & 34.62 \\
\hline
\end{tabular}


Table Appendix 5

Percent of Respondents Using Particular Delivery Method for Each Content Skill Sets

\begin{tabular}{|c|c|c|}
\hline Method & Content Skill Set & Mean \\
\hline & Quality and yield grades of food products & 26.92 \\
\hline & Recite the FFA Creed & 30.77 \\
\hline & Recite the FFA motto & 26.92 \\
\hline & Renewable resources & 38.46 \\
\hline & $\begin{array}{l}\text { Research current agricultural products impacted by } \\
\text { biotechnology practices }\end{array}$ & 19.23 \\
\hline & $\begin{array}{l}\text { Research local supply and demand of agricultural } \\
\text { products }\end{array}$ & 34.62 \\
\hline & $\begin{array}{l}\text { Research the important dates and events in the history } \\
\text { of FFA and Agricultural Education }\end{array}$ & 30.77 \\
\hline & Return on investment & 38.46 \\
\hline & $\begin{array}{l}\text { Students will demonstrate knowledge of FFA history, } \\
\text { Code of Ethics and Official Dress }\end{array}$ & 38.46 \\
\hline & Supervised Agricultural Experience Program (SAE) & 53.85 \\
\hline & $\begin{array}{l}\text { The basic hand tools and their proper used in an } \\
\text { agricultural setting }\end{array}$ & 23.08 \\
\hline & The Four Ps (product, place, price and promotion) & 42.31 \\
\hline & The history of agriculture innovation & 34.62 \\
\hline & The history of the animal processing industry & 15.38 \\
\hline & The importance of food labeling to the consumer & 38.46 \\
\hline & $\begin{array}{l}\text { The major agriculture inventions and their impact on } \\
\text { the industry. }\end{array}$ & 42.31 \\
\hline & $\begin{array}{l}\text { The origin, significance, distribution and domestication } \\
\text { of animal systems }\end{array}$ & 34.62 \\
\hline & Types of agribusiness ownership & 57.69 \\
\hline
\end{tabular}


Table Appendix 5

Percent of Respondents Using Particular Delivery Method for Each Content Skill Sets

\begin{tabular}{|c|c|c|}
\hline Method & Content Skill Set & Mean \\
\hline & Units of weight, volume, and temperature & 19.23 \\
\hline & $\begin{array}{l}\text { Used a ruler, a metric ruler, and a measuring tape to } \\
\text { measure }\end{array}$ & 23.08 \\
\hline & Used agricultural related technology and equipment & 26.92 \\
\hline \multirow[t]{16}{*}{ Demonstration } & $\begin{array}{l}\text { Add, subtract, multiply, and divide decimals, with and } \\
\text { without a calculator }\end{array}$ & 19.23 \\
\hline & Add, subtract, multiply, and divide fractions & 15.38 \\
\hline & $\begin{array}{l}\text { Add, subtract, multiply, and divide whole numbers, } \\
\text { with and without a calculator }\end{array}$ & 19.23 \\
\hline & Agricultural biotechnology & 3.85 \\
\hline & Animal cells & 7.69 \\
\hline & Animal health disorders & 3.85 \\
\hline & Animal welfare and animal rights & 7.69 \\
\hline & Applications of biotechnology in agriculture & 3.85 \\
\hline & Basic anatomy of animals & 19.23 \\
\hline & $\begin{array}{l}\text { Basic finance - personal inventory, net worth, income, } \\
\text { expense }\end{array}$ & 23.08 \\
\hline & $\begin{array}{l}\text { Basic math practices used in power, structural and } \\
\text { technical systems }\end{array}$ & 26.92 \\
\hline & Basic plant nutrition & 11.54 \\
\hline & Basic soil science & 23.08 \\
\hline & Bio-security in the animal industry & 7.69 \\
\hline & Breeds of livestock & 3.85 \\
\hline & Common and scientific names of major animal species & .00 \\
\hline
\end{tabular}


Table Appendix 5

Percent of Respondents Using Particular Delivery Method for Each Content Skill Sets

\begin{tabular}{|c|c|c|}
\hline Method & Content Skill Set & Mean \\
\hline & Common types of feedstuffs & 23.08 \\
\hline & $\begin{array}{l}\text { Common weights and measures in the food products } \\
\text { and processing industry }\end{array}$ & 15.38 \\
\hline & Compare and contrast various food labels & 15.38 \\
\hline & Conduct a food preservation experiment. & 7.69 \\
\hline & Conduct soil sampling and testing & 15.38 \\
\hline & Construct a project using hand tools & 26.92 \\
\hline & $\begin{array}{l}\text { Convert decimals to percentages and percentages to } \\
\text { decimals }\end{array}$ & 19.23 \\
\hline & Convert fractions to decimal and decimals to fractions & 15.38 \\
\hline & Create a plan for their own agricultural enterprises & 7.69 \\
\hline & Create an advertisement for an agricultural product & 15.38 \\
\hline & $\begin{array}{l}\text { Debate the issues associated with animal welfare and } \\
\text { animal rights }\end{array}$ & 7.69 \\
\hline & Debate the issues associated with biotechnology & 7.69 \\
\hline & $\begin{array}{l}\text { Diagram a typical animal cell and identify the } \\
\text { organelles }\end{array}$ & 3.85 \\
\hline & $\begin{array}{l}\text { Diagram a typical plant cell and identify plant cell } \\
\text { organelles and their functions }\end{array}$ & .00 \\
\hline & Ecosystems & .00 \\
\hline & Effects of animal agriculture on the environment & 3.85 \\
\hline & $\begin{array}{l}\text { Facilities needed to housed and produce animal species } \\
\text { safely and efficiently }\end{array}$ & 15.38 \\
\hline & $\begin{array}{l}\text { Foods derived from meat, egg, poultry, fish and dairy } \\
\text { products }\end{array}$ & 3.85 \\
\hline
\end{tabular}


Table Appendix 5

Percent of Respondents Using Particular Delivery Method for Each Content Skill Sets

\begin{tabular}{|c|c|c|}
\hline Method & Content Skill Set & Mean \\
\hline & Functions of plant parts & 11.54 \\
\hline & $\begin{array}{l}\text { Identify agriculturally important plants by common } \\
\text { names }\end{array}$ & 3.85 \\
\hline & Identify alternative energy sources & 3.85 \\
\hline & Identify healthy ecosystem characteristics & .00 \\
\hline & Identify nonrenewable resources & .00 \\
\hline & Identify renewable resources & 3.85 \\
\hline & Identify the components and functions of plant roots & .00 \\
\hline & $\begin{array}{l}\text { Identify the components and the functions of plant } \\
\text { flowers }\end{array}$ & 3.85 \\
\hline & $\begin{array}{l}\text { Identify the components and the functions of plant } \\
\text { leaves }\end{array}$ & .00 \\
\hline & $\begin{array}{l}\text { Identify the components and the functions of plant } \\
\text { stems }\end{array}$ & .00 \\
\hline & $\begin{array}{l}\text { Interpret soil results to determine fertilizer application } \\
\text { needs }\end{array}$ & 15.38 \\
\hline & Livestock terminology (steer, heifer, barrow, gilt, etc.) & 3.85 \\
\hline & Methods of food preservations & 19.23 \\
\hline & $\begin{array}{l}\text { Methods of marketing agricultural commodities, } \\
\text { products and services in domestic and international } \\
\text { markets }\end{array}$ & 11.54 \\
\hline & Natural resources & 3.85 \\
\hline & Nonrenewable resources & 3.85 \\
\hline & Parts of a plant & 19.23 \\
\hline & Perform a basic health exam on a live animal & 30.77 \\
\hline
\end{tabular}


Table Appendix 5

Percent of Respondents Using Particular Delivery Method for Each Content Skill Sets

\begin{tabular}{|c|c|c|}
\hline Method & Content Skill Set & Mean \\
\hline & $\begin{array}{l}\text { Plant physiology - photosynthesis, reproduction, } \\
\text { respiration, transpiration }\end{array}$ & 3.85 \\
\hline & Practice administering injections & 23.08 \\
\hline & $\begin{array}{l}\text { Produce a food product (cheese, sausage, sauerkraut, } \\
\text { etc.) }\end{array}$ & 26.92 \\
\hline & Products derived from fruits and vegetables & 3.85 \\
\hline & Products derived from grains, legumes and oilseeds & 3.85 \\
\hline & Properly and safely used hand tools & 34.62 \\
\hline & Quality and yield grades of food products & 15.38 \\
\hline & Recite the FFA Creed & 23.08 \\
\hline & Recite the FFA motto & 23.08 \\
\hline & Renewable resources & .00 \\
\hline & $\begin{array}{l}\text { Research current agricultural products impacted by } \\
\text { biotechnology practices }\end{array}$ & .00 \\
\hline & $\begin{array}{l}\text { Research local supply and demand of agricultural } \\
\text { products }\end{array}$ & 7.69 \\
\hline & $\begin{array}{l}\text { Research the important dates and events in the history } \\
\text { of FFA and Agricultural Education }\end{array}$ & .00 \\
\hline & Return on investment & 19.23 \\
\hline & $\begin{array}{l}\text { Students will demonstrate knowledge of FFA history, } \\
\text { Code of Ethics and Official Dress }\end{array}$ & 19.23 \\
\hline & Supervised Agricultural Experience Program (SAE) & 11.54 \\
\hline & $\begin{array}{l}\text { The basic hand tools and their proper used in an } \\
\text { agricultural setting }\end{array}$ & 23.08 \\
\hline & The Four Ps (product, place, price and promotion) & 11.54 \\
\hline
\end{tabular}


Table Appendix 5

Percent of Respondents Using Particular Delivery Method for Each Content Skill Sets

\begin{tabular}{|c|c|c|}
\hline Method & Content Skill Set & Mean \\
\hline & The history of agriculture innovation & .00 \\
\hline & The history of the animal processing industry & 7.69 \\
\hline & The importance of food labeling to the consumer & 3.85 \\
\hline & $\begin{array}{l}\text { The major agriculture inventions and their impact on } \\
\text { the industry. }\end{array}$ & .00 \\
\hline & $\begin{array}{l}\text { The origin, significance, distribution and domestication } \\
\text { of animal systems }\end{array}$ & .00 \\
\hline & Types of agribusiness ownership & 23.08 \\
\hline & Units of weight, volume, and temperature & 7.69 \\
\hline & $\begin{array}{l}\text { Used a ruler, a metric ruler, and a measuring tape to } \\
\text { measure }\end{array}$ & 30.77 \\
\hline & Used agricultural related technology and equipment & 3.85 \\
\hline \multirow[t]{9}{*}{ Lecture } & $\begin{array}{l}\text { Add, subtract, multiply, and divide decimals, with and } \\
\text { without a calculator }\end{array}$ & 19.23 \\
\hline & Add, subtract, multiply, and divide fractions & 19.23 \\
\hline & $\begin{array}{l}\text { Add, subtract, multiply, and divide whole numbers, } \\
\text { with and without a calculator }\end{array}$ & 23.08 \\
\hline & Agricultural biotechnology & 19.23 \\
\hline & Animal cells & 26.92 \\
\hline & Animal health disorders & 30.77 \\
\hline & Animal welfare and animal rights & 30.77 \\
\hline & Applications of biotechnology in agriculture & 15.38 \\
\hline & Basic anatomy of animals & 23.08 \\
\hline
\end{tabular}


Table Appendix 5

Percent of Respondents Using Particular Delivery Method for Each Content Skill Sets

\begin{tabular}{|c|c|c|}
\hline Method & Content Skill Set & Mean \\
\hline & $\begin{array}{l}\text { Basic finance - personal inventory, net worth, income, } \\
\text { expense }\end{array}$ & 34.62 \\
\hline & $\begin{array}{l}\text { Basic math practices used in power, structural and } \\
\text { technical systems }\end{array}$ & 23.08 \\
\hline & Basic plant nutrition & 38.46 \\
\hline & Basic soil science & 34.62 \\
\hline & Bio-security in the animal industry & 34.62 \\
\hline & Breeds of livestock & 30.77 \\
\hline & Common and scientific names of major animal species & 50.00 \\
\hline & Common types of feedstuffs & 34.62 \\
\hline & $\begin{array}{l}\text { Common weights and measures in the food products } \\
\text { and processing industry }\end{array}$ & 30.77 \\
\hline & Compare and contrast various food labels & 15.38 \\
\hline & Conduct a food preservation experiment. & 7.69 \\
\hline & Conduct soil sampling and testing & 19.23 \\
\hline & Construct a project using hand tools & 19.23 \\
\hline & $\begin{array}{l}\text { Convert decimals to percentages and percentages to } \\
\text { decimals }\end{array}$ & 19.23 \\
\hline & Convert fractions to decimal and decimals to fractions & 19.23 \\
\hline & Create a plan for their own agricultural enterprises & 23.08 \\
\hline & Create an advertisement for an agricultural product & 11.54 \\
\hline & $\begin{array}{l}\text { Debate the issues associated with animal welfare and } \\
\text { animal rights }\end{array}$ & 15.38 \\
\hline & Debate the issues associated with biotechnology & 19.23 \\
\hline
\end{tabular}


Table Appendix 5

Percent of Respondents Using Particular Delivery Method for Each Content Skill Sets

\begin{tabular}{|c|c|c|}
\hline Method & Content Skill Set & Mean \\
\hline & $\begin{array}{l}\text { Diagram a typical animal cell and identify the } \\
\text { organelles }\end{array}$ & 23.08 \\
\hline & $\begin{array}{l}\text { Diagram a typical plant cell and identify plant cell } \\
\text { organelles and their functions }\end{array}$ & 30.77 \\
\hline & Ecosystems & 34.62 \\
\hline & Effects of animal agriculture on the environment & 30.77 \\
\hline & $\begin{array}{l}\text { Facilities needed to housed and produce animal species } \\
\text { safely and efficiently }\end{array}$ & 30.77 \\
\hline & $\begin{array}{l}\text { Foods derived from meat, egg, poultry, fish and dairy } \\
\text { products }\end{array}$ & 26.92 \\
\hline & Functions of plant parts & 34.62 \\
\hline & $\begin{array}{l}\text { Identify agriculturally important plants by common } \\
\text { names }\end{array}$ & 30.77 \\
\hline & Identify alternative energy sources & 30.77 \\
\hline & Identify healthy ecosystem characteristics & 30.77 \\
\hline & Identify nonrenewable resources & 23.08 \\
\hline & Identify renewable resources & 26.92 \\
\hline & Identify the components and functions of plant roots & 34.62 \\
\hline & $\begin{array}{l}\text { Identify the components and the functions of plant } \\
\text { flowers }\end{array}$ & 30.77 \\
\hline & $\begin{array}{l}\text { Identify the components and the functions of plant } \\
\text { leaves }\end{array}$ & 26.92 \\
\hline & $\begin{array}{l}\text { Identify the components and the functions of plant } \\
\text { stems }\end{array}$ & 30.77 \\
\hline & $\begin{array}{l}\text { Interpret soil results to determine fertilizer application } \\
\text { needs }\end{array}$ & 26.92 \\
\hline
\end{tabular}


Table Appendix 5

Percent of Respondents Using Particular Delivery Method for Each Content Skill Sets

\begin{tabular}{|c|c|c|}
\hline Method & Content Skill Set & Mean \\
\hline & Livestock terminology (steer, heifer, barrow, gilt, etc.) & 42.31 \\
\hline & Methods of food preservations & 30.77 \\
\hline & $\begin{array}{l}\text { Methods of marketing agricultural commodities, } \\
\text { products and services in domestic and international } \\
\text { markets }\end{array}$ & 42.31 \\
\hline & Natural resources & 46.15 \\
\hline & Nonrenewable resources & 30.77 \\
\hline & Parts of a plant & 30.77 \\
\hline & Perform a basic health exam on a live animal & 15.38 \\
\hline & $\begin{array}{l}\text { Plant physiology - photosynthesis, reproduction, } \\
\text { respiration, transpiration }\end{array}$ & 42.31 \\
\hline & Practice administering injections & 7.69 \\
\hline & $\begin{array}{l}\text { Produce a food product (cheese, sausage, sauerkraut, } \\
\text { etc.) }\end{array}$ & 19.23 \\
\hline & Products derived from fruits and vegetables & 34.62 \\
\hline & Products derived from grains, legumes and oilseeds & 34.62 \\
\hline & Properly and safely used hand tools & 19.23 \\
\hline & Quality and yield grades of food products & 38.46 \\
\hline & Recite the FFA Creed & 26.92 \\
\hline & Recite the FFA motto & 30.77 \\
\hline & Renewable resources & 30.77 \\
\hline & $\begin{array}{l}\text { Research current agricultural products impacted by } \\
\text { biotechnology practices }\end{array}$ & 11.54 \\
\hline
\end{tabular}


Table Appendix 5

Percent of Respondents Using Particular Delivery Method for Each Content Skill Sets

\begin{tabular}{|c|c|c|}
\hline Method & Content Skill Set & Mean \\
\hline & $\begin{array}{l}\text { Research local supply and demand of agricultural } \\
\text { products }\end{array}$ & 19.23 \\
\hline & $\begin{array}{l}\text { Research the important dates and events in the history } \\
\text { of FFA and Agricultural Education }\end{array}$ & 30.77 \\
\hline & Return on investment & 38.46 \\
\hline & $\begin{array}{l}\text { Students will demonstrate knowledge of FFA history, } \\
\text { Code of Ethics and Official Dress }\end{array}$ & 42.31 \\
\hline & Supervised Agricultural Experience Program (SAE) & 46.15 \\
\hline & $\begin{array}{l}\text { The basic hand tools and their proper used in an } \\
\text { agricultural setting }\end{array}$ & 19.23 \\
\hline & The Four Ps (product, place, price and promotion) & 50.00 \\
\hline & The history of agriculture innovation & 30.77 \\
\hline & The history of the animal processing industry & 38.46 \\
\hline & The importance of food labeling to the consumer & 30.77 \\
\hline & $\begin{array}{l}\text { The major agriculture inventions and their impact on } \\
\text { the industry. }\end{array}$ & 23.08 \\
\hline & $\begin{array}{l}\text { The origin, significance, distribution and domestication } \\
\text { of animal systems }\end{array}$ & 46.15 \\
\hline & Types of agribusiness ownership & 46.15 \\
\hline & Units of weight, volume, and temperature & 23.08 \\
\hline & $\begin{array}{l}\text { Used a ruler, a metric ruler, and a measuring tape to } \\
\text { measure }\end{array}$ & 23.08 \\
\hline & Used agricultural related technology and equipment & 11.54 \\
\hline $\begin{array}{l}\text { Textbooks } \\
\text { Handouts }\end{array}$ & $\begin{array}{l}\text { Add, subtract, multiply, and divide decimals, with and } \\
\text { without a calculator }\end{array}$ & 23.08 \\
\hline
\end{tabular}


Table Appendix 5

Percent of Respondents Using Particular Delivery Method for Each Content Skill Sets

\begin{tabular}{|c|c|c|}
\hline Method & Content Skill Set & Mean \\
\hline & Add, subtract, multiply, and divide fractions & 23.08 \\
\hline & $\begin{array}{l}\text { Add, subtract, multiply, and divide whole numbers, } \\
\text { with and without a calculator }\end{array}$ & 30.77 \\
\hline & Agricultural biotechnology & 26.92 \\
\hline & Animal cells & 30.77 \\
\hline & Animal health disorders & 34.62 \\
\hline & Animal welfare and animal rights & 23.08 \\
\hline & Applications of biotechnology in agriculture & 19.23 \\
\hline & Basic anatomy of animals & 23.08 \\
\hline & $\begin{array}{l}\text { Basic finance - personal inventory, net worth, income, } \\
\text { expense }\end{array}$ & 23.08 \\
\hline & $\begin{array}{l}\text { Basic math practices used in power, structural and } \\
\text { technical systems }\end{array}$ & 26.92 \\
\hline & Basic plant nutrition & 34.62 \\
\hline & Basic soil science & 42.31 \\
\hline & Bio-security in the animal industry & 30.77 \\
\hline & Breeds of livestock & 30.77 \\
\hline & Common and scientific names of major animal species & 30.77 \\
\hline & Common types of feedstuffs & 34.62 \\
\hline & $\begin{array}{l}\text { Common weights and measures in the food products } \\
\text { and processing industry }\end{array}$ & 23.08 \\
\hline & Compare and contrast various food labels & 15.38 \\
\hline & Conduct a food preservation experiment. & 3.85 \\
\hline
\end{tabular}


Table Appendix 5

Percent of Respondents Using Particular Delivery Method for Each Content Skill Sets

\begin{tabular}{|c|c|c|}
\hline Method & Content Skill Set & Mean \\
\hline & Conduct soil sampling and testing & 23.08 \\
\hline & Construct a project using hand tools & 19.23 \\
\hline & $\begin{array}{l}\text { Convert decimals to percentages and percentages to } \\
\text { decimals }\end{array}$ & 23.08 \\
\hline & Convert fractions to decimal and decimals to fractions & 23.08 \\
\hline & Create a plan for their own agricultural enterprises & 15.38 \\
\hline & Create an advertisement for an agricultural product & 15.38 \\
\hline & $\begin{array}{l}\text { Debate the issues associated with animal welfare and } \\
\text { animal rights }\end{array}$ & 19.23 \\
\hline & Debate the issues associated with biotechnology & 23.08 \\
\hline & $\begin{array}{l}\text { Diagram a typical animal cell and identify the } \\
\text { organelles }\end{array}$ & 42.31 \\
\hline & $\begin{array}{l}\text { Diagram a typical plant cell and identify plant cell } \\
\text { organelles and their functions }\end{array}$ & 34.62 \\
\hline & Ecosystems & 30.77 \\
\hline & Effects of animal agriculture on the environment & 23.08 \\
\hline & $\begin{array}{l}\text { Facilities needed to housed and produce animal species } \\
\text { safely and efficiently }\end{array}$ & 23.08 \\
\hline & $\begin{array}{l}\text { Foods derived from meat, egg, poultry, fish and dairy } \\
\text { products }\end{array}$ & 26.92 \\
\hline & Functions of plant parts & 38.46 \\
\hline & $\begin{array}{l}\text { Identify agriculturally important plants by common } \\
\text { names }\end{array}$ & 30.77 \\
\hline & Identify alternative energy sources & 26.92 \\
\hline & Identify healthy ecosystem characteristics & 34.62 \\
\hline
\end{tabular}


Table Appendix 5

Percent of Respondents Using Particular Delivery Method for Each Content Skill Sets

\begin{tabular}{|c|c|c|}
\hline Method & Content Skill Set & Mean \\
\hline & Identify nonrenewable resources & 26.92 \\
\hline & Identify renewable resources & 30.77 \\
\hline & Identify the components and functions of plant roots & 38.46 \\
\hline & $\begin{array}{l}\text { Identify the components and the functions of plant } \\
\text { flowers }\end{array}$ & 38.46 \\
\hline & $\begin{array}{l}\text { Identify the components and the functions of plant } \\
\text { leaves }\end{array}$ & 38.46 \\
\hline & $\begin{array}{l}\text { Identify the components and the functions of plant } \\
\text { stems }\end{array}$ & 38.46 \\
\hline & $\begin{array}{l}\text { Interpret soil results to determine fertilizer application } \\
\text { needs }\end{array}$ & 23.08 \\
\hline & Livestock terminology (steer, heifer, barrow, gilt, etc.) & 30.77 \\
\hline & Methods of food preservations & 11.54 \\
\hline & $\begin{array}{l}\text { Methods of marketing agricultural commodities, } \\
\text { products and services in domestic and international } \\
\text { markets }\end{array}$ & 11.54 \\
\hline & Natural resources & 30.77 \\
\hline & Nonrenewable resources & 34.62 \\
\hline & Parts of a plant & 38.46 \\
\hline & Perform a basic health exam on a live animal & 19.23 \\
\hline & $\begin{array}{l}\text { Plant physiology - photosynthesis, reproduction, } \\
\text { respiration, transpiration }\end{array}$ & 38.46 \\
\hline & Practice administering injections & 15.38 \\
\hline & $\begin{array}{l}\text { Produce a food product (cheese, sausage, sauerkraut, } \\
\text { etc.) }\end{array}$ & 15.38 \\
\hline
\end{tabular}


Table Appendix 5

Percent of Respondents Using Particular Delivery Method for Each Content Skill Sets

\begin{tabular}{|c|c|c|}
\hline Method & Content Skill Set & Mean \\
\hline & Products derived from fruits and vegetables & 26.92 \\
\hline & Products derived from grains, legumes and oilseeds & 26.92 \\
\hline & Properly and safely used hand tools & 19.23 \\
\hline & Quality and yield grades of food products & 26.92 \\
\hline & Recite the FFA Creed & 23.08 \\
\hline & Recite the FFA motto & 19.23 \\
\hline & Renewable resources & 38.46 \\
\hline & $\begin{array}{l}\text { Research current agricultural products impacted by } \\
\text { biotechnology practices }\end{array}$ & 19.23 \\
\hline & $\begin{array}{l}\text { Research local supply and demand of agricultural } \\
\text { products }\end{array}$ & 11.54 \\
\hline & $\begin{array}{l}\text { Research the important dates and events in the history } \\
\text { of FFA and Agricultural Education }\end{array}$ & 23.08 \\
\hline & Return on investment & 23.08 \\
\hline & $\begin{array}{l}\text { Students will demonstrate knowledge of FFA history, } \\
\text { Code of Ethics and Official Dress }\end{array}$ & 34.62 \\
\hline & Supervised Agricultural Experience Program (SAE) & 23.08 \\
\hline & $\begin{array}{l}\text { The basic hand tools and their proper used in an } \\
\text { agricultural setting }\end{array}$ & 23.08 \\
\hline & The Four Ps (product, place, price and promotion) & 19.23 \\
\hline & The history of agriculture innovation & 38.46 \\
\hline & The history of the animal processing industry & 11.54 \\
\hline & The importance of food labeling to the consumer & 11.54 \\
\hline
\end{tabular}


Table Appendix 5

Percent of Respondents Using Particular Delivery Method for Each Content Skill Sets

\begin{tabular}{|c|c|c|}
\hline Method & Content Skill Set & Mean \\
\hline & $\begin{array}{l}\text { The major agriculture inventions and their impact on } \\
\text { the industry. }\end{array}$ & 30.77 \\
\hline & $\begin{array}{l}\text { The origin, significance, distribution and domestication } \\
\text { of animal systems }\end{array}$ & 23.08 \\
\hline & Types of agribusiness ownership & 34.62 \\
\hline & Units of weight, volume, and temperature & 23.08 \\
\hline & $\begin{array}{l}\text { Used a ruler, a metric ruler, and a measuring tape to } \\
\text { measure }\end{array}$ & 23.08 \\
\hline & Used agricultural related technology and equipment & 23.08 \\
\hline \multirow[t]{12}{*}{ Mechanics } & $\begin{array}{l}\text { Add, subtract, multiply, and divide decimals, with and } \\
\text { without a calculator }\end{array}$ & 23.08 \\
\hline & Add, subtract, multiply, and divide fractions & 23.08 \\
\hline & $\begin{array}{l}\text { Add, subtract, multiply, and divide whole numbers, } \\
\text { with and without a calculator }\end{array}$ & 23.08 \\
\hline & Agricultural biotechnology & .00 \\
\hline & Animal cells & .00 \\
\hline & Animal health disorders & .00 \\
\hline & Animal welfare and animal rights & .00 \\
\hline & Applications of biotechnology in agriculture & .00 \\
\hline & Basic anatomy of animals & .00 \\
\hline & $\begin{array}{l}\text { Basic finance - personal inventory, net worth, income, } \\
\text { expense }\end{array}$ & 3.85 \\
\hline & $\begin{array}{l}\text { Basic math practices used in power, structural and } \\
\text { technical systems }\end{array}$ & 23.08 \\
\hline & Basic plant nutrition & .00 \\
\hline
\end{tabular}


Table Appendix 5

Percent of Respondents Using Particular Delivery Method for Each Content Skill Sets

\begin{tabular}{|c|c|c|}
\hline Method & Content Skill Set & Mean \\
\hline & Basic soil science & .00 \\
\hline & Bio-security in the animal industry & .00 \\
\hline & Breeds of livestock & .00 \\
\hline & Common and scientific names of major animal species & .00 \\
\hline & Common types of feedstuffs & .00 \\
\hline & $\begin{array}{l}\text { Common weights and measures in the food products } \\
\text { and processing industry }\end{array}$ & .00 \\
\hline & Compare and contrast various food labels & .00 \\
\hline & Conduct a food preservation experiment. & .00 \\
\hline & Conduct soil sampling and testing & .00 \\
\hline & Construct a project using hand tools & 34.62 \\
\hline & $\begin{array}{l}\text { Convert decimals to percentages and percentages to } \\
\text { decimals }\end{array}$ & 19.23 \\
\hline & Convert fractions to decimal and decimals to fractions & 15.38 \\
\hline & Create a plan for their own agricultural enterprises & 11.54 \\
\hline & Create an advertisement for an agricultural product & 11.54 \\
\hline & $\begin{array}{l}\text { Debate the issues associated with animal welfare and } \\
\text { animal rights }\end{array}$ & 3.85 \\
\hline & Debate the issues associated with biotechnology & .00 \\
\hline & $\begin{array}{l}\text { Diagram a typical animal cell and identify the } \\
\text { organelles }\end{array}$ & .00 \\
\hline & $\begin{array}{l}\text { Diagram a typical plant cell and identify plant cell } \\
\text { organelles and their functions }\end{array}$ & .00 \\
\hline & Ecosystems & .00 \\
\hline
\end{tabular}


Table Appendix 5

Percent of Respondents Using Particular Delivery Method for Each Content Skill Sets

\begin{tabular}{|c|c|c|}
\hline Method & Content Skill Set & Mean \\
\hline & Effects of animal agriculture on the environment & .00 \\
\hline & $\begin{array}{l}\text { Facilities needed to housed and produce animal species } \\
\text { safely and efficiently }\end{array}$ & 3.85 \\
\hline & $\begin{array}{l}\text { Foods derived from meat, egg, poultry, fish and dairy } \\
\text { products }\end{array}$ & .00 \\
\hline & Functions of plant parts & .00 \\
\hline & $\begin{array}{l}\text { Identify agriculturally important plants by common } \\
\text { names }\end{array}$ & .00 \\
\hline & Identify alternative energy sources & .00 \\
\hline & Identify healthy ecosystem characteristics & .00 \\
\hline & Identify nonrenewable resources & .00 \\
\hline & Identify renewable resources & .00 \\
\hline & Identify the components and functions of plant roots & .00 \\
\hline & $\begin{array}{l}\text { Identify the components and the functions of plant } \\
\text { flowers }\end{array}$ & .00 \\
\hline & $\begin{array}{l}\text { Identify the components and the functions of plant } \\
\text { leaves }\end{array}$ & .00 \\
\hline & $\begin{array}{l}\text { Identify the components and the functions of plant } \\
\text { stems }\end{array}$ & .00 \\
\hline & $\begin{array}{l}\text { Interpret soil results to determine fertilizer application } \\
\text { needs }\end{array}$ & .00 \\
\hline & Livestock terminology (steer, heifer, barrow, gilt, etc.) & .00 \\
\hline & Methods of food preservations & .00 \\
\hline & $\begin{array}{l}\text { Methods of marketing agricultural commodities, } \\
\text { products and services in domestic and international } \\
\text { markets }\end{array}$ & 3.85 \\
\hline
\end{tabular}


Table Appendix 5

Percent of Respondents Using Particular Delivery Method for Each Content Skill Sets

\begin{tabular}{|c|c|c|}
\hline Method & Content Skill Set & Mean \\
\hline & Natural resources & .00 \\
\hline & Nonrenewable resources & .00 \\
\hline & Parts of a plant & .00 \\
\hline & Perform a basic health exam on a live animal & 3.85 \\
\hline & $\begin{array}{l}\text { Plant physiology - photosynthesis, reproduction, } \\
\text { respiration, transpiration }\end{array}$ & .00 \\
\hline & Practice administering injections & .00 \\
\hline & $\begin{array}{l}\text { Produce a food product (cheese, sausage, sauerkraut, } \\
\text { etc.) }\end{array}$ & .00 \\
\hline & Products derived from fruits and vegetables & .00 \\
\hline & Products derived from grains, legumes and oilseeds & .00 \\
\hline & Properly and safely used hand tools & 34.62 \\
\hline & Quality and yield grades of food products & .00 \\
\hline & Recite the FFA Creed & .00 \\
\hline & Recite the FFA motto & .00 \\
\hline & Renewable resources & .00 \\
\hline & $\begin{array}{l}\text { Research current agricultural products impacted by } \\
\text { biotechnology practices }\end{array}$ & .00 \\
\hline & $\begin{array}{l}\text { Research local supply and demand of agricultural } \\
\text { products }\end{array}$ & 3.85 \\
\hline & $\begin{array}{l}\text { Research the important dates and events in the history } \\
\text { of FFA and Agricultural Education }\end{array}$ & .00 \\
\hline & Return on investment & 7.69 \\
\hline
\end{tabular}


Table Appendix 5

Percent of Respondents Using Particular Delivery Method for Each Content Skill Sets

\begin{tabular}{|c|c|c|}
\hline Method & Content Skill Set & Mean \\
\hline & $\begin{array}{l}\text { Students will demonstrate knowledge of FFA history, } \\
\text { Code of Ethics and Official Dress }\end{array}$ & .00 \\
\hline & Supervised Agricultural Experience Program (SAE) & 19.23 \\
\hline & $\begin{array}{l}\text { The basic hand tools and their proper used in an } \\
\text { agricultural setting }\end{array}$ & 30.77 \\
\hline & The Four Ps (product, place, price and promotion) & 11.54 \\
\hline & The history of agriculture innovation & .00 \\
\hline & The history of the animal processing industry & .00 \\
\hline & The importance of food labeling to the consumer & .00 \\
\hline & $\begin{array}{l}\text { The major agriculture inventions and their impact on } \\
\text { the industry. }\end{array}$ & 3.85 \\
\hline & $\begin{array}{l}\text { The origin, significance, distribution and domestication } \\
\text { of animal systems }\end{array}$ & .00 \\
\hline & Types of agribusiness ownership & 15.38 \\
\hline & Units of weight, volume, and temperature & 19.23 \\
\hline & $\begin{array}{l}\text { Used a ruler, a metric ruler, and a measuring tape to } \\
\text { measure }\end{array}$ & 26.92 \\
\hline & Used agricultural related technology and equipment & 7.69 \\
\hline \multirow[t]{5}{*}{ Greenhouse } & $\begin{array}{l}\text { Add, subtract, multiply, and divide decimals, with and } \\
\text { without a calculator }\end{array}$ & 11.54 \\
\hline & Add, subtract, multiply, and divide fractions & 11.54 \\
\hline & $\begin{array}{l}\text { Add, subtract, multiply, and divide whole numbers, } \\
\text { with and without a calculator }\end{array}$ & 7.69 \\
\hline & Agricultural biotechnology & 3.85 \\
\hline & Animal cells & .00 \\
\hline
\end{tabular}


Table Appendix 5

Percent of Respondents Using Particular Delivery Method for Each Content Skill Sets

\begin{tabular}{|c|c|c|}
\hline Method & Content Skill Set & Mean \\
\hline & Animal health disorders & .00 \\
\hline & Animal welfare and animal rights & .00 \\
\hline & Applications of biotechnology in agriculture & .00 \\
\hline & Basic anatomy of animals & .00 \\
\hline & $\begin{array}{l}\text { Basic finance - personal inventory, net worth, income, } \\
\text { expense }\end{array}$ & 26.92 \\
\hline & $\begin{array}{l}\text { Basic math practices used in power, structural and } \\
\text { technical systems }\end{array}$ & 3.85 \\
\hline & Basic plant nutrition & 30.77 \\
\hline & Basic soil science & 19.23 \\
\hline & Bio-security in the animal industry & .00 \\
\hline & Breeds of livestock & .00 \\
\hline & Common and scientific names of major animal species & .00 \\
\hline & Common types of feedstuffs & .00 \\
\hline & $\begin{array}{l}\text { Common weights and measures in the food products } \\
\text { and processing industry }\end{array}$ & 3.85 \\
\hline & Compare and contrast various food labels & .00 \\
\hline & Conduct a food preservation experiment. & .00 \\
\hline & Conduct soil sampling and testing & 26.92 \\
\hline & Construct a project using hand tools & 7.69 \\
\hline & $\begin{array}{l}\text { Convert decimals to percentages and percentages to } \\
\text { decimals }\end{array}$ & 11.54 \\
\hline & Convert fractions to decimal and decimals to fractions & 3.85 \\
\hline
\end{tabular}


Table Appendix 5

Percent of Respondents Using Particular Delivery Method for Each Content Skill Sets

\begin{tabular}{|c|c|c|}
\hline Method & Content Skill Set & Mean \\
\hline & Create a plan for their own agricultural enterprises & 19.23 \\
\hline & Create an advertisement for an agricultural product & 30.77 \\
\hline & $\begin{array}{l}\text { Debate the issues associated with animal welfare and } \\
\text { animal rights }\end{array}$ & .00 \\
\hline & Debate the issues associated with biotechnology & .00 \\
\hline & $\begin{array}{l}\text { Diagram a typical animal cell and identify the } \\
\text { organelles }\end{array}$ & .00 \\
\hline & $\begin{array}{l}\text { Diagram a typical plant cell and identify plant cell } \\
\text { organelles and their functions }\end{array}$ & 26.92 \\
\hline & Ecosystems & .00 \\
\hline & Effects of animal agriculture on the environment & .00 \\
\hline & $\begin{array}{l}\text { Facilities needed to housed and produce animal species } \\
\text { safely and efficiently }\end{array}$ & .00 \\
\hline & $\begin{array}{l}\text { Foods derived from meat, egg, poultry, fish and dairy } \\
\text { products }\end{array}$ & .00 \\
\hline & Functions of plant parts & 34.62 \\
\hline & $\begin{array}{l}\text { Identify agriculturally important plants by common } \\
\text { names }\end{array}$ & 26.92 \\
\hline & Identify alternative energy sources & 3.85 \\
\hline & Identify healthy ecosystem characteristics & .00 \\
\hline & Identify nonrenewable resources & .00 \\
\hline & Identify renewable resources & .00 \\
\hline & Identify the components and functions of plant roots & 30.77 \\
\hline & $\begin{array}{l}\text { Identify the components and the functions of plant } \\
\text { flowers }\end{array}$ & 30.77 \\
\hline
\end{tabular}


Table Appendix 5

Percent of Respondents Using Particular Delivery Method for Each Content Skill Sets

\begin{tabular}{|c|c|c|}
\hline Method & Content Skill Set & Mean \\
\hline & $\begin{array}{l}\text { Identify the components and the functions of plant } \\
\text { leaves }\end{array}$ & 30.77 \\
\hline & $\begin{array}{l}\text { Identify the components and the functions of plant } \\
\text { stems }\end{array}$ & 26.92 \\
\hline & $\begin{array}{l}\text { Interpret soil results to determine fertilizer application } \\
\text { needs }\end{array}$ & 34.62 \\
\hline & Livestock terminology (steer, heifer, barrow, gilt, etc.) & .00 \\
\hline & Methods of food preservations & .00 \\
\hline & $\begin{array}{l}\text { Methods of marketing agricultural commodities, } \\
\text { products and services in domestic and international } \\
\text { markets }\end{array}$ & 23.08 \\
\hline & Natural resources & 3.85 \\
\hline & Nonrenewable resources & .00 \\
\hline & Parts of a plant & 34.62 \\
\hline & Perform a basic health exam on a live animal & .00 \\
\hline & $\begin{array}{l}\text { Plant physiology - photosynthesis, reproduction, } \\
\text { respiration, transpiration }\end{array}$ & 23.08 \\
\hline & Practice administering injections & .00 \\
\hline & $\begin{array}{l}\text { Produce a food product (cheese, sausage, sauerkraut, } \\
\text { etc.) }\end{array}$ & .00 \\
\hline & Products derived from fruits and vegetables & 3.85 \\
\hline & Products derived from grains, legumes and oilseeds & 3.85 \\
\hline & Properly and safely used hand tools & 7.69 \\
\hline & Quality and yield grades of food products & .00 \\
\hline & Recite the FFA Creed & .00 \\
\hline
\end{tabular}


Table Appendix 5

Percent of Respondents Using Particular Delivery Method for Each Content Skill Sets

\begin{tabular}{|c|c|c|}
\hline Method & Content Skill Set & Mean \\
\hline & Recite the FFA motto & .00 \\
\hline & Renewable resources & 3.85 \\
\hline & $\begin{array}{l}\text { Research current agricultural products impacted by } \\
\text { biotechnology practices }\end{array}$ & 3.85 \\
\hline & $\begin{array}{l}\text { Research local supply and demand of agricultural } \\
\text { products }\end{array}$ & 23.08 \\
\hline & $\begin{array}{l}\text { Research the important dates and events in the history } \\
\text { of FFA and Agricultural Education }\end{array}$ & .00 \\
\hline & Return on investment & 23.08 \\
\hline & $\begin{array}{l}\text { Students will demonstrate knowledge of FFA history, } \\
\text { Code of Ethics and Official Dress }\end{array}$ & .00 \\
\hline & Supervised Agricultural Experience Program (SAE) & 46.15 \\
\hline & $\begin{array}{l}\text { The basic hand tools and their proper used in an } \\
\text { agricultural setting }\end{array}$ & 3.85 \\
\hline & The Four Ps (product, place, price and promotion) & 23.08 \\
\hline & The history of agriculture innovation & 3.85 \\
\hline & The history of the animal processing industry & .00 \\
\hline & The importance of food labeling to the consumer & .00 \\
\hline & $\begin{array}{l}\text { The major agriculture inventions and their impact on } \\
\text { the industry. }\end{array}$ & .00 \\
\hline & $\begin{array}{l}\text { The origin, significance, distribution and domestication } \\
\text { of animal systems }\end{array}$ & .00 \\
\hline & Types of agribusiness ownership & 30.77 \\
\hline & Units of weight, volume, and temperature & .00 \\
\hline
\end{tabular}


Table Appendix 5

Percent of Respondents Using Particular Delivery Method for Each Content Skill Sets

\begin{tabular}{|c|c|c|}
\hline Method & Content Skill Set & Mean \\
\hline & $\begin{array}{l}\text { Used a ruler, a metric ruler, and a measuring tape to } \\
\text { measure }\end{array}$ & 7.69 \\
\hline & Used agricultural related technology and equipment & 7.69 \\
\hline \multirow[t]{17}{*}{ Meats } & $\begin{array}{l}\text { Add, subtract, multiply, and divide decimals, with and } \\
\text { without a calculator }\end{array}$ & 3.85 \\
\hline & Add, subtract, multiply, and divide fractions & 3.85 \\
\hline & $\begin{array}{l}\text { Add, subtract, multiply, and divide whole numbers, } \\
\text { with and without a calculator }\end{array}$ & .00 \\
\hline & Agricultural biotechnology & 3.85 \\
\hline & Animal cells & 3.85 \\
\hline & Animal health disorders & .00 \\
\hline & Animal welfare and animal rights & 7.69 \\
\hline & Applications of biotechnology in agriculture & .00 \\
\hline & Basic anatomy of animals & 15.38 \\
\hline & $\begin{array}{l}\text { Basic finance - personal inventory, net worth, income, } \\
\text { expense }\end{array}$ & 7.69 \\
\hline & $\begin{array}{l}\text { Basic math practices used in power, structural and } \\
\text { technical systems }\end{array}$ & .00 \\
\hline & Basic plant nutrition & .00 \\
\hline & Basic soil science & .00 \\
\hline & Bio-security in the animal industry & 3.85 \\
\hline & Breeds of livestock & 3.85 \\
\hline & Common and scientific names of major animal species & .00 \\
\hline & Common types of feedstuffs & 3.85 \\
\hline
\end{tabular}


Table Appendix 5

Percent of Respondents Using Particular Delivery Method for Each Content Skill Sets

\begin{tabular}{|c|c|c|}
\hline Method & Content Skill Set & Mean \\
\hline & $\begin{array}{l}\text { Common weights and measures in the food products } \\
\text { and processing industry }\end{array}$ & 7.69 \\
\hline & Compare and contrast various food labels & 15.38 \\
\hline & Conduct a food preservation experiment. & 7.69 \\
\hline & Conduct soil sampling and testing & .00 \\
\hline & Construct a project using hand tools & .00 \\
\hline & $\begin{array}{l}\text { Convert decimals to percentages and percentages to } \\
\text { decimals }\end{array}$ & 3.85 \\
\hline & Convert fractions to decimal and decimals to fractions & .00 \\
\hline & Create a plan for their own agricultural enterprises & 11.54 \\
\hline & Create an advertisement for an agricultural product & 15.38 \\
\hline & $\begin{array}{l}\text { Debate the issues associated with animal welfare and } \\
\text { animal rights }\end{array}$ & 3.85 \\
\hline & Debate the issues associated with biotechnology & .00 \\
\hline & $\begin{array}{l}\text { Diagram a typical animal cell and identify the } \\
\text { organelles }\end{array}$ & .00 \\
\hline & $\begin{array}{l}\text { Diagram a typical plant cell and identify plant cell } \\
\text { organelles and their functions }\end{array}$ & .00 \\
\hline & Ecosystems & .00 \\
\hline & Effects of animal agriculture on the environment & 7.69 \\
\hline & $\begin{array}{l}\text { Facilities needed to housed and produce animal species } \\
\text { safely and efficiently }\end{array}$ & .00 \\
\hline & $\begin{array}{l}\text { Foods derived from meat, egg, poultry, fish and dairy } \\
\text { products }\end{array}$ & 11.54 \\
\hline & Functions of plant parts & .00 \\
\hline
\end{tabular}


Table Appendix 5

Percent of Respondents Using Particular Delivery Method for Each Content Skill Sets

\begin{tabular}{|c|c|c|}
\hline Method & Content Skill Set & Mean \\
\hline & $\begin{array}{l}\text { Identify agriculturally important plants by common } \\
\text { names }\end{array}$ & .00 \\
\hline & Identify alternative energy sources & .00 \\
\hline & Identify healthy ecosystem characteristics & .00 \\
\hline & Identify nonrenewable resources & .00 \\
\hline & Identify renewable resources & .00 \\
\hline & Identify the components and functions of plant roots & .00 \\
\hline & $\begin{array}{l}\text { Identify the components and the functions of plant } \\
\text { flowers }\end{array}$ & .00 \\
\hline & $\begin{array}{l}\text { Identify the components and the functions of plant } \\
\text { leaves }\end{array}$ & .00 \\
\hline & $\begin{array}{l}\text { Identify the components and the functions of plant } \\
\text { stems }\end{array}$ & .00 \\
\hline & $\begin{array}{l}\text { Interpret soil results to determine fertilizer application } \\
\text { needs }\end{array}$ & .00 \\
\hline & Livestock terminology (steer, heifer, barrow, gilt, etc.) & .00 \\
\hline & Methods of food preservations & 19.23 \\
\hline & $\begin{array}{l}\text { Methods of marketing agricultural commodities, } \\
\text { products and services in domestic and international } \\
\text { markets }\end{array}$ & 11.54 \\
\hline & Natural resources & .00 \\
\hline & Nonrenewable resources & .00 \\
\hline & Parts of a plant & .00 \\
\hline & Perform a basic health exam on a live animal & .00 \\
\hline
\end{tabular}


Table Appendix 5

Percent of Respondents Using Particular Delivery Method for Each Content Skill Sets

\begin{tabular}{|c|c|c|}
\hline Method & Content Skill Set & Mean \\
\hline & $\begin{array}{l}\text { Plant physiology - photosynthesis, reproduction, } \\
\text { respiration, transpiration }\end{array}$ & .00 \\
\hline & Practice administering injections & 3.85 \\
\hline & $\begin{array}{l}\text { Produce a food product (cheese, sausage, sauerkraut, } \\
\text { etc.) }\end{array}$ & 23.08 \\
\hline & Products derived from fruits and vegetables & 3.85 \\
\hline & Products derived from grains, legumes and oilseeds & 3.85 \\
\hline & Properly and safely used hand tools & .00 \\
\hline & Quality and yield grades of food products & 15.38 \\
\hline & Recite the FFA Creed & .00 \\
\hline & Recite the FFA motto & .00 \\
\hline & Renewable resources & .00 \\
\hline & $\begin{array}{l}\text { Research current agricultural products impacted by } \\
\text { biotechnology practices }\end{array}$ & .00 \\
\hline & $\begin{array}{l}\text { Research local supply and demand of agricultural } \\
\text { products }\end{array}$ & 11.54 \\
\hline & $\begin{array}{l}\text { Research the important dates and events in the history } \\
\text { of FFA and Agricultural Education }\end{array}$ & .00 \\
\hline & Return on investment & 11.54 \\
\hline & $\begin{array}{l}\text { Students will demonstrate knowledge of FFA history, } \\
\text { Code of Ethics and Official Dress }\end{array}$ & .00 \\
\hline & Supervised Agricultural Experience Program (SAE) & 15.38 \\
\hline & $\begin{array}{l}\text { The basic hand tools and their proper used in an } \\
\text { agricultural setting }\end{array}$ & .00 \\
\hline & The Four Ps (product, place, price and promotion) & 7.69 \\
\hline
\end{tabular}


Table Appendix 5

Percent of Respondents Using Particular Delivery Method for Each Content Skill Sets

\begin{tabular}{|c|c|c|}
\hline Method & Content Skill Set & Mean \\
\hline & The history of agriculture innovation & 3.85 \\
\hline & The history of the animal processing industry & 15.38 \\
\hline & The importance of food labeling to the consumer & 11.54 \\
\hline & $\begin{array}{l}\text { The major agriculture inventions and their impact on } \\
\text { the industry. }\end{array}$ & .00 \\
\hline & $\begin{array}{l}\text { The origin, significance, distribution and domestication } \\
\text { of animal systems }\end{array}$ & 3.85 \\
\hline & Types of agribusiness ownership & 15.38 \\
\hline & Units of weight, volume, and temperature & 3.85 \\
\hline & $\begin{array}{l}\text { Used a ruler, a metric ruler, and a measuring tape to } \\
\text { measure }\end{array}$ & 3.85 \\
\hline & Used agricultural related technology and equipment & 3.85 \\
\hline \multirow[t]{9}{*}{ Biotechnology } & $\begin{array}{l}\text { Add, subtract, multiply, and divide decimals, with and } \\
\text { without a calculator }\end{array}$ & .00 \\
\hline & Add, subtract, multiply, and divide fractions & .00 \\
\hline & $\begin{array}{l}\text { Add, subtract, multiply, and divide whole numbers, } \\
\text { with and without a calculator }\end{array}$ & .00 \\
\hline & Agricultural biotechnology & 11.54 \\
\hline & Animal cells & 3.85 \\
\hline & Animal health disorders & .00 \\
\hline & Animal welfare and animal rights & .00 \\
\hline & Applications of biotechnology in agriculture & 11.54 \\
\hline & Basic anatomy of animals & .00 \\
\hline
\end{tabular}


Table Appendix 5

Percent of Respondents Using Particular Delivery Method for Each Content Skill Sets

\begin{tabular}{|c|c|c|}
\hline Method & Content Skill Set & Mean \\
\hline & $\begin{array}{l}\text { Basic finance - personal inventory, net worth, income, } \\
\text { expense }\end{array}$ & .00 \\
\hline & $\begin{array}{l}\text { Basic math practices used in power, structural and } \\
\text { technical systems }\end{array}$ & .00 \\
\hline & Basic plant nutrition & 7.69 \\
\hline & Basic soil science & 7.69 \\
\hline & Bio-security in the animal industry & 3.85 \\
\hline & Breeds of livestock & .00 \\
\hline & Common and scientific names of major animal species & .00 \\
\hline & Common types of feedstuffs & .00 \\
\hline & $\begin{array}{l}\text { Common weights and measures in the food products } \\
\text { and processing industry }\end{array}$ & .00 \\
\hline & Compare and contrast various food labels & .00 \\
\hline & Conduct a food preservation experiment. & .00 \\
\hline & Conduct soil sampling and testing & 3.85 \\
\hline & Construct a project using hand tools & .00 \\
\hline & $\begin{array}{l}\text { Convert decimals to percentages and percentages to } \\
\text { decimals }\end{array}$ & .00 \\
\hline & Convert fractions to decimal and decimals to fractions & .00 \\
\hline & Create a plan for their own agricultural enterprises & 3.85 \\
\hline & Create an advertisement for an agricultural product & .00 \\
\hline & $\begin{array}{l}\text { Debate the issues associated with animal welfare and } \\
\text { animal rights }\end{array}$ & 3.85 \\
\hline & Debate the issues associated with biotechnology & 3.85 \\
\hline
\end{tabular}


Table Appendix 5

Percent of Respondents Using Particular Delivery Method for Each Content Skill Sets

\begin{tabular}{|c|c|c|}
\hline Method & Content Skill Set & Mean \\
\hline & $\begin{array}{l}\text { Diagram a typical animal cell and identify the } \\
\text { organelles }\end{array}$ & .00 \\
\hline & $\begin{array}{l}\text { Diagram a typical plant cell and identify plant cell } \\
\text { organelles and their functions }\end{array}$ & 3.85 \\
\hline & Ecosystems & .00 \\
\hline & Effects of animal agriculture on the environment & .00 \\
\hline & $\begin{array}{l}\text { Facilities needed to housed and produce animal species } \\
\text { safely and efficiently }\end{array}$ & .00 \\
\hline & $\begin{array}{l}\text { Foods derived from meat, egg, poultry, fish and dairy } \\
\text { products }\end{array}$ & .00 \\
\hline & Functions of plant parts & 3.85 \\
\hline & $\begin{array}{l}\text { Identify agriculturally important plants by common } \\
\text { names }\end{array}$ & 3.85 \\
\hline & Identify alternative energy sources & .00 \\
\hline & Identify healthy ecosystem characteristics & .00 \\
\hline & Identify nonrenewable resources & .00 \\
\hline & Identify renewable resources & .00 \\
\hline & Identify the components and functions of plant roots & 7.69 \\
\hline & $\begin{array}{l}\text { Identify the components and the functions of plant } \\
\text { flowers }\end{array}$ & 7.69 \\
\hline & $\begin{array}{l}\text { Identify the components and the functions of plant } \\
\text { leaves }\end{array}$ & 7.69 \\
\hline & $\begin{array}{l}\text { Identify the components and the functions of plant } \\
\text { stems }\end{array}$ & 7.69 \\
\hline & $\begin{array}{l}\text { Interpret soil results to determine fertilizer application } \\
\text { needs }\end{array}$ & 3.85 \\
\hline
\end{tabular}


Table Appendix 5

Percent of Respondents Using Particular Delivery Method for Each Content Skill Sets

\begin{tabular}{|c|c|c|}
\hline Method & Content Skill Set & Mean \\
\hline & Livestock terminology (steer, heifer, barrow, gilt, etc.) & .00 \\
\hline & Methods of food preservations & .00 \\
\hline & $\begin{array}{l}\text { Methods of marketing agricultural commodities, } \\
\text { products and services in domestic and international } \\
\text { markets }\end{array}$ & .00 \\
\hline & Natural resources & .00 \\
\hline & Nonrenewable resources & 3.85 \\
\hline & Parts of a plant & 3.85 \\
\hline & Perform a basic health exam on a live animal & .00 \\
\hline & $\begin{array}{l}\text { Plant physiology - photosynthesis, reproduction, } \\
\text { respiration, transpiration }\end{array}$ & 7.69 \\
\hline & Practice administering injections & .00 \\
\hline & $\begin{array}{l}\text { Produce a food product (cheese, sausage, sauerkraut, } \\
\text { etc.) }\end{array}$ & .00 \\
\hline & Products derived from fruits and vegetables & .00 \\
\hline & Products derived from grains, legumes and oilseeds & .00 \\
\hline & Properly and safely used hand tools & .00 \\
\hline & Quality and yield grades of food products & .00 \\
\hline & Recite the FFA Creed & .00 \\
\hline & Recite the FFA motto & .00 \\
\hline & Renewable resources & 3.85 \\
\hline & $\begin{array}{l}\text { Research current agricultural products impacted by } \\
\text { biotechnology practices }\end{array}$ & .00 \\
\hline
\end{tabular}


Table Appendix 5

Percent of Respondents Using Particular Delivery Method for Each Content Skill Sets

\begin{tabular}{|c|c|c|}
\hline Method & Content Skill Set & Mean \\
\hline & $\begin{array}{l}\text { Research local supply and demand of agricultural } \\
\text { products }\end{array}$ & .00 \\
\hline & $\begin{array}{l}\text { Research the important dates and events in the history } \\
\text { of FFA and Agricultural Education }\end{array}$ & .00 \\
\hline & Return on investment & .00 \\
\hline & $\begin{array}{l}\text { Students will demonstrate knowledge of FFA history, } \\
\text { Code of Ethics and Official Dress }\end{array}$ & .00 \\
\hline & Supervised Agricultural Experience Program (SAE) & 3.85 \\
\hline & $\begin{array}{l}\text { The basic hand tools and their proper used in an } \\
\text { agricultural setting }\end{array}$ & .00 \\
\hline & The Four Ps (product, place, price and promotion) & .00 \\
\hline & The history of agriculture innovation & 3.85 \\
\hline & The history of the animal processing industry & .00 \\
\hline & The importance of food labeling to the consumer & .00 \\
\hline & $\begin{array}{l}\text { The major agriculture inventions and their impact on } \\
\text { the industry. }\end{array}$ & .00 \\
\hline & $\begin{array}{l}\text { The origin, significance, distribution and domestication } \\
\text { of animal systems }\end{array}$ & .00 \\
\hline & Types of agribusiness ownership & 7.69 \\
\hline & Units of weight, volume, and temperature & 3.85 \\
\hline & $\begin{array}{l}\text { Used a ruler, a metric ruler, and a measuring tape to } \\
\text { measure }\end{array}$ & .00 \\
\hline & Used agricultural related technology and equipment & 3.85 \\
\hline Land & $\begin{array}{l}\text { Add, subtract, multiply, and divide decimals, with and } \\
\text { without a calculator }\end{array}$ & .00 \\
\hline
\end{tabular}


Table Appendix 5

Percent of Respondents Using Particular Delivery Method for Each Content Skill Sets

\begin{tabular}{|c|c|c|}
\hline Method & Content Skill Set & Mean \\
\hline & Add, subtract, multiply, and divide fractions & .00 \\
\hline & $\begin{array}{l}\text { Add, subtract, multiply, and divide whole numbers, } \\
\text { with and without a calculator }\end{array}$ & .00 \\
\hline & Agricultural biotechnology & .00 \\
\hline & Animal cells & .00 \\
\hline & Animal health disorders & .00 \\
\hline & Animal welfare and animal rights & .00 \\
\hline & Applications of biotechnology in agriculture & .00 \\
\hline & Basic anatomy of animals & .00 \\
\hline & $\begin{array}{l}\text { Basic finance - personal inventory, net worth, income, } \\
\text { expense }\end{array}$ & 3.85 \\
\hline & $\begin{array}{l}\text { Basic math practices used in power, structural and } \\
\text { technical systems }\end{array}$ & .00 \\
\hline & Basic plant nutrition & .00 \\
\hline & Basic soil science & 15.38 \\
\hline & Bio-security in the animal industry & .00 \\
\hline & Breeds of livestock & .00 \\
\hline & Common and scientific names of major animal species & .00 \\
\hline & Common types of feedstuffs & .00 \\
\hline & $\begin{array}{l}\text { Common weights and measures in the food products } \\
\text { and processing industry }\end{array}$ & .00 \\
\hline & Compare and contrast various food labels & .00 \\
\hline & Conduct a food preservation experiment. & .00 \\
\hline
\end{tabular}


Table Appendix 5

Percent of Respondents Using Particular Delivery Method for Each Content Skill Sets

\begin{tabular}{|c|c|c|}
\hline Method & Content Skill Set & Mean \\
\hline & Conduct soil sampling and testing & 15.38 \\
\hline & Construct a project using hand tools & .00 \\
\hline & $\begin{array}{l}\text { Convert decimals to percentages and percentages to } \\
\text { decimals }\end{array}$ & .00 \\
\hline & Convert fractions to decimal and decimals to fractions & .00 \\
\hline & Create a plan for their own agricultural enterprises & .00 \\
\hline & Create an advertisement for an agricultural product & 3.85 \\
\hline & $\begin{array}{l}\text { Debate the issues associated with animal welfare and } \\
\text { animal rights }\end{array}$ & .00 \\
\hline & Debate the issues associated with biotechnology & .00 \\
\hline & $\begin{array}{l}\text { Diagram a typical animal cell and identify the } \\
\text { organelles }\end{array}$ & .00 \\
\hline & $\begin{array}{l}\text { Diagram a typical plant cell and identify plant cell } \\
\text { organelles and their functions }\end{array}$ & .00 \\
\hline & Ecosystems & .00 \\
\hline & Effects of animal agriculture on the environment & .00 \\
\hline & $\begin{array}{l}\text { Facilities needed to housed and produce animal species } \\
\text { safely and efficiently }\end{array}$ & .00 \\
\hline & $\begin{array}{l}\text { Foods derived from meat, egg, poultry, fish and dairy } \\
\text { products }\end{array}$ & .00 \\
\hline & Functions of plant parts & 3.85 \\
\hline & $\begin{array}{l}\text { Identify agriculturally important plants by common } \\
\text { names }\end{array}$ & 7.69 \\
\hline & Identify alternative energy sources & .00 \\
\hline & Identify healthy ecosystem characteristics & 3.85 \\
\hline
\end{tabular}


Table Appendix 5

Percent of Respondents Using Particular Delivery Method for Each Content Skill Sets

\begin{tabular}{|c|c|c|}
\hline Method & Content Skill Set & Mean \\
\hline & Identify nonrenewable resources & .00 \\
\hline & Identify renewable resources & 3.85 \\
\hline & Identify the components and functions of plant roots & .00 \\
\hline & $\begin{array}{l}\text { Identify the components and the functions of plant } \\
\text { flowers }\end{array}$ & .00 \\
\hline & $\begin{array}{l}\text { Identify the components and the functions of plant } \\
\text { leaves }\end{array}$ & .00 \\
\hline & $\begin{array}{l}\text { Identify the components and the functions of plant } \\
\text { stems }\end{array}$ & .00 \\
\hline & $\begin{array}{l}\text { Interpret soil results to determine fertilizer application } \\
\text { needs }\end{array}$ & 3.85 \\
\hline & Livestock terminology (steer, heifer, barrow, gilt, etc.) & .00 \\
\hline & Methods of food preservations & .00 \\
\hline & $\begin{array}{l}\text { Methods of marketing agricultural commodities, } \\
\text { products and services in domestic and international } \\
\text { markets }\end{array}$ & .00 \\
\hline & Natural resources & 3.85 \\
\hline & Nonrenewable resources & .00 \\
\hline & Parts of a plant & .00 \\
\hline & Perform a basic health exam on a live animal & .00 \\
\hline & $\begin{array}{l}\text { Plant physiology - photosynthesis, reproduction, } \\
\text { respiration, transpiration }\end{array}$ & .00 \\
\hline & Practice administering injections & .00 \\
\hline & $\begin{array}{l}\text { Produce a food product (cheese, sausage, sauerkraut, } \\
\text { etc.) }\end{array}$ & .00 \\
\hline
\end{tabular}


Table Appendix 5

Percent of Respondents Using Particular Delivery Method for Each Content Skill Sets

\begin{tabular}{|c|c|c|}
\hline Method & Content Skill Set & Mean \\
\hline & Products derived from fruits and vegetables & .00 \\
\hline & Products derived from grains, legumes and oilseeds & .00 \\
\hline & Properly and safely used hand tools & .00 \\
\hline & Quality and yield grades of food products & .00 \\
\hline & Recite the FFA Creed & .00 \\
\hline & Recite the FFA motto & .00 \\
\hline & Renewable resources & .00 \\
\hline & $\begin{array}{l}\text { Research current agricultural products impacted by } \\
\text { biotechnology practices }\end{array}$ & .00 \\
\hline & $\begin{array}{l}\text { Research local supply and demand of agricultural } \\
\text { products }\end{array}$ & .00 \\
\hline & $\begin{array}{l}\text { Research the important dates and events in the history } \\
\text { of FFA and Agricultural Education }\end{array}$ & .00 \\
\hline & Return on investment & 3.85 \\
\hline & $\begin{array}{l}\text { Students will demonstrate knowledge of FFA history, } \\
\text { Code of Ethics and Official Dress }\end{array}$ & .00 \\
\hline & Supervised Agricultural Experience Program (SAE) & 11.54 \\
\hline & $\begin{array}{l}\text { The basic hand tools and their proper used in an } \\
\text { agricultural setting }\end{array}$ & .00 \\
\hline & The Four Ps (product, place, price and promotion) & .00 \\
\hline & The history of agriculture innovation & .00 \\
\hline & The history of the animal processing industry & .00 \\
\hline & The importance of food labeling to the consumer & .00 \\
\hline
\end{tabular}


Table Appendix 5

Percent of Respondents Using Particular Delivery Method for Each Content Skill Sets

\begin{tabular}{|c|c|c|}
\hline Method & Content Skill Set & Mean \\
\hline & $\begin{array}{l}\text { The major agriculture inventions and their impact on } \\
\text { the industry. }\end{array}$ & .00 \\
\hline & $\begin{array}{l}\text { The origin, significance, distribution and domestication } \\
\text { of animal systems }\end{array}$ & .00 \\
\hline & Types of agribusiness ownership & 3.85 \\
\hline & Units of weight, volume, and temperature & .00 \\
\hline & $\begin{array}{l}\text { Used a ruler, a metric ruler, and a measuring tape to } \\
\text { measure }\end{array}$ & .00 \\
\hline & Used agricultural related technology and equipment & .00 \\
\hline \multirow[t]{12}{*}{ Forestry } & $\begin{array}{l}\text { Add, subtract, multiply, and divide decimals, with and } \\
\text { without a calculator }\end{array}$ & .00 \\
\hline & Add, subtract, multiply, and divide fractions & .00 \\
\hline & $\begin{array}{l}\text { Add, subtract, multiply, and divide whole numbers, } \\
\text { with and without a calculator }\end{array}$ & .00 \\
\hline & Agricultural biotechnology & .00 \\
\hline & Animal cells & .00 \\
\hline & Animal health disorders & .00 \\
\hline & Animal welfare and animal rights & .00 \\
\hline & Applications of biotechnology in agriculture & .00 \\
\hline & Basic anatomy of animals & .00 \\
\hline & $\begin{array}{l}\text { Basic finance - personal inventory, net worth, income, } \\
\text { expense }\end{array}$ & 3.85 \\
\hline & $\begin{array}{l}\text { Basic math practices used in power, structural and } \\
\text { technical systems }\end{array}$ & 3.85 \\
\hline & Basic plant nutrition & .00 \\
\hline
\end{tabular}


Table Appendix 5

Percent of Respondents Using Particular Delivery Method for Each Content Skill Sets

\begin{tabular}{|c|c|c|}
\hline Method & Content Skill Set & Mean \\
\hline & Basic soil science & .00 \\
\hline & Bio-security in the animal industry & .00 \\
\hline & Breeds of livestock & .00 \\
\hline & Common and scientific names of major animal species & .00 \\
\hline & Common types of feedstuffs & .00 \\
\hline & $\begin{array}{l}\text { Common weights and measures in the food products } \\
\text { and processing industry }\end{array}$ & .00 \\
\hline & Compare and contrast various food labels & .00 \\
\hline & Conduct a food preservation experiment. & .00 \\
\hline & Conduct soil sampling and testing & .00 \\
\hline & Construct a project using hand tools & 3.85 \\
\hline & $\begin{array}{l}\text { Convert decimals to percentages and percentages to } \\
\text { decimals }\end{array}$ & .00 \\
\hline & Convert fractions to decimal and decimals to fractions & .00 \\
\hline & Create a plan for their own agricultural enterprises & .00 \\
\hline & Create an advertisement for an agricultural product & 3.85 \\
\hline & $\begin{array}{l}\text { Debate the issues associated with animal welfare and } \\
\text { animal rights }\end{array}$ & .00 \\
\hline & Debate the issues associated with biotechnology & .00 \\
\hline & $\begin{array}{l}\text { Diagram a typical animal cell and identify the } \\
\text { organelles }\end{array}$ & .00 \\
\hline & $\begin{array}{l}\text { Diagram a typical plant cell and identify plant cell } \\
\text { organelles and their functions }\end{array}$ & .00 \\
\hline & Ecosystems & .00 \\
\hline
\end{tabular}


Table Appendix 5

Percent of Respondents Using Particular Delivery Method for Each Content Skill Sets

\begin{tabular}{|c|c|c|}
\hline Method & Content Skill Set & Mean \\
\hline & Effects of animal agriculture on the environment & .00 \\
\hline & $\begin{array}{l}\text { Facilities needed to housed and produce animal species } \\
\text { safely and efficiently }\end{array}$ & .00 \\
\hline & $\begin{array}{l}\text { Foods derived from meat, egg, poultry, fish and dairy } \\
\text { products }\end{array}$ & .00 \\
\hline & Functions of plant parts & 3.85 \\
\hline & $\begin{array}{l}\text { Identify agriculturally important plants by common } \\
\text { names }\end{array}$ & 3.85 \\
\hline & Identify alternative energy sources & .00 \\
\hline & Identify healthy ecosystem characteristics & 3.85 \\
\hline & Identify nonrenewable resources & .00 \\
\hline & Identify renewable resources & 3.85 \\
\hline & Identify the components and functions of plant roots & .00 \\
\hline & $\begin{array}{l}\text { Identify the components and the functions of plant } \\
\text { flowers }\end{array}$ & 3.85 \\
\hline & $\begin{array}{l}\text { Identify the components and the functions of plant } \\
\text { leaves }\end{array}$ & 3.85 \\
\hline & $\begin{array}{l}\text { Identify the components and the functions of plant } \\
\text { stems }\end{array}$ & .00 \\
\hline & $\begin{array}{l}\text { Interpret soil results to determine fertilizer application } \\
\text { needs }\end{array}$ & .00 \\
\hline & Livestock terminology (steer, heifer, barrow, gilt, etc.) & .00 \\
\hline & Methods of food preservations & .00 \\
\hline & $\begin{array}{l}\text { Methods of marketing agricultural commodities, } \\
\text { products and services in domestic and international } \\
\text { markets }\end{array}$ & .00 \\
\hline
\end{tabular}


Table Appendix 5

Percent of Respondents Using Particular Delivery Method for Each Content Skill Sets

\begin{tabular}{|c|c|c|}
\hline Method & Content Skill Set & Mean \\
\hline & Natural resources & 3.85 \\
\hline & Nonrenewable resources & .00 \\
\hline & Parts of a plant & 3.85 \\
\hline & Perform a basic health exam on a live animal & .00 \\
\hline & $\begin{array}{l}\text { Plant physiology - photosynthesis, reproduction, } \\
\text { respiration, transpiration }\end{array}$ & .00 \\
\hline & Practice administering injections & .00 \\
\hline & $\begin{array}{l}\text { Produce a food product (cheese, sausage, sauerkraut, } \\
\text { etc.) }\end{array}$ & .00 \\
\hline & Products derived from fruits and vegetables & .00 \\
\hline & Products derived from grains, legumes and oilseeds & .00 \\
\hline & Properly and safely used hand tools & 3.85 \\
\hline & Quality and yield grades of food products & .00 \\
\hline & Recite the FFA Creed & .00 \\
\hline & Recite the FFA motto & .00 \\
\hline & Renewable resources & 3.85 \\
\hline & $\begin{array}{l}\text { Research current agricultural products impacted by } \\
\text { biotechnology practices }\end{array}$ & .00 \\
\hline & $\begin{array}{l}\text { Research local supply and demand of agricultural } \\
\text { products }\end{array}$ & .00 \\
\hline & $\begin{array}{l}\text { Research the important dates and events in the history } \\
\text { of FFA and Agricultural Education }\end{array}$ & .00 \\
\hline & Return on investment & 3.85 \\
\hline
\end{tabular}


Table Appendix 5

Percent of Respondents Using Particular Delivery Method for Each Content Skill Sets

\begin{tabular}{|c|c|c|}
\hline Method & Content Skill Set & Mean \\
\hline & $\begin{array}{l}\text { Students will demonstrate knowledge of FFA history, } \\
\text { Code of Ethics and Official Dress }\end{array}$ & .00 \\
\hline & Supervised Agricultural Experience Program (SAE) & 7.69 \\
\hline & $\begin{array}{l}\text { The basic hand tools and their proper used in an } \\
\text { agricultural setting }\end{array}$ & 3.85 \\
\hline & The Four Ps (product, place, price and promotion) & .00 \\
\hline & The history of agriculture innovation & .00 \\
\hline & The history of the animal processing industry & .00 \\
\hline & The importance of food labeling to the consumer & .00 \\
\hline & $\begin{array}{l}\text { The major agriculture inventions and their impact on } \\
\text { the industry. }\end{array}$ & .00 \\
\hline & $\begin{array}{l}\text { The origin, significance, distribution and domestication } \\
\text { of animal systems }\end{array}$ & .00 \\
\hline & Types of agribusiness ownership & 7.69 \\
\hline & Units of weight, volume, and temperature & .00 \\
\hline & $\begin{array}{l}\text { Used a ruler, a metric ruler, and a measuring tape to } \\
\text { measure }\end{array}$ & 3.85 \\
\hline & Used agricultural related technology and equipment & .00 \\
\hline \multirow[t]{5}{*}{ Other } & $\begin{array}{l}\text { Add, subtract, multiply, and divide decimals, with and } \\
\text { without a calculator }\end{array}$ & .00 \\
\hline & Add, subtract, multiply, and divide fractions & .00 \\
\hline & $\begin{array}{l}\text { Add, subtract, multiply, and divide whole numbers, } \\
\text { with and without a calculator }\end{array}$ & .00 \\
\hline & Agricultural biotechnology & 3.85 \\
\hline & Animal cells & .00 \\
\hline
\end{tabular}


Table Appendix 5

Percent of Respondents Using Particular Delivery Method for Each Content Skill Sets

\begin{tabular}{|c|c|c|}
\hline Method & Content Skill Set & Mean \\
\hline & Animal health disorders & .00 \\
\hline & Animal welfare and animal rights & .00 \\
\hline & Applications of biotechnology in agriculture & .00 \\
\hline & Basic anatomy of animals & .00 \\
\hline & $\begin{array}{l}\text { Basic finance - personal inventory, net worth, income, } \\
\text { expense }\end{array}$ & 11.54 \\
\hline & $\begin{array}{l}\text { Basic math practices used in power, structural and } \\
\text { technical systems }\end{array}$ & .00 \\
\hline & Basic plant nutrition & .00 \\
\hline & Basic soil science & .00 \\
\hline & Bio-security in the animal industry & 3.85 \\
\hline & Breeds of livestock & .00 \\
\hline & Common and scientific names of major animal species & .00 \\
\hline & Common types of feedstuffs & .00 \\
\hline & $\begin{array}{l}\text { Common weights and measures in the food products } \\
\text { and processing industry }\end{array}$ & 3.85 \\
\hline & Compare and contrast various food labels & 3.85 \\
\hline & Conduct a food preservation experiment. & 3.85 \\
\hline & Conduct soil sampling and testing & .00 \\
\hline & Construct a project using hand tools & .00 \\
\hline & $\begin{array}{l}\text { Convert decimals to percentages and percentages to } \\
\text { decimals }\end{array}$ & .00 \\
\hline & Convert fractions to decimal and decimals to fractions & .00 \\
\hline
\end{tabular}


Table Appendix 5

Percent of Respondents Using Particular Delivery Method for Each Content Skill Sets

\begin{tabular}{|c|c|c|}
\hline Method & Content Skill Set & Mean \\
\hline & Create a plan for their own agricultural enterprises & 7.69 \\
\hline & Create an advertisement for an agricultural product & 7.69 \\
\hline & $\begin{array}{l}\text { Debate the issues associated with animal welfare and } \\
\text { animal rights }\end{array}$ & .00 \\
\hline & Debate the issues associated with biotechnology & .00 \\
\hline & $\begin{array}{l}\text { Diagram a typical animal cell and identify the } \\
\text { organelles }\end{array}$ & .00 \\
\hline & $\begin{array}{l}\text { Diagram a typical plant cell and identify plant cell } \\
\text { organelles and their functions }\end{array}$ & .00 \\
\hline & Ecosystems & .00 \\
\hline & Effects of animal agriculture on the environment & .00 \\
\hline & $\begin{array}{l}\text { Facilities needed to housed and produce animal species } \\
\text { safely and efficiently }\end{array}$ & .00 \\
\hline & $\begin{array}{l}\text { Foods derived from meat, egg, poultry, fish and dairy } \\
\text { products }\end{array}$ & 3.85 \\
\hline & Functions of plant parts & .00 \\
\hline & $\begin{array}{l}\text { Identify agriculturally important plants by common } \\
\text { names }\end{array}$ & .00 \\
\hline & Identify alternative energy sources & .00 \\
\hline & Identify healthy ecosystem characteristics & .00 \\
\hline & Identify nonrenewable resources & .00 \\
\hline & Identify renewable resources & .00 \\
\hline & Identify the components and functions of plant roots & .00 \\
\hline & $\begin{array}{l}\text { Identify the components and the functions of plant } \\
\text { flowers }\end{array}$ & .00 \\
\hline
\end{tabular}


Table Appendix 5

Percent of Respondents Using Particular Delivery Method for Each Content Skill Sets

\begin{tabular}{|c|c|c|}
\hline Method & Content Skill Set & Mean \\
\hline & $\begin{array}{l}\text { Identify the components and the functions of plant } \\
\text { leaves }\end{array}$ & .00 \\
\hline & $\begin{array}{l}\text { Identify the components and the functions of plant } \\
\text { stems }\end{array}$ & .00 \\
\hline & $\begin{array}{l}\text { Interpret soil results to determine fertilizer application } \\
\text { needs }\end{array}$ & .00 \\
\hline & Livestock terminology (steer, heifer, barrow, gilt, etc.) & .00 \\
\hline & Methods of food preservations & 3.85 \\
\hline & $\begin{array}{l}\text { Methods of marketing agricultural commodities, } \\
\text { products and services in domestic and international } \\
\text { markets }\end{array}$ & 3.85 \\
\hline & Natural resources & .00 \\
\hline & Nonrenewable resources & .00 \\
\hline & Parts of a plant & .00 \\
\hline & Perform a basic health exam on a live animal & 3.85 \\
\hline & $\begin{array}{l}\text { Plant physiology - photosynthesis, reproduction, } \\
\text { respiration, transpiration }\end{array}$ & .00 \\
\hline & Practice administering injections & 3.85 \\
\hline & $\begin{array}{l}\text { Produce a food product (cheese, sausage, sauerkraut, } \\
\text { etc.) }\end{array}$ & 3.85 \\
\hline & Products derived from fruits and vegetables & 3.85 \\
\hline & Products derived from grains, legumes and oilseeds & 3.85 \\
\hline & Properly and safely used hand tools & .00 \\
\hline & Quality and yield grades of food products & 3.85 \\
\hline & Recite the FFA Creed & .00 \\
\hline
\end{tabular}


Table Appendix 5

Percent of Respondents Using Particular Delivery Method for Each Content Skill Sets

\begin{tabular}{|c|c|c|}
\hline Method & Content Skill Set & Mean \\
\hline & Recite the FFA motto & .00 \\
\hline & Renewable resources & .00 \\
\hline & $\begin{array}{l}\text { Research current agricultural products impacted by } \\
\text { biotechnology practices }\end{array}$ & .00 \\
\hline & $\begin{array}{l}\text { Research local supply and demand of agricultural } \\
\text { products }\end{array}$ & 3.85 \\
\hline & $\begin{array}{l}\text { Research the important dates and events in the history } \\
\text { of FFA and Agricultural Education }\end{array}$ & .00 \\
\hline & Return on investment & 3.85 \\
\hline & $\begin{array}{l}\text { Students will demonstrate knowledge of FFA history, } \\
\text { Code of Ethics and Official Dress }\end{array}$ & 3.85 \\
\hline & Supervised Agricultural Experience Program (SAE) & 15.38 \\
\hline & $\begin{array}{l}\text { The basic hand tools and their proper used in an } \\
\text { agricultural setting }\end{array}$ & .00 \\
\hline & The Four Ps (product, place, price and promotion) & 3.85 \\
\hline & The history of agriculture innovation & .00 \\
\hline & The history of the animal processing industry & 3.85 \\
\hline & The importance of food labeling to the consumer & 3.85 \\
\hline & $\begin{array}{l}\text { The major agriculture inventions and their impact on } \\
\text { the industry. }\end{array}$ & .00 \\
\hline & $\begin{array}{l}\text { The origin, significance, distribution and domestication } \\
\text { of animal systems }\end{array}$ & .00 \\
\hline & Types of agribusiness ownership & 11.54 \\
\hline & Units of weight, volume, and temperature & .00 \\
\hline
\end{tabular}


Table Appendix 5

Percent of Respondents Using Particular Delivery Method for Each Content Skill Sets

\begin{tabular}{|c|c|c|}
\hline Method & Content Skill Set & Mean \\
\hline & $\begin{array}{l}\text { Used a ruler, a metric ruler, and a measuring tape to } \\
\text { measure }\end{array}$ & .00 \\
\hline & Used agricultural related technology and equipment & .00 \\
\hline \multirow[t]{17}{*}{$\begin{array}{l}\text { Library computer } \\
\text { lab }\end{array}$} & $\begin{array}{l}\text { Add, subtract, multiply, and divide decimals, with and } \\
\text { without a calculator }\end{array}$ & .00 \\
\hline & Add, subtract, multiply, and divide fractions & .00 \\
\hline & $\begin{array}{l}\text { Add, subtract, multiply, and divide whole numbers, } \\
\text { with and without a calculator }\end{array}$ & .00 \\
\hline & Agricultural biotechnology & 15.38 \\
\hline & Animal cells & 3.85 \\
\hline & Animal health disorders & 19.23 \\
\hline & Animal welfare and animal rights & 3.85 \\
\hline & Applications of biotechnology in agriculture & 11.54 \\
\hline & Basic anatomy of animals & .00 \\
\hline & $\begin{array}{l}\text { Basic finance - personal inventory, net worth, income, } \\
\text { expense }\end{array}$ & 42.31 \\
\hline & $\begin{array}{l}\text { Basic math practices used in power, structural and } \\
\text { technical systems }\end{array}$ & 3.85 \\
\hline & Basic plant nutrition & .00 \\
\hline & Basic soil science & .00 \\
\hline & Bio-security in the animal industry & 7.69 \\
\hline & Breeds of livestock & 26.92 \\
\hline & Common and scientific names of major animal species & 11.54 \\
\hline & Common types of feedstuffs & 7.69 \\
\hline
\end{tabular}


Table Appendix 5

Percent of Respondents Using Particular Delivery Method for Each Content Skill Sets

\begin{tabular}{|c|c|c|}
\hline Method & Content Skill Set & Mean \\
\hline & $\begin{array}{l}\text { Common weights and measures in the food products } \\
\text { and processing industry }\end{array}$ & 3.85 \\
\hline & Compare and contrast various food labels & 3.85 \\
\hline & Conduct a food preservation experiment. & .00 \\
\hline & Conduct soil sampling and testing & .00 \\
\hline & Construct a project using hand tools & .00 \\
\hline & $\begin{array}{l}\text { Convert decimals to percentages and percentages to } \\
\text { decimals }\end{array}$ & .00 \\
\hline & Convert fractions to decimal and decimals to fractions & .00 \\
\hline & Create a plan for their own agricultural enterprises & 42.31 \\
\hline & Create an advertisement for an agricultural product & 34.62 \\
\hline & $\begin{array}{l}\text { Debate the issues associated with animal welfare and } \\
\text { animal rights }\end{array}$ & 11.54 \\
\hline & Debate the issues associated with biotechnology & 3.85 \\
\hline & $\begin{array}{l}\text { Diagram a typical animal cell and identify the } \\
\text { organelles }\end{array}$ & 3.85 \\
\hline & $\begin{array}{l}\text { Diagram a typical plant cell and identify plant cell } \\
\text { organelles and their functions }\end{array}$ & 3.85 \\
\hline & Ecosystems & 7.69 \\
\hline & Effects of animal agriculture on the environment & .00 \\
\hline & $\begin{array}{l}\text { Facilities needed to housed and produce animal species } \\
\text { safely and efficiently }\end{array}$ & 3.85 \\
\hline & $\begin{array}{l}\text { Foods derived from meat, egg, poultry, fish and dairy } \\
\text { products }\end{array}$ & .00 \\
\hline & Functions of plant parts & .00 \\
\hline
\end{tabular}


Table Appendix 5

Percent of Respondents Using Particular Delivery Method for Each Content Skill Sets

\begin{tabular}{|c|c|c|}
\hline Method & Content Skill Set & Mean \\
\hline & $\begin{array}{l}\text { Identify agriculturally important plants by common } \\
\text { names }\end{array}$ & 11.54 \\
\hline & Identify alternative energy sources & 7.69 \\
\hline & Identify healthy ecosystem characteristics & 7.69 \\
\hline & Identify nonrenewable resources & 11.54 \\
\hline & Identify renewable resources & 3.85 \\
\hline & Identify the components and functions of plant roots & .00 \\
\hline & $\begin{array}{l}\text { Identify the components and the functions of plant } \\
\text { flowers }\end{array}$ & .00 \\
\hline & $\begin{array}{l}\text { Identify the components and the functions of plant } \\
\text { leaves }\end{array}$ & .00 \\
\hline & $\begin{array}{l}\text { Identify the components and the functions of plant } \\
\text { stems }\end{array}$ & .00 \\
\hline & $\begin{array}{l}\text { Interpret soil results to determine fertilizer application } \\
\text { needs }\end{array}$ & 3.85 \\
\hline & Livestock terminology (steer, heifer, barrow, gilt, etc.) & 3.85 \\
\hline & Methods of food preservations & .00 \\
\hline & $\begin{array}{l}\text { Methods of marketing agricultural commodities, } \\
\text { products and services in domestic and international } \\
\text { markets }\end{array}$ & 26.92 \\
\hline & Natural resources & 11.54 \\
\hline & Nonrenewable resources & 11.54 \\
\hline & Parts of a plant & .00 \\
\hline & Perform a basic health exam on a live animal & 3.85 \\
\hline
\end{tabular}


Table Appendix 5

Percent of Respondents Using Particular Delivery Method for Each Content Skill Sets

\begin{tabular}{|c|c|c|}
\hline Method & Content Skill Set & Mean \\
\hline & $\begin{array}{l}\text { Plant physiology - photosynthesis, reproduction, } \\
\text { respiration, transpiration }\end{array}$ & .00 \\
\hline & Practice administering injections & .00 \\
\hline & $\begin{array}{l}\text { Produce a food product (cheese, sausage, sauerkraut, } \\
\text { etc.) }\end{array}$ & .00 \\
\hline & Products derived from fruits and vegetables & 3.85 \\
\hline & Products derived from grains, legumes and oilseeds & .00 \\
\hline & Properly and safely used hand tools & .00 \\
\hline & Quality and yield grades of food products & 3.85 \\
\hline & Recite the FFA Creed & 3.85 \\
\hline & Recite the FFA motto & 3.85 \\
\hline & Renewable resources & 3.85 \\
\hline & $\begin{array}{l}\text { Research current agricultural products impacted by } \\
\text { biotechnology practices }\end{array}$ & 23.08 \\
\hline & $\begin{array}{l}\text { Research local supply and demand of agricultural } \\
\text { products }\end{array}$ & 26.92 \\
\hline & $\begin{array}{l}\text { Research the important dates and events in the history } \\
\text { of FFA and Agricultural Education }\end{array}$ & 11.54 \\
\hline & Return on investment & 23.08 \\
\hline & $\begin{array}{l}\text { Students will demonstrate knowledge of FFA history, } \\
\text { Code of Ethics and Official Dress }\end{array}$ & 3.85 \\
\hline & Supervised Agricultural Experience Program (SAE) & 46.15 \\
\hline & $\begin{array}{l}\text { The basic hand tools and their proper used in an } \\
\text { agricultural setting }\end{array}$ & .00 \\
\hline & The Four Ps (product, place, price and promotion) & 19.23 \\
\hline
\end{tabular}


Table Appendix 5

Percent of Respondents Using Particular Delivery Method for Each Content Skill Sets

\begin{tabular}{|c|c|c|}
\hline Method & Content Skill Set & Mean \\
\hline & The history of agriculture innovation & 11.54 \\
\hline & The history of the animal processing industry & .00 \\
\hline & The importance of food labeling to the consumer & .00 \\
\hline & $\begin{array}{l}\text { The major agriculture inventions and their impact on } \\
\text { the industry. }\end{array}$ & 11.54 \\
\hline & $\begin{array}{l}\text { The origin, significance, distribution and domestication } \\
\text { of animal systems }\end{array}$ & 7.69 \\
\hline & Types of agribusiness ownership & 30.77 \\
\hline & Units of weight, volume, and temperature & .00 \\
\hline & $\begin{array}{l}\text { Used a ruler, a metric ruler, and a measuring tape to } \\
\text { measure }\end{array}$ & .00 \\
\hline & Used agricultural related technology and equipment & 11.54 \\
\hline \multirow[t]{9}{*}{ Field Trip } & $\begin{array}{l}\text { Add, subtract, multiply, and divide decimals, with and } \\
\text { without a calculator }\end{array}$ & .00 \\
\hline & Add, subtract, multiply, and divide fractions & .00 \\
\hline & $\begin{array}{l}\text { Add, subtract, multiply, and divide whole numbers, } \\
\text { with and without a calculator }\end{array}$ & .00 \\
\hline & Agricultural biotechnology & .00 \\
\hline & Animal cells & .00 \\
\hline & Animal health disorders & .00 \\
\hline & Animal welfare and animal rights & 3.85 \\
\hline & Applications of biotechnology in agriculture & .00 \\
\hline & Basic anatomy of animals & 3.85 \\
\hline
\end{tabular}


Table Appendix 5

Percent of Respondents Using Particular Delivery Method for Each Content Skill Sets

\begin{tabular}{|c|c|c|}
\hline Method & Content Skill Set & Mean \\
\hline & $\begin{array}{l}\text { Basic finance - personal inventory, net worth, income, } \\
\text { expense }\end{array}$ & .00 \\
\hline & $\begin{array}{l}\text { Basic math practices used in power, structural and } \\
\text { technical systems }\end{array}$ & .00 \\
\hline & Basic plant nutrition & .00 \\
\hline & Basic soil science & .00 \\
\hline & Bio-security in the animal industry & .00 \\
\hline & Breeds of livestock & 7.69 \\
\hline & Common and scientific names of major animal species & 3.85 \\
\hline & Common types of feedstuffs & .00 \\
\hline & $\begin{array}{l}\text { Common weights and measures in the food products } \\
\text { and processing industry }\end{array}$ & .00 \\
\hline & Compare and contrast various food labels & .00 \\
\hline & Conduct a food preservation experiment. & .00 \\
\hline & Conduct soil sampling and testing & 7.69 \\
\hline & Construct a project using hand tools & .00 \\
\hline & $\begin{array}{l}\text { Convert decimals to percentages and percentages to } \\
\text { decimals }\end{array}$ & .00 \\
\hline & Convert fractions to decimal and decimals to fractions & .00 \\
\hline & Create a plan for their own agricultural enterprises & 7.69 \\
\hline & Create an advertisement for an agricultural product & .00 \\
\hline & $\begin{array}{l}\text { Debate the issues associated with animal welfare and } \\
\text { animal rights }\end{array}$ & .00 \\
\hline & Debate the issues associated with biotechnology & .00 \\
\hline
\end{tabular}


Table Appendix 5

Percent of Respondents Using Particular Delivery Method for Each Content Skill Sets

\begin{tabular}{|c|c|c|}
\hline Method & Content Skill Set & Mean \\
\hline & $\begin{array}{l}\text { Diagram a typical animal cell and identify the } \\
\text { organelles }\end{array}$ & .00 \\
\hline & $\begin{array}{l}\text { Diagram a typical plant cell and identify plant cell } \\
\text { organelles and their functions }\end{array}$ & .00 \\
\hline & Ecosystems & 3.85 \\
\hline & Effects of animal agriculture on the environment & .00 \\
\hline & $\begin{array}{l}\text { Facilities needed to housed and produce animal species } \\
\text { safely and efficiently }\end{array}$ & 15.38 \\
\hline & $\begin{array}{l}\text { Foods derived from meat, egg, poultry, fish and dairy } \\
\text { products }\end{array}$ & .00 \\
\hline & Functions of plant parts & .00 \\
\hline & $\begin{array}{l}\text { Identify agriculturally important plants by common } \\
\text { names }\end{array}$ & 3.85 \\
\hline & Identify alternative energy sources & .00 \\
\hline & Identify healthy ecosystem characteristics & .00 \\
\hline & Identify nonrenewable resources & .00 \\
\hline & Identify renewable resources & .00 \\
\hline & Identify the components and functions of plant roots & .00 \\
\hline & $\begin{array}{l}\text { Identify the components and the functions of plant } \\
\text { flowers }\end{array}$ & .00 \\
\hline & $\begin{array}{l}\text { Identify the components and the functions of plant } \\
\text { leaves }\end{array}$ & .00 \\
\hline & $\begin{array}{l}\text { Identify the components and the functions of plant } \\
\text { stems }\end{array}$ & .00 \\
\hline & $\begin{array}{l}\text { Interpret soil results to determine fertilizer application } \\
\text { needs }\end{array}$ & 3.85 \\
\hline
\end{tabular}


Table Appendix 5

Percent of Respondents Using Particular Delivery Method for Each Content Skill Sets

\begin{tabular}{|c|c|c|}
\hline Method & Content Skill Set & Mean \\
\hline & Livestock terminology (steer, heifer, barrow, gilt, etc.) & 3.85 \\
\hline & Methods of food preservations & .00 \\
\hline & $\begin{array}{l}\text { Methods of marketing agricultural commodities, } \\
\text { products and services in domestic and international } \\
\text { markets }\end{array}$ & 3.85 \\
\hline & Natural resources & .00 \\
\hline & Nonrenewable resources & .00 \\
\hline & Parts of a plant & .00 \\
\hline & Perform a basic health exam on a live animal & 7.69 \\
\hline & $\begin{array}{l}\text { Plant physiology - photosynthesis, reproduction, } \\
\text { respiration, transpiration }\end{array}$ & .00 \\
\hline & Practice administering injections & 3.85 \\
\hline & $\begin{array}{l}\text { Produce a food product (cheese, sausage, sauerkraut, } \\
\text { etc.) }\end{array}$ & .00 \\
\hline & Products derived from fruits and vegetables & .00 \\
\hline & Products derived from grains, legumes and oilseeds & .00 \\
\hline & Properly and safely used hand tools & .00 \\
\hline & Quality and yield grades of food products & .00 \\
\hline & Recite the FFA Creed & 3.85 \\
\hline & Recite the FFA motto & .00 \\
\hline & Renewable resources & .00 \\
\hline & $\begin{array}{l}\text { Research current agricultural products impacted by } \\
\text { biotechnology practices }\end{array}$ & .00 \\
\hline
\end{tabular}


Table Appendix 5

Percent of Respondents Using Particular Delivery Method for Each Content Skill Sets

\begin{tabular}{|c|c|c|}
\hline Method & Content Skill Set & Mean \\
\hline & $\begin{array}{l}\text { Research local supply and demand of agricultural } \\
\text { products }\end{array}$ & 3.85 \\
\hline & $\begin{array}{l}\text { Research the important dates and events in the history } \\
\text { of FFA and Agricultural Education }\end{array}$ & .00 \\
\hline & Return on investment & 7.69 \\
\hline & $\begin{array}{l}\text { Students will demonstrate knowledge of FFA history, } \\
\text { Code of Ethics and Official Dress }\end{array}$ & 3.85 \\
\hline & Supervised Agricultural Experience Program (SAE) & 19.23 \\
\hline & $\begin{array}{l}\text { The basic hand tools and their proper used in an } \\
\text { agricultural setting }\end{array}$ & .00 \\
\hline & The Four Ps (product, place, price and promotion) & .00 \\
\hline & The history of agriculture innovation & .00 \\
\hline & The history of the animal processing industry & .00 \\
\hline & The importance of food labeling to the consumer & .00 \\
\hline & $\begin{array}{l}\text { The major agriculture inventions and their impact on } \\
\text { the industry. }\end{array}$ & .00 \\
\hline & $\begin{array}{l}\text { The origin, significance, distribution and domestication } \\
\text { of animal systems }\end{array}$ & 7.69 \\
\hline & Types of agribusiness ownership & 11.54 \\
\hline & Units of weight, volume, and temperature & .00 \\
\hline & $\begin{array}{l}\text { Used a ruler, a metric ruler, and a measuring tape to } \\
\text { measure }\end{array}$ & .00 \\
\hline & Used agricultural related technology and equipment & 3.85 \\
\hline Do not Teach & $\begin{array}{l}\text { Add, subtract, multiply, and divide decimals, with and } \\
\text { without a calculator }\end{array}$ & 11.54 \\
\hline
\end{tabular}


Table Appendix 5

Percent of Respondents Using Particular Delivery Method for Each Content Skill Sets

\begin{tabular}{|c|c|c|}
\hline Method & Content Skill Set & Mean \\
\hline & Add, subtract, multiply, and divide fractions & 11.54 \\
\hline & $\begin{array}{l}\text { Add, subtract, multiply, and divide whole numbers, } \\
\text { with and without a calculator }\end{array}$ & 3.85 \\
\hline & Agricultural biotechnology & 7.69 \\
\hline & Animal cells & .00 \\
\hline & Animal health disorders & .00 \\
\hline & Animal welfare and animal rights & .00 \\
\hline & Applications of biotechnology in agriculture & 7.69 \\
\hline & Basic anatomy of animals & .00 \\
\hline & $\begin{array}{l}\text { Basic finance - personal inventory, net worth, income, } \\
\text { expense }\end{array}$ & .00 \\
\hline & $\begin{array}{l}\text { Basic math practices used in power, structural and } \\
\text { technical systems }\end{array}$ & 3.85 \\
\hline & Basic plant nutrition & .00 \\
\hline & Basic soil science & .00 \\
\hline & Bio-security in the animal industry & .00 \\
\hline & Breeds of livestock & .00 \\
\hline & Common and scientific names of major animal species & 3.85 \\
\hline & Common types of feedstuffs & .00 \\
\hline & $\begin{array}{l}\text { Common weights and measures in the food products } \\
\text { and processing industry }\end{array}$ & 11.54 \\
\hline & Compare and contrast various food labels & 11.54 \\
\hline & Conduct a food preservation experiment. & 30.77 \\
\hline
\end{tabular}


Table Appendix 5

Percent of Respondents Using Particular Delivery Method for Each Content Skill Sets

\begin{tabular}{|c|c|c|}
\hline Method & Content Skill Set & Mean \\
\hline & Conduct soil sampling and testing & .00 \\
\hline & Construct a project using hand tools & 11.54 \\
\hline & $\begin{array}{l}\text { Convert decimals to percentages and percentages to } \\
\text { decimals }\end{array}$ & 11.54 \\
\hline & Convert fractions to decimal and decimals to fractions & 15.38 \\
\hline & Create a plan for their own agricultural enterprises & .00 \\
\hline & Create an advertisement for an agricultural product & .00 \\
\hline & $\begin{array}{l}\text { Debate the issues associated with animal welfare and } \\
\text { animal rights }\end{array}$ & 3.85 \\
\hline & Debate the issues associated with biotechnology & 7.69 \\
\hline & $\begin{array}{l}\text { Diagram a typical animal cell and identify the } \\
\text { organelles }\end{array}$ & 7.69 \\
\hline & $\begin{array}{l}\text { Diagram a typical plant cell and identify plant cell } \\
\text { organelles and their functions }\end{array}$ & .00 \\
\hline & Ecosystems & .00 \\
\hline & Effects of animal agriculture on the environment & .00 \\
\hline & $\begin{array}{l}\text { Facilities needed to housed and produce animal species } \\
\text { safely and efficiently }\end{array}$ & 3.85 \\
\hline & $\begin{array}{l}\text { Foods derived from meat, egg, poultry, fish and dairy } \\
\text { products }\end{array}$ & .00 \\
\hline & Functions of plant parts & .00 \\
\hline & $\begin{array}{l}\text { Identify agriculturally important plants by common } \\
\text { names }\end{array}$ & 3.85 \\
\hline & Identify alternative energy sources & 7.69 \\
\hline & Identify healthy ecosystem characteristics & 3.85 \\
\hline
\end{tabular}


Table Appendix 5

Percent of Respondents Using Particular Delivery Method for Each Content Skill Sets

\begin{tabular}{|c|c|c|}
\hline Method & Content Skill Set & Mean \\
\hline & Identify nonrenewable resources & 7.69 \\
\hline & Identify renewable resources & 3.85 \\
\hline & Identify the components and functions of plant roots & .00 \\
\hline & $\begin{array}{l}\text { Identify the components and the functions of plant } \\
\text { flowers }\end{array}$ & .00 \\
\hline & $\begin{array}{l}\text { Identify the components and the functions of plant } \\
\text { leaves }\end{array}$ & .00 \\
\hline & $\begin{array}{l}\text { Identify the components and the functions of plant } \\
\text { stems }\end{array}$ & .00 \\
\hline & $\begin{array}{l}\text { Interpret soil results to determine fertilizer application } \\
\text { needs }\end{array}$ & 3.85 \\
\hline & Livestock terminology (steer, heifer, barrow, gilt, etc.) & .00 \\
\hline & Methods of food preservations & 11.54 \\
\hline & $\begin{array}{l}\text { Methods of marketing agricultural commodities, } \\
\text { products and services in domestic and international } \\
\text { markets }\end{array}$ & 7.69 \\
\hline & Natural resources & .00 \\
\hline & Nonrenewable resources & 3.85 \\
\hline & Parts of a plant & .00 \\
\hline & Perform a basic health exam on a live animal & 23.08 \\
\hline & $\begin{array}{l}\text { Plant physiology - photosynthesis, reproduction, } \\
\text { respiration, transpiration }\end{array}$ & .00 \\
\hline & Practice administering injections & 15.38 \\
\hline & $\begin{array}{l}\text { Produce a food product (cheese, sausage, sauerkraut, } \\
\text { etc.) }\end{array}$ & 11.54 \\
\hline
\end{tabular}


Table Appendix 5

Percent of Respondents Using Particular Delivery Method for Each Content Skill Sets

\begin{tabular}{|c|c|c|}
\hline Method & Content Skill Set & Mean \\
\hline & Products derived from fruits and vegetables & 3.85 \\
\hline & Products derived from grains, legumes and oilseeds & 3.85 \\
\hline & Properly and safely used hand tools & 7.69 \\
\hline & Quality and yield grades of food products & 7.69 \\
\hline & Recite the FFA Creed & .00 \\
\hline & Recite the FFA motto & .00 \\
\hline & Renewable resources & 3.85 \\
\hline & $\begin{array}{l}\text { Research current agricultural products impacted by } \\
\text { biotechnology practices }\end{array}$ & 11.54 \\
\hline & $\begin{array}{l}\text { Research local supply and demand of agricultural } \\
\text { products }\end{array}$ & 11.54 \\
\hline & $\begin{array}{l}\text { Research the important dates and events in the history } \\
\text { of FFA and Agricultural Education }\end{array}$ & .00 \\
\hline & Return on investment & 3.85 \\
\hline & $\begin{array}{l}\text { Students will demonstrate knowledge of FFA history, } \\
\text { Code of Ethics and Official Dress }\end{array}$ & .00 \\
\hline & Supervised Agricultural Experience Program (SAE) & 3.85 \\
\hline & $\begin{array}{l}\text { The basic hand tools and their proper used in an } \\
\text { agricultural setting }\end{array}$ & 3.85 \\
\hline & The Four Ps (product, place, price and promotion) & 3.85 \\
\hline & The history of agriculture innovation & 3.85 \\
\hline & The history of the animal processing industry & 19.23 \\
\hline & The importance of food labeling to the consumer & 7.69 \\
\hline
\end{tabular}


Table Appendix 5

Percent of Respondents Using Particular Delivery Method for Each Content Skill Sets

\begin{tabular}{lc}
\hline Method & Mean \\
\hline $\begin{array}{l}\text { The major agriculture inventions and their impact on } \\
\text { the industry. }\end{array}$ & 3.85 \\
$\begin{array}{l}\text { The origin, significance, distribution and domestication } \\
\text { of animal systems }\end{array}$ & .00 \\
$\begin{array}{l}\text { Types of agribusiness ownership } \\
\text { Units of weight, volume, and temperature }\end{array}$ & 3.85 \\
$\begin{array}{l}\text { Used a ruler, a metric ruler, and a measuring tape to } \\
\text { measure }\end{array}$ & 3.85 \\
$\begin{array}{l}\text { Used agricultural related technology and equipment } \\
\end{array}$ & 7.69
\end{tabular}


APPENDIX F 
Table 86

Average Percent Each Method was Used to Teach the Skills in the Category.

\begin{tabular}{|c|c|c|}
\hline Area & Method & Mean \\
\hline \multirow[t]{16}{*}{ Agribusiness } & Project Based & 58.97 \\
\hline & Inquiry & 26.07 \\
\hline & Discussion & 43.59 \\
\hline & Demonstration & 14.53 \\
\hline & Lecture & 34.62 \\
\hline & Textbooks Handouts & 19.66 \\
\hline & Mechanics & 9.83 \\
\hline & Greenhouse & 27.35 \\
\hline & Meats & 11.96 \\
\hline & Biotechnology & 1.71 \\
\hline & Land & 2.99 \\
\hline & Forestry & 2.99 \\
\hline & Other & 7.69 \\
\hline & Library computer lab & 32.48 \\
\hline & Field Trip & 5.98 \\
\hline & Do not Teach & 3.85 \\
\hline \multirow[t]{7}{*}{ Animal Systems } & Project Based & 27.40 \\
\hline & Inquiry & 19.23 \\
\hline & Discussion & 29.09 \\
\hline & Demonstration & 10.10 \\
\hline & Lecture & 29.57 \\
\hline & Textbooks Handouts & 27.17 \\
\hline & Mechanics & .72 \\
\hline
\end{tabular}


Table 86

Average Percent Each Method was Used to Teach the Skills in the Category.

\begin{tabular}{|c|c|c|}
\hline Area & Method & Mean \\
\hline \multirow{23}{*}{$\begin{array}{l}\text { Agriculture } \\
\text { Innovations }\end{array}$} & Greenhouse & .00 \\
\hline & Meats & 3.61 \\
\hline & Biotechnology & .72 \\
\hline & Land & .00 \\
\hline & Forestry & .00 \\
\hline & Other & .72 \\
\hline & Library computer lab & 7.21 \\
\hline & Field Trip & 3.61 \\
\hline & Do not Teach & 3.61 \\
\hline & Project Based & 16.48 \\
\hline & Inquiry & 14.28 \\
\hline & Discussion & 35.17 \\
\hline & Demonstration & 2.75 \\
\hline & Lecture & 18.68 \\
\hline & Textbooks Handouts & 25.82 \\
\hline & Mechanics & 1.65 \\
\hline & Greenhouse & 2.75 \\
\hline & Meats & 1.65 \\
\hline & Biotechnology & 4.95 \\
\hline & Land & .00 \\
\hline & Forestry & .00 \\
\hline & Other & .55 \\
\hline & Library computer lab & 12.64 \\
\hline
\end{tabular}


Table 86

Average Percent Each Method was Used to Teach the Skills in the Category.

\begin{tabular}{|c|c|c|}
\hline Area & Method & Mean \\
\hline \multirow{14}{*}{$\begin{array}{l}\text { Food Products and } \\
\text { Processing }\end{array}$} & Field Trip & .55 \\
\hline & Do not Teach & 7.14 \\
\hline & Project Based & 18.18 \\
\hline & Inquiry & 10.84 \\
\hline & Discussion & 25.17 \\
\hline & Demonstration & 11.19 \\
\hline & Lecture & 27.97 \\
\hline & Textbooks Handouts & 18.18 \\
\hline & Mechanics & .00 \\
\hline & Greenhouse & 1.05 \\
\hline & Meats & 12.24 \\
\hline & Biotechnology & .00 \\
\hline & Land & .00 \\
\hline & Forestry & .00 \\
\hline \multirow{9}{*}{ Natural Resources } & Other & 3.85 \\
\hline & Library computer lab & 1.40 \\
\hline & Field Trip & .00 \\
\hline & Do not Teach & 10.84 \\
\hline & Project Based & 14.90 \\
\hline & Inquiry & 16.82 \\
\hline & Discussion & 39.42 \\
\hline & Demonstration & 1.93 \\
\hline & Lecture & 31.73 \\
\hline
\end{tabular}


Table 86

Average Percent Each Method was Used to Teach the Skills in the Category.

\begin{tabular}{|c|c|c|}
\hline Area & Method & Mean \\
\hline & Textbooks Handouts & 31.73 \\
\hline & Mechanics & .00 \\
\hline & Greenhouse & 1.44 \\
\hline & Meats & .00 \\
\hline & Biotechnology & .96 \\
\hline & Land & 1.44 \\
\hline & Forestry & 1.92 \\
\hline & Other & .00 \\
\hline & Library computer lab & 8.17 \\
\hline & Field Trip & .48 \\
\hline & Do not Teach & 3.85 \\
\hline \multirow[t]{12}{*}{ Plant Systems } & Project Based & 26.04 \\
\hline & Inquiry & 11.54 \\
\hline & Discussion & 27.22 \\
\hline & Demonstration & 8.28 \\
\hline & Lecture & 31.66 \\
\hline & Textbooks Handouts & 35.21 \\
\hline & Mechanics & .00 \\
\hline & Greenhouse & 28.99 \\
\hline & Meats & .00 \\
\hline & Biotechnology & 5.92 \\
\hline & Land & 3.55 \\
\hline & Forestry & 1.48 \\
\hline
\end{tabular}


Table 86

Average Percent Each Method was Used to Teach the Skills in the Category.

\begin{tabular}{|c|c|c|}
\hline Area & Method & Mean \\
\hline \multirow{18}{*}{$\begin{array}{l}\text { Power, Structural \& } \\
\text { Technical Systems }\end{array}$} & Other & .00 \\
\hline & Library computer lab & 1.48 \\
\hline & Field Trip & 1.18 \\
\hline & Do not Teach & .59 \\
\hline & Project Based & 17.13 \\
\hline & Inquiry & 11.54 \\
\hline & Discussion & 20.98 \\
\hline & Demonstration & 21.68 \\
\hline & Lecture & 20.63 \\
\hline & Textbooks Handouts & 23.43 \\
\hline & Mechanics & 24.83 \\
\hline & Greenhouse & 6.99 \\
\hline & Meats & 1.75 \\
\hline & Biotechnology & .35 \\
\hline & Land & .00 \\
\hline & Forestry & 1.75 \\
\hline & Other & .00 \\
\hline & Library computer lab & .35 \\
\hline \multirow{5}{*}{ Leadership } & Field Trip & .00 \\
\hline & Do not Teach & 8.74 \\
\hline & Project Based & 41.35 \\
\hline & Inquiry & 9.62 \\
\hline & Discussion & 31.73 \\
\hline
\end{tabular}


Table 86

Average Percent Each Method was Used to Teach the Skills in the Category.

\begin{tabular}{lc}
\hline Area & Mean \\
\hline Demonstration & 16.35 \\
Lecture & 32.69 \\
Textbooks Handouts & 25.00 \\
Mechanics & .00 \\
Greenhouse & .00 \\
Meats & .00 \\
Biotechnology & .00 \\
Land & .00 \\
Forestry & .00 \\
Other & .96 \\
Library computer lab & 5.77 \\
Field Trip & 1.92 \\
Do not Teach & .00 \\
\hline
\end{tabular}


VITA

\section{Education:}

May 10, 2019

Masters of Science in Agricultural and Extension Education

West Virginia University

2014

MS in Curriculum and Instruction in Science Education

West Virginia University

2012

Master's in Business Administration

Salem International University

1995

Bachelor of Science in Secondary Education in Environmental Science

California University of Pennsylvania

CASE Training (Curriculum for Agricultural Science Education)

2018

Research in Agriculture

On Line

2018

Biotechnology

Westminster, MD

2016

Animal Science

Pique, $\mathrm{OH}$

2015

Agriculture, Food, and Natural Resources

Lexington, $\mathrm{KY}$

\section{Teaching Experience:}

2014-present

Vocational Agriculture Teacher at Tygarts Valley Middle/High School

Courses taught include:

Introduction to Agriculture:

This course involved teaching the basic concepts of agriculture, including food science, nature resources, plant and animal science, soil science, agricultural mechanics, shop safety, the Supervised Agricultural Experience (SAE), and FFA. This course was replaced by the CASE Curriculum. 
CASE AFNR:

This course covers the concepts covered in Introduction to Agriculture but uses a more scientific approach with technology and more hands-on learning experiences.

Science of Agriculture:

This course involves more in-depth plant and animal science, biotechnology, basic welding skills and safety, small engine repair and maintenance, forest management, and wildlife management.

CASE Animal Science:

This course involves livestock breeds, history of the animal breeds, external body parts, internal body systems, safe animal handling and facilities, animal nutrition, animal health and diseases, meat cuts, value added products, animal products, ethical treatment of animals and the production of animal production manual.

Natural Resource Management:

This course involves government regulatory agencies, habitat, introduction to forest management, soil management and uses, wildlife management and uses, water management and uses, and the development of a management plan.

Fish and Wildlife Management:

This course involves the in-depth study of regulatory agencies, fish species identification, wildlife identification, specimen preservation, and habitat management.

Fundamentals of Agriculture Mechanics:

This course involves shop safety, electrical wiring of light switches, receptacles, light sockets, types and uses of different types of electrical wire, plumbing with basic tools, soldering of copper tubing, measuring, cutting, fitting of PVC pipe, galvanized pipe, black plastic water line, operating wood working equipment, oxygen-acetylene welding, brazing and cutting, ARC welding safety, plasma cutter safety and use, sketching and drawing, and blue print reading.

Farm Equipment Repair and Maintenance:

This course involves customer satisfaction, ordering parts, parts identification, reading service charts for various types of equipment, engine repair, general equipment repair and maintenance, and welding.

2018-Present

Adjunct Instructor at Blue Ridge Community and Technical College Courses taught:

Introduction to Cattle Production:

This course involves the basics of cattle production, selection of breeds, selecting bulls and heifers, calf management, pregnancy care, cattle health, cattle diseases, types of fencing for corrals, pens, chutes, handling facilities, safe handling of cattle, grazing management, animal anatomy (external and internal), cattle products, selection of dairy cattle, operation of a cattle facility (beef or dairy), development of a cattle production plan. 
Introduction to Farm Equipment:

This course involves selecting the proper type of tractor, hay, harvesting, planting equipment, electric motor selection, irrigation types and selection, shop safety, equipment safety, equipment maintenance, and equipment storage and shop design and usage. 